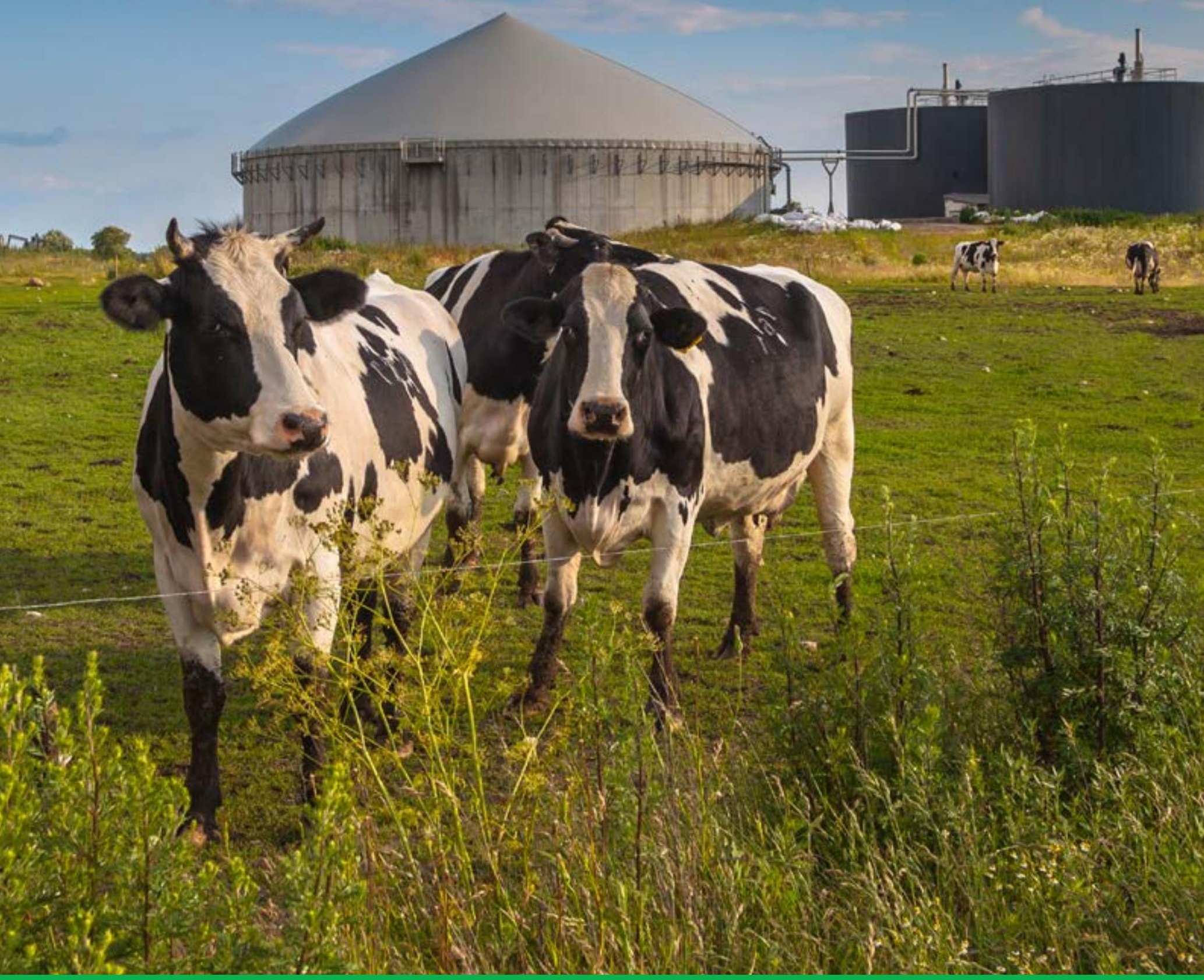

\title{
Risicobeoordeling van contaminanten in afval- en reststoffen bestemd voor gebruik als covergistingsmateriaal
}

P.A.I. Ehlert, H.J. van Wijnen, J. Struijs,

| wOt-technical report 70

T.A. van Dijk, L. van Schöll \& L.R.M. de Poorter 

Risicobeoordeling van contaminanten in afval- en reststoffen bestemd voor gebruik als covergistingsmateriaal 
Dit Technical report is gemaakt conform het Kwaliteitshandboek van de unit Wettelijke Onderzoekstaken Natuur \& Milieu.

De WOT Natuur \& Milieu voert wettelijke onderzoekstaken uit op het beleidsterrein natuur en milieu. Deze taken worden uitgevoerd om een wettelijke verantwoordelijkheid van de minister van Economische Zaken te ondersteunen. De WOT Natuur \& Milieu werkt aan producten van het Planbureau voor de Leefomgeving, zoals de Balans van de Leefomgeving en de Natuurverkenning. Verder brengen we voor het ministerie van Economische Zaken adviezen uit over (toelating van) meststoffen en bestrijdingsmiddelen, en zorgen we voor informatie voor Europese rapportageverplichtingen over biodiversiteit.

De reeks 'WOt-technical reports bevat onderzoeksresultaten van projecten die kennisorganisaties voor de unit Wettelijke Onderzoekstaken Natuur \& Milieu hebben uitgevoerd.

WOt-technical report 70 is het resultaat van een onderzoeksopdracht uitgevoerd onder de verantwoordelijkheid van de Commissie Deskundigen Meststoffenwet (CDM) en gefinancierd door het Ministerie van Economische Zaken (EZ).

Dit WOt-technisch report vervangt WOt-werkdocument 333 (2013) doordat een Engelstalig referaat en samenvatting zijn toegevoegd. 


\section{Risicobeoordeling van contaminanten in afval- en reststoffen bestemd voor gebruik als covergistingsmateriaal}

P.A.I. Ehlert, H.J. van Wijnen, J. Struijs, T.A. van Dijk, L. van Schöll \& L.R.M. de Poorter 


\section{Referaat}

Ehlert, P.A.I, H.J. van Wijnen, J. Struijs, T.A. van Dijk, L. van Schöll \& L.R.M. de Poorter (2016). Risicobeoordeling van contaminanten in afval- en reststoffen bestemd voor gebruik als covergistingsmateriaal. Wageningen, Wettelijke Onderzoekstaken Natuur \& Milieu, WUR. WOt-technical report 70 . 158 blz. 7 fig.; 19 tab, 38 ref.; 8 bijl.

Een beoordeling is uitgevoerd van 21 stoffen die door LTO-Noord en de Biogas Branche Organisatie (BBO) aangemeld zijn voor opname in bijlage Aa van de Uitvoeringsregeling Meststoffenwet. Op verzoek van het ministerie EZ zijn daar 6 stoffen aan toegevoegd $(21+6)$ en werden 119 eerder aangemelde stoffen herbeoordeeld in met verband wijziging van de keuze voor de samenstelling van dierlijke mest. De beoordeling betreft met name de milieuhygienische consequenties van het gebruik van covergistings-materialen en het resulterende digestaat na vergisting. De beoordeling van de zware metaal- en arseengehalten en de door de Meststoffenwet aangewezen organische microverontreinigingen volgt het Protocol Beoordeling Stoffen Meststoffenwet, versie 2.1. Expert judgement is toegepast in geval gegevens niet of niet volledig beschikbaar waren om dit protocol te kunnen toepassen. Criteria voor expert judgement zijn voor deze situatie opgesteld. Om de residuen van gewasbeschermingsmiddelen en biociden te beoordelen, zijn drie alternatieve systematieken opgesteld, mede gebaseerd op toepassing van expert judgement. Het na te streven beschermingsniveau bepaalt welke systematiek gebruikt zal gaan worden. De $21+6$ stoffen zijn beoordeeld volgens het protocol en opgestelde alternatieven. De toelating van covergistingsmaterialen in Vlaanderen, Denemarken en Duitsland is betrokken bij de beoordeling. Ten slotte worden aanbevelingen gedaan om te komen tot beleidsafwegingen en -keuzes inzake opgestelde alternatieven en tot een effectief protocol voor toelating van afval- en reststoffen als covergistingsmateriaal.

Trefwoorden: Biogas, covergistingsmateriaal, zware metalen, arseen, organische microverontreinigingen, residuen gewasbeschermingsmiddelen en biociden, protocol, Meststoffenwet, Uitvoeringsregeling.

\section{Abstract}

Ehlert, P.A.I, H.J. van Wijnen, J. Struijs, T.A. van Dijk, L. van Schöll \& L.R.M. de Poorter (2016). Risk assessment of contaminants in wastes and by-products to be used as co-digestion material. Statutory Research Tasks Unit for Nature \& Environment, WUR, Wageningen. WOt-technical report 70.158 p.; 7 figs; 19 tabs, 38 refs; 8 app.

A number of wastes and by-products were reviewed for their suitability as substrates for co-digestion with animal manure to produce biogas and a digestate for use as a fertiliser. The review included 21 substances proposed by LTO Noord (Dutch Farmers Union - Northern Netherlands) and Biogas Branche Organisatie (BBO, the Dutch Biogas Industry Association) for inclusion in Annex Aa of the Fertiliser Act. At the request of the Ministry of Economic Affairs a further 6 substances were added $(21+6)$. In addition, 119 substances were re-reviewed in connection with a change to the reference composition for animal manure. The review focused on the possible adverse environmental effects of using the digestate as a fertiliser and followed the protocol for assessing the value and risks of waste used as a fertiliser, version 2.1. The risk assessment included the inorganic contaminants $(\mathrm{Cd}, \mathrm{Cr}, \mathrm{Cu}$, $\mathrm{Hg}, \mathrm{Ni}, \mathrm{Pb}, \mathrm{Zn}, \mathrm{As}$ ) and organic contaminants (dioxine, PCBs, PAHs, mineral oil, residues of crop protection products) as required by the Fertiliser Act. For all the wastes and by-products, data on composition were collected from the literature and from analyses provided by stakeholders. Expert judgment was used where data were not available or were insufficient to conduct a risk assessment as prescribed by the protocol. Criteria for expert judgment were developed for such situations. Two alternative risk assessment methods were developed for the residues of pesticides and biocides, based partly on expert judgement. These methods were compared with the method prescribed by the protocol. These three methods reflect different policy judgements; the protection level set by policymakers will determine which method should be used. The $21+6$ substances were evaluated in accordance with the protocol and using the three methods for evaluating the residues of pesticides and biocides. The results were compared with registered co-digestion materials in Flanders, Denmark and Germany. Recommendations are given to support policy decisions on the choice of alternative risk assessment method to be used to permit the codigestion of wastes and by-products in biogas production that produce an agronomically and environmentally acceptable digestate for fertiliser use.

Keywords: Biogas, co-digestion material, heavy metals, arsenic, organic contaminants, residues of plant protection products and biocides, Fertiliser Act

Auteurs: P.A.I. Ehlert -Wageningen Environmental Research (Alterra); H. van Wijnen, J. Struijs en L.R.M. Poorter - RIVM T.A. van Dijk en L van Schöll - Nutriënten Management Instituut (NMI)

\section{(C) 2016 Wageningen}

Environmental Research (Alterra)

Postbus 47, 6700 AA Wageningen

Tel: (0317) 480700

e-mail: info.alterra@wur.nl

\section{Nutriënten Management Instituut NMI B.V.}

Postbus 250,6700 AG Wageningen

Tel: (088) 8761280

e-mail: nmi@nmi-agro.nl

\section{Rijksinstituut voor} Volksgezondheid \& Milieu (RIVM) P.O. Box 1, 3720 BA Bilthoven Tel: (030) 2749111 e-mail: info@rivm.nl

De reeks WOt-technical reports is een uitgave van de unit Wettelijke Onderzoekstaken Natuur \& Milieu, onderdeel van Wageningen University \& Research. Dit report is verkrijgbaar bij het secretariaat. De publicatie is ook te downloaden via www.wur.nl/wotnatuurenmilieu.

Wettelijke Onderzoekstaken Natuur \& Milieu, Postbus 47, 6700 AA Wageningen Tel: (0317) 4854 71; e-mail: info.wnm@wur.nl; Internet: www.wur.nl/wotnatuurenmilieu

Alle rechten voorbehouden. Niets uit deze uitgave mag worden verveelvoudigd en/of openbaar gemaakt door middel van druk, fotokopie, microfilm of op welke andere wijze ook zonder voorafgaande schriftelijke toestemming van de uitgever. De uitgever aanvaardt geen aansprakelijkheid voor eventuele schade voortvloeiend uit het gebruik van de resultaten van dit onderzoek of de toepassing van de adviezen. 


\section{Woord vooraf}

Biogasproductie uit afval- en reststoffen samen met dierlijke mest heeft de laatste tien jaar een flinke ontwikkeling doorgemaakt. In een relatief korte periode werden circa 100 vergistingsinstallaties operationeel. De groei in het aantal vergistingsinstallaties heeft de vraag vergroot naar substraten die naast dierlijke mest vergist kunnen en mogen worden. Deze substraten worden daarom covergistingsmaterialen genoemd. De opname in het rantsoen van een vergistingsinstallatie dient de verhoging van de biogasproductie en een verbetering van het aandeel methaan in biogas. De vergrote vraag naar covergistingsmaterialen heeft geleid tot schaarste aan geschikte materialen wat een prijsverhogend effect heeft.

Op het gebruik van covergistingsmaterialen is de Meststoffenwet van toepassing omdat na vergisting een digestaat resteert dat onder andere uit dierlijke mest bestaat en de bestemming van meststof krijgt. Afval- en reststoffen mogen als covergistingsmaterialen regulier worden toegepast als deze opgenomen zijn in bijlage Aa van de Uitvoeringsregeling Meststoffenwet. Voor opname in deze bijlage wordt aan de hand van een protocol getoetst of een afval- of reststof geschikt is om als covergistingsmaterialen te kunnen worden toegepast. Naast een positieve bijdrage aan de biogasproductie wordt getoetst of zware metalen, arseen en organische microverontreinigingen een milieuhygiënische belemmering vormen. De beoordeling van covergistingsmaterialen volgens dit protocol wordt uitgevoerd door een werkgroep ressorterend onder de Commissie Deskundigen Meststoffenwet (CDM).

De toelatingsprocedure wordt door de praktijk als (te) strikt ervaren. Het aantal toegelaten covergistingsmaterialen wordt te gering gevonden. Een analyse van de knelpunten bij de toelatingsprocedure van afval- en reststoffen als covergistingsmateriaal heeft geresulteerd in het verzoek van het toenmalige ministerie LNV (thans ministerie van Economische Zaken) aan de CDM betreffende een versnelde vorm van toelating van potentiële covergistingstingsmaterialen. Het ministerie heeft gevraagd om een aangepaste beoordelingssystematieken te gebruiken voor de toetsing van residuen van gewasbeschermingsmiddelen en biociden op afval- en reststoffen die bestemd worden om als meststof of als covergistingsmateriaal te worden toegepast. Tevens heeft het ministerie gevraagd om de toetsing te spiegelen aan de Duitse, Belgische en Deense reguleringen voor identieke stoffen en met toepassing van expert judgement in geval gegevens ontbreken. De voorliggende studie geeft een toetsing voor afval- en reststoffen die door LTO-Noord en de Biogas Branche Organisatie zijn aangemeld. De studie werd uitgevoerd in 2011 en is betrokken bij beleidsafweging die geleid heeft tot uitbreiding van bijlage Aa van de Uitvoeringsregeling Meststoffenwet in 2012.

Dit WOt-technisch rapport vervangt WOt-werkdocument 333 doordat een Engelstalig referaat en samenvatting zijn toegevoegd.

Prof dr. Oene Oenema

Voorzitter Commissie Deskundigen Meststoffenwet 



\section{Inhoud}

$\begin{array}{lr}\text { Woord vooraf } & 5\end{array}$

$\begin{array}{lr}\text { Samenvatting } & 9\end{array}$

$\begin{array}{lr}\text { Summary } & 13\end{array}$

$1 \quad$ Inleiding $r$

$\begin{array}{llr}1.1 & \text { Biogasproductie in Nederland } & 15\end{array}$

$\begin{array}{ll}1.2 \text { Microbiologische aspecten } & 15\end{array}$

$\begin{array}{lll}1.3 \text { Meststoffenwet } & 16\end{array}$

$\begin{array}{llr}1.4 & \text { Leeswijzer } & 18\end{array}$

2 Dossiers en methoden van aanpak $r$

2.1 LTO- en BBO-lijst van aangedragen stoffen 19

2.2 Methode van aanpak 19

$\begin{array}{lll}2.3 & \text { Gegevensverzameling } & 20\end{array}$

$3 \quad$ Criteria voor expert judgement $\quad 23$

$\begin{array}{llr}3.1 & \text { Criteria } & 23\end{array}$

3.2 OOM, protocol en alternatieven $\quad 26$

$\begin{array}{lll}3.3 & \text { Betekenis van de alternatieven ten opzichte van het protocol } & 27\end{array}$

$\begin{array}{ll}3.3 .1 & \text { Protocol versie } 2.1 \\ 3.3 .2 & 27\end{array}$

$\begin{array}{lll}3.3 .2 & \text { Alternatief } 1 & 28\end{array}$

$\begin{array}{ll}3.3 .3 \text { Alternatief } 2 & 28\end{array}$

3.3.4 Alternatief $3 \quad 30$

3.3.5 Overwegingen bij de drie gepresenteerde alternatieven $\quad 30$

3.3.6 Afbakening bij expert judgement 31

$4 \quad$ Beoordeling van de stoffen $\quad 33$

$\begin{array}{lll}4.1 & \text { Inleiding } & 33\end{array}$

$\begin{array}{lll}4.2 & \text { Zonnebloemen } & 35\end{array}$

$\begin{array}{lll}4.3 & \text { Bermgras } & 36\end{array}$

$\begin{array}{lll}4.4 & \text { Hooi } & 39\end{array}$

\begin{tabular}{ll}
4.5 & Stro van koolzaad \\
\hline
\end{tabular}

$\begin{array}{lll}4.6 & \text { Tarwe } & 41\end{array}$

$\begin{array}{lll}4.7 & \text { Erwten } & 42\end{array}$

$\begin{array}{lll}4.8 & \text { Maïs } & 43\end{array}$

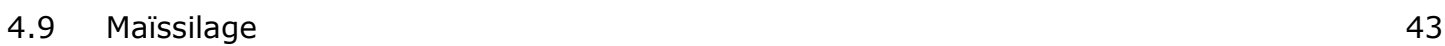

\begin{tabular}{ll}
4.10 & Beheersgras \\
\hline
\end{tabular}

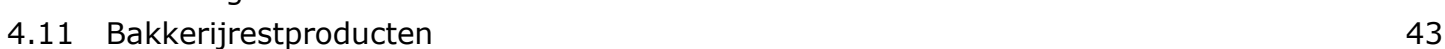

\begin{tabular}{ll}
4.12 & Sojasuiker \\
\hline
\end{tabular}

$\begin{array}{ll}4.13 \text { Uienpulp } & 46\end{array}$

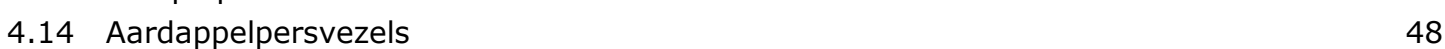

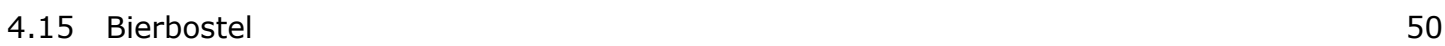

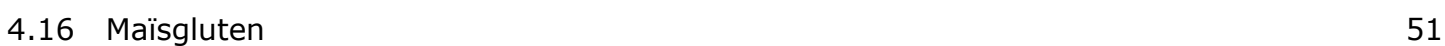

4.17 Melasse (slib) $\quad 52$

4.18 Raapschroot $\quad 54$

4.19 Perspulp van cichoreiwortels $\quad 55$

$\begin{array}{lr}4.20 \text { Wei } & 57\end{array}$ 
$\begin{array}{lll}4.21 & \text { Slib dat vrijkomt bij de productie van salades } & 58\end{array}$

4.22 Bloembollen en afval van sorteren van bloembollen $\quad 59$

4.23 Glycerine van dierlijke herkomst $\quad 62$

$\begin{array}{lll}4.24 & \text { Gersteslijpmeelpellets } & 64\end{array}$

$\begin{array}{ll}4.25 \text { Koffiedik } & 65\end{array}$

$\begin{array}{ll}4.26 & \text { Bietenperspulp } \\ 4.27 & 67\end{array}$

$\begin{array}{ll}4.27 & \text { Aardappelstoomschillen } \\ 4.28 & 68\end{array}$

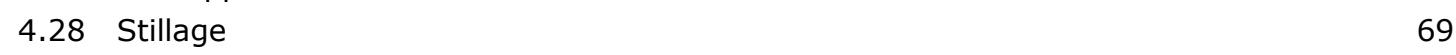

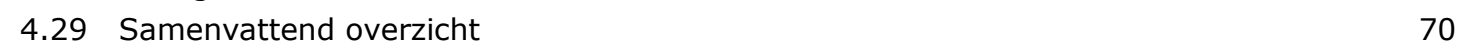

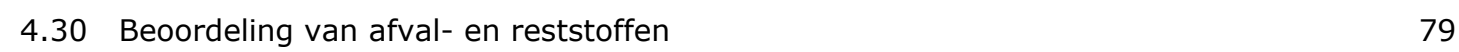

$5 \quad$ Vergelijking met regelgeving in Vlaanderen, Denemarken en Duitsland $\quad 81$

$\begin{array}{lll}5.1 & \text { Vlaanderen } & 81\end{array}$

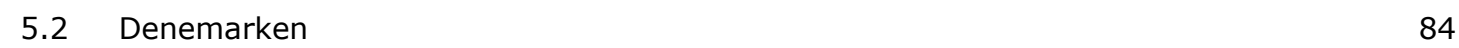

$\begin{array}{lll}5.3 & \text { Duitsland } & 88\end{array}$

5.4 Toetsing aan Vlaamse, Deense en Duitse milieucriteria 90

$6 \quad$ Synthese en conclusies $\quad 93$

$\begin{array}{llr}6.1 & \text { Algemeen } & 93\end{array}$

$\begin{array}{lll}6.2 & \text { Expert judgement } & 93\end{array}$

$\begin{array}{lll}6.3 & \text { Risicobeperking door aansluiting op } \mathrm{GMP}^{+} & 98\end{array}$

6.4 Risicobeperking door aansluiting op Eural-codes 99

$\begin{array}{ll}6.5 & \text { Conclusies en aanbevelingen } \\ \end{array}$

$\begin{array}{lr}\text { Literatuur } & 103\end{array}$

$\begin{array}{lr}\text { Verantwoording } & 105\end{array}$

$\begin{array}{llr}\text { Bijlage } 1 \quad \text { Samenstelling van de werkgroep } & 107\end{array}$

$\begin{array}{lrr}\text { Bijlage } 2 \quad \text { Lijst met afkortingen } & 109\end{array}$

$\begin{array}{llr}\text { Bijlage } 3 \quad \text { Brief LTO-BBO } & 111\end{array}$

$\begin{array}{llr}\text { Bijlage } 4 \quad \text { Gegevensbronnen van de dossiers } & 113\end{array}$

Bijlage 5 Bepaling van de geschatte en de maximaal toelaatbare vracht aan residuen van gewasbeschermingsmiddelen in covergistingsmaterialen en digestaat

$\begin{array}{llr}\text { Bijlage } 6 & \text { Toegelaten actieve stoffen bij teelt van bloembolgewassen } & 147\end{array}$

Bijlage $7 \quad$ Vlaamse lijst van afvalstoffen die in aanmerking komen voor gebruik als secundaire grondstoffen met voorwaarden

Bijlage 8 Lijst van afvalstoffen die in aanmerking komen voor hergebruik in Vlaanderen en Duitsland 


\section{Samenvatting}

De Meststoffenwet verbiedt het gebruik van producten, afvalstoffen en bijproducten als meststoffen in de landbouw, behalve als die producten zijn aangewezen door opname in bijlage Aa van de Uitvoeringsregeling Meststoffenwet. Afval- en reststoffen kunnen dus als grondstof voor de productie van meststoffen worden gebruikt als zij zijn opgenomen. Bij aanwijzing worden deze afval- en reststoffen opgenomen in bijlage Aa van de Uitvoeringsregeling Meststoffenwet. Onderhavig document beschrijft de resultaten van een studie naar mogelijkheden om deze bijlage Aa uit te breiden. De studie is uitgevoerd op verzoek van het ministerie van Economische Zaken naar aanleiding van een verzoek daartoe van het bedrijfsleven.

Het bedrijfsleven (LTO-Noord en de Biogas Branche Organisatie) heeft 21 covergistingsmaterialen aangemeld voor opname in bijlage $A a$, onderdeel IV onder nr. 1 van de Uitvoeringsregeling Meststoffenwet. Het ministerie heeft daar zes stoffen aan toegevoegd. Tevens is gevraagd om een herbeoordeling uit te voeren van eerder aangemelde stoffen voor opname in bijlage Aa in verband met de keuze voor een ander samenstelling van dierlijke mest. Dit betrof 119 stoffen.

De beoordeling van afval- en reststoffen bestemd voor toepassing als covergistingsmateriaal volgt het Protocol Beoordeling Stoffen Meststoffenwet, versie 2.1 (protocol). Informatie over het productieproces en samenstelling met waardegevende bestanddelen en verontreinigende stoffen is voor perspulp van cichoreiwortelen en suikerbieten en voor koffiedik aangeleverd. Voor overige stoffen zijn door middel van bronnenonderzoek gegevens verzameld waarbij veelal datamontage moest worden toegepast. In veel gevallen waren de verzamelde gegevens onvoldoende om het protocol integraal te kunnen toepassen. Om tot beoordeling over te kunnen gaan is expert judgement toegepast in geval de benodigde gegevens onvolledig waren. Criteria voor toepassing van expert judgement zijn opgesteld. Deze criteria zijn afgestemd met de TCB. De beoordelingssystematiek van residuen van gewasbeschermingsmiddelen en biociden is gebaseerd op toepassing van een criterium dat gebaseerd is op het verwaarloosbaar risico (VR).

Toepassing van het protocol leidde frequent tot een negatief oordeel over de plaatsing van afval- en reststoffen op bijlage Aa van de Uitvoeringsregeling Meststoffenwet. Vooral de beoordelingssystematiek van residuen van gewasbeschermingsmiddelen en biociden in Protocol versie 2.1 blijkt een bottleneck. Deze uitkomst knelt met de vraag van de praktijk om meer covergistingsmaterialen te mogen gebruiken. Daarom zijn voor deze studie alternatieve systematieken opgesteld om de residuen van gewasbeschermingsmiddelen en biociden te beoordelen. In onderhavige studie zijn drie alternatieven voorgesteld, die echter nadere beleidsafweging inzake het na te streven beschermingsniveau nodig maken. Deze drie alternatieven houden rekening met afbraak van residuen van gewasbeschermingsmiddelen en biociden.

Er zijn tien werkzame of actieve stoffen (gewasbeschermingsmiddelen en biociden) geselecteerd op basis van de aangeboden stoffen bestemd om als covergistingsmateriaal te worden gebruikt. Hiervan zijn gemiddelde, minimum en maximum vrachten van werkzame stoffen in covergistings-materialen, en overschrijdingsfactoren ten opzichte van de maximaal toelaatbare vracht berekend conform de drie voorgestelde alternatieven. Daarbij zijn gemiddelde vrachten berekend, zowel met als zonder anaërobe afbraak in de vergistingsinstallatie. De minimum- en maximumvrachten zijn gebaseerd op variatie in totaal stikstof en fosfor gehalten, en niet op variatie in gehalten werkzame stoffen. De resultaten van deze vrachtbenaderingen zijn betrokken bij de beoordeling van de $21+6$ stoffen. De stoffen zijn elk afzonderlijk beoordeeld volgens de criteria van het huidige protocol. De milieubezwaarlijkheid van de organische microverontreinigingen is tevens beoordeeld volgens de drie ontwikkelde alternatieven. Het resultaat van de beoordeling is een lijst van stoffen die, afhankelijk van het gekozen beschermingsniveau, in aanmerking kunnen komen voor opname in bijlage Aa van de Uitvoeringsregeling Meststoffenwet. Deze lijst is Tabel 7 (paragraaf 4.29) en wordt samengevat in Tabel S1. Er zijn maar weinig afval- en reststoffen waarbij afdoende feitelijke informatie beschikbaar 
was om tot oordeelvorming over te gaan. Vaker diende op basis van expert judgement oordeelvorming uitgevoerd te worden. Ten slotte bleek voor deze studie bij tien afval- en reststoffen de gegevensverzameling onvoldoende te zijn om tot een verantwoorde risicobeoordeling te komen.

\section{Tabel S1}

Beoordelingsresultaat van de lijst met $21+6$ afval- en reststoffen.

\begin{tabular}{|c|c|c|}
\hline Stof & Oordeel & Toelichtende opmerking \\
\hline $\begin{array}{l}\text { 1. Zonnebloemen (zonnenbloempitten, } \\
\text { geëxtraheerd zonnenbloemmeel }\end{array}$ & negatief & Onvoldoende informatie \\
\hline 2. Bermgras & (negatief) & Individuele partijen positief \\
\hline 3. Hooi & (positief) & Beperkte informatie, expert judgement \\
\hline 4. Stro van koolzaad & (positief) & Beperkte informatie, expert judgement \\
\hline 5. Tarwe & negatief & $\begin{array}{l}\text { Residuen gewasbeschermingsmiddelen, onvoldoende } \\
\text { informatie }\end{array}$ \\
\hline 6. Erwten & (positief) & Beperkte informatie, expert judgement \\
\hline 7. Maïs & Toegelaten & Opgenomen in bijlage Aa van de URMW \\
\hline 8. Maïssilage van hele planten & Toegelaten & Opgenomen in bijlage Aa van de URMW \\
\hline 9. Beheersgras & Toegelaten & Opgenomen in bijlage Aa van de URMW \\
\hline 10. Bakkerij restproducten/koekmix & (positief) & Mits pirimifos-methyl beheerst wordt. \\
\hline 11. Sojasuiker & negatief & Onvoldoende informatie \\
\hline 12. Uienpulp & positief & Geldt voor uienpulp en uienperssap \\
\hline 13. Aardappelpersvezels & (positief) & Beperkte informatie, expert judgement \\
\hline 14. Bierbostel & (positief) & Mits pirimifos-methyl beheerst wordt. \\
\hline 15. Maïsgluten & (negatief) & Te beperkte informatie \\
\hline 16. Melasse (slib) & (positief) & Bietmelasse positief, onvoldoende informatie rietmelasse. \\
\hline 17. Raapschroot & positief & Geen \\
\hline 18. Perspulp van cichoreiwortelen & (positief) & Beperkte informatie, expert judgement. \\
\hline 19. Wei & positief & Geldt voor beoordeelde weiproducten. \\
\hline $\begin{array}{l}\text { 20. Slib dat vrijkomt bij de productie van } \\
\text { salades }\end{array}$ & (positief) & $\begin{array}{l}\text { Geldt voor beoordeelde reststof, onvoldoende informatie } \\
\text { overige slibben. }\end{array}$ \\
\hline $\begin{array}{l}\text { 21. Bloembollen }+ \text { Afval van sorteren van } \\
\text { bloembollen }\end{array}$ & (positief) & $\begin{array}{l}\text { Mits pirimifos-methyl beheerst wordt, gebruik } \\
\text { gewasbeschermingsmiddelen vormt aandachtspunt. }\end{array}$ \\
\hline 22. Glycerine van dierlijke herkomst & negatief & Doorstaat de milieutoets niet. \\
\hline 23. Gersteslijpmeelpellets & (positief) & Mits pirimifos-methyl beheerst wordt. \\
\hline 24. Koffiedik & (positief) & Mits caffeïne beheerst wordt. \\
\hline 25. Bietenperspulp & (positief) & Beperkte informatie, expert judgement. \\
\hline 26. Aardappelstoomschillen & positief & Geen \\
\hline 27. Stillage & (positief) & Mits pirimifos-methyl beheerst wordt. \\
\hline
\end{tabular}

De Nederlandse regels voor toelating voor stoffen die als covergistingsmateriaal zijn vergeleken met die in Vlaanderen, Denemarken en Duitsland. De regelgeving verschilt tussen de landen onderling. Belangrijke verschillen ten opzichte van Nederland zijn de noodzaak om het digestaat op verontreinigende stoffen te onderzoeken, het aandeel van een stof in het rantsoen - dit is de samenstelling van het mengsel mest en covergistingsmaterialen dat vergist wordt - en strikte eisen aan sanitatie van hetzij de grondstoffen voor vergisting, hetzij aan het resulterende digestaat. Zowel Vlaanderen, Denemarken en Duitsland leggen zowel aan de input als aan de output eisen op bij verhandeling voor contaminanten. Lidstaten verschillen in de mate waarin eisen gesteld worden aan sanitatie. Denemarken heeft de meest striktste eisen. 
Het resultaat van de studie is betrokken bij beleidsafweging rond uitbreiding van bijlage Aa van de Uitvoeringsregeling Meststoffen. Deze uitbreiding is inmiddels uitgevoerd.

Als gevolg van de keuze voor wijziging van de samenstelling van de referentie voor dierlijke mest in het protocol hebben dertien stoffen een perspectief voor opname in bijlage Aa indien uitsluitend naar de belasting met zware metalen wordt gekeken. Een aantal van deze stoffen heeft wegens onvoldoende informatie horend bij andere beoordelingscriteria van het protocol echter een negatief oordeel gekregen. Een aantal van deze stoffen is echter toch in bijlage Aa opgenomen omdat van andere afval- en reststromen van vergelijkbare productieprocessen wel afdoende informatie beschikbaar was waardoor een milieutoets op zware metalen en organische microverontreinigingen uitgevoerd kon worden en waarbij de milieutoetsen positief werden doorlopen. Deze negatief beoordeelde stoffen konden meeliften met positief beoordeelde stoffen (bv. aardappelstoomschillen).

De studie heeft betrekking op een select aantal afval- en reststoffen en risico's die daarmee verbonden zijn. Deze studie betreft een beperkt aantal residuen van gewasbeschermingsmiddelen. Het aantal afval- en reststoffen is groter en daarmee ook het aantal aandachtstoffen, bijvoorbeeld door het gebruik van andere gewasbeschermingsmiddelen en/of biociden. De aanbeveling wordt gedaan om deze studie daarom een breder verband te geven. In deze studie is de mate van anaerobe afbraak van een organische microverontreiniging betrokken bij de risicobeoordeling. De anaerobe afbraak is afhankelijk van de temperatuur. De mate van anaerobe afbraak van deze verontreiningen vraagt nog aandacht. Metabolieten van afbraak zijn nog niet betrokken bij deze studie. Vergisting vindt in regel plaats bij verhoogde temperaturen. De invloed van temperatuurverhoging op de mate van afbraak vraagt nadere uitwerking. 



\section{Summary}

The Fertiliser Act prohibits the use of products, wastes and by-products as agricultural fertilisers, unless these substances are listed in Annex Aa to the Fertiliser Act. According to stakeholders LTONoord and Biogas Branche Organisatie (BBO), the limited number of listed wastes and by-products restricts the viability of anaerobic digesters for biogas production that co-digest manure. This document describes the results of a study into the possibilities for expanding this list. The study was conducted for the Ministry of Economic Affairs following a request by the stakeholders.

LTO Noord and BBO submitted 21 wastes and by-products for inclusion in Annex Aa (Section IV) as co-digestion materials. The Ministry added another 6 wastes and by-products and also asked for a reevaluation of 119 substances previously rejected for inclusion in Annex $\mathrm{Aa}$, in connection with a change to the reference composition for animal manure. A risk assessment was carried out on the suitability of these substances for biogas production and on possible adverse effects on the environment. This assessment was carried out in accordance with the protocol for assessing the value and risks of waste used as a fertiliser, version 2.1 .

Production information and data on composition and nutrient and contaminant contents were provided by stakeholders for sugar beet pulp, chicory root pulp and coffee grounds. Similar data for other substances were collected from a study of data sources, often supplemented by combining data from different sources. In most cases, the information collected was insufficient to fully comply with the data requirements of the protocol. In these cases expert judgment was applied. Criteria for expert judgment were formulated and agreed with the Technical Committee on Soil Protection (Technische Commissie Bodem, TCB).

Application of the protocol frequently led to a negative risk assessment and the subsequent rejection of the wastes and by-products concerned for inclusion in Annex Aa to the Fertiliser Act. The risks associated with residues of pesticides and biocides were a particular problem in this regard because the evaluation of these risks was based on a negligible risk criterion (VR). To resolve this problem, two alternative evaluation methods for residues of pesticides and biocides were developed. All three methods take into account the degradation of pesticide and biocide residues in the soil, but use different risk criteria and permitted soil input levels for residues. The decision on which alternative should be used in the risk assessment is a policy decision to be made by the ministry.

Ten active components of pesticides and biocides were selected on the basis of the wastes and byproducts proposed by stakeholders and the ministry. Average, minimum and maximum loads of these active substances in the co-digestion materials were calculated from collected data, and excess factors with respect to the maximum permissible load were calculated according to the three methods.

Average loads were also calculated, both with and without anaerobic decomposition in the digester. The minimum and maximum loads were based on variation in the levels of total nitrogen and phosphorus in the wastes and by-products, not on variation in the levels of active substances. Each of these 21+6 wastes and by-products was assessed according to the criteria in the current protocol, version 2.1, and then according to the load approach of the three methods for pesticide and biocide residues. The outcome of the review is a list of substances which, depending on the chosen level of protection, may be eligible for inclusion in Annex Aa to the Fertiliser Act (Section 4, paragraph 29). The results are summarised in Table S1. Sufficient factual information to proceed to a formal judgement according to the protocol was available for only a few of the wastes and by-products and many of the assessments relied on expert judgment. For ten wastes and by-products limited or insufficient data was available for the risk assessment.

The Dutch regulations concerning co-digestion materials were compared with those in Flanders, Denmark and Germany. In the Netherlands, the risk assessment is based primarily on the input materials, whereas in Flanders, Denmark and Germany it is based on the input and output materials. The major differences with the Dutch regulations are the obligation to analyse the digestate for the presence of contaminants, the proportion of a substrate (co-digestion material) in the digester feedstock, and strict requirements for sanitation of either the raw materials for digestion (substrates) 
or the resulting digestate. Flanders, Denmark and Germany impose standards for permitted levels of contaminants on both the input and the output materials to be used as fertiliser. Sanitation requirements also differ. Denmark has the strictest requirements.

\section{Table S1}

Results of the risk assessment for the $21+6$ wastes and by-products

\begin{tabular}{|c|c|c|}
\hline Waste or by-product & Result & Explanatory note \\
\hline $\begin{array}{l}\text { 1. Sunflowers } \\
\text { (sunflower seeds, extracted sunflower meal }\end{array}$ & negative & Insufficient information \\
\hline 2. Roadside grass & (negative) & Some batches positive \\
\hline 3. Hay & (positive) & Limited information, expert judgment \\
\hline 4. Oilseed rape straw & (positive) & Limited information, expert judgment \\
\hline 5. Wheat & negative & $\begin{array}{l}\text { Residues of plant protection products, } \\
\text { insufficient information }\end{array}$ \\
\hline 6. Peas & (positive) & Limited information, expert judgment \\
\hline 7. Maize & Approved & Already included in Annex Aa \\
\hline 8. Maize silage from whole plants & Approved & Already included in Annex Aa \\
\hline 9. Grass from grassland under conservation management & Approved & Already included in Annex Aa \\
\hline 10. Bakery wastes including dough & (positive) & Provided pirimiphos-methyl is controlled. \\
\hline 11. Soy sugar & negative & Insufficient information \\
\hline 12. Onion pulp & positive & $\begin{array}{l}\text { Applies to onion pulp remaining after } \\
\text { distillation of onion oil and the thin } \\
\text { fraction from separation of the pulp. }\end{array}$ \\
\hline 13. Potato pulp & (positive) & Limited information, expert judgment \\
\hline 14. Brewers' grains & (positive) & Provided pirimiphos-methyl is controlled. \\
\hline 15. Maize gluten & (negative) & Information too limited \\
\hline 16. Molasses (sludge) & (positive) & $\begin{array}{l}\text { Beet molasses positive, insufficient } \\
\text { information sugar cane molasses }\end{array}$ \\
\hline 17. Rape cake (pressed rape seed) & positive & None \\
\hline 18. Pressed chicory root pulp & (positive) & Limited information, expert judgment. \\
\hline 19. Whey & positive & Applies to designated whey products \\
\hline $\begin{array}{l}\text { 20. Sludge from treatment of wastewater from salad } \\
\text { production }\end{array}$ & (positive) & $\begin{array}{l}\text { Applies to assessed residues, insufficient } \\
\text { information on other sludges. }\end{array}$ \\
\hline 21. Bulbs + Waste from sorting bulbs & (positive) & $\begin{array}{l}\text { Provided pirimiphos-methyl controlled, } \\
\text { use of pesticides is a concern }\end{array}$ \\
\hline 22. Glycerine of animal origin & negative & Too high concentrations of metals \\
\hline 23. Barley grindings (wastes), pelletised & (positive) & Provided pirimiphos-methyl is controlled \\
\hline 24. Coffee grounds & (positive) & Provided caffeine is controlled \\
\hline 25. Pressed sugar beet pulp & (positive) & Limited information, expert judgment \\
\hline 26. Potato peelings, released by steaming & positive & None \\
\hline 27. Stillage & (positive) & Provided pirimiphos-methyl is controlled \\
\hline
\end{tabular}

Due to the choice of a different reference composition for manure in the protocol, 13 wastes and byproducts of the 119 re-reviewed materials may now be included in Annex Aa, based solely on data on contamination with heavy metals. However, other criteria prevented the inclusion of all these 13 wastes. Using information on other wastes and by-products from similar production processes, but from different stakeholders, opened up the prospect of inclusion. The ministry has already increased the number of wastes and by-products listed in Annex Aa to the Fertiliser Act, based on the results of this study.

The study covers a select number of wastes and by-products and the risks associated with them, as well as a limited number of pesticide residues. As the number of potential wastes and by-products for inclusion in Annex Aa is much larger, the number of active substances from plant protection products and biocides is also larger. The risk assessment used in this study took into account the degree of anaerobic degradation of organic contaminants, but metabolites were not considered. The influence of temperature on the degree of degradation requires further elaboration. It is therefore recommended that a wider study of more active substances and their metabolites should be carried out. 


\section{$1 \quad$ Inleiding}

\subsection{Biogasproductie in Nederland}

Winning van biogas afkomstig van vergisting van organische stof is een proces dat sinds al jaar en dag wordt toegepast in Nederland. Eind jaren zeventig waren vrijwel alle RWZI's uitgerust met een vergistingsinstallatie. Op landbouwbedrijven zijn in de jaren 1970-1990 op boerderijschaal vergisters in gebruik geweest maar naast technische problemen, zijn de toenmalige economische crisis, dalende energieprijzen en dalende interesse voor het milieu oorzaken voor het verdwijnen van een perspectief voor vergisting op landbouwbedrijven (Verbong et al., 2001). De beeldvorming over de duurzaamheid van energieproductie en het perspectief van het gebruik van hernieuwbare energiebronnen heeft het denken over de toepassing van energie afkomstig van vergisting van biomassa gewijzigd. Samen met verbeterde technologieën heeft dat geleid tot een nieuwe impuls voor het ontwikkelen van vergistingsinstallaties op landbouwbedrijven. Rond 2005 begint in Nederland deze ontwikkeling vorm te krijgen mede gestuurd door subsidies op de productie van groene stroom.

Biogasproductie uit biomassa heeft in het laatste decennium een andere maatschappelijke perceptie gekregen doordat deze vorm van energiewinning opgevat wordt als een vorm die positief bijdraagt aan de reductie van het gebruik van fossiele brandstof en broeikasgassen (reduction of energy-, carbon- \& greenhousegasses footprints). Het aantal landbouwbedrijven met een vergistingsinstallatie groeide gestaag van 5 in 2005 tot ca. 100 in 2009 (De Hoop et al., 2010). In de jaren 1970-1990 waren de vergistingsinstallaties klein van omvang (50-100 Kwh) en werd in hoofdzaak dierlijke mest vergist (monovergisting). De nieuwe generatie vergisters zijn groter (250-500 Kwh). Veelal is sprake van vergisting van dierlijke mest met andere vormen van biomassa van plantaardige of dierlijke herkomst. Deze vorm van vergisting wordt covergisting genoemd.

Het doel van covergisting is in beginsel om de opbrengst en kwaliteit van het biogas (hoger aandeel methaan, beheersing van $\mathrm{H}_{2} \mathrm{~S}$ vorming) te verhogen en te verbeteren. De laatste jaren tekenen zich ook ontwikkelingen af waarbij geen dierlijke mest wordt gebruikt, maar andere vormen van biomassa's. Een voorbeeld daarvan is monovergisting van snijmaïs. Naast vergisters op boerderijschaal wordt op grotere - regionale - schaal vergisting van GFT-afval toegepast. In alle gevallen betreft het in Nederland natte vormen van vergisting. Dit zijn systemen waarbij een vloeibare fase vergist wordt. Met droge vormen van vergisting van bijvoorbeeld bermmaaisel wordt in Nederland nu geëxperimenteerd. Bij een droge vorm van vergisting wordt stapelbare biomassa vergist. In omliggende landen kent deze droge vorm van vergisting al praktische uitvoering.

\subsection{Microbiologische aspecten}

Vergisting is een microbiologisch proces dat al vele eeuwen door mensen wordt toegepast. Voorbeelden daarvan zijn de productie van wijn, bioethanol, zuurkool, silage. Elk vergistingsproces vraagt sturing om die opbrengst en kwaliteit te krijgen die nodig is voor een verantwoorde en renderende bedrijfsvoering. Bij de toepassingen van vergistingsprocessen voor de productie van voedings- en genotsmiddelen en bioethanol worden bij de selectie van grondstoffen strikte kaders toegepast. Afval- en reststoffen worden niet toegepast. Biogasproductie uit anaërobe (zuurstofloze) afbraak van organische stoffen van biomassa (substraat) door methaanvormende bacteriën is een bijzondere vorm van vergisting die net als bij de productie van wijn of bioethanol goede beheersing vraagt van het vergistingsproces (zie kader). Bij vergisting ten behoeve van biogasproductie worden vaak afval- en reststoffen aangemerkt als geschikte substraten voor biogasproductie. 
Veel afval- en reststoffen kunnen nuttig hergebruikt worden als covergistingsmateriaal. Vergisting is geen restloos proces. Niet alle organische stof van een substraat wordt volledig omgezet tot biogas en niet alle stof van een substraat is organisch van aard. Vergisting resulteert in biogas en een digestaat (vast of vloeibaar). De samenstelling en eigenschappen van een digestaat zijn afhankelijk van de substraten en de condities van het vergistingsproces. Door de eisen die methaanvormende bacteriën stellen aan de voeding en het milieu heeft het resulterende digestaat eigenschappen en een samenstelling die vergelijkbaar zijn met die van dierlijke mest. Door omzetting van organische stof heeft digestaat een betere landbouwkundige kwaliteit dan dierlijke mest. Het digestaat heeft o.a. een hoger aandeel minerale ammoniumstikstof en is homogener van samenstelling. Het gebruik van afvalen reststoffen leidt ook tot de aanvoer van nevenbestanddelen die een risico kunnen vormen voor mens, dier, gewas en milieu. Om deze risico's uit te sluiten stelt de Rijksoverheid regels aan het gebruik van afval- en reststoffen die bestemd worden als substraat voor vergisting. Deze regels zijn uitgewerkt in de Meststoffenwet en de Wet Milieubeheer. Indien aan voorwaarden wordt voldaan kan het digestaat als meststof worden gebruikt. De Meststoffenwet reguleert deze gebruiksvorm. Indien niet aan deze voorwaarden wordt voldaan, dan is het digestaat van de vergisting van afval- en reststoffen een afvalstof waarop bepalingen van de Wet Milieubeheer gelden.

\section{Kader: Vergistingsproces}

Biogas is een mengsel van methaan en koolzuur dat uitsluitend onder strikt zuurstofloze omstandigheden (anaërobie) door bacteriën door omzetting van organische stof gevormd wordt. Het microbiologische proces kent vier fasen.

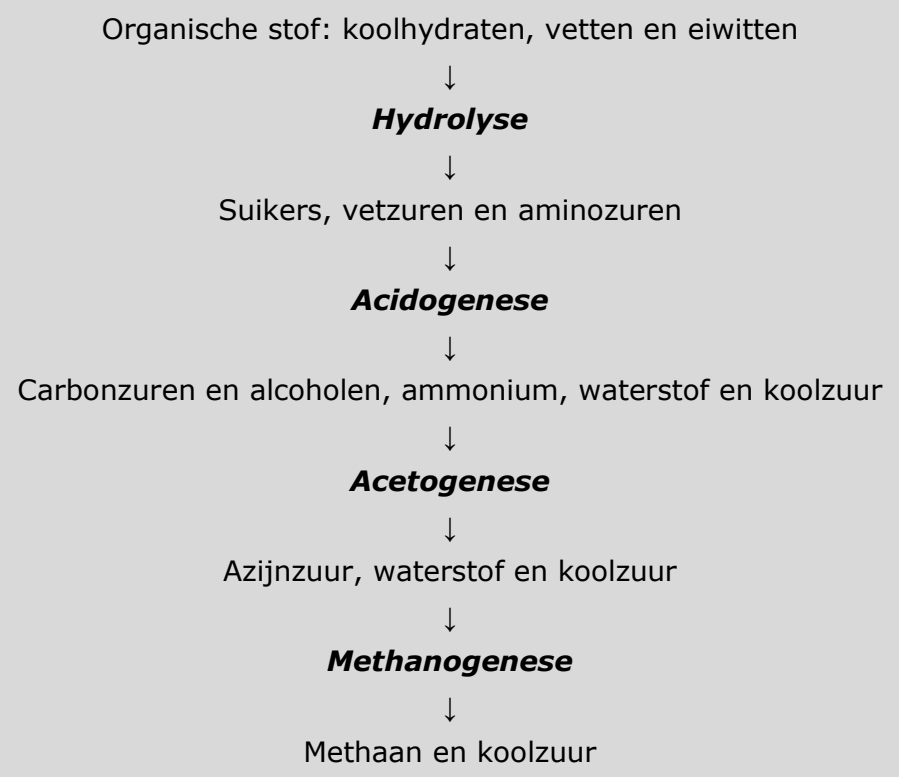

Bij elke fase zijn andere soorten bacteriën betrokken. Het biologische proces eist een goede beheersing via de voeding van de bacteriën met de juiste organische stoffen (substraat), de juiste mineralen in de juiste verhouding en de juiste essentiële vitaminen. Daarnaast bepalen temperatuur, zuurgraad en procescondities (fysische vorm van het substraat en rantsoenering) de mate en kwaliteit van de biogasproductie. Er zijn psychrofiele $\left(<10^{\circ} \mathrm{C}\right)$, mesofiele $\left(35-40^{\circ} \mathrm{C}\right)$ en thermofiele $\left(55^{\circ} \mathrm{C}\right)$ vergistingsprocessen waarbij telkens verschillende soorten bacteriën betrokken zijn. Uit suikers en sterk verhoute biomassa met veel lignines zijn geen geschikte covergistings-materialen. Suikers leiden tot een snelle verzuring. Om die verzuring te voorkomen dient het aandeel in het rantsoen strikt gecontroleerd worden. Lignines kunnen alleen onder de aanwezigheid van zuurstof worden afgebroken.

\subsection{Meststoffenwet}

Aan het gebruik van afval- en reststoffen als covergistingsmateriaal stelt de Meststoffenwet een verbod indien het digestaat als meststof wordt toegepast. Het gebruik van een afval- of reststof als covergistingsmateriaal is alleen mogelijk als de stof is opgenomen in een lijst van bijlage Aa van de 
Uitvoeringsregeling Meststoffenwet (URMW). Over de opname beslist de Staatssecretaris van het ministerie van $\mathrm{EZ}^{1}$. Bij deze beslissing wordt het oordeel betrokken dat opgesteld is door de Commissie van Deskundigen Meststoffenwet (CDM). Bij het opstellen van het oordeel volgt de CDM het Protocol Beoordeling Stoffen Meststoffenwet, versie 2.1 (Van Dijk et al., 2009; WOtwerkdocument nr. 167; http://www.cdm.wur.nl/NL/Producten/toetsing+stoffen/). Als een afval- of reststof eenmaal opgenomen is in bijlage Aa van de URMW is vrije verhandeling mogelijk. Een afvalof reststof staat niet op naam van een producent of handelshuis.

De toelatingsprocedure wordt door de praktijk als te strikt ervaren (De Hoop et al., 2010). Het aantal toegelaten covergistingsmaterialen wordt te gering gevonden, waardoor de prijzen voor covergistingsmaterialen hoog worden gevonden.

Bij de uitvoering van de toetsing van bepaalde reststoffen aan voornoemd Protocol Beoordeling Stoffen Meststoffenwet (Protocol) werden door het toenmalige ministerie van LNV (ing. H. Bos) en de CDM-werkgroep knelpunten gesignaleerd:

1. Het Protocol hanteert een systematiek die leidt tot een strengere beoordeling van residuen van gewasbeschermingsmiddelen en biociden dan bij andere beoordelingskaders - bv. bij toelating van gewasbeschermingsmiddelen en biociden - wordt gehanteerd. Als gevolg daarvan leidt toetsing aan voornoemd Protocol relatief vaak tot een negatief oordeel.

2. Het Protocol toetst aan Verwaarloosbaar Risico $\left(V_{\text {bodem }}\right)$. Vaak ontbreken bodemnormen voor $V_{R_{\text {bodem }}}$ of Maximaal Toelaatbaar Risiconiveau ${ }^{2}\left(M_{T} R_{\text {bodem }}\right)$. Het ontbreken van een normwaarde leidt, conform het Protocol, tot een negatief oordeel.

3. In geval een detectielimiet wordt opgegeven voor een contaminant, wordt de milieutoets van het Protocol uitgevoerd met de waarde van die limiet. Detectielimieten zijn vaak dusdanig hoog ${ }^{3}$ dat dit leidt tot een negatief oordeel. Daarnaast introduceert het rekenen met een fictieve waarde onzekerheid bij de uitkomst van de milieutoets. De grondslag voor het oordeel is onzeker en daardoor de basis voor een negatief oordeel.

Deze knelpunten zijn tijdens een overleg met het toenmalige ministerie LNV (thans EZ) op 22 juni 2010 besproken. Het overleg heeft geresulteerd in drie verzoeken van het ministerie LNV (thans EZ) aan de Commissie van Deskundigen Meststoffenwet (CDM) betreffende:

1. Een inventarisatie over normenstelsels met hun beschermingsdoel en onderliggende systematiek;

2. De toepassing van verschillende systematieken op afval- en reststoffen die bestemd worden om als meststof of als covergistingsmateriaal te worden toegepast met spiegeling aan Duitse, Belgische en Deense regulering voor identieke stoffen; en

3. Opties voor herziening van normen voor anorganische en organische contaminanten.

Deze drie verzoeken met onderliggende vragen werden uitgewerkt in een projectvoorstel. Tijdens een startbijeenkomst met vertegenwoordigers van het toenmalige ministerie LNV, het toenmalige ministerie VROM (thans I\&M), RIVM, NMI en Alterra op 8 september 2010 werden onderwerpen van verzoeken geprioriteerd. Prioriteit werd gelegd bij de beoordeling van 21 stoffen, ingediend door LTONoord en de Biogas Branche Organisatie. De lijst met stoffen is door het ministerie EZ uitgebreid met 6 andere stoffen.

De gesignaleerde knelpunten vragen om een andere beoordelingssystematiek voor residuen van gewasbeschermingsmiddelen en biociden. De uitwerking van een andere systematiek vraagt aandacht. Residuen van gewasbeschermingsmiddelen en biociden worden getoetst op basis van verwaarloosbaar risico. Deze vorm van toetsing beschermt de bodemkwaliteit, maar kan mogelijk versoepeld worden.

\footnotetext{
${ }^{1}$ Dit WOt-document gaat uit van de in juni 2013 geldende situatie. De studie is geëntamineerd door het ministerie van LNV later opgegaan in het ministerie van EL\&I (en EZ). Deze - inmiddels historische - ontwikkelingen worden hier niet meer in beeld gebracht.

${ }^{2} \mathrm{MTR}_{\text {bodem }}=100 * \mathrm{VR}_{\text {bodem }}$

${ }^{3}$ Analysegegevens zijn vaak afkomstig van onderzoek in het kader van voedselveiligheid voor mens of dier. De beschermingscriteria hiervoor verschillen van die voor de beoordeling van contaminanten in co-vergistingsmaterialen, waardoor volstaan kan worden met hogere detectielimieten voor onderzoek naar voedselveiligheid.
} 
Het ministerie $\mathrm{EZ}^{4}$ heeft verzocht om de mogelijkheden te verkennen van een soepeler vorm van de beoordeling van residuen van gewasbeschermingsmiddelen en biociden. Dit raakt de bescherming van de bodem. Daarom heeft het ministerie I\&M de Technische Commissie Bodem (TCB) gevraagd advies uit te brengen over de betekenis van een versoepeling van normenstelsels voor de bodem bij toelating van covergistingsmaterialen ${ }^{5}$. Daarbij werd verzocht om de adviezen over beide adviezen over covergistingsmaterialen van de TCB en de CDM af te stemmen opdat beide commissies kunnen aansluiten op elkaars advies. Omdat normen voor de bescherming van de bodem niet voor alle actieve stoffen van gewasbeschermingsmiddelen en biociden bekend zijn, zal daarbij een vorm van expert judgement nodig zijn. Er heeft afstemming plaatsgevonden tussen CDM en TCB over de criteria voor expert judgement. Deze criteria worden behandeld in hoofdstuk 3 van dit technisch rapport. De TCB heeft het advies over covergistingsmaterialen uitgebracht (TCB, 2010). Dit advies is betrokken bij de uitvoering van de risicobeoordeling.

Dit WOt-technical report is gericht op de risicoanalyse van afval- en reststoffen die bestemd worden voor covergstingsmateriaal. Alternatieven voor de beoordeling van de residuen van gewasbeschermingsmiddelen en biociden (overige organische microverontreinigingen of OOM) worden gegeven. Een overzicht van regelgeving voor covergistingsmaterialen in België, Denemarken en Duitsland wordt daarbij betrokken. Het rapport is opgesteld door een door de Commissie van Deskundigen Meststoffenwet daartoe ingestelde ad-hoc werkgroep van deskundigen van het RIVM, NMI en Wageningen Environmental Research (Alterra). De samenstelling van de werkgroep wordt gegeven in Bijlage 1. Bijlage 2 bevat de lijst met afkortingen.

\subsection{Leeswijzer}

Dit rapport is als volgt opgebouwd. In hoofdstuk 2 worden de overzichten van de aangemelde afvalen reststoffen gegeven waaraan de bestemming van covergistingsmateriaal wordt gegeven. Een overzicht wordt gegeven over de wijze waarop data voor de uitvoering van de risicoanalyse verzameld zijn. De aanpak en de methoden worden beschreven. In hoofdstuk 3 worden de criteria voor expert judgement gegeven. Hoofdstuk 4 geeft de resultaten van beoordeling van de covergistingsmaterialen. In hoofdstuk 5 worden de regels voor covergistingsmaterialen in België, Denemarken en Duitsland gegeven. Hoofdstuk 6 geeft de synthese, evalueert en doet aanbevelingen.

\footnotetext{
${ }^{4}$ Het onderzoek is uitgevoerd na opdracht van het toenmalig ministerie LNV aan de CDM. Het ministerie is daarop volgend samengegaan met het ministerie EZ tot het ministerie EL\&I. Een aanvullende opdracht is gegeven door het ministerie EL\&I (thans EZ). De goedkeuring aan dit werkdocument werd uitgebracht door het minsterie van EZ. In dit werkdocument wordt daarom het ministerie van EZ als opdrachtgever aangemerkt.

${ }^{5}$ Adviesaanvraag Technische Commissie Bodem inzake covergisting, brief met kenmerk DP2010021155 van 2 augustus 2011.
} 


\section{Dossiers en methoden van aanpak}

\subsection{LTO- en BBO-lijst van aangedragen stoffen}

LTO en BBO hebben 21 stoffen aangedragen voor opname in bijlage Aa van de URMW, het verzoek daartoe wordt gegeven in Bijlage 3. Dit betreft:

1. Zonnebloemen

2. Bermgras

3. Hooi

4. Stro van koolzaad

5. Tarwe

6. Erwten

7. Maïs

8. Maïssilage van hele planten (dit vooral voor biologische bedrijven)

9. Beheersgras

10. Bakkerijrestproducten/koekmix

11. Sojasuiker

12. Uienpulp

13. Aardappelpersvezels (aardappelvezels)

14. Bierbostel

15. Maïsgluten

16. Melasse (slib)

17. Raapschroot

18. Perspulp van cichoreiwortelen (Cigarant)

19. Wei

20. Slib dat vrijkomt bij de productie van salades (bevat aardappelen en vet, producent is FanoFineFoods)

21. Bloembollen + Afval van sorteren van bloembollen

Daarnaast heeft het ministerie EZ (bij het uitvoeren van het verzoek nog LNV) verzocht om bij de beoordeling de volgende zes afval- en restproducten te betrekken:

22. Glycerine van dierlijke herkomst

23. Gersteslijpmeelpellets

24. Koffiedik

25. Bietenperspulp

26. Aardappelstoomschillen

27. Stillage

Nadien heeft het ministerie EZ verzocht om expert judgement ook toe te passen op afval- en reststoffen waarvoor een verzoek was ingediend voor opname in bijlage Aa van de URMW en die al beoordeeld waren. Dit betreft in hoofdzaak dossiers die tot 2008 ingediend werden bij het ministerie LNV-Directie Kennis en Innovatie. Ook enkele verzoeken die na 2008 werden ingediend bij het ministerie LNV Dienst Regelingen (nu RVO.NL) en beoordeeld werden door de CDM-werkgroep Toetsing Stoffen zijn herbeoordeeld. De herbeoordeling betreft covergistingsmaterialen die om diverse redenen niet geschikt werden bevonden voor opname op de positieve lijst.

\subsection{Methode van aanpak}

De beoordeling van de dossiers van de stoffen is uitgevoerd door de ad-hoc werkgroep van de CDM samengesteld uit deskundigen van RIVM, Wageningen Environmental Research (Alterra) en NMI (Bijlage 1). 
Stoffen zijn beoordeeld op geschiktheid als covergistingsmateriaal op basis van het Protocol Beoordeling Stoffen Meststoffenwet, versie 2.1. In geval bepaalde informatie over de stoffen ontbreekt, dan is op basis van expert judgement de beoordeling uitgevoerd. Daarvoor zijn door de werkgroep criteria geformuleerd voor het uitvoeren van een risico-analyse in geval gegevens over contaminanten ontbreken. De criteria die gelden bij expert judgement zijn afgestemd met de TCB en worden gegeven in hoofdstuk 3. Bij de beoordeling van residuen van gewasbeschermingsmiddelen en biociden zijn door het RIVM alternatieve beoordelingssystematieken opgesteld. Hoofdstuk 3 gaat in op deze op expert judgement gebaseerde alternatieven voor risico-analyses.

Regelgeving voor toelating van covergistingsmaterialen in Vlaanderen (België), Denemarken en Duitsland is ontsloten. De grondslagen van de regelgevingen verschillen onderling en verschillen ook met de Nederlandse regelgeving. Deze grondslagen zijn voor België en Duitsland beschreven door De Hoop et al. (2010). Dit technisch rapport gebruikt deze beschrijving als basis, een uitwerking ervan wordt in onderhavig document gegeven. Voor Denemarken wordt de grondslag beschreven. Vervolgens is nagegaan welke stoffen van de lijst van LTO-BBO-ministerie EZ in deze landen zijn toegelaten en onder welke voorwaarden.

\subsection{Gegevensverzameling}

De beoordeling is gebaseerd op bureaustudies. Chemisch analytisch onderzoek op de aanwezigheid van contaminanten in monsters van de te toetsen stoffen is niet uitgevoerd.

De gegevens die nodig zijn om een afval- of reststof te beoordelen op geschiktheid als covergistingsmateriaal worden gegeven in bijlage 7 van het Protocol Beoordeling Stoffen Meststoffenwet (versie 2.1). Het ministerie EZ heeft LTO, BBO en andere belanghebbenden verzocht om deze gegevens beschikbaar te stellen. Dit verzoek heeft geleid tot de aanlevering van dossiers voor koffiedik, bietenperspulp, cigarant en een voedingsmiddelenslib. Leden van de ad-hoc werkgroep hebben daarop contact gezocht met handelshuizen en producenten om aanvullende informatie te verkrijgen over de productieprocessen waarbij de aangeboden afval- en reststoffen vrijkomen en in het bijzonder om gegevens te verkrijgen over de waardegevende bestanddelen in samenhang met anorganische en organische contaminanten (inclusief residuen van gewasbeschermingsmiddelen en biociden). De respons hierop was te gering (vier gehalten aan zware metalen en arseen in hooi). De ervaring is dat betrokkenen bij de lijst van LTO-BBO niet bekend zijn met gehalten aan contaminanten in de afval- en reststoffen. Waardegevende bestanddelen (nutriënten en voederkwaliteit) zijn (deels) nog wel bekend. De ervaring van de ad hoc-CDM-werkgroep is ook dat er uit concurrentie-overwegingen onwil bestaat om deze gehalten nog te gaan bepalen in de aangeboden afval- of reststoffen. De concurrent draagt namelijk niet bij aan de kosten van de vorming van het dossier met daaraan verbonden analysekosten.

Daardoor verliep de gegevensverzameling stroef. Het project werd daarop verlengd door uitbreiding met aanvullend bronnenonderzoek. Gegevens voor beoordeling werden tenslotte verkregen uit dossiers van vergelijkbare afval- en reststromen waarvoor in het verleden een verzoek voor opname in bijlage Aa van de URMW bij het ministerie LVN-DKI of LNV-DR was ingediend. Daarnaast werden openbare gegevensbronnen van de catalogus van de bibliotheek van WUR geraadpleegd. Dit betreft wetenschappelijke publicaties. Bovendien werden internetbronnen geraadpleegd. Ten slotte werden gegevens ontsloten uit databestanden van wetenschappelijke instellingen. De bronnen die geraadpleegd zijn, worden per dossier gegeven in Bijlage 4.

Bij vrijwel alle dossiers diende een vorm van datamontage uitgevoerd te worden. Gehalten aan zware metalen en arseen zijn bij het bronnenonderzoek nog wel getraceerd, meetgegevens over de organische microverontreinigingen van de $\mathrm{MW}$ en over residuen van gewasbeschermingsmiddelen en biociden zijn beduidend schaarser te traceren. Een beperkt aantal afval- en reststoffen is voorzien van een volledige analyse op waardegevende bestanddelen en de anorganische en organische contaminanten die door de Meststoffenwet zijn aangewezen. 
De wijze van rapportage van meetgegevens verschilt. Alle gegevensbronnen melden gehalten. Een deel meldt een gemiddelde waarde. Nog een kleiner deel meldt de waarde van de mediaan. Informatie over standaardfout met aantal waarnemingen is daardoor niet toereikend. Daardoor kon geen weging uitgevoerd worden van de gerapporteerde waarden op basis van het aantal waarnemingen. De resultaten van de milieutoetsen berusten derhalve op gemiddelde waarden. De resultaten van deze vorm van milieutoets worden bij iedere te beoordelen stof (covergistingsmateriaal) gegeven. Een worst-case-situatie is gesimuleerd door gerapporteerde minimumwaarden voor waardegevende bestanddelen (stikstof en fosfaat) te koppelen aan gerapporteerde maximumwaarden voor drogestof, zware metalen en arseen. Niet bij alle te beoordelen stoffen werden afdoende waarnemingen gevonden om een dergelijke worst-case-simulatie uit te voeren. Het resultaat van deze worst-caseberekeningen wordt gegeven bij het samenvattend overzicht van alle berekeningen.

Informatie over residuen van gewasbeschermingsmiddelen en biociden bleek zeer schaars beschikbaar. Daarop zijn door het RIVM ramingen uitgevoerd van de gehalten die verwacht kunnen worden, gelet op het toegelaten gebruik van gewasbeschermingsmiddelen en biociden. Daarnaast is bij dit onderdeel van de toetsing bij enig ontbrekend gegeven gebruik gemaakt van waarden voor maximum residu limieten (MRL). Het RIVM heeft alternatieven opgesteld voor de bepaling van de jaarvracht van een residu van een gewasbeschermingsmiddel of biocide. In hoofdstuk 4 wordt hierop ingegaan. De methode van aanpak wordt gegeven in de rapportage van het RIVM. Deze rapportage is opgenomen in Bijlage 5. 



\section{Criteria voor expert judgement}

\section{$3.1 \quad$ Criteria}

Het Protocol Beoordeling Stoffen Meststoffenwet, versie 2.1. $\left(\right.$ protocol $^{6}$ ) geeft de criteria voor de beoordeling van stoffen op geschiktheid als covergistingsmaterialen:

1. De identiteit van de stof is bekend en eenduidig te karakteriseren.

2. De stof draagt positief bij aan de biogasproductie.

3. Het residu van de stof mag geen ongewenste bijwerking hebben (bv. vetten die de bodem hydrofoob maken).

4. Het digestaat (covergiste mest) dat resulteert na vergisting heeft een landbouwkundige waarde.

5. Bij verantwoord landbouwkundig gebruik leidt het digestaat niet tot onaanvaardbare hoge vrachten aan anorganische en organische contaminanten.

Toepassing van het protocol leidt tot een negatief oordeel indien gegevens niet volledig zijn. Omdat niet alle gegevens voor het opstellen van het oordeel beschikbaar zijn, heeft het ministerie EZ verzocht om de beoordeling van de $21+6$ stoffen ook op basis van expert judgement uit te voeren in geval niet volledig volgens het protocol kan worden getoetst. De criteria voor de beoordeling op basis van expert judgement zijn daarop vastgesteld. Deze criteria zijn op verzoek van het ministerie EZ met de TCB afgestemd.

Expert judgement hanteert eveneens deze criteria maar hanteert een meer generieke benadering dan voorgeschreven door het protocol. De stappen van de beoordeling worden gegeven in schema 1 (criteria 1 tot en met 4) en schema 2 (criterium 5). Het risico van contaminatie weegt bij expert judgement zwaarder dan de geschiktheid van een afval- of reststof om gebruikt te worden als covergistingsmateriaal.

Stap 1 (schema 1). De stof moet karakteriseerbaar zijn. Indien een stof niet te karakteriseren is op basis van algemene informatie over herkomst, productieproces, samenstelling en daaraan verbonden inschatting van risico's van contaminatie, kan geen verantwoord advies op basis van expert judgement opgesteld worden.

Stap 2 (schema 1). De samenstelling van de stof moet zich lenen voor toepassing als covergistingsmateriaal. Op basis van expert judgement wordt bepaald of in hoofdzaak organische stoffen aanwezig zijn die uitsluitend aeroob kunnen worden afgebroken (bv. lignine) dan wel ook anaëroob kunnen worden afgebroken. Alleen stoffen die anaëroob worden afgebroken doorstaan deze stap. Indien een covergistingsmateriaal in hoofdzaak uit organische stof bestaat die zeer makkelijk anaëroob wordt afgebroken, bv. suiker, dan is zo'n covergistingsmateriaal in het algemeen niet geschikt voor vergisting, omdat het risico van verzuring met als gevolg afdoding van de methaanvormende bacteriën te groot is. Verwerking van suikerhoudende reststromen vraagt derhalve aanpassing van het rantsoen (laag aandeel in het dagelijkse rantsoen van een vergistingsinstallatie). Op het aandeel in het rantsoen wordt bij stap 5 terug gekomen.

Ook andere stoffen kunnen de biogasproductie remmen of ontregelen. Hoge gehalten aan ammoniumstikstof, kalium en chloride remmen de biogasproductie. Covergistingsmaterialen met hoge gehalten aan genoemde stoffen vragen aanpassing van het rantsoen. Dergelijke vormen van aanpassingen zijn niet betrokken in dit onderzoek, deze aanpassingen vragen expertise van de ondernemer met een vergistingsinstallatie.

\footnotetext{
${ }^{6}$ http://www.wageningenur.nl/nl/Expertises-Dienstverlening/Wettelijke-Onderzoekstaken/WOT-Natuur-en-Milieu/Publicaties-WOT-NatuurMilieu/Show.htm?publicationId=publication-way-333835383537
} 


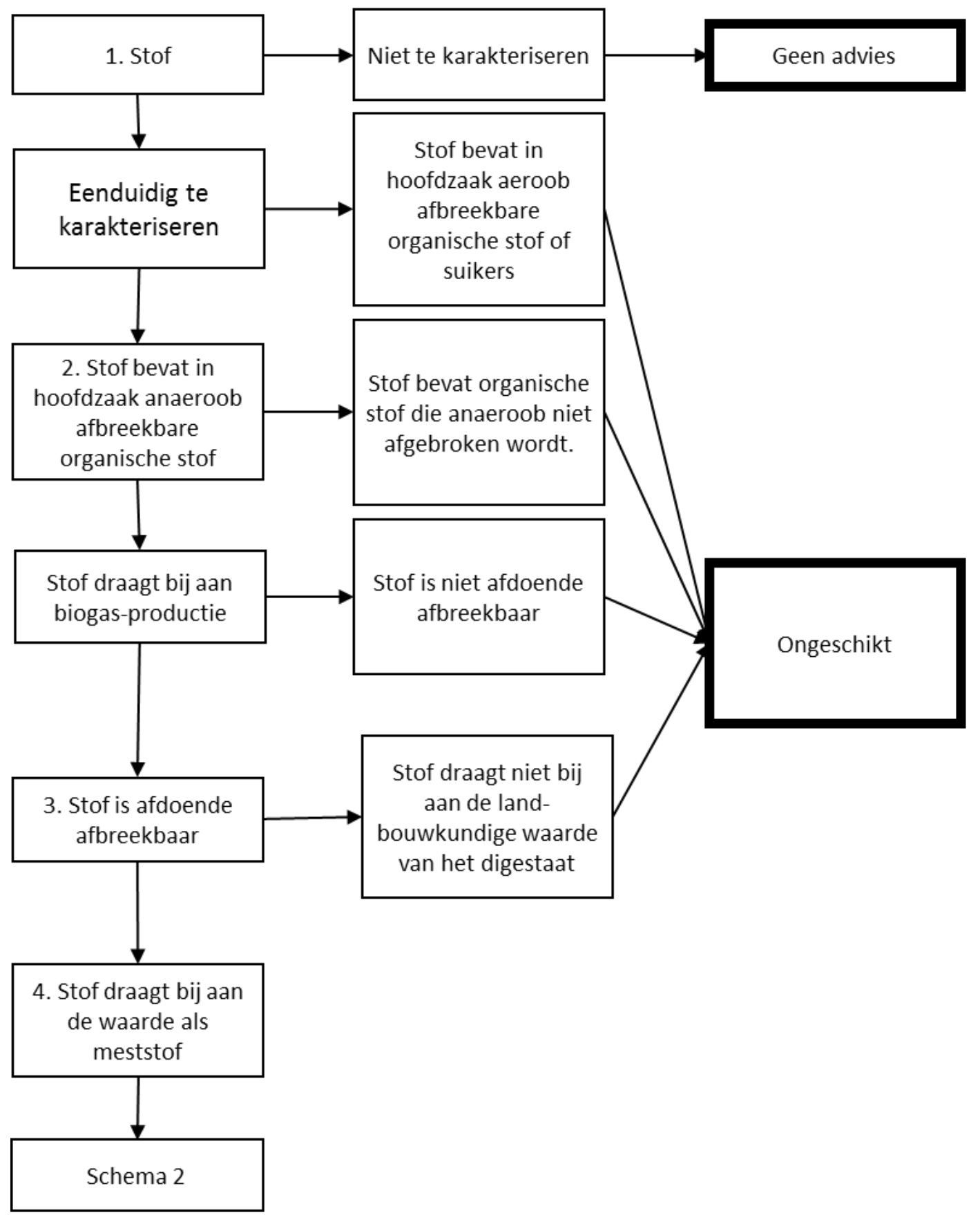

Schema 1. Stappenplan toetsing van stoffen op geschiktheid als covergistingsmateriaal op basis van expert judgement voor criteria 1 tot en met 4.

$\mathrm{Er}$ is afgeweken van het Protocol betreffende het criterium over de bijdrage aan de biogasproductie. Het Protocol schrijft voor dat die tenminste gelijk moet zijn aan de biogasproductie van dierlijke mest. Waterige afval- en reststoffen die lagere drogestofgehaltes en organische stofgehaltes hebben, leveren lagere biogasproducties vergeleken met dierlijke mest. Dit is niet als bezwaarlijk aangemerkt. Dergelijke waterige afval- en reststoffen kunnen functioneel zijn ingeval het rantsoen ook uit droge covergistingsmaterialen bestaat. Verdunning met water is dan nodig om vergisting mogelijk te maken om het verpompbaar materiaal te verkrijgen dat geschikt is voor natte vergisting.

Stap 3 (schema 1). Het residu van vergisting (anders dan contaminanten) dient geen landbouwkundige belemmering op te werpen. Voorbeelden van residuen zijn vetten (maken de bodem hydrofoob), plastic en zwerfafval. Indien milieuhygiënisch ongewenste residuen aanwezig zijn, dan doorstaat de stof deze stap niet. Vetten (hieronder ook oliën) kunnen anaëroob afgebroken worden en dragen dan bij aan de biogasproductie door verhoging van de gaskwaliteit (hoger aandeel methaan) en door een hogere productie. Dit vraagt een goed geleid vergistingsproces met een voldoend lange verblijftijd in de reactor en vetsoorten die zich hiervoor lenen. 
Stap 4 (schema 1). Het digestaat dient een landbouwkundig acceptabele samenstelling te hebben. Die samenstelling wordt bepaald bij een mengverhouding van dierlijke mest ten opzichte van de stof van 50\%:50\% (gewichtsprocenten) en bij monovergisting van die stof (100\%). Indien de samenstelling van het digestaat dusdanig gaat afwijken van die van dierlijke mest en de gift aan waardegevende bestanddelen zeer hoge giften of zeer geringe giften aan digestaat vraagt die niet passen bij de huidige landbouwpraktijk, dan doorstaat de stof deze stap niet.

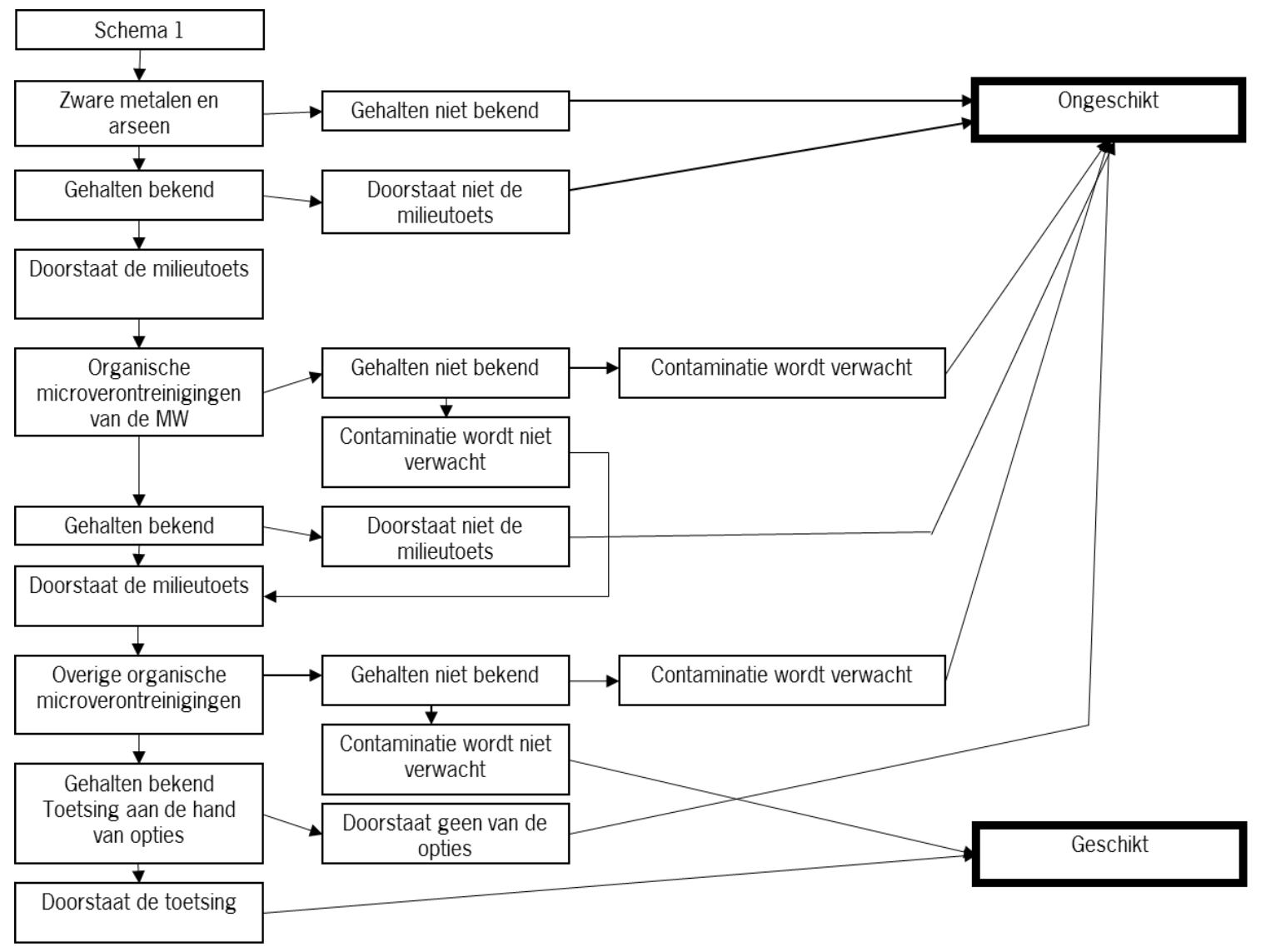

Schema 2. Stappenplan toetsing van stoffen op geschiktheid als covergistingsmateriaal op basis van expert judgement voor criterium 5 voor beoordeling van anorganische contaminanten (zware metalen en arseen), organische contaminanten van de Meststoffenwet en overige organische contaminanten (= residuen van gewasbeschermingsmiddelen en biociden).

Stap 5 (Schema 2). In deze stap wordt bepaald of het digestaat van vergisting van de stof in combinatie met dierlijke mest leidt tot een 'schoon en onverdacht' digestaat, waardoor er geen ongewenst hoge contaminatie van de bodem zal optreden. Deze stap kent drie onderdelen:

a. Beoordeling van de zware metalen cadmium, chroom, koper, kwik, nikkel, lood, zink en van arseen. Gegevens van zware metalen en arseen dienen beschikbaar te zijn om te komen tot een verantwoorde beoordeling, tenzij aannemelijk gemaakt kan worden dat gehalten niet in zorgvragende orde van grootte aanwezig kunnen zijn. Getoetst wordt aan de jaarvracht die toegelaten is met zuiveringsslib. Deze jaarvracht wordt afgeleid uit de maximaal jaarlijks toegestane dosering van 2 ton drogestof per ha en de maximaal toelaatbare gehalten aan zware metalen en arseen in zuiveringsslib ${ }^{7}$. Deze jaarvracht vormt de grondslag voor de samenstellingseisen die aan meststoffen gesteld wordt in UBMW en URMW.

b. Vervolgens wordt bepaald of de stof zorgvragende gehalten aan in de Meststoffenwet benoemde organische contaminanten bevat. Deze contaminanten zijn $\Sigma \mathrm{PCDD} / \mathrm{PCDF}, \mathrm{a}-\mathrm{HCH}, \beta-\mathrm{HCH}, \mathrm{Y}-\mathrm{HCH}$

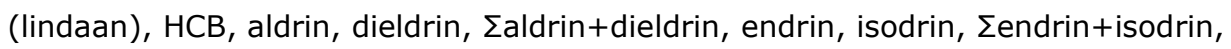

${ }^{7}$ Bijlage II, Tabel 2 van het Uitvoeringsbesluit Meststoffenwet 


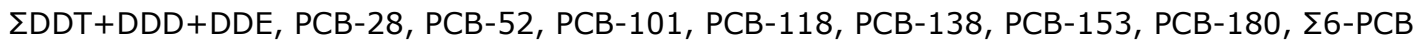
(excl. PCB-118), naftaleen, fenantreen, anthraceen, fluorantheen, benzo(a)anthraceen, chryseen, benzo(k)fluorantheen, benzo(a)pyreen, benzo( $g, h, i)$ peryleen, indeno(1,2,3-c,d)pyreen, $\Sigma 10-P A K$ en minerale olie. Getoetst wordt aan de jaarvracht die het ministerie LNV heeft vastgesteld voor deze organische contaminanten op basis van het onderzoek van Olde Venterink en Linders (1994). Deze jaarvracht vormt de basis voor de samenstellingseisen van meststoffen die opgenomen zijn in het UBMW en de URMW. Als een stof een verbrandingsfase kent zal bijvoorbeeld tenminste adequate informatie over gehalten aan PAK's beschikbaar moeten zijn; bij vetten (inclusief oliën) is dan informatie over gehalten aan dioxines en PCB's noodzakelijk. Daarentegen kan het ontbreken van enig meetgegeven niet opgevat worden als een belemmering, wanneer op basis van expert judgement beredeneerd kan worden dat een bepaald contaminant niet aanwezig hoeft te zijn. Dit is bijvoorbeeld het geval bij chloorhoudende gewasbeschermingsmiddelen (a- $\mathrm{HCH}, \beta-$

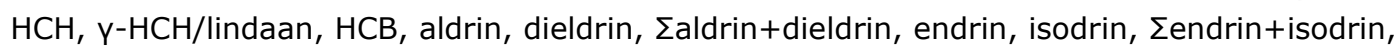
$\Sigma D D T+D D D+D D E)$. Deze middelen worden niet meer toegepast in de $\mathrm{EU}^{8}$ en zijn uitgefaseerd. Meetgegevens van deze actieve stoffen betreffen altijd een detectielimiet. Afhankelijk van het uitvoerend laboratorium hebben de detectielimieten een onderscheidenlijk niveau (bv. 0,01 of $0,005 \mathrm{mg} / \mathrm{kg}$ ). De hogere detectielimieten kunnen aanleiding zijn voor de berekening van een normoverschrijdende vracht. Aan dergelijke berekeningsresultaten wordt bij dit onderzoek geen betekenis gegeven. Het uitgangspunt is dat, omdat deze gewasbeschermingsmiddelen verboden zijn, er geen nader onderzoek nodig is. Indien stappen a en b uitwijzen dat de stof die onderdelen van de milieutoets doorstaat, dan volgt c:

c. Toetsing van de overige organische contaminanten (OOM: residuen van gewasbeschermingsmiddelen en biociden). De uitwerking van deze stap wordt gegeven in de volgende paragraaf.

\subsection{OOM, protocol en alternatieven}

In dit onderzoek is het protocol gevolgd en daarnaast zijn door het RIVM drie alternatieven voor toetsing voor de vracht aan residuen van OOM opgesteld met de beoordelingssystematiek volgens Van Dijk et al. (2009) als referentie. Er zijn vier scenario's opgesteld. Een scenario legt restricties op aan de maximaal toegelaten concentratie van een residu van een OOM in samenhang met de snelheid van afbraak. De vier scenario's zijn:

1. Het protocol versie 2.1 (Van Dijk et al., 2009) waarin de concentratie in landbouwgrond nooit het niveau van VR zal overschrijden $\left(\mathrm{C}_{\max }=\mathrm{VR}\right)$;

2. Alternatief 1 , waarin de concentratie in landbouwgrond nooit het niveau van MTR zal overschrijden $\left(C_{\max }=M T R\right)$, maar waarbij voor relatief persistente werkzame stoffen de concentratie in de landbouwbodem na een jaar (kort voor de volgende digestaatgift) hoger (zelfs aanzienlijk hoger) kan zijn dan het niveau van VR;

3. Alternatief 2, waarin de concentratie in landbouwgrond nooit het MTR niveau met meer dan een factor $10 \mathrm{zal}$ overschrijden $\left(\mathrm{C}_{\max } \leq 10\right.$.MTR) maar waarin een jaar na de digestaatgift de concentratie van de werkzame stof altijd gedaald is tot het niveau van VR $\left(\mathrm{C}_{\min }=\mathrm{VR}\right)$;

4. Alternatief 3 , waarin de concentratie in landbouwgrond nooit het MTR-niveau $\left(C_{\max } \leq M T R\right)$ zal overschrijden, maar waarin een jaar na de digestaatgift de concentratie van de werkzame stof altijd gedaald is tot het niveau van VR $\left(C_{\min }=M T R\right)$.

De vracht aan residu wordt afgeleid uit meetwaarden of geschat uit gegevens over toegelaten dosering en geschatte biomassa opbrengst en verdeling over de biomassa. Berekend wordt welk gehalte aan OOM resteert in de bodem of het grondwater na één jaar volgens één van de scenario's. Deze toetsing kan leiden tot de volgende resultaten voor de concentratie in de bodem:

1. Stof doorstaat toetsing van de concentratie aan VR.

2. Stof doorstaat toetsing van de concentratie aan MTR.

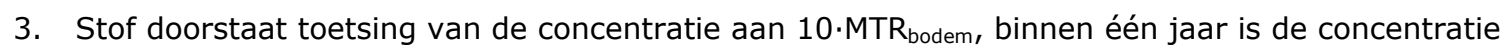
gedaald tot VR.

\footnotetext{
${ }^{8}$ Buiten de EU27 vindt toepassing van $\mathrm{Cl}$-houdende pesticiden nog wel plaats.
} 
4. Stof doorstaat toetsing van de concentratie aan MTR, binnen één jaar is de concentratie gedaald tot VR.

5. Stof doorstaat geen van bovenstaande scenario's.

In alle scenario's word de concentratie in het grondwater beoordeeld volgens het protocol versie 2.1

(Van Dijk et al., 2009).

Resultaat I leidt tot positief advies, resultaat $\mathrm{V}$ tot negatief advies. Resultaten II, III en IV vragen beleidsafweging; er wordt afgeweken van het Protocol. Bijlage 5 geeft de volledige verantwoording. Een covergistingsmateriaal dat met minder dan $5 \%$ van het rantsoen wordt vergist, wordt op eenzelfde grondslag beoordeeld als een stof die $50 \%$ van het rantsoen uitmaakt. Bij expert judgement wordt niet betrokken welk aandeel van een verontreinigde stof in het rantsoen van de vergister aanwezig mag zijn om het digestaat nog schoon en overdacht te doen zijn.

Het aantal bestudeerde actieve stoffen van OOM is in dit onderzoek beperkt tot 10 in verband met beschikbare tijd en menskracht. De stoffen zijn, in goed overleg, aangewezen door de ministeries van EL\&I en I\&M. Hierbij is een top down benadering gevolgd: prioriteit wordt gegeven aan stoffen waarvan de frequentie van voorkomen afneemt, de maximale vracht toeneemt en het quotiënt van het jaarlijks gebruiksvolume en de maximale vracht afneemt. Bijlage 5 verantwoordt deze selectie van actieve stoffen. De geselecteerde actieve stoffen worden gegeven in Tabel 1.

\section{Tabel 1}

Geselecteerde actieve stoffen (RIVM, bijlage 5, Tabel B5.1).

\begin{tabular}{lll} 
Nr. & Actieve stof & Toepassing \\
\hline 1 & metsulfuron-methyl & Land \\
\hline 2 & metribuzin & Land \\
\hline 3 & pirimifos-methyl & Opslag \\
\hline 5 & deltamethrin & Land \\
\hline 6 & mancozeb & Land/Opslag \\
\hline 8 & lambda-cyhalothrin & Land \\
\hline 9 & fenmedifam & Land \\
\hline 10 & MCPA & Land \\
\hline
\end{tabular}

\subsection{Betekenis van de alternatieven ten opzichte van het protocol}

De betekenis van de beoordelingswijze van meststoffen en co-vergistingsmaterialen volgens het protocol en de drie beschreven alternatieven in relatie tot het voorkómen van risico's voor mens en milieu wordt in deze paragraaf nader uitgewerkt.

\subsubsection{Protocol versie 2.1}

Bij het huidige protocol mag de concentratie van een stof in de bouwvoor bij veeljarige toediening van meststoffen maximaal het $\mathrm{VR}^{9}$ bedragen op het moment van toediening. Het VR is afgeleid van het MTR: het Maximaal Toelaatbaar Risiconiveau. Het MTR-niveau voor bodem wordt bepaald door de

\footnotetext{
${ }^{9}$ Voor de organische microverontreinigingen, die reeds genormeerd zijn in het kader van de Meststoffenwet, sprake van een maximaal niveau van $4 *$ MTR als gevolg van een destijds gehanteerde beleidsmatige verhoging. Voor deze studie naar niet-genormeerde stoffen is echter het VR-niveau aangehouden.
} 
laagste waarde van MTR-waarden ${ }^{10}$ voor de mens en voor het ecosysteem (VROM, 2004). De mens kan indirect worden blootgesteld via het eten van gewassen of daaruit geproduceerde levensmiddelen, of door consumptie van melk- of vleesproducten van dieren die stoffen via voedsel uit de grond hebben opgenomen. Het ecosysteem omvat zowel de micro-organismen, dieren en planten die in of op de bodem leven, als vogels en zoogdieren die bodemdieren als voedsel gebruiken. Het MTR dekt al deze routes af. Het VR ligt aanzienlijk lager dan het MTR (namelijk 1/100 van het MTR (behalve voor stoffen met een natuurlijke achtergrondconcentratie)) en geeft daardoor een veel hoger beschermingsniveau. De factor 100 tussen MTR en VR is gekozen, omdat in het milieu vele stoffen tegelijkertijd kunnen worden aangetroffen. Het VR is met name bedoeld om rekening te houden met de mogelijke effecten van combinatietoxiciteit ten gevolge van het tegelijkertijd aanwezig zijn van vele stoffen. Bij de beoordeling van covergistingsmaterialen volgens Protocol versie 2.1 wordt dus het meest stringente risiconiveau gehanteerd, zodat de kans op negatieve effecten op mens en ecosysteem door het tegelijkertijd aanwezig zijn van meerdere stoffen in de bodem te verwaarlozen is.

Het VR-niveau, zoals voor sommige stoffen vastgelegd in de vorm van de streefwaarde, voor grond/sediment heeft ook een nadrukkelijke rol binnen het preventieve beleid ter voorkoming van bodemverontreiniging, vooral het beleid dat zich richt op diffuse bronnen (VROM, 2008).

In dit rapport wordt met de milieutoets volgens het protocol de benadering bij toepassing van het VR bedoeld zoals hierboven is toegelicht. Ten opzichte van het geldende protocol is op één punt afgeweken. Uitgegaan is van de maximaal toelaatbare vracht onder in achtneming van de mengverhouding van $50 \%$ dierlijke mest en $50 \%$ covergistingsmateriaal in het rantsoen voor de vergister.

\subsubsection{Alternatief 1}

Bij alternatief 1 mag de concentratie van een stof in de bouwvoor bij veeljarige toediening van meststoffen maximaal het MTR bedragen op het moment van toediening. Dit houdt dus een 100x minder strenge beoordeling in dan volgens het Protocol. Voor snel afbreekbare stoffen zullen de bodemconcentraties snel dalen: binnen een jaar tot (ver) beneden het VR. Voor persistentere stoffen geldt dit echter niet. Bij dit alternatief kunnen dus meerdere stoffen op het moment van toediening aanwezig zijn op MTR-niveau en er is geen garantie dat alle concentraties voor het volgende seizoen onder het VR liggen.

\subsubsection{Alternatief 2}

Alternatief 2 garandeert dat alle stoffen 1 jaar na toediening weer tenminste het VR-niveau hebben bereikt, maar de maximale bodemconcentratie mag op het moment van toediening maximaal $10 * M T R$ bedragen. In de methodiek van de MTR-afleiding wordt voor het ecosysteem (ecotoxicologische effecten) als laagste veilligheidsfactor een waarde van 10 gehanteerd ten opzichte van de laagste concentratie waarbij in chronische toetsen geen effecten worden waargenomen bij de bestudeerde testorganismen. Het niveau van 10*MTR komt in die situatie overeen met het laagst bekende NoObservered-Effect-Concentration, maar biedt geen garantie voor het afwezig zijn van ontoelaatbare risico's voor niet-geteste soorten of processen. Dit betekent dat er bij toepassing van dit alternatief een hogere kans aanwezig is dat er ongewenste/ontoelaatbare effecten kunnen optreden als gevolg van toepassing van meststoffen en covergistingsmaterialen. De omvang hiervan wordt bepaald door de gevoeligheid van de potentieel aanwezige soorten voor een specifieke stof: de zogenaamde species-sensitivity distribution (SSD). Dit is de gevoeligheidsverdeling van de soorten als functie van de concentratie van de stof, die gebruikt wordt voor de MTR-afleiding als er toxiciteitsgegevens voor voldoende soorten van verschillende taxonomische groepen beschikbaar zijn (zie Tekstbox met Figuur 1). Het MTR is dan gelijk aan de concentratie waarbij $5 \%$ van de soorten mogelijk nadelige effecten ondervindt ( de $\mathrm{HC}_{5}$-waarde ${ }^{11}$ ). Bij een vlakke SSD-curve beïnvloedt een overschrijdingsfactor 10 van het MTR verhoudingsgewijs minder extra soorten op negatieve wijze dan bij een veel steilere curve.

\footnotetext{
${ }^{10}$ Voor de mens is het maximale risiconiveau gedefinieerd als de concentratie van een stof waarbeneden geen negatief effect te verwachten is. Voor het ecosysteem is dit de concentratie waarbeneden $95 \%$ van de potentieel aanwezige soorten in een ecosysteem zijn beschermd.

${ }^{11}$ Hazardous concentration voor $5 \%$ van de organismen.
} 
Het MTR voor bodem wordt echter vrijwel nooit op de SSD-curve gebaseerd, omdat de dataset vaak niet voldoet aan de eisen wat betreft aantal en soort gegevens.

\section{Tekstbox 1: Gevoeligheid van organismen voor chemische stoffen}

Organismen verschillen in gevoeligheid wanneer ze blootgesteld worden aan een chemische stof.

Ecotoxicologen maken hier dankbaar gebruik van bij het schatten van de "potentieel aangetaste fractie" van soorten. De NOEC's (No-Observed-Effect-Concentration) verkregen in chronische laboratoriumtoetsen ter bepaling van de toxiciteit van een chemische stof zijn lognormaal verdeeld (figuur 1, bovenste figuur, de waarschijnlijkheidsdichtheid uitgezet tegen log NOEC laat een normale verdeling zien). Dikwijls wordt een dergelijke verdeling aangeduid met de term gevoeligheidsverdeling (species sensitivity distribution, SSD). De breedte van die klokvormige curve hangt af van het werkingsmechanisme van de chemische stof in kwestie. De figuur laat zien dat bij chemicaliën met een niet-specifieke toxische werking, zoals bij narcotisch werkende chemicaliën, de verdeling smal is. Bij specifiek werkende stoffen, zoals pesticiden, is de verdeling breed. De figuur toont de dichtheidsfunctie voor twee hypothetische stoffen met dezelfde $\mathrm{HC}_{50}$ (concentratie waarbij 50 $\%$ van de soorten geen effect ondervindt, het midden van de verdeling). De ene stof heeft een niet-specifieke werking, de andere is een specifiek werkende stof, een pesticide. De onderste figuur, de cumulatieve van de dichtheidsfunctie, laat de implicatie hiervan zien. Deze cumulatieve functie wordt ook wel de Potentieel Aangetaste Fractie van soorten (PAF) genoemd. De MTR ( $\mathrm{HC}_{5}$, ofwel de concentratie waarbij $5 \%$ van de soorten niet is beschermd) van het pesticide is veel lager dan die van de niet specifiek werkende stof omdat voor een pesticide de gevoeligheidsverdeling zo breed is. Een andere implicatie is dat indien de MTR overschreden wordt, zoals in de figuur met een factor 3, dit voor een specifiek werkende chemische stof (brede verdeling) beperkte gevolgen heeft: PAF wordt verhoogd van $5 \%$ naar $10 \%$. Zoals de figuur laat zien, zijn de consequenties bij een stof met een smalle verdeling ernstiger. Bij een concentratie van 3 keer MTR worden maar liefst $25 \%$ van de soorten niet meer beschermd.

Samengevat: 1) de MTR van een specifiek werkende stof afgeleid uit een brede gevoeligheidsverdeling ligt lager dan bij een niet-specifiek werkende stof met een gelijke mediaan van laboratoriumdata (HC50) (bovenste figuur). 2) wanneer het beschermingsniveau (MTR) overschreden wordt, zijn de consequenties minder ernstig voor een stof met een brede gevoeligheidsverdeling (onderste figuur).
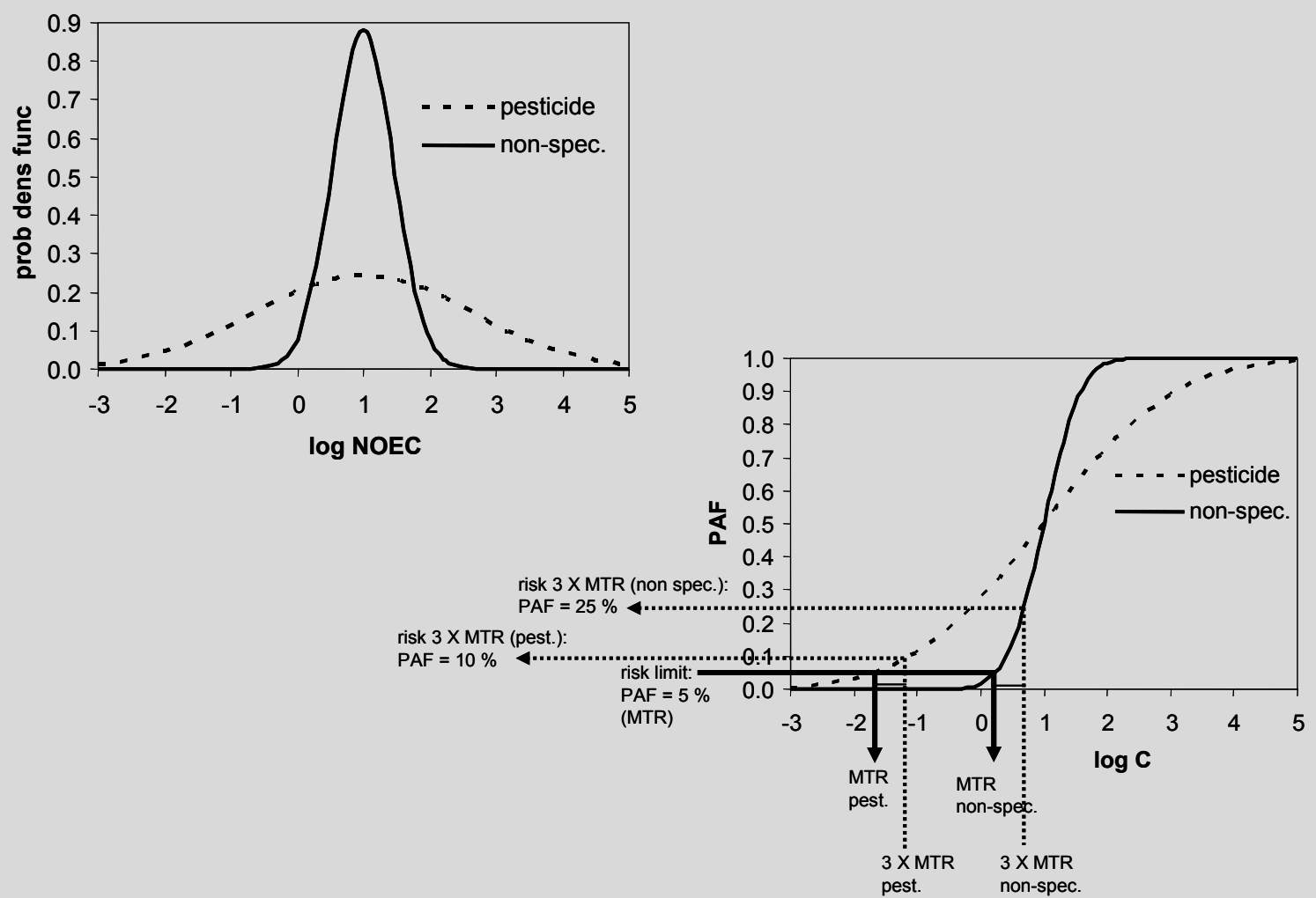

Figuur 1. Boven: gevoeligheidsverdeling van soorten (SSD) voor twee chemische stoffen met verschillende werkingsmechanismen: een specifiek werkende stof (pesticide) en een niet-specifiek werkende stof.

Onder: de cumulatieve gevoeligheidsverdeling, waarbij de potentieel aangetaste fractie van soorten (PAF) is uitgezet tegen de logaritme van de concentratie van een chemische stof. 


\subsubsection{Alternatief 3}

Alternatief 3 is een modificatie van alternatief 2 : bij toediening mag de concentratie van een stof in de bouwvoor bij veeljarige toediening van meststoffen maximaal het MTR bedragen, maar binnen 1 jaar na toediening moet het VR zijn bereikt. Bij alternatief 3 is er - in tegenstelling tot alternatief 2 sprake van een dubbele garantie ten aanzien van de risiconiveaus bij het toedienen van meststoffen: immers, de concentratie van stoffen in de bodem zal nooit het MTR-niveau overschrijden en binnen een 1 jaar na toediening wordt minimaal het VR-niveau bereikt.

\subsubsection{Overwegingen bij de drie gepresenteerde alternatieven}

Als meerdere stoffen gedurende een jaar tegelijkertijd voorkomen in het milieu in een concentratie beneden het VR, dan wordt aangenomen dat het gemeenschappelijke effect van de stoffen verwaarloosbaar is. Als daarentegen de concentratie van meerdere stoffen gedurende een jaar ter hoogte van het MTR of hoger ligt, dan kunnen negatieve effecten ten gevolge van het tegelijkertijd voorkomen van de stoffen niet worden uitgesloten. Bij de risicobeoordeling voor toelating van stoffen, zoals gewasbeschermingsmiddelen, worden stoffen namelijk individueel beoordeeld op hun risico's voor mens en milieu en wordt het gelijktijdig voorkomen van actieve stoffen niet in ogenschouw genomen. De beoordeling volgens Protocol versie 2.1 doet dit dus wel.

Van de gepresenteerde alternatieven sluiten alternatief 2 en 3 het beste bij de bestaande methode aan, nl. dat binnen 1 jaar het VR bereikt moet zijn. Deze alternatieven bieden enige ruimte voor stoffen die snel afbreken. Voor persistente stoffen maakt deze verschuiving niet of nauwelijks verschil. Doordat er bij alternatief 3 nooit sprake zal zijn van overschrijding van het MTR ten gevolge van het toedienen van meststoffen, levert dit alternatief de beste garanties op het voorkomen van ongewenste effecten in vergelijking met de andere alternatieven ${ }^{12}$. Omdat bij alternatief 2 stoffen namelijk (gedurende een deel van het jaar) boven het MTR mogen voorkomen als gevolg van toediening van meststoffen, kan het optreden van ongewenste effecten niet geheel worden uitgesloten; temeer omdat aanvullende belasting van de bodem via andere routes kan plaatsvinden, waaronder het gebruik van gewasbeschermingsmiddelen.

Alternatief 1 biedt de meeste ruimte voor contaminanten, omdat er geen eis opgenomen is wanneer het VR bereikt moet zijn. Wel kan het zijn dat de voorspelde belasting van het grondwater eerder beperkend is dan de belasting van de bodem.

Schade aan volggewassen is een punt van aandacht voor de beoordeling. Blootstelling aan een mix van stoffen vlakbij of boven het MTR niveau kan leiden tot gewasschade. Herbiciden zijn hiervan een aansprekend voorbeeld. Daarom is het noodzakelijk voor contaminanten, waarvoor dit een rol kan spelen, opnieuw het MTR af te leiden of te herevalueren, specifiek met het oog op fytotoxiciteit, ook als er dus al MTR-waarden zijn afgeleid of vastgesteld.

Nadrukkelijk moet nog eens gemeld worden dat voor alle hiervoor genoemde beoordelingswijzen (zowel volgens het Protocol als volgens de 3 alternatieven) geldt dat alleen de belasting van de bodem via de meststof of het covergistingsmateriaal in ogenschouw is genomen. Dit betekent dat andere mogelijke belastingsroutes van de bodem (zoals gebruik van gewasbeschermingsmiddelen) een (aanzienlijke) extra belasting teweeg kunnen brengen, die geen onderdeel vormt van de beoordelingsmethodiek. Vandaar dat een zekere terughoudendheid ten aanzien van het toelaatbaar achten van hogere vrachten ten gevolge van stoffen in meststoffen of co-vergistingsmaterialen wenselijk is.

\footnotetext{
${ }^{12}$ De eventuele bijdrage via andere bronnen (bv. toepassing van gewasbeschermingsmiddelen en atmosferische depositie) is hierbij niet in ogenschouw genomen.
} 


\subsubsection{Afbakening bij expert judgement}

Bij het oordeel op basis van expert judgement is daarnaast een aantal aspecten niet betrokken bij de afweging. Dit betreft onder meer:

- Er moest afgeweken worden van het voorschrift van het Protocol over meetgegevens betreffende analysemethode en de accreditatie van het uitvoerend laboratorium. De in data- en literatuurbestanden aangetroffen meetwaarden van waardegevende bestanddelen en contaminanten zijn overgenomen. Er is geen weging uitgevoerd of de meetwaarden verkregen zijn door toepassing van door de Meststoffenwet aangewezen analysemethoden. Veelal ontbreekt informatie of het uitvoerende laboratorium geaccrediteerd is.

- $\quad$ Er zijn enkele stoffen die zeer goed voorzien zijn van gegevens over de samenstelling maar over de meeste stoffen zijn weinig meetgegevens beschikbaar. Bij laatstgenoemde stoffen is daardoor geen verantwoord beeld te geven over de aanwezige spreiding in gehalten van waardegevende bestanddelen en gehalten van contaminanten. Bij de aanwezigheid van veel gegevens is er een grotere kans op de aanwezigheid van een gehalte aan een contaminant dat een norm overschrijdt. Dit leidt tot een ongelijke weging bij het opstellen van een oordeel over een stof. Het uitgangspunt bij het opstellen van het oordeel is daarom het gemiddelde van alle metingen van een contaminant. Er wordt wel inzicht gegeven in de voorkomende spreiding van een contaminant en de betekenis daarvan bij het uitvoeren van de milieutoets (risicobeoordeling contaminanten). Daardoor wordt afgeweken van het Protocol dat gebaseerd is op een worst-case scenario, dat wil zeggen dat er getoetst wordt op de maximaal voorkomende belasting. Het ontbreken van verantwoorde meetgegevens bij aangemelde stoffen blijft een knelpunt.

- Sanitatie-aspecten zijn niet betrokken bij de beoordeling anders dan de verplichting die voortkomt uit de EG-Verordening voor dierlijke bijproducten. Ten tijde van het schrijven van dit rapport is in Duitsland, mede door de zoektocht naar de oorzaken voor de besmetting met de EHEC-bacterie, een discussie gestart over de risico's verbonden aan vergistingsinstallaties inzake E. coli ${ }^{13}$ en botulisme. Op deze discussie wordt hier niet verder ingegaan.

- Afval- en reststoffen kunnen zwavelverbindingen bevatten waardoor de gaskwaliteit slechter wordt door een verhoging van het gehalte aan $\mathrm{H}_{2} \mathrm{~S}^{14}$. Dit aspect is niet betrokken in het opstellen van de beoordeling. Ook kunnen afval- en reststoffen eiwitrijk zijn, waardoor bij vergisting het gehalte aan ammoniumstikstof zo hoog wordt dat het de productie van methaan remt. Het gebruik van zwavelhoudende en eiwitrijke afval- en reststoffen vraagt aanpassing van het rantsoen. Deze aanpassingen vormen geen onderdeel van deze studie en worden niet betrokken in een oordeel over een stof.

\footnotetext{
${ }^{13}$ http://www.biogas.org/edcom/webfvb.nsf/id/DE_Informationspapier_EHEC/\$file/11-06-06_EHEC.pdf

${ }^{14} \mathrm{Bij}$ verbranding wordt zwavelzuur gevormd hetgeen aanleiding kan geven tot corrosie van de verbrandingsmotor.
} 



\section{$4 \quad$ Beoordeling van de stoffen}

\section{$4.1 \quad$ Inleiding}

De beoordeling van de stoffen vereist informatie over de waardegevende bestanddelen stikstof, fosfaat, organische stof en drogestof en de gehalten aan anorganische en organische microverontreinigingen. Koffiedik is de enige stof waarbij tijdig en adequaat gevraagde informatie volledig werd aangeleverd. Enkele andere stoffen (hooi, cigarant, bietenperspulp) werden voorzien van een deel van de gevraagde gegevens. In het algemeen ontbrak enige vorm van gegevensverstrekking door belanghebbenden of was dit onvolkomen. Om toch tot risicobeoordeling te kunnen overgaan, werd daarop bronnenonderzoek uitgevoerd. Bij dit bronnenonderzoek werden gegevens betrokken die afkomstig zijn van eerder ingediende verzoeken voor opname van afval- en reststoffen als covergistingsmateriaal in bijlage Aa van de URMW. Deze gegevens zijn afkomstig van gegevensformulieren (CoVe) die werden ingediend bij het ministerie LNV Directie Kennis en Innovatie (DKI) en van verzoeken die ingediend werden bij het ministerie LNV Dienst Regelingen (DR, nu RVO.NL) te Assen. Daarnaast zijn gegevens van internet en uit de catalogus van WUR (bibliotheek) verzameld. In het algemeen was datamontage noodzakelijk. Dat wil zeggen dat gegevens van diverse herkomst samengebracht werden tot één gegevensbestand. Een overzicht van de verzamelde gegevens wordt gegeven in bijlage 6. De herkomst van de gegevens wordt verantwoord bij de bronvermelding gegeven bij de literatuur.

Tabel 2 geeft een overzicht van de stoffen die beoordeeld zijn en de herkomst van de gegevens.

\section{Tabel 2}

Overzicht van de gegevensverzameling bij de dossiers.

\begin{tabular}{|c|c|c|c|}
\hline Nr. & Dossiers & Onderverdeling & Stof \\
\hline \multirow[t]{2}{*}{1} & \multirow[t]{2}{*}{ Zonnebloemen } & $1 a$ & Zonnebloempitten/zaden \\
\hline & & $1 b$ & Geëxtraheerd zonnebloemmeel \\
\hline \multirow[t]{12}{*}{2} & \multirow[t]{12}{*}{ Bermgras } & $2 a$ & Bermgras Borculo \\
\hline & & $2 b$ & Bermgras Eibergen \\
\hline & & $2 c$ & Bermgras Apeldoorn \\
\hline & & $2 d$ & Bermgras Regge \& Dinkel \\
\hline & & $2 e$ & Bermgras Dinkelland \\
\hline & & $2 f$ & Bermgras Overijssel \\
\hline & & $2 g$ & Bermgras Hof van Twente \\
\hline & & $2 \mathrm{~h}$ & Bermgras Noord-Brabant \\
\hline & & $2 \mathrm{i}$ & Bermgras Noord-Holland \\
\hline & & $2 \mathrm{j}$ & Slootmaaisel \\
\hline & & $2 \mathrm{k}$ & Bermgras van plattelandswegen \\
\hline & & 21 & Beheersgras/natuurgras \\
\hline 3 & Hooi & 3 & Hooi \\
\hline 4 & Stro van koolzaad & 4 & Stro van koolzaad \\
\hline 5 & Tarwe & 5 & Tarwe (Triticale) \\
\hline 6 & Erwten & 6 & Erwt \\
\hline 7 & Maïs & 7 & Maïs (positieve lijst) \\
\hline 8 & $\begin{array}{l}\text { Maïssilage van hele planten (dit vooral } \\
\text { voor biologische bedrijven) }\end{array}$ & 8 & Mais (silage van hele planten, positieve lijst) \\
\hline 9 & Beheersgras & 9 & Beheersgras/natuurgras \\
\hline \multirow[t]{2}{*}{10} & \multirow[t]{2}{*}{ Bakkerijrestproducten/koekmix } & $10 a$ & $\begin{array}{l}\text { Bakkerijrestproducten (brood- en } \\
\text { deegresten) }\end{array}$ \\
\hline & & $10 b$ & Retour brood bakkerijen \\
\hline
\end{tabular}




\begin{tabular}{|c|c|c|c|}
\hline \multirow[t]{5}{*}{ Nr. } & \multirow[t]{5}{*}{ Dossiers } & \multirow{2}{*}{$\begin{array}{l}\text { Onderverdeling } \\
\text { 10c }\end{array}$} & \multirow{2}{*}{$\begin{array}{l}\text { Stof } \\
\text { Broodproducten }\end{array}$} \\
\hline & & & \\
\hline & & $10 \mathrm{~d}$ & Deeg \\
\hline & & $10 \mathrm{e}$ & Brood en brooddeeg \\
\hline & & $10 f$ & Brood en brooddeeg \\
\hline 11 & Sojasuiker & 11 & Sojasuiker \\
\hline \multirow{4}{*}{12} & \multirow{4}{*}{ Uienpulp } & $12 b$ & Zilveruien \\
\hline & & $12 \mathrm{c}$ & Bio energy onion \\
\hline & & $12 d$ & Uiensap \\
\hline & & $12 \mathrm{e}$ & Uienpulp \\
\hline 14 & Bierbostel & 14 & Gerstsubstraat (Bierbostel) \\
\hline 15 & Maïsgluten & 15 & Maïsgluten \\
\hline 16 & Melasse (slib) & 16 & Melasse (slib) \\
\hline 17 & Raapschroot & 17 & Raapzaadschroot \\
\hline 18 & Perspulp van cichoreiwortelen (Cigarant) & 18 & Cigarant \\
\hline \multirow[t]{2}{*}{19} & \multirow[t]{2}{*}{ Wei } & $19 a$ & Weipoeder derivaten (SCAL) \\
\hline & & $19 b$ & Weipoeder (Denkavit) \\
\hline \multirow{4}{*}{21} & \multirow{4}{*}{$\begin{array}{l}\text { Bloembollen + Afval van sorteren van } \\
\text { bloembollen }\end{array}$} & $21 b$ & Tulp-veld \\
\hline & & $21 c$ & Lelie-broeierij \\
\hline & & $21 d$ & Lelieveld \\
\hline & & $21 \mathrm{e}$ & Gladiool \\
\hline 22 & Glycerine van dierlijke herkomst & 22 & Glycerine van dierlijke oorsprong \\
\hline \multirow[t]{6}{*}{23} & \multirow{6}{*}{ Gersteslijpmeelpellets } & $23 a$ & Graanresten \\
\hline & & $23 b$ & Biograanmix \\
\hline & & $23 c$ & Tarwevoergriespellets \\
\hline & & $23 d$ & Gersteslijpmeelpellets \\
\hline & & $23 e$ & Gerstpellen \\
\hline & & $23 f$ & Bacteriefood \\
\hline 24 & Koffiedik & 24 & Koffiedik \\
\hline 25 & Bietenperspulp & 25 & Bietenperspulp \\
\hline 26 & Aardappelstoomschillen & 26 & Aardappelstoomschillen \\
\hline 27 & Stillage & 27 & $\begin{array}{l}\text { Stillage (Maïsfermentatieresten uit } \\
\text { Zeafuelsproces) }\end{array}$ \\
\hline
\end{tabular}

Over de herkomst en/of de productieprocessen waarbij de stof vrijkomt is bij een aantal stoffen geen of onvoldoende informatie verstrekt. In voorkomende gevallen is door middel van bronnenonderzoek bepaald wat de herkomst zou kunnen zijn, gelet op het gebruik van dergelijke stoffen in vergistingsinstallaties in Duitsland, Denemarken of Vlaanderen. Dit betreft dan een aanname.

Op de lijst van LTO/BBO staan drie stoffen die al opgenomen zijn in bijlage Aa van de URMW ${ }^{15}$. Dit zijn maïs (A1.1), silage van hele maïsplanten (A1.1) en beheersgras (B en B1). De code achter deze stoffen verwijst naar de codering van bijlage Aa van de URMW. Voor deze drie stoffen is geen gegevensverzameling uitgevoerd en evenmin heeft een herbeoordeling plaatsgevonden.

${ }^{15}$ Dagtekening 1 juni 2011 


\subsection{Zonnebloemen}

$\mathrm{Er}$ is geen informatie aangeleverd over zonnebloemen. Zonnebloempitten worden op elk werelddeel geteeld $^{16}$. Bulgarije, Frankrijk, Roemenië en Turkije zijn de grootste producten van zonnebloempitten, gevolgd door Spanje en Hongarije (Eurostat database). Deze database geeft nog geen productie op voor de teelt in Nederland. Zonnebloemen kennen een grote diversiteit in gebruiksvormen. De pitten (zaden) worden ingevoerd en verwerkt tot diverse producten. De meeste zonnebloemen worden geteeld voor de olie. De olie wordt vooral in de voedingsmiddelen en genotsindustrie (VGI) toegepast. De kleinere zaden en de bij de verwerking van zonnebloemenpitten (zaad) geproduceerde reststoffen worden vooral als veevoeder (inclusief petfood) afgezet. Deze verwerking kent onderscheidenlijk voorbehandelingen: mechanisch persen van olie of chemisch extraheren van olie (meestal met hexaan dat tijdens het productieproces weer wordt onttrokken aan de olie en hergebruikt) en onderscheid in de mate van ontdoppen van het zaad (volledig ontdoppen, gedeeltelijk ontdoppen of niet ontdoppen, met gradaties daartussen). Hoe lager het aandeel dop, hoe hoger het gehalte aan ruw eiwit is.

Veevoeders worden gemaakt van zonnebloemzaadschilfers en zonnebloemzaadschroot. Bij veevoeding worden deze stoffen ingedeeld op basis van hun ruwe celstofgehalte (RC). Bij biogasproductie wordt in Duitsland wel gebruik gemaakt van silage van zonnebloemen. Met silage van zonnebloemen wordt in Nederland proefsgewijs ervaring opgedaan; het betreft nog geen algemeen ingevoerde praktijk. Bij veevoeding (geiten) vinden ingekuilde zonnebloemen een toepassing (althans dat wordt onderzocht). De biogasopbrengst van zonnebloemen (volledige gewas) is (aanzienlijk) lager dan dat van ingekuilde maïs (Wijnholds, 2008).

Silage van zonnebloemen, zonnebloemmeel en -schroot hebben door het ruweiwitgehalte en de gehalten aan ruwe celstof en eventuele resten olie een potentie als covergistingsmateriaal.

Informatie over de kwaliteit van zonnebloemsilage en de mate van belasting met zware metalen en organische microverontreinigingen is niet ontsloten. Informatie over de samenstelling van zonnebloempitten en van zonnebloemschroot is door bronnenonderzoek getraceerd. De gegevensverzameling is onvolledig. Geëxtraheerd zonnebloemmeel is een vorm van zonnebloemschroot.

Er zijn CBS-gegevens voorhanden van de arealen met productie van zonnebloemen in Nederland: in 2010 bedroeg het areaal 308 ha. Dit betreft ook (en in hoofdzaak) de teelt van buitenbloemen. In 2005 werd 60 kton zonnebloemenschroot geïmporteerd (Bondt et al., 2009). PDV geeft aan dat in de periode van 1 juli 2008 t/m 30 juni 2009261 kton zonnebloemschroot en zonnebloemschilfers door de handel als buitenlandse grondstof werd ingevoerd. Rechtstreeks werd 233 kton ingevoerd waardoor totaal 494 kton diervoedergrondstof beschikbaar was. Hoeveel daarvan uiteindelijk bestemd wordt voor covergistingsmateriaal, is niet bekend.

\section{Zware metalen en arseen}

Zonnebloemzaad doorstaat de milieutoets voor zware metalen; voor arseen is geen gegeven getraceerd. Zonnebloemenschroot doorstaat de milieutoets voor $\mathrm{Cd}, \mathrm{Cu}, \mathrm{Hg}, \mathrm{Pb}$ en $\mathrm{Zn}$. Voor $\mathrm{Cr}, \mathrm{Ni}$ en As zijn geen gegevens getraceerd.

\section{Organische microverontreinigingen van de Meststoffenwet (OM)}

Voor zonnebloemzaad zijn enige gegevens voor gehalten aan $\mathrm{HCH}^{\prime}$ s en $\mathrm{HCB}$ gevonden. Meetwaarden voor $\mathrm{Y}-\mathrm{HCH}$ (lindaan) variëren van 0,023-0,064 mg/kg (Singh et al., 1998; Uhnak et al., 1983). Op basis van deze - gedateerde - meetgegevens doorstaat zonnebloempitten(zaad) niet de milieutoets. Gegevens over andere OM zijn niet getraceerd.

Gehalten aan hexaan in schroot van geëxtraheerde zonnebloempitten zijn niet getraceerd.

\footnotetext{
${ }^{16}$ Voor 2011 wordt wereldwijd een areaal van 24,3 miljoen ha met een totale opbrengst van 32,1 miljoen ton als raming gegeven (http://www.sunflowernsa.com/stats/world-supply/).
} 


\section{Residuen van gewasbeschermingsmiddelen en biociden (OOM)}

Er zijn geen analyseresultaten van GBM's in zonnebloempitten bekend. Ook is niet duidelijke welke van de tien werkzame stoffen gebruikt worden voor de teelt van zonnebloemen (in het buitenland).

\section{Oordeel}

De gegevensverzameling is incompleet. Niet duidelijk is van welke productieprocessen 'zonnebloemen' afkomstig zijn. Dat belemmert de beoordeling van risico's verbonden aan het gebruik van deze stof als covergistingsmateriaal. De stof doorstaat niet de milieutoets voor lindaan op basis van meetwaarden. Zonnebloemen worden wereldwijd geteeld. Het risico van contaminatie van zonnebloemen door lindaan is daardoor niet volledig uit te sluiten. In dit geval kan er namelijk niet van uit gegaan worden dat er geen risico van de aanwezigheid van residuen is, hoewel lindaan uitgefaseerd is in EU27 en enkele andere werelddelen (USA, Canada). Landen met de grootste arealen zonnebloemen liggen buiten de EU-27 (FAO, Statistical yearbook $2010^{17}$ ). Ook ontbreken essentiële gegevens over enkele zware metalen en arseen en over de belasting met residuen van OOM. Op basis van deze stand van zaken kan geen advies ten gunste van opname van zonnebloemen in bijlage Aa worden afgegeven.

\subsection{Bermgras}

Er is geen informatie aangeleverd over bermgras. Gegevens zijn verzameld uit wetenschappelijke rapporten (Spijker et al., 2004, Ehlert et al., 2010).

Bermgras is een algemeen gehanteerd begrip voor het maaisel van wegbermen. Het hangt af van de vorm van het wegbeheer, de bodemgesteldheid en de bodemvruchtbaarheid of gras dominant aanwezig is. Het ingezette verschralingsbeheer ter bevordering van de ontwikkeling van meer ecologische bermvegetaties heeft het aandeel gras verlaagd. Kruiden en leguminosen komen dan vaker voor dan grassen. De begripsomschrijving bermmaaisel is passender voor het maaisel van bermen.

Bermmaaisel lijkt sterk op gras van beheersgrasland en van natuurgebieden. De herkomst is doorgaans nog wel te traceren via de wegbeheerder of besteknemer. Ook de wijze waarop bermmaaisel verkregen wordt, is goed te duiden.

Bermmaaisel kan verontreinigd worden door zwerfvuil en door grond (molshopen), waardoor stoffen aanwezig zijn die het maaisel niet of minder geschikt maken voor vergisting. Indien zwerfvuil vermeden wordt en grond zo min mogelijk verzameld wordt bij het klepelen, dan is er een perspectief voor toepassing als covergistingsmateriaal, met name door de aanwezigheid van ruwe celstof. Bij een goed geleid vergistingsproces zal het digestaat een landbouwkundige waarde hebben zonder ongewenste nevenwerkingen. Bermmaaisel heeft een risico van verontreiniging. Deze verontreiniging kan worden veroorzaakt door het wegverkeer via verbrandingsgassen van brandstoffen en weggebruik (PAK's, minerale olie), slijtage van autobanden (Ni). Ook het wegmeubilair kan verontreiniging veroorzaken $(\mathrm{Zn})$ en tenslotte kan de wegconstructie bijdragen aan verontreinigingen. Aan het maaisel van wegbermen worden verschillende gebruiksfuncties gegeven, zoals veevoer, organisch bodemverbeterend middel en grondstof voor compost. Veel maaisel wordt in Nederland tot groencompost verwerkt. Er zijn diverse publicaties te vinden met informatie over de samenstelling van bermmaaisel. Gegevens van voor 1990 zijn niet meegenomen in verband met wijzigingen in de samenstelling van benzine $(\mathrm{Pb})$ en wijzigingen in de samenstelling van de vegetatie van wegbermen: een ecologisch beheer wordt meer en meer nagestreefd ${ }^{18}$. Er is afdoende informatie beschikbaar over de waardegevende bestanddelen en de gehalten aan zware metalen en arseen, er is beperkte informatie beschikbaar over de gehalten aan organische contaminanten van de Meststoffenwet (OM). Informatie over residuen van OOM is niet beschikbaar.

De Vries et al. (2008) ramen het areaal wegberm in Nederland op 60.000 ha waarvan jaarlijks zo'n 225 kton bermmaaisel vrijkomt bij noodzakelijk wegbermbeheer.

\footnotetext{
${ }^{17}$ http://www.fao.org/economic/ess/ess-publications/ess-yearbook/ess-yearbook2010/yearbook2010-production/jp/

${ }^{18}$ De getrimde bermen van de jaren zeventig en tachtig ter bevordering van het bermtoerisme zijn historie.
} 


\section{Zware metalen en arseen}

Het onderzoek van Spijker et al. (2004) wijst uit dat de samenstelling van het bermmaaisel sterk kan verschillen qua gehalten aan zware metalen en arseen. In acht landelijke regio's werden negen wegbermen bemonsterd en geanalyseerd op deze contaminanten en waardegevende bestanddelen. De milieutoets voor de zware metalen wijst uit dat er overschrijdingen zijn van de maximaal toegelaten vracht aan zware metalen en arseen. Gemiddeld genomen doorstaan bermmaaisels van twee van de regio's de milieutoets en de overige zes hebben één of meerdere contaminanten die normoverschrijdend zijn. Dit verschilt per maaisel. Tabel 3 geeft de uitslag van de milieutoets als percentage van de maximaal toegestane vracht en klasseert de mate van overschrijding in klasses $\leq 100 \%, 100-110 \%, 110-120 \%, 120-130 \%, 130-150 \%, 150-200 \%, 200-300 \%$ en $\geq 300 \%$. Voor Cu en $\mathrm{Zn}$ zijn de percentages gegeven ten opzichte van de verhouding van deze contaminanten in dierlijke mest en gerelateerd aan fosfaat (stap 2 van de milieutoets van het Protocol). Voor overige contaminanten zijn de percentages geclassificeerd voor het mengsel met dierlijke mest bij 50\% menging (stap 3 van de milieutoets van het Protocol). Bermmaaisels van Dinkelland, Eibergen en Hof van Twente zijn in het algemeen schoon en onverdacht; er zijn enkele maaisels die de normen voor zware metalen (As, Cd, Ni, Zn) licht overschrijden. Bermmaaisels van andere regio's tonen vaker en forsere overschrijdingen. De contaminanten die normoverschrijding veroorzaken, verschillen per regio.

\section{Organische microverontreinigingen van de Meststoffenwet (OM)}

Er wordt informatie over organische microverontreinigingen in bermmaaisel in de literatuur gegeven. Veelal betreft dit internationale - peer reviewed - publicaties die geen betrekking hebben op de verontreiniging van bermmaaisel van Nederlandse herkomst. Ehlert et al. (2010) geven data voor drie Groningse provinciale wegen voor zogenoemd overig maaisel. Dit is maaisel exclusief de eerste meter. Deze eerste meter wordt het meest beïnvloed door de wegconstructie en het wegverkeer en heeft daardoor een groter risico om verontreinigd te worden en werd om deze overweging uitgesloten. Zowel voorjaars- als najaarsmaaisel werd geanalyseerd op OM. Het gehalte aan dioxine overschreed de norm voor één van de zeven monsters (143\%, eerste stap milieutoets). Bij dit monster was OCDD verantwoordelijk voor de overschrijding van de norm. OCDD is een congeneer die in natuurlijke omgevingen vaker wordt aangetroffen. Omdat bermmaaisel niet $\mathrm{GMP}^{+}$-gecertificeerd is, wordt de $2^{\mathrm{e}}$ stap van de milieutoets niet uitgevoerd. Die $2^{\mathrm{e}}$ stap zou dit monster echter wel doorstaan.

\section{Residuen van gewasbeschermingsmiddelen en biociden (OOM)}

Het oordeel is gebaseerd op de veronderstelling dat gewasbeschermingsmiddelen en biociden hooguit incidenteel toegepast kunnen worden maar dat dit niet de regel is. Ecologisch bermbeheer verbiedt het gebruik. Onkruidbestrijding kan plaatsvinden. Er zijn geen gehalten van bv. glyfosaat beschikbaar.

\section{Tabel 3.}

Aantal monsters met hun percentuele overschrijdingen van de maximaal toegestane vracht aan zware metalen en arseen voor acht regio's op basis van beschikbare analysegegevens. Per regio werden negen monsters bermmaaisel geanalyseerd (Spijker et al., 2004).

\begin{tabular}{|c|c|c|c|c|c|c|c|c|c|c|}
\hline \multirow[t]{2}{*}{ Regio } & \multirow[t]{2}{*}{ ZM } & \multicolumn{9}{|c|}{ Klasse } \\
\hline & & $\leq 100$ & $\begin{array}{r}100- \\
110\end{array}$ & $\begin{array}{r}110- \\
120\end{array}$ & $\begin{array}{r}120- \\
130\end{array}$ & $\begin{array}{r}130- \\
150\end{array}$ & $\begin{array}{r}150- \\
200\end{array}$ & $\begin{array}{r}200- \\
300\end{array}$ & $>300$ & $\begin{array}{l}\text { To- } \\
\text { taal }\end{array}$ \\
\hline \multirow[t]{8}{*}{ Apeldoorn } & As & 4 & 1 & 3 & 1 & & & & & 9 \\
\hline & $\mathrm{Cd}$ & 7 & & 1 & 1 & & & & & 9 \\
\hline & $\mathrm{Cr}$ & 9 & & & & & & & & 9 \\
\hline & $\mathrm{Cu} / \mathrm{P}_{2} \mathrm{O}_{5}$ & 9 & & & & & & & & 9 \\
\hline & $\mathrm{Hg}$ & 9 & & & & & & & & 9 \\
\hline & $\mathrm{Ni}$ & 8 & 1 & & & & & & & 9 \\
\hline & $\mathrm{Pb}$ & 9 & & & & & & & & 9 \\
\hline & $\mathrm{Zn} / \mathrm{P}_{2} \mathrm{O}_{5}$ & & 1 & & 3 & 2 & 3 & & & 9 \\
\hline \multirow[t]{5}{*}{ Borculo } & As & 3 & 1 & & & 1 & 3 & 1 & & 9 \\
\hline & $\mathrm{Cd}$ & 1 & 1 & & 3 & 1 & 3 & & & 9 \\
\hline & $\mathrm{Cr}$ & 7 & 1 & & 1 & & & & & 9 \\
\hline & $\mathrm{Cu} / \mathrm{P}_{2} \mathrm{O}_{5}$ & 9 & & & & & & & & 9 \\
\hline & $\mathrm{Hg}$ & 9 & & & & & & & & 9 \\
\hline
\end{tabular}




\begin{tabular}{|c|c|c|c|c|c|c|c|c|c|c|}
\hline \multirow[t]{2}{*}{ Regio } & \multirow[t]{2}{*}{$\mathbf{Z M}$} & \multicolumn{9}{|c|}{ Klasse } \\
\hline & & $\leq 100$ & $\begin{array}{r}100- \\
110\end{array}$ & $\begin{array}{r}110- \\
120\end{array}$ & $\begin{array}{r}120- \\
130\end{array}$ & $\begin{array}{r}130- \\
150\end{array}$ & $\begin{array}{r}150- \\
200\end{array}$ & $\begin{array}{l}200- \\
300\end{array}$ & $>300$ & $\begin{array}{l}\text { To- } \\
\text { taal }\end{array}$ \\
\hline \multirow{11}{*}{ Dinkelland } & $\mathrm{Ni}$ & 5 & & & 2 & & 2 & & & 9 \\
\hline & $\mathrm{Pb}$ & 8 & & 1 & & & & & & 9 \\
\hline & $\mathrm{Zn} / \mathrm{P}_{2} \mathrm{O}_{5}$ & 4 & & & & 4 & 1 & & & 9 \\
\hline & As & 9 & & & & & & & & 9 \\
\hline & $\mathrm{Cd}$ & 9 & & & & & & & & 9 \\
\hline & $\mathrm{Cr}$ & 9 & & & & & & & & 9 \\
\hline & $\mathrm{Cu} / \mathrm{P}_{2} \mathrm{O}_{5}$ & 9 & & & & & & & & 9 \\
\hline & $\mathrm{Hg}$ & 9 & & & & & & & & 9 \\
\hline & $\mathrm{Ni}$ & 9 & & & & & & & & 9 \\
\hline & $\mathrm{Pb}$ & 9 & & & & & & & & 9 \\
\hline & $\mathrm{Zn} / \mathrm{P}_{2} \mathrm{O}_{5}$ & 3 & 4 & 1 & 1 & & & & & 9 \\
\hline \multirow[t]{8}{*}{ Eibergen } & As & 9 & & & & & & & & 9 \\
\hline & $\mathrm{Cd}$ & 8 & 1 & & & & & & & 9 \\
\hline & $\mathrm{Cr}$ & 9 & & & & & & & & 9 \\
\hline & $\mathrm{Cu} / \mathrm{P}_{2} \mathrm{O}_{5}$ & 9 & & & & & & & & 9 \\
\hline & $\mathrm{Hg}$ & 9 & & & & & & & & 9 \\
\hline & $\mathrm{Ni}$ & 8 & & 1 & & & & & & 9 \\
\hline & $\mathrm{Pb}$ & 9 & & & & & & & & 9 \\
\hline & $\mathrm{Zn} / \mathrm{P}_{2} \mathrm{O}_{5}$ & 9 & & & & & & & & 9 \\
\hline \multirow{8}{*}{$\begin{array}{l}\text { Hof van } \\
\text { Twente }\end{array}$} & As & 9 & & & & & & & & 9 \\
\hline & $\mathrm{Cd}$ & 6 & 2 & 1 & & & & & & 9 \\
\hline & $\mathrm{Cr}$ & 9 & & & & & & & & 9 \\
\hline & $\mathrm{Cu} / \mathrm{P}_{2} \mathrm{O}_{5}$ & 9 & & & & & & & & 9 \\
\hline & $\mathrm{Hg}$ & 9 & & & & & & & & 9 \\
\hline & $\mathrm{Ni}$ & 9 & & & & & & & & 9 \\
\hline & $\mathrm{Pb}$ & 9 & & & & & & & & 9 \\
\hline & $\mathrm{Zn} / \mathrm{P}_{2} \mathrm{O}_{5}$ & 6 & 3 & & & & & & & 9 \\
\hline \multirow{8}{*}{$\begin{array}{l}\text { Noord- } \\
\text { Brabant }\end{array}$} & As & 8 & & & & 1 & & & & 9 \\
\hline & $\mathrm{Cd}$ & & 1 & & & 5 & 3 & & & 9 \\
\hline & $\mathrm{Cr}$ & 9 & & & & & & & & 9 \\
\hline & $\mathrm{Cu} / \mathrm{P}_{2} \mathrm{O}_{5}$ & 8 & & & & & 1 & & & 9 \\
\hline & $\mathrm{Hg}$ & 9 & & & & & & & & 9 \\
\hline & $\mathrm{Ni}$ & 6 & 1 & 2 & & & & & & 9 \\
\hline & $\mathrm{Pb}$ & 4 & 1 & 1 & & & 2 & 1 & & 9 \\
\hline & $\mathrm{Zn} / \mathrm{P}_{2} \mathrm{O}_{5}$ & & 1 & 4 & 1 & 3 & & & & 9 \\
\hline \multirow[t]{8}{*}{ Overijssel } & As & 9 & & & & & & & & 9 \\
\hline & $\mathrm{Cd}$ & 2 & & 1 & 1 & 4 & 1 & & & 9 \\
\hline & $\mathrm{Cr}$ & 9 & & & & & & & & 9 \\
\hline & $\mathrm{Cu} / \mathrm{P}_{2} \mathrm{O}_{5}$ & 9 & & & & & & & & 9 \\
\hline & $\mathrm{Hg}$ & 9 & & & & & & & & 9 \\
\hline & $\mathrm{Ni}$ & 9 & & & & & & & & 9 \\
\hline & $\mathrm{Pb}$ & 8 & & & & 1 & & & & 9 \\
\hline & $\mathrm{Zn} / \mathrm{P}_{2} \mathrm{O}_{5}$ & & & 1 & 2 & 3 & 2 & 1 & & 9 \\
\hline \multirow{8}{*}{$\begin{array}{l}\text { Regge \& } \\
\text { Dinkel }\end{array}$} & As & & & & 1 & & 1 & 6 & 1 & 9 \\
\hline & $\mathrm{Cd}$ & & & 2 & 1 & & 5 & 1 & & 9 \\
\hline & $\mathrm{Cr}$ & 9 & & & & & & & & 9 \\
\hline & $\mathrm{Cu} / \mathrm{P}_{2} \mathrm{O}_{5}$ & 8 & & & & & 1 & & & 9 \\
\hline & $\mathrm{Hg}$ & 9 & & & & & & & & 9 \\
\hline & $\mathrm{Ni}$ & 1 & 3 & 1 & 2 & 1 & 1 & & & 9 \\
\hline & $\mathrm{Pb}$ & 8 & & & 1 & & & & & 9 \\
\hline & $\mathrm{Zn} / \mathrm{P}_{2} \mathrm{O}_{5}$ & 1 & & & 1 & 2 & & 3 & 2 & 9 \\
\hline Totaal & & 438 & 23 & 20 & 22 & 28 & 29 & 13 & 3 & 576 \\
\hline
\end{tabular}




\section{Oordeel}

Niet alle bermmaaisels zullen voldoen aan de geldende normen voor de maximaal toelaatbare vracht aan contaminanten. Er zijn diverse factoren (wegintensiteit, wegconstructie, bodem en vegetatie) die kunnen bijdragen aan contaminatie. Er zijn regio's waarvan het bermmaaisel afdoende schoon en overdacht is, maar er zijn andere regio's waar dat niet het geval is. Dit belemmert een generieke regeling waarvoor bijlage Aa van de URMW bedoeld is. Op basis van deze stand van zaken kan geen advies ten gunste van opname in bijlage Aa worden afgegeven.

\subsection{Hooi}

Over hooi is geen dossier aangeleverd. Wel zijn vier gehalten aan zware metalen doorgegeven.

Hooi is gemaaid en op het land gedroogd gras of enig ander voedergewas. Hooi is een ruwvoeder. In deze studie wordt hooi van gras in beschouwing genomen. Het groeistadium waarin het gras gemaaid wordt, bepaalt de kwaliteit (weidehooi). Voor meer productieve dieren wordt gras in een jonger stadium gemaaid. Om vervetting bij dieren (bv. paarden) te voorkomen wordt het gras in een meer volgroeid stadium geoogst. Hooi ondergaat een langere droogperiode dan voordrooggras ${ }^{19}$ Ook bij de productie van graszaad wordt (gras)hooi geproduceerd. In 2009 werd in Nederland 218 kton drogestof $^{20}$ geproduceerd. Dit betreft $5 \%$ van het gemaaide oppervlak grasland. Bij hooi wordt onderscheid aangebracht naar schuurhooi ${ }^{21}$, ventilatiehooi ${ }^{22}$, opper ${ }^{23}$ - en baalhooi (Remmelink et al., 2010). Hooi kan door schimmels en stof ongeschikt worden voor vervoedering aan vee.

De kwaliteit van het hooi wordt, naast het groeistadium van het gras waarin het gemaaid wordt bepaald door de botanische samenstelling van het grasland, de bodem, de bodemvruchtbaarheid, de waterhuishouding en antropogene invloeden. Hooi dient, alvorens het de vergister in gaat, een bewerkingstap te ondergaan waardoor de vezels worden verkleind ter voorkoming dat in een vergistingsinstallatie de roerarmen vastlopen/dichtslibben. De ruwe celstof geeft hooi het perspectief van een covergistingsmateriaal.

\section{Zware metalen en arseen}

Door Fouragehandel HISFA zijn vier gehalten aan zware metalen verstrekt ( $\mathrm{As}, \mathrm{Cd}, \mathrm{Hg}$ en $\mathrm{Pb}$ ). Bronnenonderzoek heeft aanvullende meetgegevens over zware metalen gegeven. De milieutoets voor zware metalen en arseen wordt niet doorstaan. Hooi blijkt teveel nikkel te bevatten (overschrijding van de norm met 142\%). Het resultaat is gebaseerd op een gemiddeld gegeven door datamontage. Het aantal bronnen over gehalten aan nikkel is gering (Shober et al., 2007; Umweltbundesamt, 2004). Op basis van de gegevens van Shober et al. (2007) voor hooi uit een boomgaard wordt de milieutoets niet doorstaan, op basis van de gegevens van het Umweltbundesamt (2004) doorstaat hooi wel de milieutoets voor nikkel.

\section{Organische microverontreinigingen van de Meststoffenwet (OM)}

Informatie over OM is niet getraceerd.

\section{Residuen van gewasbeschermingsmiddelen en biociden (OOM)}

Informatie over gehalten aan residuen aan OOM is niet getraceerd.

\section{Oordeel}

Op basis van de gegevensverzameling kan feitelijk geen afdoende weging van het milieurisico worden uitgevoerd. Kuilgras en gras van beheersgrasland zijn opgenomen in bijlage Aa van de URMW. Kuilgras en gras van beheersgrasland doorstaan de milieutoets voor zware metalen (gebaseerd op

\footnotetext{
${ }^{19}$ Voordrooggras wordt bij 35-40\% vochtgehalten rechtstreeks gekuild of in plastic gebaald

${ }^{20}$ De productie van graskuil was toen 5.114 kton drogestof (CBS, 12-11-2010).

${ }^{21}$ Op het veld gedroogd hooi, los in de schuur opgeslagen.

${ }^{22}$ Hooi dat door ventilatie met (verwarmde) lucht wordt gedroogd.

${ }^{23}$ Drogen van hooi door oppers: in hopen opgetast hooi, wordt vooral onder vochtige omstandigheden uitgevoerd.
} 
fosfaat). Bij kuilgras en gras van beheersgrasland ontbreken eveneens gegevens over gehalten aan OM. Bij kuilgras, gras en hooi is er geen reden om te veronderstellen dat gehalten aan OM aanwezig kunnen zijn in zorgvragende gehalten. Gehalten aan residuen van OOM werden bij kuilgras en gras destijds nog niet bij de beoordeling betrokken. Residuen van OOM worden vanaf 1-1-2008 betrokken bij de beoordeling. Het milieurisico verbonden aan hooi dat geschikt is voor vervoedering (schimmelaantasting en stof daargelaten) zou bij hooi niet groter moeten zijn dan die verbonden aan het gebruik van kuilgras. Gelet op de opname van kuilgras en gras van beheersgrasland zou hooi qua zware metalen en arseen geen zwaardere belasting mogen hebben en daarom opgenomen kunnen worden in bijlage Aa van de URMW.

\subsection{Stro van koolzaad}

Over stro van koolzaad werd geen dossier aangeleverd.

Stro van koolzaad resteert na de oogst van het zaad van koolzaad. Het bijproduct vindt afzet als diervoeder (pensprik, structuurverbeteraar en rantsoenverbeteraar) of wordt gebruikt als strooisel in de stal (vervanger van zaagsel, ammoniakbindende stof). $\mathrm{Er}$ is handel in gemalen $(<1 \mathrm{~cm}$ ) en gehakseld koolzaadstro $(3-4 \mathrm{~cm})$. De afzet is beperkt, er wordt gezocht naar perspectiefvolle markten (Janssens et al., 2005). Een raming van de omvang van deze afzet ontbreekt. Bij een opbrengst van 4.4 ton zaad/ha resteert ca. 3,3 ton stro/ha als bijproduct. Het areaal koolzaad in Nederland in 2010 was 2628 ha (CBS StatLine). De raming voor de productie aan koolzaadstro in Nederland is dan 8,7 kton. In EU27 werd in 2010 zo'n $6.10^{6}$ ha koolzaad verbouwd met Duitsland, en Frankrijk als grootste producenten, gevolgd door Polen, Roemenië en Tsjechië (Eurostat database). De productie bedroeg 20.395 kton zaad. Bij deze productie komt ca. 15.296 kton stro vrij. Teeltsaldo voor dit gewas in genoemde lidstaten is gunstiger dan in Nederland (Janssens et al., 2005).

\section{Zware metalen en arseen}

De gegevensverzameling over de gehalten aan zware metalen en arseen is niet compleet. Gegevens ontbreken over $\mathrm{Cr}$, Ni en As. Voor overige zware metalen wordt de milieutoets doorstaan met uitzondering van Cd (248\%). De gegevens van Cd zijn afkomstig van Angelova et al. (2004). Angelova et al. (2004) rapporteerden over contaminatie van landbouwgewassen op verschillende afstanden van Pools metaalverwerkend bedrijf (non ferro). Hoewel gegevens van koolzaadstengels van teelten op gecontamineerde grond uitgesloten werden bij de datamontage, doorstaat koolzaadstro op basis van gegevens van dit gewas van niet-gecontamineerde grond het product de milieutoets voor Cd niet. Het ontbreken van enig verantwoord gegeven voor de situatie in Nederland belemmert hier een verantwoorde toets.

\section{Organische microverontreinigingen van de Meststoffenwet (OM)}

Er zijn geen gegevens getraceerd over gehalten aan OM in koolzaadstro.

\section{Residuen van gewasbeschermingsmiddelen en biociden (OOM)}

Er zijn geen gegevens getraceerd over gehalten aan OOM in koolzaadstro in de literatuur. De systematiek beschreven in bijlage 5 reikt een handvat om een beoordeling van deltamethrin en glyfosaat te kunnen uitvoeren. Deltamethrin doorstaat niet de milieutoets van het protocol, de maximaal toelaatbare vracht wordt met een factor 174,3 overschreden. Wel doorstaat deze actieve stof de milieutoets voor elk van de drie gegeven alternatieven. Glyfosaat doorstaat de milieutoets van het protocol en dus ook die op basis van de gegeven alternatieven.

\section{Oordeel}

Informatie ontbreekt om de milieutoets voor zware metalen en arseen, OM en OOM volledig uit te voeren. In Nederland is het volume koolzaadstro gering in vergelijking met ons buurland Duitsland ${ }^{24}$. Het milieurisico verbonden aan koolzaadstro afkomstig van Nederlandse teelten zal beperkt zijn. Import van koolzaadstro uit EU27 kan dit risico doen toenemen. In welke mate, is niet aan te geven.

\footnotetext{
${ }^{24}$ In Duitsland werd in $20101,47.10^{6}$ ha koolzaad geteeld, in Nederland 2.832 ha.
} 
Koolzaadstro is één van de vormen van stro die in Nederland als covergistingsmateriaal worden aangeboden. In het algemeen bevat stro afkomstig van zaadgewassen lage tot zeer lage gehalten aan nutriënten $(\mathrm{N}, \mathrm{P})$. Zaadgewassen vermijden via verschillende biologische routes en processen opslag van verontreinigende stoffen in het zaad. Die stoffen blijven daardoor eerder achter in het stro, voorzover er geen sprake is van uitloging tijdens afrijping. In combinatie met lage gehalten aan nutriënten doorstaat stro vaker niet de milieutoets. Voor stro van zaadgewassen wordt nader onderzoek naar de mate van belasting aanbevolen; koolzaadstro zou hiervan een onderdeel kunnen zijn.

\subsection{Tarwe}

Een dossier over tarwe werd niet aangeleverd.

Tarwe is een generieke formulering. Onder de begripsomschrijving tarwe kunnen diverse onbewerkte en bewerkte stoffen gerangschikt worden. In deze paragraaf worden onbewerkte stoffen besproken die vrijkomen door de oogst van het gewas. Tarwekorrels zijn als covergistingsmateriaal opgenomen in bijlage Aa van de URMW (A1.1.). Bij de oogst van tarwe resteert tarwestro. Een andere vorm van de teelt van tarwe die betekenis heeft bij de productie van substraten voor vergisting is gehele plant silage (GPS) van tarwe (tarwe-GPS). Het areaal tarwe in 2010 in Nederland was 307.736 ha (CBS StatLine). CBS geeft 26.964 kton stro en kaf op voor de productie in 2010.

Over gehele plant silage (GPS) van wintertarwe dateert het meest recente gegeven uit 2006; het areaal was $358 \mathrm{ha}^{25}$ (CBS StatLine). Dit levert als raming circa 5,7 kton GPS drogestof of 14,3 kton GPS als product op.

\section{Zware metalen en arseen}

De gegevensverzameling berust op een ingrijpende vorm van datamontage. Deels zijn gehalten teruggerekend uit assen die resteren na verbranding van stro. Bij stro zijn meetwaarden voor $\mathrm{Cd}$ beschikbaar. Er is een parallel getrokken tussen stro en GPS.

Gegevensverzameling over deze anorganische contaminanten is onvolledig; meetgegevens over kwik en arseen ontbreken of zijn afkomstig van assen van stro. Er is geen reden om aan te nemen dat deze contaminanten in zorgvragende gehalten aanwezig zullen zijn in stro of GPS van Nederlandse teelten. Overige zware metalen doorstaan de milieutoets op basis van gemiddelde waarden.

\section{Organische microverontreinigingen van de Meststoffenwet (OM)}

Er zijn geen gegevens getraceerd over gehalten aan OM in tarwestro en -GPS.

\section{Residuen van gewasbeschermingsmiddelen en biociden (OOM)}

Voor stro en GPS zijn geen meetwaarden gevonden voor OOM. Gegevens zijn afkomstig van bewerkte vormen van tarwe en door datamontage.

Er zijn dan meetwaarden beschikbaar voor pirimifos-methyl, lambda-cyhalothrin en glyfosaat. Voor andere OOM zijn waarden geraamd (Bijlage 5). Voor metsulfuron-methyl, pirimifos-methyl, deltamethrin, mancozeb, lambda-cyhalothrin, MCPA, glyfosaat, thiofanaat-methyl en esfenvaleraat kan een milieutoets worden uitgevoerd. Glyfosaat doorstaat de milieutoets van het protocol, de overige OOM niet. De factoren voor overschrijding zijn voor metsulfuron-methyl, pirimifos-methyl, deltamethrin, mancozeb, lambda-cyhalothrin, MCPA, thiofanaat-methyl en esfenvaleraat zijn respectievelijk 10.149, 51.174, 8.481, 276, 290, 51, 39 en 30. Metsulfuron-methyl, pirimifos-methyl en deltamethrin doorstaan niet de milieutoets indien alternatieve systematieken 1 of 3 worden toegepast (factoren van overschrijding zijn respectievelijk 27, 35 en 7), metsulfuron-methyl en pirimifos-methyl doorstaan de milieutoets niet bij toepassing van de systematiek van alternatief 2 (factoren van overschrijding zijn respectievelijk, 2,7 en 3,5).

\footnotetext{
${ }^{25}$ Andere vormen van GPS zijn tritical-GPS en zomergerst-GPS met in 2006 arealen van respectievelijk 123 en 131 ha. Triticale is een kruising tussen tarwe en rogge.
} 


\section{Oordeel}

Informatie ontbreekt om de milieutoets voor zware metalen en arseen, OM en OOM volledig uit te voeren. Het volume aan wintertarwe-GPS in Nederland is gering. Daardoor zal het milieurisico verbonden aan het gebruik van GPS van Nederlandse teelten als covergistingsmateriaal beperkt zijn. Bij stro van tarwe zijn er aandachtspunten. Een ingrijpende vorm van datamontage is nodig om tot toetsing op milieubezwaarlijkheid over te gaan. Voor stro van zaadgewassen wordt nader onderzoek naar de mate van belasting aanbevolen; tarwestro zou hiervan een onderdeel kunnen zijn.

\subsection{Erwten}

Er is geen dossier over erwten aangeleverd.

Het zaad van erwten is een toegelaten covergistingsmateriaal (A.1.1 van Bijlage Aa van URMW). Bij de oogst resteren loofresten. Van erwten kan ook gehele plant silage (erwten-GPS) gemaakt worden. In de veevoedingsliteratuur (biologische landbouw) heeft gehele plant silage van gerst met erwt aandacht.

Erwten worden verwerkt tot diverse producten. Bij die verwerking resteren erwtenpersvezels, nadat geweekte en fijngemalen erwten ontdaan zijn van erwtenzetmeel. Dit erwtenzetmeel wordt verder verwerkt door de levensmiddelenindustrie. Deze reststroom is nog relatief rijk aan eiwit (lysine) en kan verder bewerkt worden door het erwteneiwit af te scheiden. Erwteneiwit vindt afzet in de veevoederindustrie. Erwteneiwit en erwtenvezels kunnen weer gemengd worden tot een erwtencrème die afzet vindt als veevoeder.

Erwten worden ook geconserveerd of diepgevroren door de levensmiddelenindustrie. Het areaal peulvruchten in 2010 was ca. 3200 ha $^{26}$ waarvan enkele honderden ha groene erwt (ca. 500 ha). Er is geen gegeven beschikbaar van het areaal erwten-GPS. Raming van de productie aan erwten is 22 kton in 2010 .

\section{Zware metalen en arseen}

De verzameling van gegevens is onvolledig.

Bij gehele plant silage van erwt ontbreken gegevens over $\mathrm{Cr}$, $\mathrm{Ni}$ en $\mathrm{Pb}$. Overige zware metalen en arseen doorstaan de milieutoets.

Bij de bewerkte producten van erwten is datamontage toegepast door gehalten van zware metalen en arseen van erwt gelijk te stellen aan die in de bewerkte producten. De vooronderstelling is dat bewerking geen effect heeft op de gehalten aan deze anorganische contaminanten. Erwtenvezels, erwtenpersvezels, erwteneiwit en erwtencrème doorstaan dan de milieutoets. Hierop vormen erwtenvezels en erwtenpersvezels een uitzondering: Zn doorstaat niet de milieutoets (overschrijding respectievelijk $139 \%$ en $347 \%$ ).

\section{Organische microverontreinigingen van de Meststoffenwet (OM)}

Er zijn geen gegevens beschikbaar over PCB's, PAK's en minerale olie. Er is geen verwachting dat deze stoffen in zorgvragende gehalten aanwezig zijn. Overige organische verontreinigingen doorstaan de milieutoets met uitzondering van lindaan.

\section{Residuen van gewasbeschermingsmiddelen en biociden (OOM)}

Vier actieve stoffen zijn beoordeeld voor het gehele gewas, namelijk deltamethrin, lambdacyhalothrin, glyfosaat en esfenvaleraat. Deltamethrin, lambda-cyhalothrin en esfenvaleraat leiden tot een overschrijding van de vracht met respectievelijk een factor 1.234, 845 en 17 bij toepassing van de systematiek van het protocol en respectievelijk met een factor 1,1 en 1,7 bij toepassing van alternatieven 1 en 3 voor deltamethrin en lambda-cyhalothrin. Dit is gebaseerd op toepassing van MRLwaarden.

\footnotetext{
${ }^{26}$ Land- en tuinbouwcijfers, LEI, 2010.
} 


\section{Oordeel}

\section{Erwten-GPS}

Informatie ontbreekt om de milieutoets voor zware metalen en arseen, OM en OOM volledig uit te voeren. Erwten-GPS doorstaat de milieutoets, bij $\mathrm{Cr}$, Pb en Ni ontbreken meetgegevens. Bij erwtenGPS is er geen reden om aan te nemen dat $\mathrm{Cr}$ en $\mathrm{Pb}$ in zorgvragende gehalten aanwezig zijn. Voor $\mathrm{Ni}$ is dit niet duidelijk. Het volume aan erwten-GPS in Nederland is gering. Het milieurisico verbonden aan het gebruik van GPS van Nederlandse teelten als covergistingsmateriaal zal beperkt zijn. Er is een aandachtspunt bij de gehalten aan OOM (deltamethrin en lambda-cyhalothrin). Ook op basis van alternatieven voor de systematiek van de milieutoets voor OOM wordt een overschrijding van de toelaatbare vracht geconstateerd.

\section{Verwerkingsproducten van erwten}

Bij producten van de verwerking van erwten ontbreekt een inzicht in de productieprocessen en de daarbij gebruikte grond- en hulpstoffen. Informatie over de belasting met verontreinigingen ontbreekt. Door een vergaande vorm van datamontage door te voeren onder de veronderstelling dat de mate van belasting van de producten van verwerking gelijk is aan die van de grondstof erwt, wordt de milieutoets doorstaan m.u.v. voor die voor $\mathrm{Zn}$ voor erwtenvezel en erwtenpersvezel. Dit wordt veroorzaakt door het lagere gehalte aan stikstof in deze verwerkte erwtproducten. Informatie over OM en OOM ontbreekt. $\mathrm{Er}$ is daardoor een milieurisico. Omdat het volume aan erwten-producten in Nederland beperkt is, zal dit milieurisico verbonden aan het gebruik van GPS van Nederlandse teelten als covergistingsmateriaal beperkt zijn.

Geadviseerd wordt om de productieprocessen van de verwerking van erwt nader te besturen en op basis daarvan erwtproducten te selecteren voor nader chemisch onderzoek op waardegevende bestanddelen en anorganische en organische contaminanten.

\subsection{Maïs}

Korrelmaïs is opgenomen in bijlage Aa van de URMW (IV.A1.1).

\subsection{Maïssilage}

Maïssilage is opgenomen in bijlage Aa van de URMW (IV.A1.1).

\subsection{Beheersgras}

Beheersgras is opgenomen in bijlage Aa van de URMW (IV.A1.1).

\section{$4.11 \quad$ Bakkerijrestproducten}

Er is geen informatie aangeleverd over bakkerijrestproducten/koekmix.

Bakkerijrestproducten variëren in samenstelling en aandeel van de reststromen. De reststromen komen vrij bij de productieprocessen van brood en koek, broodresten, broodproducten, brood- en deegresten. Bakkerijrestproducten komen ook vrij door retour uit winkels en supermarkten. Dergelijke retourproducten kunnen opgevat worden als een levensmiddel waarvan de THT is verstreken. 
Producten waarvan de THT is verstreken zijn als afval- of reststof al opgenomen in bijlage Aa van de URMW $^{27}$. Bakkerijrestproducten hebben door hun verschillende herkomst en samenstelling een verschillende aard en samenstelling. Visueel zullen de verschillende afval- en reststromen verschillend zijn. Een deel van deze reststromen wordt gebruikt als veevoeder.

Bakkerijrestproducten bestaan in hoofdzaak uit koolhydraten, ruwe celstof, vetten en/of suikers waardoor een bijdrage aan de biogasproductie geleverd kan worden. Bij een goed geleid vergistingsproces zal het digestaat van vergisting van bakkerijrestproducten geen ongewenste nevenwerkingen hebben.

Over de samenstelling van bakkerijrestproducten is echter weinig adequate informatie beschikbaar. Ook het volume van de betrokken hoeveelheid is onbekend. Bakkerijrestproducten hebben diverse gebruiksvormen. Bouwmeester et al. (2006) ramen dat het volume van gemengde stromen op circa 100 kton; bakkerijrestproducten zijn hiervan een onderdeel. Oosterhout en Laarhoven (2003) geven voor 2001 een raming van 150 kton. Het totale aandeel van reststromen uit de voedingsmiddelen en genotsindustrie (VGI) wordt door Bondt en Meeusen (2008) geraamd op 7,5 miljoen ton. Naar huidige beeldvorming betreft het een gering volume van dit totale volume.

\section{Zware metalen en arseen}

Tabel 4 geeft de informatie die uit gegevensformulieren werd verkregen. De informatie betreft het resultaat van de milieutoets op zware metalen. Er is één volledige analyse op zware metalen en arseen beschikbaar, drie onvolledige en bij één verzoek werd in het geheel geen informatie gegeven. Ook het NEVO-bestand ${ }^{28}$ geeft informatie over gehalten aan stikstof, fosfor, Cu en $\mathrm{Zn}$ in broodproducten en in koekproducten. Dit betreft het levensmiddel. Het NEVO-bestand geeft geen informatie over gehalten in restproducten. Bij brood- en koekproducten doorstaan deze levensmiddelen altijd de milieutoets voor Cu en $\mathrm{Zn}$.

\section{Tabel 4}

Verhouding in procenten van de maximaal toegestane vracht aan $\mathrm{Cd}, \mathrm{Cr}, \mathrm{Hg}, \mathrm{Ni}$, $\mathrm{Pb}$ en $\mathrm{As}$ en de overschrijding van de verhouding van $\mathrm{Cu} / \mathrm{P}_{2} \mathrm{O}_{5}$ en $\mathrm{Zn} / \mathrm{P}_{2} \mathrm{O}_{5}$ voor bakkerijrestproducten ten opzichte van die van zuiveringsslib van producten die bij het ministerie van LNV-DKI aangemeld werden voor opname in bijlage Aa van de URMW. Getalswaarden hoger dan 100\% wijzen overschrijding uit.

\begin{tabular}{|c|c|c|c|c|c|}
\hline Contaminant & $\begin{array}{c}\text { Bakkerij- } \\
\text { restproducten } \\
\text { (brood- en } \\
\text { deegresten) }\end{array}$ & $\begin{array}{l}\text { Retour brood } \\
\text { bakkerijen }\end{array}$ & $\begin{array}{l}\text { Brood- } \\
\text { producten }\end{array}$ & Deeg & $\begin{array}{l}\text { Brood en } \\
\text { brooddeeg }\end{array}$ \\
\hline $\mathrm{Cd}$ & $* 1$ & 103 & 49 & 103 & $*$ \\
\hline $\mathrm{Cr}$ & $*$ & 55 & $*$ & $*$ & $*$ \\
\hline $\mathrm{Cu} / \mathrm{P}_{2} \mathrm{O}_{5}$ & 5 & 26 & 4 & $*$ & $*$ \\
\hline $\mathrm{Hg}$ & $*$ & 33 & $*$ & 20 & $*$ \\
\hline $\mathrm{Ni}$ & $*$ & 76 & $*$ & $*$ & $*$ \\
\hline $\mathrm{Pb}$ & 15 & 21 & 3 & 10 & $*$ \\
\hline $\mathrm{Zn} / \mathrm{P}_{2} \mathrm{O}_{5}$ & $*$ & 17 & 11 & $*$ & $*$ \\
\hline As & $*$ & 82 & $*$ & 12 & $*$ \\
\hline
\end{tabular}

\footnotetext{
${ }^{27}$ C.2.3. Reststof die als mengsel is vrijgekomen bij het fabrieksmatig uitpakken door een daartoe gespecialiseerd bedrijf van uitsluitend verpakte voedingsmiddelen die afkomstig zijn van detailhandel, groothandel of producenten en uitsluitend wegens overschrijding van de houdbaarheidsdatum, verpakkingsfouten of verkeerde bewaring ongeschikt zijn geworden voor humane consumptie. Het mengsel bestaat uit uitgepakte voedingsmiddelen die oorspronkelijk bestemd waren voor humane consumptie en is vrij van verpakkingsmateriaal en reinigingswater (uitgepakte voedingsmiddelen voor humane consumptie).

${ }^{28}$ http://nevo-online.rivm.nl/
} 


\section{Organische microverontreinigingen van de Meststoffenwet (OM)}

$E r$ is een onvolledige analyse van één monster retour brood van bakkerijen beschikbaar. Die wijst uit dat er geen zorg is - hoe kan het ook anders - voor dioxine, de drin's en de HCH's.

\section{Residuen van gewasbeschermingsmiddelen en biociden (OOM)}

$\mathrm{Er}$ is een overschrijding gevonden van metsulfuron-methyl, pirimifos-methyl, deltamethrin, mancozeb, lambda-cyhalothrin, MCPA, thiofanaat-methyl en esfenvaleraat bij toetsing volgens het protocol (overschrijdingsfactoren van respectievelijk 3.383, 17.058, 2.827, 92, 97, 17, 13 en 10). Toetsing aan de systematieken van alternatief 1 en 3 wijst op overschrijding bij metsulfuron-methyl, pirimifosmethyl en deltamethrin (overschrijdingsfactoren van respectievelijk 9, 12 en 2,4). Verwacht wordt dat de OOM vooral in die gewasdelen voorkomen die niet gebruikt worden voor levensmiddelenproductie.

\section{Oordeel}

Bakkerijrestproducten zijn niet voorzien van veel gegevens. Er moet datamontage uitgevoerd worden om tot een oordeelvorming te komen. Er is geen directe aanwijzing dat zware metalen en arseen een zorgpunt zijn bij deze afval- en reststoffen. Cadmium blijkt tweemaal normoverschrijdend te zijn $(103 \%)$. Aan deze mate van overschrijding wordt geen bijzondere betekenis gehecht. Gehalten aan OM zijn incompleet maar er is geen reden om aan te nemen dat deze contaminanten in zorgvragende gehalten aanwezig zullen zijn, tenzij bakkerijrestproducten afkomstig zijn van fouten in de productie van brood- en koekproducten waardoor deeg en gebak aan te hoge temperaturen werden blootgesteld. Gehalten aan OOM zijn niet bekend, hierop vormen pirimifos-methyl, lambdacyhalothrin, glyfosaat uitzonderingen. Pirimifos-methyl vormt een aandachtspunt, omdat deze actieve stof geen van de toetsingen doorstaat. Bij de andere OOM zijn MRL-waarden toegepast of wordt de milieutoets doorstaan bij opvolgen van het protocol of één van de gegeven alternatieven. In levensmiddelen worden daardoor geen normoverschrijdende gehalten van deze actieve stoffen verwacht, maar dat is anders voor de restproducten van grondstoffen voor levensmiddelenproductie (zie tarwevoergriespellets). In welke mate pirimifos-methyl wordt overgedragen door grondstoffen naar bakkerijrestproducten is niet bekend. Het volume is beperkt waardoor het milieurisico beperkt is. Bakkerijrestproducten die niet aan te hoge temperaturen zijn blootgesteld en bestaan uit resten brood of deeg die geschikt zijn voor menselijke consumptie, maar door de procesvoering overtollig zijn geworden, zijn geschikt om als covergistingsmateriaal te kunnen worden toegepast.

\subsection{Sojasuiker}

Er is geen informatie aangeleverd over sojasuiker.

Sojabonen worden als grondstof onder andere toegepast in de levensmiddelen- en veevoederindustrie, chemische industrie, farmaceutische industrie en dragen bij aan de productie van een groot aantal producten variërend van textiel, voedsel tot antibiotica. Sojasuiker is één van de vele bijproducten van de verwerking van sojabonen. Sojasuiker is één van de benamingen die in de praktijk gebruikt worden voor een product dat ontstaat bij de verwerking van ontvette sojaschilfers. De schilfers worden met een waterig ethanol extract ontdaan van suikers en in water en ethanol oplosbare koolhydraten. Nadat door verdamping de ethanol verwijderd is, wordt water verdampt, wat resteert in een bruine viskeuze siroop. De sojaschilfers zijn weer een bijproduct van de winning van sojaolie uit sojabonen. Aan sojasuiker worden de namen sojaboonvelasse en sojaboonmelasse ${ }^{29}$ gegeven. In de literatuur is soybean vinasse het restproduct van de bioethanolproductie van sojaboonmelasse. Over de verwerking van sojabonen door de sojaolie-industrie is door het Productschap Diervoeder (PDV, 2007) een risicobeoordeling opgesteld ${ }^{30}$. Deze risicobeoordeling hanteert het begrip sojavelasse. In deze

\footnotetext{
${ }^{29}$ Het begrip soybeanmolasses werd geintroduceerd door D. Chajuss van Hayes Asdod Ltd. ter onderscheiding van soybeanwhey en 'condensed soybean solubles' in begin jaren zestig van de vorige eeuw. Sindsdien heeft de verwerking van sojaboon en de bijproducten een grote vlucht genomen waardoor de samenstelling en eigenschappen van de bijproducten gewijzigd is.

${ }^{30}$ Productschap Diervoeder, 2007. Risicobeoordeling sojaolie-industrie, Versie 09-01-2007. Code: $3012^{\mathrm{E}}$. http://www.gmpplus.org/downloads/Risicobeoordeling_Sojaolie-industrie_09-01-2007_EINDVERSIE[1].pdf (link inmiddels verwijderd).
} 
paragraaf wordt hierbij aangesloten en het begrip sojavelasse gebezigd. Sojavelasse kent diverse gebruiksvormen waaronder als grondstof voor de bioethanolproductie en als substraat voor de productie van gist en enzymen.

\section{Sojaboon}

In Nederland was in 2010 de teelt van sojaboon 5 are (!, één bedrijf) groot (CBS StatLine). De in- en uitvoer van sojabonen worden door het CBS gerubriceerd onder de posten sojabonen bestemd voor zaai, sojabonen ook indien gebroken niet bestemd voor zaai en meel van sojabonen. CBS geeft aan dat het een onderschatting betreft (CBS StatLine). Er wordt meer aan zaad en meel uitgevoerd dan ingevoerd. Sojabonen (ook gebroken) worden verwerkt in Nederland wat leidt tot de export van zaad en meel. In 2010 werd 3.468 kton ingevoerd en 1.608 kton uitgevoerd (CBS StatLine). Daardoor is er een indicatie dat 1.859 kton in Nederland werd verwerkt. Bij de verwerking van sojabonen tot sojaolie resteert per eenheid olie vier eenheden bijproducten. Bijproducten bij sojabonenverwerking zijn naast velasse, hullen, vlokken, schroot, 'schlamm', eiwitconcentraat, lecithine en sediment afhankelijk van de bewerkingsstap. Het volume van sojavelasse is niet bekend.

In de EU27 is Italië de grootste producent van sojabonen (134.700 ha). De teelt vindt vooral in de zuidelijke lidstaten plaats. In totaal werd in 2009 op 304.770 ha sojabonen geteeld (FAO, 2011). Het merendeel van de sojabonen wordt door EU27 geïmporteerd.

\section{Zware metalen en arseen}

Informatie over de belasting met zware metalen en arseen is niet compleet. Een vergaande vorm van datamontage werd uitgevoerd door gegevens van velasse, sojazaad en schroot en EG-verordening 2002/32/eg bijeen te brengen. Gegevens blijven ontbreken over Cr, Ni en As. Overige zware metalen doorstaan dan wel de milieutoets.

\section{Organische microverontreinigingen van de Meststoffenwet (OM)}

Informatie over gehalten aan OM is niet getraceerd.

\section{Residuen van gewasbeschermingsmiddelen en biociden (OOM)}

Informatie over belasting met residuen van OOM is niet bekend.

\section{Oordeel}

De gegevensverzameling over 'sojasuiker' of velasse is incompleet. Informatie blijft mankeren over het productieproces of de productieprocessen die worden toegepast bij het product of de producten die in Nederland onder de duiding van 'sojasuiker' worden verhandeld. Een vergaande vorm van datamontage is uitgevoerd maar dat leidt niet tot een afdoend inzicht in de mate van belasting van velasse met contaminanten en vrijwaring van enig milieurisico. Velasse heeft verschillende gebruiksvormen, bijvoorbeeld die als grondstof voor bioethanolproductie. Velasse wordt wereldwijd geproduceerd. Het volume is naar verwachting qua potentieel groot. Het merendeel van de sojabonen die in EU27 worden verwerkt, komt uit andere werelddelen. Meer zicht op de samenstelling en vooral de belasting met verontreinigingen is nodig om tot een verantwoord oordeel te kunnen komen.

\subsection{Uienpulp}

Er werd geen informatie verstrekt. Gegevens werden verzameld van gegevensformulieren van verzoeken voor opname van restproducten van verwerking van uien en uit de literatuur.

Bij de verwerking van uien komen diverse afval- en reststromen vrij. Afval- en reststromen komen onder mee vrij bij de productie van uienolie. Bij dit verwerkingsproces worden uien gehakseld en gekookt waarbij door destillatie vluchtige uienoliën worden verkregen. Het gehakselde materiaal bevat uienpellen. De pulp die resteert is één van de restproducten. Die pulp kan een bewerking ondergaan waarbij ontwaterd wordt. Dit verwerkingsproces resulteert in een dikke fractie, aangeduid met uienpulp en een dunne fractie die met uienwater wordt aangeduid. Een tweede reststroom ontstaat bij de verwerking van zilveruien (inmaak). Nadat de zilveruien gespoeld zijn en ontdaan van grondtarra worden uien gesorteerd. Uitgesorteerde uien worden bestemd voor covergistingsmateriaal. Daarnaast 
wordt het veldgewas uien geschikt gemaakt voor de handel door te schonen en te verpakken. Reststromen ontstaan al bij het lossen. Grondtarra wordt verwijderd en ongeschikte uien (rot, beschadigd) worden eruit gesorteerd (gewastarra). De loofaanzet (staart) wordt verwijderd (afstaarten) en rokken (uienpellen), ondermaatse uien en wortels worden verwijderd. Uienpulp is dus een bepaalde vorm van een uienreststroom; er zijn echter verschillende andere reststromen van de verwerking van uien.

Meeusen et al. (2008) geven de volgende orden van grootte voor de volumina reststromen die ontstaan bij de verwerking van uien:

- Lossen: 4.800 ton tot 5.400 ton;

- Afstaarten: 9.600 ton tot 10.800 ton;

- Sorteren: 2.400 ton tot 2.700 ton.

Koppejan et al. (2009) geven een raming van 60 kton voor sorteerafval. De reststroom van uienolieproductie, uienpulp, wordt door Boersma en Hemmes (2001) voor 2001 geraamd op 11,5 kton; ook zij ramen de reststroom van sorteren op $60 \mathrm{kton} / \mathrm{jaar}$. Bij een gegevensformulier werd de te vergisten hoeveelheid uienpulp geraamd op $10 \mathrm{kton} / \mathrm{jaar}$.

Alle vormen van uienreststromen kunnen meer of minder bijdragen aan de biogasproductie. De bijdrage van uienwater zal weliswaar - aanzienlijk - lager zijn dan die van dierlijke mest maar dit wordt in het kader van deze deskstudie niet als bezwaarlijk aangemerkt (zie hoofdstuk 3, opmerking bij stap 2).

De samenstelling van de uienreststromen anders dan zware metalen en arseen, OM en OOM geeft geen aanleiding om te veronderstellen dat bij verantwoord landbouwkundig gebruik de bodem schade onder vindt.

\section{Zware metalen en arseen}

Afval- en reststromen die vrij komen bij de productie van uienoliën onderschrijden de norm. Ook uitgesorteerde en gespoelde zilveruien doorstaan de milieutoets (Tabel 5). Uienpellen en uienreststromen doorstaan niet altijd de toets. De meetgegevens zijn zeer variabel. Er is een analyse waarbij de gehalten op of rond de detectielimieten schommelen, maar er zijn ook twee analyses beschikbaar die meetbare gehalten geven met een niet verwaarloosbaar niveau. Tabel 5 geeft een resultaat van de milieutoets voor een uienreststroom op basis van meest recente gegevens na afstemming met het belanghebbende handelshuis.

Wat exact de oorzaak is voor het verschil in belasting met zware metalen en arseen, kan niet achterhaald worden. Aannemelijk is dat grondtarra in uienpellen bijdraagt aan de overschrijding van de normen. Grondtarra is echter ongewenst bij vergisting omdat dit leidt tot bezinksel.

\section{Tabel 5}

Verhouding in procenten van de maximaal toegestane vracht aan $\mathrm{Cd}, \mathrm{Cr}, \mathrm{Hg}, \mathrm{Ni}$, $\mathrm{Pb}$ en $\mathrm{As}$ en de overschrijding van de verhouding van $\mathrm{Cu} / \mathrm{P}_{2} \mathrm{O}_{5}$ en $\mathrm{Zn} / \mathrm{P}_{2} \mathrm{O}_{5}$ voor restproducten van de verwerking van uien ten opzichte van die van zuiveringsslib. Getalswaarden hoger dan $100 \%$ wijzen overschrijding uit.

\begin{tabular}{|c|c|c|c|c|c|c|}
\hline Contaminant & Uienpulp & Zilveruien & $\begin{array}{c}\text { Bio energy } \\
\text { onion }\end{array}$ & Uiensap & Uienpulp & $\begin{array}{l}\text { Uienreststromen } \\
\text { (uienpellen) }\end{array}$ \\
\hline $\mathrm{Cd}$ & 53 & 49 & 55 & 42 & 32 & 185 \\
\hline $\mathrm{Cr}$ & 9 & 24 & 29 & 15 & 10 & 75 \\
\hline $\mathrm{Cu} / \mathrm{P} 2 \mathrm{O} 5$ & 3 & 18 & 17 & 10 & 25 & 55 \\
\hline $\mathrm{Ni}$ & 36 & 42 & 43 & 32 & 28 & 130 \\
\hline $\mathrm{Pb}$ & 6 & 11 & 10 & 7 & 6 & 31 \\
\hline $\mathrm{Zn} / \mathrm{P} 2 \mathrm{O} 5$ & 54 & 24 & 19 & 6 & 38 & 709 \\
\hline As & 30 & 33 & 35 & 20 & 14 & 162 \\
\hline
\end{tabular}




\section{Organische microverontreinigingen van de Meststoffenwet (OM)}

Hierover is geen informatie aangetroffen. Bij dit soort afval- en reststromen is er geen reden om de aanwezigheid van zorgvragende gehalten aan te treffen tenzij deze contaminanten via grondtarra worden aangevoerd of de reststromen een verbrandingsproces hebben ondergaan.

\section{Residuen van gewasbeschermingsmiddelen en biociden (ООM)}

Gehalten in één monster uienreststromen (uienpellen) van chloorprofam, metalaxyl, tebuconazool, pendimethalin, carbendazim, fluazinam, thiofanaat-methyl en triadimenol zijn bekend. Dit leidt tot jaarvrachten van $1,5 \mathrm{~g} / \mathrm{ha}$ (fluazinam) tot $65 \mathrm{~g} / \mathrm{ha}$ (tebuconazool). Of deze vrachten aanleiding geven tot zorg, vraagt in beginsel nadere aandacht. Van de 10 actieve stoffen die door het RIVM zijn beoordeeld in bijlage 5, leiden deltamethrin, mancozeb, lambda-cyhalothrin, metam-natrium, thiofanaat-methyl en esfenvaleraat bij toepassing van het protocol tot overschrijding van de jaarvracht (overschrijdingsfactoren van respectievelijk $72,4.694,494,341,6.839$ en 25). Alleen mancozeb geeft een kleine overschrijding bij alternatief 1 en 3 (overschrijdingsfactor 1,5). De vracht aan mancozeb is echter gebaseerd op een MRL, waardoor de verwachting is dat de stof in de praktijk geen probleem zal zijn, aangezien ook de mate van overschrijding klein is.

\section{Oordeel}

Uienpulp, gespoelde en uitgesorteerde zilveruien en uienwater voldoen aan normen voor zware metalen en arseen. Het is niet aannemelijk dat bij deze producten OM in ongewenst hoge gehalten aanwezig zullen zijn. Informatie over OOM is summier of ontbreekt en vraagt in beginsel nadere aandacht. Op dit beoordelingsaspect wordt teruggekomen bij de bespreking van de stand van zaken bij OOM.

Uienpellen en uienreststromen die vrijkomen bij het sorteren en verpakken van uien, kunnen de maximaal toegelaten vrachten flink overschrijden (Tabel 5). Er is onvoldoende zicht op de mate van variatie in de gehalten aan zware metalen en arseen in deze afvalstroom. Op basis van de huidige stand van zaken worden uienpulp, gespoelde en uitgesorteerde zilveruien en uienwater positief beoordeeld op de aspecten zware metalen en arseen en OM. OOM vraagt nadere aandacht. Uienpellen en uienreststromen worden negatief beoordeel op grond van de sterk wisselende gehalten aan zware metalen en arseen.

\subsection{Aardappelpersvezels}

Er werd geen informatie verstrekt. Er zijn twee dossiers beschikbaar over aardappelpersvezels. Eén dossier was incompleet, het andere geeft vrij volledige informatie.

Aardappelpersvezels resteren na verwijdering van aardappelzetmeel uit fabrieksaardappelen. Aardappelpersvezels worden onder andere geproduceerd door Nederlandse en Duitse industrieën. Door de aanwezigheid van koolhydraten, ruwe celstof en resten aardappelzetmeel draagt het restproduct bij aan de productie van biogas. Bij verantwoord landbouwkundig gebruik is er geen aanleiding om een negatief effect op de bodemkwaliteit te verwachten.

Het volume aardappelpersvezels wordt door Koppejan et al. (2009) geraamd op 395 kton/jaar.

\section{Zware metalen en arseen}

Gegevens van het incomplete dossiers wijzen uit dat voor $\mathrm{Cd}, \mathrm{Cu}, \mathrm{Hg}, \mathrm{Pb}$ en $\mathrm{Zn}$ de milieutoets wordt doorstaan; informatie ontbreekt voor $\mathrm{Cr}$, Ni en $\mathrm{Zn}$. Het complete dossier toont aan dat alle zware metalen m.u.v. Cd de milieutoets doorstaan. Cd overschrijdt net de norm (102\%).

Aardappelstoomschillen doorstaan deze milieutoets. Het is daardoor niet aannemelijk dat aardappelpersvezels voor $\mathrm{Cr}$, $\mathrm{Ni}$ en $\mathrm{Zn}$ de milieutoets niet zouden doorstaan. 


\section{Organische microverontreinigingen van de Meststoffenwet (OM)}

Informatie over PAK's en minerale olie ontbreekt. Het is niet waarschijnlijk dat deze contaminanten in aardappelpersvezels in zorgvragende gehalten aanwezig zijn. Overige contaminanten doorstaan de milieutoets.

\section{Residuen van gewasbeschermingsmiddelen en biociden (OOM)}

Residuen van gewasbeschermingsmiddelen en biociden werden zowel beoordeeld bij een verzoek voor opname in bijlage Aa van de URMW als in het kader van het hier gerapporteerde onderzoek. Eerst wordt het resultaat van de beoordeling van het verzoek $(A)$ gegeven. Deze beoordeling volgt het protocol en houdt nog geen rekening met afbraak van OOM tijdens vergisting. Vervolgens wordt het resultaat gegeven van de beoordeling op basis van de systematiek met alternatieven (B), waarbij rekening gehouden wordt met afbraak bij vergisting.

\section{A. Beoordeling verzoek}

Bij het verzoek met vrij volledige informatie is een uitvoerig analyserapport op OOM gegeven. Van alle gerapporteerde actieve stoffen wordt de detectielimiet gegeven. Omdat de analyseresultaten beneden de detectielimiet lagen $(<0,01 \mathrm{mg} / \mathrm{kg}$ aardappelpersvezel), heeft de CDM-werkgroep Toetsing Stoffen de milieutoets toegespitst op de werkzame stoffen waarvoor al een beleidsmatig vastgestelde streefwaarde (VR) voor bodem beschikbaar is ${ }^{31}$. Daarnaast is een verdere selectie gemaakt op die stoffen waarvoor ook een snel toegankelijke $\mathrm{DT}_{50}$-waarde (veld) beschikbaar was via de FOOTPRINTdatabase ${ }^{32}$. Dit was het geval voor ethoprofos, deltamethrin, oxamyl, pirimicarb, linuron, bentazon, metazachloor, MCPA en imidacloprid. Dit leidde voor deze stoffen tot toelaatbare maximale jaarvrachten voor landbouwbodem variërend van $0,031-8,3 \mathrm{~g} / \mathrm{ha}$.

Op basis van het stikstofgehalte $(2,76 \mathrm{~g} / \mathrm{kg})$ is een maximale jaarlijkse gift aan aardappelpersvezels van 90,6 ton/ha afgeleid. Dit leidt tot een (fictieve ${ }^{33}$ ) maximale jaarvracht van $0,906 \mathrm{~g} / \mathrm{ha}$ van de hiervoor vermelde stoffen als het gehalte van de stof in het product gelijkgesteld wordt aan de waarde van de gerapporteerde detectielimiet $(0,01 \mathrm{mg} / \mathrm{kg})$.

Vergelijking van deze (fictieve) maximale jaarvracht met de toelaatbare maximale jaarvracht voor de verschillende stoffen levert dan voor ethoprofos, deltamethrin, oxamyl, pirimicarb, en linuron afnemende (fictieve) overschrijdingsfactoren op, variërend van 296 - 9,9. Voor de overige vier stoffen is de (fictieve) overschrijdingsfactor lager dan 1. Op basis van deze toetsing voldoen aardappelpersvezels dus niet aan de milieuhygiënische eisen voor overige organische stoffen. Aardappelpersvezels voldoen echter wel aan de $\mathrm{GMP}^{+}$-bepalingen en daarom is de toelaatbare bijdrage van ethoprofos via aardappelpersvezels aan dierlijke mest bepaald waarbij voldaan wordt aan de maximaal toelaatbare jaarvracht. Dit leidt tot een (fictieve) maximale gift van 0,3 ton product/ha/jr (=90,6 ton / 296), die beduidend lager ligt dan volgens het Protocol de praktische relevant geachte ondergrens van 10 ton/ha.

Ook op basis van de vier andere stoffen ligt de (fictieve) maximale productgift onder deze ondergrens. Deze (fictieve) gift is daarmee onrealistisch laag. Dit leidt tot het oordeel dat aardappelpersvezels op basis van fictieve gehalten van vijf overige organische contaminanten, waarvoor een beleidsmatige streefwaarde (VR) voor bodem is vastgesteld, als ongeschikt beoordeeld worden. Deze overschrijdingsfactoren zijn gebaseerd op toepassing van de detectielimiet conform het Protocol Beoordeling Stoffen Meststoffenwet versie 2.1. Hierin ligt onzekerheid besloten: het werkelijke gehalte kan aanzienlijk lager zijn dan de detectielimiet van de toegepaste methode. In geval van ethoprofos is de marge echter circa een factor 300 (dat wil zeggen dat de detectielimiet een factor 300 lager zou moeten zijn dan de opgegeven detectielimiet van $0,01 \mathrm{mg} / \mathrm{kg}$ om verantwoord uitsluitsel te kunnen geven of deze actieve stof in zorgvragende gehalten voorkomt). Het is daardoor aannemelijk dat ethoprofos de maximaal toelaatbare jaarvracht overschrijdt, voor overige residuen is dat onzeker.

\footnotetext{
${ }^{31}$ O.b.v. het normenoverzicht op de website Risico's van stoffen (www.rivm.nl/rvs).

32 http://sitem.herts.ac.uk/aeru/iupac/index.htm

${ }^{33}$ Voor analyseresultaten beneden de detectielimiet wordt - conform afspraak met AKV - de (fictieve) waarde van de detectielimiet voor de toetsing gehanteerd.
} 
Wat betreft de beoordeling van de stoffen genoemd in Tabel 1, geeft alleen lambda-cyhalothrin een marginale overschrijding bij alternatief 1 en 3. Dit zou veroorzaakt kunnen zijn door de vrij hoge detectielimiet van $0,01 \mathrm{mg} / \mathrm{Kg}$. Om deze reden worden voor wat betreft de 12 onderzochte stoffen geen problemen verwacht. Ook gezien het feit dat het slechts om een marginale overschrijding gaat (overschrijdingsfactor van 1,1 ).

\section{B. Beoordeling op basis van de beoordelingssystematieken van dit onderzoek}

Metribuzin, deltamethrin, mancozeb, lambda-cyhalothrin, MCPA, metam-natrium, glyfosaat en esfenvaleraat zijn volgens de systematiek van dit rapport beoordeeld. Metribuzin, deltamethrin, mancozeb, lambda-cyhalothrin, MCPA, metam-natrium en esfenvaleraat doorstaan niet de milieutoets van het protocol (overschrijdingsfactoren respectievelijk 339, 165, 160, 563, 20, 389 en 29). Bij toepassing van alternatief 1 of 3 doorstaat lambda-cyhalothrin niet de milieutoets maar dit betreft een lichte mate van overschrijding (overschrijdingsfactor 1,1, berekeningsresultaat op basis van detectielimiet).

\section{Oordeel}

Aardappelpersvezels kunnen bijdragen aan de biogasproductie. De belasting met zware metalen en arseen en OM is doorgaans afdoende laag. Er zijn twee metingen over het Cd-gehalte. Eén meting leidt tot een $2 \%$ hogere vracht dan toegelaten. Dit wordt niet opgevat als belemmerend. Geprioriteerde actieve stoffen doorstaan de milieutoets bij toepassing van alternatieven 1 en 3 . Bij lambda-cyhalothrin is er sprake van een lichte mate van overschrijding.

Er is een aanwijzing dat ethoprofos de maximaal toelaatbare jaarvracht overschrijdt. Ethoprofos is niet geprioriteerd in dit onderzoek. Derhalve is gegevensverzameling en toepassing van alternatieven 1, 2 of 3 niet uitgevoerd. Het is niet bekend of deze nematicide daadwerkelijk in de aardappelvezel voorkomt. Gelet op het gebruik wordt verwacht dat het middel vooral aan de buitenkant van de aardappel hecht. Nader onderzoek wordt geadviseerd. Echter gelet op de onzekerheden rond het oordeel over ethoprofos zou overwogen kunnen worden of, totdat definitief uitsluitsel verkregen is over de schadelijkheid van de nematicide, het restproduct in bijlage Aa van de Uitvoeringsregeling geplaatst zou kunnen worden.

\subsection{Bierbostel}

Er is geen informatie verstrekt. Er is één dossier van bierbostel beschikbaar.

Bierbostel resteert van de klaring van mout. Mout wordt gemaakt door brouwgerst te kiemen. Bij het kiemen wordt zetmeel omgezet in suikers. De gerstekorrels worden daarop gedroogd, waarbij de moutkiemen worden verwijderd. De kiemloze korrels worden gemalen, verwarmd en bevochtigd. De suikers gaan daardoor in oplossing en worden uitgewassen. De uitgewassen suikers (wort) dienen de productie van bier. Na het uitwassen van de suikers resteert een eiwitrijk gerstrestant, dit is bierbostel. Bierbostel resteert bij elke vorm van bierproductie. De stof heeft diverse toepassingen, waarvan die voor diervoeding een belangrijke is.

Door de aanwezigheid van ruw eiwit, ruwe celstof en ruw vet kan bierbostel een bijdrage leveren aan de biogasproductie.

Bij verantwoord landbouwkundig gebruik is er geen aanleiding om een negatief effect op de bodemkwaliteit te verwachten van een digestaat afkomstig van vergisting van bierbostel.

Koppejan et al. (2009) ramen het volume bierbostel op 500 kton/jaar.

Zware metalen en arseen

Bierbostel doorstaat de milieutoets voor zware metalen en arseen. 


\section{Organische microverontreinigingen van de Meststoffenwet (OM)}

$\mathrm{Er}$ is geen informatie beschikbaar over de gehalten aan OM maar bij deze reststof is er op voorhand geen reden om aan te nemen dat deze gehalten in zorgvragende concentraties aanwezig zijn.

\section{Residuen van gewasbeschermingsmiddelen en biociden (OOM)}

Metsulfuron-methyl, pirimifos-methyl, deltamethrin, mancozeb, lambda-cyhalothrin, MCPA, glyfosaat, thiofanaat-methyl en esfenvaleraat zijn volgens de systematiek van dit rapport beoordeeld.

Metsulfuron-methyl, pirimifos-methyl, deltamethrin, mancozeb, lambda-cyhalothrin, MCPA, thiofanaatmethyl en esfenvaleraat doorstaan niet de milieutoets van het protocol (overschrijdingsfactoren respectievelijk 3909, 19.709, 3.266, 106, 112, 20, 91 en 115). Bij toepassing van alternatief 1 of 3 doorstaan metsulfuron-methyl, pirimifos-methyl en deltamethrin niet de milieutoets (overschrijdingsfactoren 10,3, 13,6 en 2,8.). Bij toepassing van alternatief 2 doorstaat pirimifos-methyl niet de milieutoets (overschrijdingsfactor 1,4 ).

\section{Oordeel}

Bierbostel kan bijdragen aan de biogasproductie. De belasting met zware metalen en arseen is afdoende laag, er is geen reden om aan te nemen dat bierbostel dat ook bestemd wordt voor veevoeding zorgvragende gehalten aan OM bevat. De aanname dat de partijen bierbostel bestemd voor vergisting ook zullen voldoen aan vereisten voor veevoeders kan niet generiek gesteld worden. Ook voor veevoer afgekeurde partijen bierbostel zullen als covergistingsmateriaal worden aangeboden.

Metsulfuron-methyl, pirimifos-methyl en deltamethrin doorstaan niet de milieutoets bij geen van de beschouwde systematieken. Bij metsulfuron-methyl en deltamethrin is dit gebaseerd op toepassing van MRL-waarden. Een reëel risico van overschrijding is daardoor lager waardoor residuen van deze actieve stoffen een beperkt risico vormen. Het resultaat bij pirimifos-methyl is gebaseerd op meetwaarden. Toetsing volgens het protocol geeft een forse overschrijding, bij toetsing volgens alternatieven 1 en 3 is er sprake van een overschrijdingsfactor van 13,6; bij toetsing volgens alternatief 2 is er nog steeds sprake van overschrijding van de maximaal toelaatbare vracht $(1,4)$. Beheersing van het pirimifos-methylgehalte in bierbostel is nodig om onbezorgd digestaat van vergisting van bierbostel te gebruiken. Zonder een vorm van beheersing wordt geadviseerd bierbostel niet op te nemen in bijlage Aa van de URMW.

\subsection{Maïsgluten}

Er is geen informatie aangeleverd over maïsgluten.

Maïsgluten is een bijproduct van de maïszetmeelindustrie. Een synoniem voor maïsgluten is maïsglutenmeel.

Het productieproces begint met droog schoonmaken van ontvangen maïs. Dit bestaat uit het zeven en wegzuigen van onzuiverheden en breukkorrels van korrelmaïs. De maïskorrels worden bevochtigd waardoor ze gaan zwellen. Hierbij kan een middel voor de bestrijding van micro-organismen worden toegevoegd ter voorkoming van bederf. Na zwelling vindt een eerste maling plaats. Daaropvolgend wordt de kiem van de korrel gescheiden. Een tweede maling vindt dan plaats. Vervolgens wordt gezeefd waarbij zetmeel en eiwit gescheiden worden van vezeldeeltjes. Daaropvolgend wordt het zetmeel van het eiwit gescheiden. De oplossing met eiwit wordt gefilterd en vervolgens gedroogd. Dit product is maïsgluten. Het is een gedroogd bijproduct van de bereiding van maïszetmeel dat in hoofdzaak uit gluten bestaat en dat wordt verkregen bij het afscheiden van zetmeel uit maïs. Het hoofdproduct is maïszetmeel, andere bijproducten van de productie van maïszetmeel zijn maïsweekwater (zwelwater), breukmaïs, maïsglutenvoer, kiemschroot, kiem, maïskiemolie en bewerkte producten zoals ethanol en gemodificeerd maïszetmeel.

Maïsgluten bevat een hoog aandeel eiwit en kan daardoor bij verantwoorde rantsoenering bijdragen aan de biogasproductie. 
Bondt en Meeusen (2008) ramen de hoeveelheid maïsgluten op 125 kton/jaar. Maïsgluten is een grondstof voor diervoeder. Maïsgluten wordt in Nederland geproduceerd maar er vindt in Nederland en in andere EU27-landen import ${ }^{34}$ plaats. Maïsgluten wordt vooral uit de Verenigde Staten van Amerika geïmporteerd en dat geldt ook voor de EU27.

\section{Zware metalen en arseen}

De gegevensverzameling over de belasting met zware metalen en arseen is niet volledig. Gegevens ontbreken over $\mathrm{Cr}$, $\mathrm{Ni}$ en As. Overige contaminanten doorstaan de milieutoets.

\section{Organische microverontreinigingen van de Meststoffenwet (OM)}

Er zijn geen gegevens getraceerd over de belasting met OM.

\section{Residuen van gewasbeschermingsmiddelen en biociden (OOM)}

Er zijn geen gegevens getraceerd over de belasting met OOM. Op basis van MRL voor glyfosaat doorstaat maïsgluten de milieutoets volgens het protocol en dus ook die van de alternatieven.

\section{Oordeel}

De gegevensverzameling is niet afdoende om tot een verantwoorde afweging te komen. Maïsgluten is een product dat vooral uit de VS wordt geïmporteerd. De VS verwerkt maïs uit de NAFTA ${ }^{35}$-regio. Er is onvoldoende zicht op gehalten aan $\mathrm{Cr}$ en $\mathrm{Ni}$ en het gebruik van OOM bij de teelten van korrelmaïs in de NAFTA regio om enig risico volledig uit te sluiten. Aanvullende informatie is nodig om daartoe over te gaan. Het wordt niet verwacht dat OM in zorgvragende gehalten zullen voorkomen indien het materiaal voldoet aan door de US Food and Drug Administration (FDA) gestelde voorwaarden. Op dit moment wordt geadviseerd om maïsgluten niet op te nemen in bijlage Aa van de URMW.

\subsection{Melasse (slib)}

Er is geen informatie aangeleverd over melasse(slib).

Melasse kan bij verschillende vormen van suikerbe- en verwerking ontstaan. De belangrijkste grondstoffen voor de winning van suiker zijn suikerriet en suikerbieten. Er zijn ook andere suikerhoudende stropen die onder de duiding van melasse verhandeld worden.

De productieprocessen waar bij suikerrietmelasse en suikerbietmelasse vrijkomen verschillen enigszins. Bietsuiker wordt in één stap uit bieten geproduceerd, rietsuiker in twee stappen uit suikerriet. Bij beide processen wordt het suikerrijke sap uit de biet (dunsap) of het suikerriet geëxtraheerd na verkleining van het gewas tot reepjes middels een diffusieapparaat, al dan niet gevolgd door een persproces, door pletten en/of mangelen. Het suikerrijke sap wordt gezuiverd door een carbonatatiestap door toevoeging van ongebluste kalk. Het gezuiverde suikerrijke sap wordt vervolgens ingekookt tot een suikerstroop waarbij - onder enting met suikerkristallen suikerkristallen gevormd worden die met centrifuges verwijderd worden. Het kristallisatieproces van suiker bij suikerbiet wordt doorgaans nog een tweede keer uitgevoerd. Bij rietsuiker worden twee of drie keer een kristallisatieproces uitgevoerd die telkens meer tijd vraagt i.v.m. de gewijzigde samentelling van de nog steeds suikerhoudende stroop. De eerste kristallisatiestap levert een betere suikerkwaliteit dan de tweede. De suiker van de derde kristallisatiestap wordt teruggevoerd naar die van de tweede stap. De stroop waaruit de suikerkristallen zijn verwijderd is de melasse ${ }^{36}$.

\footnotetext{
${ }^{34}$ Bij maïsgluten wordt door de NVWA scherper gecontroleerd nadat is vastgesteld dat illegale gentechmaïs geïmporteerd wordt. Chineese maïsgluten bleek verontreinigd te zijn met melanine en cyaanzuur.

${ }^{35}$ North American Free Trade Agreement, een overeenkomst tussen VS, Canada en Mexico.

${ }^{36} \mathrm{Bij}$ de productie van suiker uit suikerriet worden drie vormen van melasse verkregen. Door drie opeenvolgende processtappen, waarbij suiker uit de suikerstroop wordt gewonnen, ontstaan 'first molasses', 'second molasses' en 'blackstrap molasses'. Blackstrap molasses is feitelijk een geconcentreerde mineralenoplossing waaruit suiker zoveel als mogelijk door kristallisatie is verwijderd.
} 
De bietsuiker is dan gereed. Rietsuiker, die dan nog bonkig en kleverig is door de aanklevende stroop, ondergaat nog een bewerking (affinatiestap). Aanklevende stroop wordt via een carbonatatiestap of via een fosfatatiestap (fosforzuurtoevoeging) verwijderd. Na deze affinatiestap is de rietsuiker gereed voor verdere verwerking en vermarkting. Bij de affinatiestap komt een twee suikerhoudende stroop vrij die geraffineerde melasse wordt genoemd.

Om de ontwikkeling van microörganismen bij de suikerproductie in de fabriek te beheersen, worden stoffen toegepast die remmend werken. De in Nederland gebruikte stoffen worden niet als milieubezwaarlijk aangemerkt. Er is geen beeld van de stoffen die elders worden toegepast.

Bij opslag van melasse in silo's kan door bezinking een sliblaag ontstaan die melasseslib wordt genoemd. Het is een reststof die rijk is aan kaliumsulfaat dat door opslag, kristallisatie en bezinking als sediment afgezet wordt. Over dit afzettingsproces en in het bijzonder over de samenstelling van dit type slib zijn geen gegevens gevonden. Er is een melding dat slib van melasseopslag in België afgevoerd wordt als meststof naar Nederland (Van Dijk, 2008). De stof melasseslib wordt in de wetenschappelijke literatuur niet adequaat beschreven. Daardoor kan het slib niet betrokken worden bij de beoordeling.

Een dergelijke sliblaag kan ook ontstaan bij de opslag van vinasse. Vinasse is het restproduct van de vergisting van melasse tot bioethanol of tot bakkersgist. Die sliblaag is eveneens rijk aan kaliumzouten. De sliblaag bestaat onder meer uit (afgestorven) gistcellen. Die afgestorven biomassa van bioethanol productie wordt hier niet besproken, het betreft geen melasse.

Melasse wordt als grondstof aan stoffen toegevoegd. Een voorbeeld daarvan is gemelasseerde bietenpersvezels. Dergelijke mengsels met melasse worden eveneens niet beoordeeld. Grondslag van de beoordeling is dat als melasse geschikt is om als covergistingsmateriaal gebruikt te kunnen worden, dan vormen mengsels met andere toegelaten covergistingsmaterialen geen aandachtspunt.

Melasse dient als grondstof zeer variërende industriële productieprocessen. Bij de fermentatieindustrie wordt melasse gebruikt voor de productie van bakkersgist, lysine, citroenzuur, bioethanol, biobutanol). De farmaceutische industrie gebruikt melasse. Enzymproductie vindt plaats met gebruik van melasse. Melasse wordt gebruikt voor de productie van rum en sojasaus. Fouten of ongeschikte partijen melasse voor deze processen zullen leiden tot het zoeken naar alternatieve toepassingen. Vergisting t.b.v. de biogasproductie komt dan in beeld. Onbekend is waardoor deze partijen ongeschikt zijn geworden voor andere toepassingen. Deze beoordeling beperkt zich tot de grondstof melasse die geschikt is als grondstof voor industriële toepassingen.

Melasse bevat vooral suikers. Mits verantwoord gerantsoeneerd (ter voorkoming van een te snelle en te omvangrijk zuurvorming) kan een bijdrage geleverd worden aan de biogasproductie. Melasse wordt als grondstof veelvuldig ingezet bij andere fermentatieprocessen die producten opleveren die de VGI als belangrijke afzetmarkt hebben. Daardoor verloopt de afzet van melasse daar volgens certificeringskaders (GMP $/ \mathrm{HACCP})$. Literatuurstudie heeft geen uitsluitsel gegeven wat het lot is van melasse dat niet beantwoordt aan vereisten van deze certificeringskaders en met name om welk volume het dan gaat.

Melasse ${ }^{37}$ van rietsuiker wordt ingevoerd. In 2010 bedroeg het volume 176 kton. Melasse van suikerbiet werd zowel ingevoerd als uitgevoerd. Netto wordt meer uitgevoerd: 41 kton. Daarnaast werd netto 450 kton gemelasseerde bietenpulp ingevoerd. Waarschijnlijk betreft dit een onderschatting van de werkelijke volumes (CBS StatLine). Een raming voor de Nederlandse productie aan bietmelasse in 2010 is 211 kton melasse (op basis van gegevens van het CBS). PDV ${ }^{38}$ raamt de hoeveelheid beschikbaar gekomen melasse als diervoedergrondstof voor de periode 1 juli $2008 \mathrm{t} / \mathrm{m} 30$ juni 2009 op 257 kton.

\footnotetext{
${ }^{37} 100$ ton suikerbieten levert 13 ton witsuiker, 60 ton natte bietenpulp, 4 ton melasse en 7 ton schuimaarde. Ruwweg wordt gemiddeld $300 \mathrm{~kg}$ reststof uit de suikerindustrie per ha landbouwgrond aangevoerd.

${ }^{38} \mathrm{http}: / /$ www.pdv.nl/Imbinaries/veevoedergrondstoffen_2008-2009.pdf
} 
Gegevens over de samenstelling en met name de gehalten aan zware metalen en arseen, OM en OOM zijn schaars beschikbaar. Tot een vergaande vorm van datamontage is overgegaan, waarbij geen onderscheid aangebracht kan worden tussen suikerbietmelasse en rietsuikermelasse.

\section{Zware metalen en arseen}

Gegevens zijn afkomstig van verschillende bronnen. Er wordt een aanzienlijk bereik in waarden gerapporteerd. Gemiddelden zijn afgeleid voor de uitvoering van de milieutoets.

Melasse doorstaat de milieutoets voor zware metalen en arseen. Cu vormt hierop een uitzondering. Dit is een gevolg van het lage fosfaatgehalte ten opzichte van het gehalte aan stikstof. Stikstof bepaalt het landbouwkundig gebruik. Indien stikstof als grondslag voor de milieutoets gehanteerd wordt, dan doorstaat melasse ook voor $\mathrm{Cu}$ de milieutoets. Dit resultaat is gebaseerd op gemiddelde waarden voor de belasting met deze anorganische contaminanten.

\section{Organische microverontreinigingen van de Meststoffenwet (OM)}

Melasse doorstaat de milieutoets voor dioxine en PCB's, over andere OM zijn geen gegevens getraceerd.

\section{Residuen van gewasbeschermingsmiddelen en biociden (OOM)}

De toetsing heeft plaatsgevonden op basis van de 10 geselecteerde stoffen. Er is geen beeld van het gebruik van gewasbeschermingsmiddelen en biociden bij de teelt van rietsuiker. Deltamethrin, lambda-cyhalothrin, fenmedfam, metam-natrium en esfenvaleraat doorstaan niet de milieutoets van het protocol (overschrijdingsfactoren van respectievelijk 1.472, 403, 279, 139 en 1.037). Bij toepassing van alternatieven 1 en 3 doorstaan deltamethrin en esfenvaleraat niet de milieutoets (overschrijdingsfactoren van respectievelijk 1,3 en 1,3). Alle milieutoetsen zijn gebaseerd op de toepassing van MRL-waarden (zie Tabel B5.2).

\section{Oordeel}

Melasse doorstaat de milieutoets op basis van gemiddelde waarden voor zware metalen en arseen. Ook dioxines en PCB's doorstaan de milieutoets. Gegevens over PAK's en minerale olie ontbreken maar zorgvragende gehalten zullen naar huidige beeldvorming niet aanwezig zijn. Informatie over $\mathrm{HCH}^{\prime}$, drin's en DDT-DDD-DDE ontbreekt. Omdat rietsuikermelasse geteeld wordt in landen (bv. India, Vietnam) waar lindaan nog wel toegelaten is als pesticide, wordt het ontbreken van meetgegevens van de producten die in Nederland op de markt zijn, als een omissie aangemerkt. Melasse van suikerbieten van teelten in EU27 zal geen zorgvragende gehalten aan uitgefaseerde genoemde OM bevatten.

Melasse van Nederlandse teelten zal geen milieuhygiënisch knelpunt geven, gelet op de geselecteerde actieve stoffen indien alternatieven 1 of 3 worden gevolgd. De MRL-waarde biedt bescherming, werkelijke meetwaarden zullen aanzienlijk lager zijn.

Voor melasse van Nederlandse teelten is toepassing als covergistingsmateriaal verantwoord. Juist omdat in melasse een levendige handel plaatsvindt, waardoor import uit niet-Europese landen plaats vindt, wordt aanbevolen meer zicht te krijgen op de samenstelling en belasting met verontreinigende stoffen in melasse, met name in partijen rietsuikermelasse, die in Nederland aangeboden worden als covergistingsmateriaal. Informatie over het melasseslib ontbreekt eveneens. Over deze reststof kan een oordeel worden opgesteld als informatie over de samenstelling en belasting met verontreinigende stoffen, zoals zware metalen, arseen, OM en OOM beschikbaar komt.

\subsection{Raapschroot}

Informatie over raapschroot is niet aangeleverd.

Raapschroot is een verzamelbegrip voor het product dat resteert van de verwerking van raapzaad (Brassica rapa L.) of koolzaad (Brassica napus L.) tot olie. De olie komt vrij door zaad te persen. Dit levert olie voor toepassingen in levensmiddelen-, veevoedings- en chemische industrie en voor toepassing als grondstof voor biodiesel. De productie kan al op boerderijschaal plaatsvinden. Dat 
wordt gestimuleerd doordat olie sinds 2006 accijnsvrij verkocht mag worden, en ook op industriële schaal wordt olie gewonnen.

Schroot van koolzaad of raapzaad bevat ruw eiwit en ruwe celstof waardoor bijgedragen wordt aan de biogasproductie.

Het areaal koolzaad in Nederland in 2010 was 2.628 ha (CBS StatLine). Het areaal raapzaad in Nederland is beduidend lager dan dat van koolzaad. In 2010 werd op 2.610 ha koolzaad verbouwd waarvan 133 ha zomerkoolzaad. Het areaal raapzaad bedroeg 17 ha. De productie bedroeg een 12 kton. In EU27 werd in 2010 zo'n $6.10^{6}$ ha koolzaad verbouwd met Duitsland en Frankrijk als grootste producenten, gevolgd door Polen, Roemenië en Tsjechië (Eurostat database). De productie binnen de EU27 bedroeg 20.417 kton zaad (paragraaf 4.5). PDV ${ }^{39}$ raamt de hoeveelheid beschikbaar gekomen koolzaadschroot ${ }^{40}$, raapzaadschroot als diervoedergrondstof voor de periode 1 juli $2008 \mathrm{t} / \mathrm{m} 30$ juni 2009 op 1032 kton. Import van schroot bepaalt de markt.

\section{Zware metalen en arseen}

Informatie over arseen ontbreekt. De zware metalen doorstaan de milieutoets.

\section{Organische microverontreinigingen van de Meststoffenwet (OM)}

Alleen over benzo(a)pyreen is informatie aangetroffen. Deze OM doorstaat de milieutoets.

\section{Residuen van gewasbeschermingsmiddelen en biociden (OOM)}

Deltamethrin, mancozeb en glyfosaat doorstaan de milieutoets van het protocol en dus ook van de alternatieven.

\section{Oordeel}

Schroot van koolzaad of raapzaad (koolzaadschroot of raapschroot) doorstaat de milieutoets voor zware metalen. Informatie over arseen ontbreekt evenals over de gehalten aan OM (benzo(a)pyreen uitgezonderd). Er is op voorhand geen reden om de aanwezigheid van zorgvragende gehalten te beredeneren.

OOM blijken geen aandachtspunt. Schroot van koolzaad of raapzaad kan opgenomen worden in bijlage Aa van de URMW.

\subsection{Perspulp van cichoreiwortels}

Gegevens zijn verstrekt door een handelshuis. Daarnaast zijn literatuurgegevens erbij betrokken. Ten slotte zijn gegevens van perspulp van suikerbiet betrokken bij de beoordeling.

Perspulp van cichoreiwortelen ${ }^{41}$ (Cigarant) resteert bij de verwerking van cichoreiwortels tot inuline en fructose en bestaat uit het geperste snijdsel van cichoreiwortels. Het productieproces waarbij perspulp vrijkomt, is vergelijkbaar met het productieproces van bietenpersvezels die vrijkomen bij de verwerking van suikerbieten. Het wordt met dezelfde installaties uitgevoerd. Nadat cichoreiwortelen geschoond en gewassen zijn worden zij versneden, waarna in diffusietorens het snijdsel met warm water wordt geëxtraheerd. Het snijdsel wordt uitgeperst. Dit uitgeperste snijdsel is de perspulp. Het dunsap van diffusietorens en persen wordt verder bewerkt tot inuline. Deze bewerking verschilt van die van de productie van sucrose uit suikerbieten, maar heeft verder geen invloed op de samenstelling van de perspulp van cichoreiwortels.

\footnotetext{
${ }^{39}$ http://www.pdv.nl//mbinaries/veevoedergrondstoffen_2008-2009.pdf

${ }^{40}$ Inclusief schilfers van koolzaad en raapzaad

${ }^{41}$ Het product wordt verhandeld onder handelsnamen Cigarant ${ }^{\circledR}$, Cigarante, Ciprostar
} 
De reststof heeft door de aanwezigheid van koolhydraten, ruwe celstof en ruw eiwit waarde om gebruikt te worden als covergistingsmateriaal voor biogasproductie. De reststof komt vrij bij een goed gedefinieerd productieproces. De aard van de stof is eenduidig te omschrijven.

Bij verantwoord landbouwkundig gebruik is er geen aanleiding om een negatief effect op de bodemkwaliteit te verwachten.

In 2009 werd 195,6 kton cichoreiwortel geoogst (oogstraming LEI ${ }^{42}, 2011$ ). Indien een parallel getrokken wordt met de productie van bietenperspulp, dan zal circa 117 kton perspulp van cichoreiwortelen jaarlijks geproduceerd worden.

Waardegevende bestanddelen in perspulp van cichorei worden wel gegeven in technisch wetenschappelijke databestanden. Die vertonen grote gelijkenis, wat de indruk wekt dat de schaarse gegevens een hergebruik kennen. Informatie over belasting met zware metalen en arseen, OM en OOM is niet in literatuur te traceren. Een handelshuis heeft één analyseresultaat afkomstig van datamontage gegeven over waardegevende bestanddelen en zware metalen en arseen. Het gebruik van gewasbeschermingsmiddelen en biociden bij cichorei is lager dan het gebruik bij de teelt van suikerbieten. Het productieproces waarbij perspulp vrijkomt, is identiek aan dat van suikerbieten. De teelt vindt op dezelfde gronden plaats als suikerbieten. Bij deze beoordeling zijn daarom ook de bevindingen bij perspulp van suikerbieten betrokken.

\section{Zware metalen en arseen}

Cigarant doorstaat niet de milieutoets op zware metalen en arseen op basis van de analyseresultaten die het handelshuis heeft aangeleverd ( $\mathrm{Cd} 116 \%, \mathrm{Ni}^{43} 152 \%$ ). Perspulp van suikerbieten doorstaat wel deze milieutoets.

\section{Organische microverontreinigingen van de Meststoffenwet (OM)}

$\mathrm{Er}$ is geen informatie verstrekt over de gehalten aan OM. Er is op voorhand geen reden om aan te nemen dat deze OM aanwezig zijn, tenzij grondtarra aanwezig is. Het ruwasgehalte is $2 \%$ waaruit afgeleid kan worden dat grondtarra nauwelijks aanwezig is.

\section{Residuen van gewasbeschermingsmiddelen en biociden (OOM)}

$\mathrm{Er}$ is geen informatie gegeven over residuen van gewasbeschermingsmiddelen. De teelt is vergelijkbaar met die van suikerbieten. Er is een vergelijking gemaakt met de residuen van OOM die in suikerbieten kunnen worden aangetroffen.

Perspulp van suikerbieten is onderzocht op deltamethrin, lambda-cyhalothrin, fenmedifam, metamnatrium, glyfosaat en esfenvaleraat, allen op basis van MRL-waarden. Deltamethrin, lambdacyhalothrin, fenmedifam, metam-natrium en esfenvaleraat doorstaan niet de milieutoets van het protocol (overschrijdingsfactoren 2.298, 629, 436, 217 en 1.618). Op basis van alternatieven 1 en 3 wordt de milieutoets niet doorstaan voor deltamethrin, lambda-cyhalothrin en esfenvaleraat (overschrijdingsfactoren van 2,0, 1,2 en 2,1, berekeningen berusten op de toepassing van MRL-waarden).

\section{Oordeel}

Cigarant heeft de potentie om bij te dragen aan de biogasproductie. Eén analyse ${ }^{44}$ van het handelshuis wijst op een overschrijding van de milieucriteria voor $\mathrm{Cd}$ en $\mathrm{Ni}$. Indien gespiegeld wordt aan bietenpersvezels doorstaat perspulp van cigarant deze stap van de milieutoets. De belasting met contaminanten voorgeschreven door de Meststoffenwet is dan afdoende laag of wordt afdoende laag geacht (OM). Het resultaat van de milieutoets van de residuen van OOM is gebaseerd op toepassing MRL-waarden. Daardoor is een zekerheid ingebouwd die de mate van overschrijding van de vracht

\footnotetext{
42 LEI, 2011. Land- en tuinbouwcijfers 2010. http://www.lei.wur.nl/NL/publicaties+en+producten/LEIpublicaties

${ }^{43}$ Dit oordeel betreft het nikkelgehalte in persvezels. Poniedziałek et al. (2005) hebben vastgesteld dat het loof van cichorei meer nikkel accumuleert dan andere landbouwgewassen. Nikkelgehalten in wortels van cichorei waren vergelijkbaar of lager dan gehalten in wortels en knollen van andere landbouwgewassen. Loof van cichorei is niet betrokken bij het opstellen van het oordeel.

${ }^{44}$ Deze analyse betreft datamontage van analyses uitgevoerd door verschillende laboratoria.
} 
nuanceert. Het verdient aanbeveling om in samenhang met nader onderzoek naar de spreiding in waardegevende bestanddelen en verontreinigende stoffen bij bietenperspulp ook dergelijk onderzoek bij perspulp van cichoreiwortels uit te voeren. Tot uitsluitsel van dit onderzoek verkregen is, zou de stof in bijlage Aa geplaatst kunnen worden.

\section{$4.20 \quad$ Wei}

Er is geen informatie over wei aangeleverd.

Wei is een restproduct dat vrijkomt bij de productie van kaas. Na toevoeging van stremsel en zuursel aan kaas klonteren de eiwitten samen (wrongel). De wrongel wordt uitgeperst en het vocht van persing is de wei. Wei is een grondstof voor veel producten. Er kunnen meer dan 50 producten van wei worden gemaakt. Deze verschillende productieprocessen resulteren in onderscheidenlijke producten met onderscheidenlijke samenstellingen. Voorbeelden daarvan zijn caseïnerijke en caseïnearme producten en weiproducten waaruit lactose is verwijderd. Dit leidt tot een palet aan qua samenstelling zeer verschillende producten.

Wei bevat eiwit en lactose. Wei heeft daardoor o.a. betekenis als veevoer. Het vraagt een goede beheersing van het vergistingsproces om wei tot waarde te brengen als covergistingsmateriaal. Voorkomen dient te worden dat de ammoniumconcentratie of de verzuring te hoog oplopen. Indien de ammoniumconcentratie en de verzuring beheersbaar zijn, dan kan wei bijdragen aan de biogasproductie.

Bij een goed geleid vergistingsproces en met een sanitatiestap zoals voorgeschreven voor dierlijke bijproducten, mag het digestaat de bodemkwaliteit niet aantasten.

$\mathrm{PDV}^{45}$ raamt de hoeveelheid beschikbaar gekomen gedroogd weipoeder als diervoedergrondstof voor de periode 1 juli 2008 t/m 30 juni 2009 op 301 kton. Dit betreft import. In 2008 was het volume vast weipoeder 264 kton; het volume aan vloeibare vormen van wei bedroeg 407 kton.

Een volledig overzicht met waardegevende bestanddelen en verontreinigende stoffen van alle mogelijke weiproducten is niet verkregen. Het oordeel is gebaseerd op datamontage van gedroogde weiproducten.

\section{Zware metalen en arseen}

Op basis van een gemiddelde van vier analyses doorstaat weipoeder de milieutoets op zware metalen en arseen. Eén product is voorzien van een analyse die de milieutoets voor Cu en Ni niet doorstaat (respectievelijk $125 \%$ en $154 \%$ ). Dit product heeft t.o.v. andere gedroogde weipoeders een laag stikstof- en fosfaatgehalte terwijl de belasting met zware metalen en arseen vergelijkbaar is.

\section{Organische microverontreinigingen van de Meststoffenwet (OM)}

Er zijn geen gegevens over gehalten aan OM bekend maar op voorhand is er geen reden om de aanwezigheid van zorgvragende gehalten aan OM in wei of weiproducten aan te treffen. De veronderstelling hierbij is dat wei niet door een omstandigheid ongeschikt is geworden voor verwerking via andere processen.

\section{Residuen van gewasbeschermingsmiddelen en biociden (OOM)}

Het is onbekend in welke mate deltamethrin, metam-natrium, glyfosaat en esfenvaleraat voorkomen in gedroogde weipoeders. MCPA, op basis van MRL-waarde, doorstaat niet de milieutoets van het protocol (overschrijdingsfactor 5,8 ).

\footnotetext{
${ }^{45}$ http://www.pdv.nl/Imbinaries/veevoedergrondstoffen_2008-2009.pdf
} 


\section{Oordeel}

Wei vraagt een goede beheersing van de vergistingstechniek. Indien deze aanwezig is, dan heeft wei een perspectief als covergistingsmateriaal. Wei als grondstof dient diverse toepassingen waaronder die voor de productie van diervoeders. Indien wei voor dit doel toegepast wordt, is - gelet op de resultaten van de milieutoetsen - het niet aannemelijk dat er een zorgvragend risico verbonden is aan de toepassing van wei(poeder) als covergistingsmateriaal.

Aan de mate van overschrijding voor zware metalen en MCPA (gebaseerd op MRL) wordt geen bijzonder belang gehecht. Indien wei niet door een omstandigheid ongeschikt is geworden voor verwerking voor andere doeleinden dan covergistingsmateriaal, dan is er een perspectief voor opname in bijlage Aa van de URMW. Echter, het verdient aanbeveling om voor dit product meer gegevens te verzamelen, met name over de producten die bestemd worden voor biogasproductie.

\subsection{Slib dat vrijkomt bij de productie van salades}

Er is informatie beschikbaar gesteld van het voedingsmiddelenslib dat vrijkomt bij FanoFineFood te Oosterwolde.

Voedingsmiddelenslib is een afval- en reststof dat bij industriële verwerking van levensmiddelen en veevoedermiddelen frequent vrijkomt. De bekendste vorm is swill. In deze paragraaf wordt het voedingsmiddelenslib beoordeeld dat bij FanoFineFood te Oosterwolde vrijkomt. Deze paragraaf betreft het flotatieslib. Voor zuiveringsslib gelden de algemene bepalingen van de MW (UBMW en URMW). Flotatieslib kan ook aangemerkt worden als zuiveringsslib (artikel 1 , lid g, subleden $1^{\circ}$ en $2^{\circ}$ van het UBMW). In deze paragraaf wordt de stof beoordeeld en wordt niet ingegaan op de juridische aspecten.

Het flotatieslib is een restproduct van de productie van salades, sauzen en quiches. Plantaardige en dierlijke grondstoffen worden verwerkt tot levensmiddelen. Grondstoffen zijn aardappelen, halffabricaten van groenten, verse groenten, ingrediënten van sauzen en kruiden. De beschrijving van het productieproces is generiek (wassen, schillen, koken, koelen, mengen). Bedrijfswater van het reinigen van machines voor de productie van salades wordt opgevangen in een buffer. Dit afvalwater wordt opgepompt en over een zeef geleid waarbij grovere delen van resten salades worden verwijderd. Aan het gezuiverde afvalwater wordt een flocculant toegevoegd, waardoor resten van bestanddelen van salades samenklonteren en een drijflaag vormen. Dit is het flotatieslib.

Flotatieslibben komen ook vrij bij andere VGI-industrieën, grootkeukens, slachthuizen en vetvangers. Afhankelijk van de herkomst geldt een andere categorie volgens de EG-verordening voor dierlijke bijproducten.

Het volume van het flotatieslib van FanoFineFood is gering: circa 1 kton/jaar. Aarnink et al. (2000) raamden in 2000 het totale volume flotatieslib op 2000 kton. Boersma en Hemmes (2001) raamden de hoeveelheid nat flotatieslib uit de VGI op 30-50 kton/jaar.

Het slib bestaat uit bezinksel van de productieketen en bevat onder meer vetten. Een opgave van de samenstelling aan waardegevende bestanddelen is niet gegeven maar uit het stroomschema kan worden afgeleid dat zetmeel en vetten aanwezig zijn. Deze bestanddelen hebben waarde bij vergisting. Vooral aan de vethoudende flotatieslibben wordt een hoge biogasproductie toegekend. Hoewel informatie ontbreekt over de exacte samenstelling, wordt niet verwacht dat na een goed geleide vergisting het digestaat de bodemkwaliteit zal schaden.

\section{Zware metalen en arseen}

Vijf analyses van verschillende monsters voedingsslib van FanoFineFood doorstaan de milieutoets.

Generiek kan niet gesteld worden dat flotatieslib altijd deze milieutoets doorstaat. De Handreichung Biogasgewinnung und - Nutzung (FNR, 2006) meldt gehalten voor koper en zink die tot forse overschrijdingen van de milieutoets leiden. Voor Cu wordt een bereik in overschrijding van 335-544\% en voor $\mathrm{Zn}$ wordt een bereik in overschrijding van $674-1.662 \%$ gevonden. 


\section{Organische microverontreinigingen van de Meststoffenwet (OM)}

Het vetgehalte van het slib wordt niet gegeven. Dit belemmert de beoordeling van de gehalten aan OM omdat een aantal contaminanten uitgedrukt worden in $\mathrm{kg}$ vet. Desondanks wijzen de meetgegevens uit dat de milieutoets voor OM wordt doorstaan. Informatie over PAK's en minerale olie ontbreekt maar er is geen reden om aan te nemen dat deze contaminanten aanwezig zijn in zorgvragende gehalten.

Generiek kan niet gesteld worden dat flotatieslib altijd deze milieutoets doorstaat. Zo kunnen bij VGI oude frituurvetten en -oliën vrijkomen. Bij dergelijke reststromen is aanvullende informatie nodig over gehalten aan OM.

\section{Residuen van gewasbeschermingsmiddelen en biociden (ООM)}

Informatie over gehalten aan OOM ontbreekt.

\section{Oordeel}

Het flotatieslib van FanoFineFood te Oosterwolde, dat vrijkomt bij de reiniging van afvalwater van het schoonmaken van machines voor de productie van salades zal een bijdrage kunnen leveren aan de productie van biogas. Dit flotatieslib doorstaat de milieutoets voor zware metalen en arseen en OM of althans er is geen reden om de aanwezigheid van zorgvragende gehalten aan OM te veronderstellen. Informatie over gehalten aan OOM ontbreekt. Omdat alle reststoffen afkomstig zijn van levensmiddelen, wordt het risico van zorgvragende gehalten OOM gering geacht. Totdat definitief uitsluitsel verkregen is over de gehalten aan residuen van OOM zou het restproduct in bijlage Aa van de Uitvoeringsregeling geplaatst kunnen worden. Voor een generieke regeling dient informatie over gehalten aan OM uitsluitsel te geven of alle flotatieslibben van de VGI schoon en onverdacht zijn.

\subsection{Bloembollen en afval van sorteren van bloembollen}

Een generieke aanvraag voor alle reststromen uit de bloembollenteelt en - broei is door het Productschap Tuinbouw (PT) ingediend. De onderbouwing van het verzoek is uitgevoerd door het Praktijkonderzoek Plant \& Omgeving Bloembollen Bomen en Fruit (PPO-BBF). PPO-BBF heeft informatie voor bloembollen en afval van sorteren van bloembollen verstrekt (Belder, 2011a, 2011b). Naast deze informatie is een gegevensformulier betreffende afgebroeide tulpenbollen betrokken bij het onderzoek.

De reststoffen van bloembollen ${ }^{46}$ en afval van sorteren van bloembollen komt vrij bij alle telers van bloembollen en broeierijen van bloembolproducten. Het aantal teelten van bloembolgewassen is groot en divers. PPO-BBF heeft vijf reststromen geïdentificeerd die representatief zijn voor toepassing als covergistingsmateriaal.

Belder (2011a) meldt het volgende bij de selectie van de restmaterialen:

"De grootste stroom betreft restmaterialen uit de tulpenbroei. Dit zijn planten(delen) die uit een bol gegroeid 'getrokken' zijn maar niet verkoopbaar zijn. Uit de afbroei komen ook hele en halve bollen vrij maar vanwege een zeer beperkt middelengebruik is deze stroom niet onderscheiden van de tulpenbollen uit het veld omdat het middelengebruik daar veel hoger ligt. Tulp is het gewas met het grootste areaal buitenteelt van alle bloembolgewassen (zo'n 5000 ha in 2010) en na de teelt komen restmaterialen vrij. Dit zijn bollen die niet goed gegroeid zijn, zieke bollen, bolhuiden en pelresten.

Naast tulpen worden er ook veel lelies geteeld en afgebroeid waar veel restmaterialen van overblijven. In de meeste gevallen worden leliebollen na de teelt gespoeld en gesorteerd waarbij kleine bollen, schubben en wortelpruiken overblijven. Het is bekend is dat het gebruik van gewasbeschermingsmiddelen in de lelieteelt het hoogst is van alle bloembolgewassen. Een goedkeuring van restmateriaal van de lelieteelt wat betreft residuen van gewasbeschermings-

\footnotetext{
${ }^{46}$ In deze paragraaf wordt onder bloembollen alle bolgewassen gerangschikt inclusief bloemdragende knolgewassen.
} 
middelen zou dan moeten volstaan voor een generieke toelating voor covergisting van gewassen met een lager middelengebruik. Uit de leliebroei komen voornamelijk onverkoopbare takken met bladmateriaal vrij. Er blijven nauwelijks bollen over na de afbroei van lelie. Tijdens de afbroei van tulpen en lelies worden nauwelijks middelen gebruikt. Wel wordt soms pirimifos-methyl gebruikt om bollen te beschermen tegen schadelijke insecten tijdens de opslag.

Om naast bolgewassen ook een knolgewas mee te nemen - met wellicht een andere biogasopbrengst - is gekozen om restmateriaal uit de gladiolenteelt mee te nemen. Dit zijn gladiolenkralen die gegroeid en gebloeid hebben op het veld waarna ze met bovengronds gewas (en soms ook de knol) worden afgevoerd."

PPO-BBF heeft op grond van bovenstaande overwegingen de volgende vijf reststromen geïdentificeerd en geselecteerd voor identiteitsvastlegging en analyses op verontreinigende stoffen (zware metalen en arseen, OM en enkele OOM):

1. Restmateriaal tulpenteelt;

2. Restmateriaal tulpenbroei;

3. Restmateriaal lelieteelt;

4. Restmateriaal leliebroei;

5. Restmateriaal gladiolenteelt.

De beschrijving van de productieprocessen waarbij deze materialen resteren is de volgende. Deze beschrijvingen zijn overgenomen van Belder (2011a).

\section{Restmateriaal tulpenteelt}

Dit zijn bollen die niet goed gegroeid zijn, zieke bollen, bolhuiden en pelresten. In de tulpenteelt wordt een bepaalde maat bollen opgeplant met als doel dat deze tijdens een groeiseizoen van oktober/ november $\mathrm{t} / \mathrm{m}$ juni/juli een aantal maten groeien. Voorafgaand en tijdens de teelt wordt gewasbescherming toegepast. Tijdens de teelt wordt het gewas ook bemest. Bemesting is vrij standaard met hoofd- en sporenelementen. Voorafgaand aan de tulpenteelt worden de bollen standaard ontsmet. Voor gewasbescherming is een lijst bijgevoegd met toegelaten actieve stoffen die mogelijk zijn gebruikt (Bijlage 6). Alleen een beperkt deel van deze stoffen zal tijdens een teelt worden gebruikt, afhankelijk van ras, weer en voorkeur gewasbeschermingsmiddel. Overigens is de verwachting dat hoeveelheden actieve stoffen in deze reststroom zeer laag zullen zijn. Behalve bolontsmettingsmiddelen worden middelen over het gewas gespoten en de kans dat de middelen op bollen in de grond terecht komen is zeer gering. Ook worden veel middelen tijdens het groeiseizoen al afgebroken.

\section{Restmateriaal tulpenbroei}

Dit zijn planten die uit een bol gegroeid 'getrokken' zijn en hele en halve bollen. Voorafgaand aan de broei wordt alleen pirimifos-methyl toegepast tijdens de bewaring van tulpenbollen. Omdat stengel-, blad- en bloemmateriaal heel anders van samenstelling is dan bolmateriaal zijn de chemische analyses inclusief vergistbaarheidskarakteristieken in deze reststroom te bepalen exclusief tulpenbollen omdat deze al zijn opgenomen in restmateriaal tulpenteelt. Wel is apart van afgebroeide tulpenbollen het gehalte aan pirimifos-methyl bepaald.

\section{Restmateriaal lelieteelt}

De lelieteelt is vergelijkbaar met die van tulpen met als onderscheid dat het gewas eind maart - begin april geplant wordt en eind oktober of november wordt gerooid. Bij het oogsten worden wortels en bollen opgerooid en vervolgens gespoeld. De reststromen bestaan uit te kleine bollen en wortels. Tijdens het groeiseizoen wordt lelie bemest en wordt gewasbescherming toegepast. Bemesting is vrij standaard met hoofd- en sporenelementen. Voor gewasbescherming is een lijst bijgevoegd met actieve stoffen die mogelijk zijn gebruikt (Bijlage 6). Overigens is de verwachting dat hoeveelheden actieve stoffen in deze reststroom zeer laag zullen zijn omdat de meeste middelen over het gewas gespoten worden en/of tijdens het groeiseizoen afgebroken worden.

\section{Restmateriaal leliebroei}

Dit zijn onverkoopbare takken met bladeren. Ook bij deze reststroom zijn chemische analyses uitgevoerd exclusief bolmateriaal omdat bolmateriaal al is meegenomen in de reststroom lelie-veld 


\section{Restmateriaal gladiool}

Dit zijn gladiolenkralen die gegroeid en gebloeid hebben op het veld waarna ze met knol en bovengronds gewas worden afgevoerd. Voor gewasbescherming is een lijst bijgevoegd met actieve stoffen die mogelijk zijn gebruikt (Bijlage 6). Overigens is de verwachting dat hoeveelheden actieve stoffen in deze reststroom laag zullen zijn omdat de meeste middelen tijdens het groeiseizoen afgebroken worden.

Bloembolresten kunnen bijdragen aan de biogasproductie. Meetgegevens van de biogasproductie en kwaliteit van Belder (2011a) zijn samengevat in Tabel 6.

\section{Tabel 6}

Biogasproductie en methaangehalte van reststromen van bloembolgewassen (Belder, 2011a).

\begin{tabular}{lcc} 
Restmateriaal & Biogasproductie $\left(\mathrm{m}^{3} /\right.$ ton $)$ & Methaangehalte $(\%)$ \\
Tulpenteelt & 133 & 52,4 \\
\hline Tulpenbroei & 55 & 58,5 \\
\hline Lelieteelt & 64 & 53,6 \\
\hline Leliebroei & 70,4 & 57,6 \\
\hline Gladiool & 47 & 54,7 \\
\hline
\end{tabular}

De lage waarde voor de biogasproductie bij gladiool wordt toegeschreven aan het aandeel grond-tarra (ca. 50\%). Grondtarra vormt een aandachtspunt. Restmaterialen met grondtarra maken dergelijke materialen ongeschikt voor natte vergisting ${ }^{47}$.

De volumina restmateriaal bloembolgewassen worden niet door Belder (2011a, 2011b) gegeven. In 2010 bedroeg het areaal tulp 11.400 ha, lelies 4700 ha en gladiool 1.100 ha. De arealen narcissen, hyacinten en irissen bedroegen toen respectievelijk 1.800 ha, 1.400 ha en 300 ha (CBS StatLine). De arealen zijn de laatste tien jaar vrij constant. Bondt et al. (2010) ramen de volumina afval op 100 kton afval uit teelt en 14 kton uit broeierij.

Belder (2011a) heeft per reststroom één analyse op zware metalen en arseen, OM en enige OOM verstrekt. Daarnaast zijn meetgegevens van het gegevensformulier betrokken bij de milieutoetsen. De beoordeling van de OOM betreft de verstrekte gegevens en de benadering volgens bijlage 5 .

\section{Zware metalen en arseen}

Elk restmateriaal doorstaat de toets op zware metalen en arseen.

\section{Organische microverontreinigingen van de Meststoffenwet (OM)}

Er is geen informatie verstrekt over gehalten aan dioxines. Er is echter geen aanleiding om de zorgvragende gehalten aan dioxines te verwachten. De overige OM doorstaan de milieutoets. Hierop is één uitzondering. Lindaan in het restmateriaal van tulpenbroei doorstaat in één geval net niet de milieutoets. Dit uitsluitsel betreft toepassing van een opgegeven detectielimiet. Aan deze overschrijding wordt vooralsnog geen bijzondere betekenis gehecht. De Nederlandse bloembollenteelt strekt zich uit over alle continenten. Er is geen informatie beschikbaar over de actieve stoffen die elders (Chili, Argentinië, Zuid Amerika, Tasmanië, etc.) worden gebruikt. Meer informatie over de residuen van OOM met name voor bollen die elders worden geteeld en in Nederland worden afgebroeid is wenselijk.

\section{Residuen van gewasbeschermingsmiddelen en biociden (OOM)}

Onderscheid wordt aangebracht naar bloembollen (A) en bloembollenafval van broei (B). Er bestaan geen MRL's voor bloembollen. Daarom is er - als meetwaarden voor residuen in bollen ontbraken een inschatting gemaakt van de OOM concentratie in de bloembol op basis van de toedieningsdosering. De relatie tussen de dosering en de MRL voor uien is gebruikt om de concentratie in bloembollen in te schatten. Dit leidt mogelijk tot een onderschatting van de werkelijke concentratie.

\footnotetext{
${ }^{47}$ Voor droge vergisting is er een (beperkt) perspectief.
} 


\section{A. Bloembollen}

Pirimifos-methyl, deltamethrin, mancozeb, lambda-cyhalothrin, metam-natrium, thiofanaat-methyl en esfenvaleraat van bloembollen doorstaan niet de milieutoets volgens het protocol (overschrijdingsfactoren van respectievelijk 5.191, 845, 4.224, 889, 768, 3.621 en 92). Bij toepassing van alternatieven 1 en 3 doorstaan pirimifos-methyl, mancozeb en lambda-cyhalothrin niet de milieutoets (overschrijdingsfactoren voor beide alternatieven van 3,6, 1,4 en 1,7). Bij pirimifos-methyl berust deze milieutoets op meetwaarden, bij mancozeb en lambda-cyhalothrin op MRL-waarden.

\section{B. Bloembollenafval van broei}

Pirimifos-methyl, deltamethrin, mancozeb, lambda-cyhalothrin, metam-natrium, thiofanaat-methyl en esfenvaleraat van bloembollen doorstaan niet de milieutoets volgens het protocol (overschrijdingsfactoren van respectievelijk 5.357, 872, 8.719, 1.836, 15.853, 3.737 en 95). Bij toepassing van alternatieven 1 en 3 doorstaan pirimifos-methyl, mancozeb en lambda-cyhalothrin niet de milieutoets (overschrijdingsfactoren voor beide alternatieven van 3,7, 2,9 en 3,6). Bij pirimifos-methyl berust deze milieutoets op meetwaarden, bij mancozeb en lambda-cyhalothrin op berekende waarden.

\section{Oordeel}

Restmaterialen van de teelt van bloembolgewassen en -broei hebben een perspectief voor toepassing als covergistingsmateriaal mits het aandeel grondtarra gering is. De restmaterialen doorstaan de milieutoetsen voor zware metalen en arseen en OM. Informatie over dioxine ontbreekt maar deze contaminant wordt niet verwacht in dit type restmaterialen. Residuen van pirimifos-methyl verhinderen dat de milieutoets van het protocol of van de alternatieven 1 en 3 wordt doorstaan. Beheersing van het pirimifos-methylgehalte in restmaterialen van teelt en broei van bloembolgewassen is nodig om onbezorgd digestaat van vergisting van restmateriaal van bloembolgewassen te kunnen gebruiken. Zonder een vorm van beheersing wordt geadviseerd restmaterialen van bloembolgewassen niet op te nemen in bijlage Aa van de URMW.

Het gebruik van gewasbeschermingsmiddelen en biociden bij de teelt en broei van bloembolgewassen is hoog. In 2008 werd gemiddeld 41,9 kg actieve stof/ha gebruikt. Geselecteerde actieve stoffen geven een overschrijding aan van milieucriteria voor pirimifos-methyl. Aanbevolen wordt om ook de milieuhygiënische gevolgen van niet beoordeelde actieve stoffen in beeld te brengen.

\subsection{Glycerine van dierlijke herkomst}

$\mathrm{Er}$ is geen informatie verstrekt over de samenstelling van dit product. Er werd informatie verstrekt over de standpuntbepaling van de EU betreffende de vergisting van categorie drie producten van de Verordening dierlijke bijproducten ${ }^{48}$. Deze paragraaf toetst glycerine van dierlijke herkomst op milieuhygiënische consequenties bij toepassing als covergistingsmateriaal.

De glycerine komt vrij bij de verwerking van vetten van dierlijke herkomst tot biodiesel. Een schets van het productieproces van biodiesel van vetten van dierlijke herkomst is gegeven. Dierlijke vetten van onbekende herkomst en aard worden geschoond. De geschoonde vetten worden met methanol (ethanol), in tegenwoordigheid van $\mathrm{KOH}$ als katalysator, bewerkt waarbij biodiesel en glycerol geproduceerd worden. Vluchtige vetzuren storen de vorming van biodiesel. Dierlijke vetten bevatten meer vluchtige vetzuren dan koolzaadolie en vragen daardoor een voorbewerking met methanol, waardoor methylesters gevormd worden die de biodieselproductie niet storen. In een klaarpan wordt het mengsel van biodiesel en glycerol (glycerine) onder invloed van de zwaartekracht in twee lagen gescheiden. Ook door centrifugeren kan scheiding van deze twee lagen verkregen worden. De lichtere laag bevat de biodieselesters met methanol, de zwaardere laag bevat de glycerine en methanol, daarnaast is de katalysator $\mathrm{KOH}$ aanwezig. $\mathrm{KOH}$ wordt met zuur geneutraliseerd en de methanol wordt door verdamping teruggewonnen en hergebruikt in het productieproces. De overblijvende vloeistof is

\footnotetext{
${ }^{48}$ Verordening (EG) nr. 1069/2009 van het Europees parlement en de raad van 21 oktober 2009 tot vaststelling van gezondheidsvoorschriften inzake niet voor menselijke consumptie bestemde dierlijke bijproducten en afgeleide producten en tot intrekking van Verordening (EG) nr. 1774/2002 (verordening dierlijke bijproducten)
} 
de ruwe glycerine die als covergistingsmateriaal wordt aangeboden. Productieprocessen worden aangepast naar de grondstoffen. De grondstoffen met hulpstoffen bepalen de samenstelling en het voorkomen van glycerine. Bij een goed scheidingsproces zal een heldere oplossing verkregen worden waarvan de kleur varieert van een licht gele tot een donkerbruine kleur. De oplossing kan helder zijn maar ook opaak. De stof zal daardoor niet makkelijk van glycerine van plantaardige herkomst te onderscheiden zijn. Laboratoriumonderzoek zal de herkomst moeten duiden.

Glycerine is een waardevol product ter bevordering van de biogasproductie. Bij een goed geleid vergistingsproces zal het resulterende digestaat geen schade aan de bodemkwaliteit leveren.

De totale vetproductie in Nederland wordt door Luske en Blonk (2009) geschat op 56 kton. Dit vet vindt verwerking als levensmiddel, diervoeder, technische toepassingen (producten voor persoonlijke verzorging, papierrecycling, schoonmaakmiddelen, plastics, glij- en smeermiddelen, koelmiddelen) en energietoepassingen (biodiesel, elektriciteitsopwekking). Het volume aan glycerine van dierlijke herkomst is niet bekend, maar bedraagt hiervan een fractie. Bij een destructiebedrijf vindt een biodieselproductie op basis van dierlijk vet plaats. De glycerine wordt in een eigen vergistingsinstallatie verwerkt. De capaciteit daarvan gaat tot $50 \mathrm{kton} / \mathrm{jaar}$. Het digestaat wordt gedroogd en dient als bijstook. Het merendeel van de dierlijke vetten wordt door destructiebedrijven verwerkt. Het aandeel glycerine van dierlijk vet zal gering zijn (< 10 kton). Initiatieven om op grotere schaal dierlijk vet te gaan verwerken tot biodiesel worden ondernomen. Het volume zal daardoor groeien.

Informatie over de herkomst van de vetten die verwerkt worden is niet bekend. Er zijn gegevens over zware metalen en arseen bekend en enkele gegevens over gehalten aan OM van de reststof die middels een gegevensformulier aangemeld is voor opname in bijlage Aa van de URMW. Informatie over spreiding in gehalten van contaminanten ontbreekt. Bronnenonderzoek heeft enige gegevens opgeleverd over deze spreiding. Het oordeel is gebaseerd op datamontage.

\section{Zware metalen en arseen}

De glycerine van dierlijke herkomst van het gegevensformulier doorstaat de milieutoets niet voor Cd $(300 \%)$, $\mathrm{Ni}(136 \%)$ en As (480\%). Dit uitsluitsel is gebaseerd op de toepassing van detectiegrenzen. Het resultaat wordt veroorzaakt door naar verhouding hoge detectielimieten ten opzichte van lage gehalten aan stikstof en fosfaat.

Door toepassing van bronnenonderzoek is meer informatie over de waardegevende bestanddelen aangetroffen. Indien uitgegaan wordt van gemiddelden voor gehalten aan drogestof, stikstof en fosfaat dan wordt opnieuw de milieutoets niet doorstaan voor Cd (198\%) en As (318\%).

\section{Organische microverontreinigingen van de Meststoffenwet (OM)}

Informatie over aldrin, dieldrin, $\Sigma P C B$, fenantreen, fluorantheen, benzo(k)fluorantheen, benzo(a)pyreen) en minerale olie is gegeven. Door bronnenonderzoek zijn gegevens over dioxine hier aan toegevoegd. Deze contaminanten doorstaan de milieutoets voor OM. Voor overige microverontreinigingen is dat niet bekend. Omdat een volledig overzicht ontbreekt van de productieprocessen en van de grondstoffen van dierlijke herkomst wordt dit als een belemmering aangemerkt.

\section{Residuen van gewasbeschermingsmiddelen en biociden (OOM)}

Informatie over gehalten aan OOM ontbreekt. Omdat informatie ontbreekt over de herkomst van de dierlijke vetten wordt dit als een omissie aangemerkt. In het algemeen zullen van de geselecteerde gewasbeschermingsmiddelen en biociden geen residuen aangetroffen worden in dierlijk vet. Deltamethrin vormt hierop een uitzondering, omdat deze actieve stof ook toegepast wordt als diergeneesmiddel. Als de MRL voor deltamethrin wordt gebruikt, dan levert dat een overschrijdingsfactor op van 3.769 bij toepassing van de milieutoets van het protocol en 3,2 volgens de milieutoetsen van alternatieven 1 en 3.

\section{Oordeel}

Glycerine is een waardevol product voor biogasproductie. De beschikbare informatie van glycerine van dierlijke herkomst is incompleet. De milieutoets op de zware metalen en arseen wijst op forse overschrijdingen van normen. Daarnaast ontbreekt informatie over gehalten aan OOM, met name die welke betreffende diergeneesmiddelen. In samenhang met het ontbreken van informatie over de herkomst van dit product wordt negatief geadviseerd voor opname in bijlage Aa van de URMW. 


\subsection{Gersteslijpmeelpellets}

Op verzoek van het ministerie EZ is een herbeoordeling van gersteslijpmeelpellets uitgevoerd op basis van gegevens ingediend bij het ministerie LNV-DKI. Bij deze beoordeling zijn vergelijkbare stoffen betrokken. Dit betreft graanresten, een mengsel van graanresten met plantaardige glycerine van biodieselproductie, tarwevoergriespellets en gerstpellen.

De betrokken stoffen zijn bijproducten van de graanproducten en de verwerking van graan. Graan ondergaat een groot aantal be- en verwerkingsprocessen waarbij verschillende bijproducten en reststoffen ontstaan. De bijproducten vinden afzet als (grondstof voor) veevoeder; de reststoffen worden vaak toegepast als bijstook.

De procesbeschrijving waarbij graanresten (A), tarwevoergriespellets (B), gersteslijpmeelpellets (C), gerstpellen $(D)$ en het mengsel van graanresten met een plantaardige glycerine van biodieselproductie $(E)$ is door de indieners van verzoeken daartoe met een verschillend detail gegeven. De volgende beschrijvingen werden gegeven.

\section{A. Graanresten}

Graanresten ontstaan bij de industriële verwerking van graan (tarwe, gerst, rogge, haver en triticale). Na schonen, pletten en malen tot meel resteren graanresten. Deze graanresten worden bestemd voor verbranding of voor biogasproductie.

\section{B. Tarwevoergriespellets}

Tarwevoergriespellets komen vrij bij de bewerking van tarwe en rogge tot bloem bestemd voor de levensmiddelenindustrie (brood \& banket). Er wordt geen eenduidige omschrijving van de stof gegeven: Tarwevoergriespellets zijn pellets gemaakt van tarwe- en/of rogge bestanddelen, ontstaan door scheiding en afzeving tijdens de vermaling van tarwe. Tarwe en rogge uit Duitsland, Frankrijk, Zweden, Denemarken, Engeland en soms de VS. worden verwerkt tot producten voor levensmiddelen en diervoeders. Gedetailleerde productieschema's zijn gegeven, maar maken hierbij geen melding over het gebruik van hulpstoffen en hun aandeel (met uitzondering van stoom en water). Tarwe en rogge worden geconditioneerd en ondergaan een aantal niet nader beschreven bewerkingen waarbij gries, fijn stof van doorval door zeven, afgekeurde bloem, stof van stofzuiginstallaties, tarwevoerbloem, spoelbloem en gebroken tarwe en onkruidzaden vrijkomen. Deze reststromen zijn de grondstoffen van tarwegriespellets. Het aandeel gries, vooral bestaande uit zemelen, is circa $18 \%$ van 750.000 ton tarwe per jaar. Overige aandelen variëren van 0,02 tot 0,05\%. Circa $2 \%$ bestaat uit kleine stromen van fijn stof van doorval door zeven, afgekeurde bloem, stof van stofzuiginstallaties, tarwevoerbloem, spoelbloem en gebroken tarwe en onkruidzaden.

\section{Gersteslijpmeelpellets}

Gerst wordt geschoond van metaal via een magneet. Gerst wordt dan gepeld (gedopt) en opnieuw geschoond van metaal waarna opnieuw gepeld wordt. De geschoonde gerst is bestemd voor de levensmiddelenindustrie (gort, parelgort). De doppen worden verzameld. Vervolgens worden drie slijpbeurten uitgevoerd waarbij slijpmeel vrijkomt. Slijpmeel en doppen worden gemengd. Met een magneet worden eventuele metaaldelen verwijderd. Vervolgens wordt zonder toevoegingen gepelletiseerd. Gersteslijpmeelpellets worden als veevoeder afgezet en vallen onder GMP ${ }^{+}$-bepalingen.

\section{Gerstpellen}

Gerstpellen komen vrij bij de bewerking van brouwgerst op een mouterij. Na verwijdering van grove onzuiverheden bij de voorreiniging en een tweede zuivering op grove en fijne onzuiverheden wordt gerst ontdaan van de pellen. Het schonen wordt uitgevoerd met lucht. Het schonen dient de verwijdering van pellen, gebroken en halve korrels. Dit materiaal wordt verzameld en vormt gerstpellen.

\section{E. Mengsel van graanresten met een plantaardige glycerine afkomstig van biodieselproductie} Het mengsel bestaat voor $70 \%$ uit graanresten (tarwe, gerst, maïs) n afkomstig van Franse coöperatieven die granen schonen door middel van zeven. Daarnaast is $30 \%$ plantaardige vetemulsie aanwezig die afkomstig is van de biodieselproductie uit olie van oliehoudende zaden (koolzaad, 
raapzaad, sojaboon, zonnebloempit). De coöperaties schonen granen (gerst, tarwe en maïs) door middel van zeven. Daarbij komen de graanresten vrij. De resten bestaan uit kaf, strodeeltjes, kleine zaden en zetmeelstof. De graanresten worden door een Belgisch bedrijf verwerkt. Volgens het processchema worden de graanresten nogmaals gezeefd - eerst over $25 \mathrm{~mm}$ en daarna over $5 \mathrm{~mm}-$ en ontdaan van ijzer. De fractie die de zeef passeert wordt verkleind in een hamermolen zodat er in het eindproduct geen hele graankorrels aanwezig zijn en wordt dan gebruikt voor de productie van het mengsel. Deze gemalen graanresten staan nog niet op de positieve lijst. De plantaardige vetemulsie staat in bijlage Aa van de URMW (AE.1.). Het eindproduct is geen diervoeder en beantwoordt niet aan $\mathrm{GMP}^{+}$-bepalingen.

Tarwegries dient als grondstof diverse productiedoelen. Naast veevoeder wordt tarwegries de functie van tweede generatie grondstof gegeven voor de bioethanolproductie.

Het volume droge graanafvallen wordt door Bondt en Meeuwsen (2008) geraamd op 663 kton.

Gegevens over de samenstelling, gehalten aan waardegevende bestanddelen, zware metalen en arseen, OM en OOM is zeer onderscheidenlijk aangeleverd. In deze paragraaf worden de verschillende gegevensbronnen samengebracht en aangevuld met gegevens uit de literatuur.

\section{Zware metalen en arseen}

Genoemde producten doorstaan de milieutoets voor zware metalen en arseen.

\section{Organische microverontreinigingen van de Meststoffenwet (OM)}

De informatie over de belasting met OM is niet van alle producten bekend. Doorgaans wordt de milieutoets doorstaan. Hierop vormen twee producten een uitzondering. Lindaan doorstaat de milieutoets niet en bij één analyseresultaat vormt ook endrin een aandachtspunt. Deze resultaten zijn gebaseerd op toepassing van opgegeven detectielimieten. In het algemeen wordt graan uit de EU27 verwerkt waardoor noch lindaan noch endrin een aanwezig kan zijn.

\section{Residuen van gewasbeschermingsmiddelen en biociden (OOM)}

Gehalten aan OOM zijn voor tarwevoergriespellets zeer goed bekend. Voor andere stoffen is dit minder goed of geheel niet bekend. Metsulfuron-methyl, pirimifos-methyl, deltamethrin, mancozeb, lambdacyhalothrin, MCPA, thiofanaat-methyl en esfenvaleraat doorstaan niet de milieutoets van het protocol (overschrijdingsfactoren van respectievelijk 3.480, 17.545, 29, 95, 100, 18, 14 en 5). Metsulfuronmethyl en pirimifos-methyl doorstaan niet de milieutoets van alternatieven 1 en 3 (overschrijdingsfactoren respectievelijk 9,2 en 12,1); pirimifos-methyl doorstaat de milieutoets van alternatief 2 niet (overschrijdingsfactor 1,2 ). Het resultaat bij pirimifos-methyl is gebaseerd op meet-gegevens. Het resultaat van de milieutoets met metsulfuron-methyl is gebaseerd op een MRL-waarde.

\section{Oordeel}

Graanresten door staan de milieutoetsen voor zware metalen en arseen en OM. Bij OOM is er een aandachtspunt. Pirimifos-methyl doorstaat geen van de milieutoetsen. Dit is gebaseerd op meetgegevens.

De vracht aan pirimifos-methyl is te hoog. Beheersing van het pirimifos-methylgehalte in graanresten is nodig om onbezorgd digestaat van vergisting te kunnen gebruiken. Zonder een vorm van beheersing wordt geadviseerd graanresten niet op te nemen in bijlage Aa van de URMW.

\subsection{Koffiedik}

Een dossier met informatie is aangeleverd. De informatie is later aangevuld met nauwkeurigere waarden voor verontreinigende stoffen.

Koffiedik resteert nadat gebrande en gemalen koffiebonen onder druk met heet water zijn geëxtraheerd. Het koffie-extract is bestemd voor koffieautomaten. Het materiaal dat resteert is koffiedik. 
Koffiedik draagt bij aan de biogasproductie door de aanwezigheid van ruwe celstof, koolhydraten, ruw eiwit en ruw vet. Het digestaat van vergisting van koffiedik mag bij verantwoord landbouwkundig gebruik geen aanleiding geven tot een aantasting van de bodemkwaliteit.

Het volume koffiedik wordt door Koppejan et al. (2009) geraamd op 40 kton.

\section{Zware metalen en arseen}

Koffiedik doorstaat niet de milieutoets. Het fosfaatgehalte is zeer laag ten opzichte van stikstof (respectievelijk 0,2 $\mathrm{g} \mathrm{P}_{2} \mathrm{O}_{5} / \mathrm{kg}$ en $9,1 \mathrm{~g} \mathrm{~N} / \mathrm{kg}$ ) De reststof bevat dusdanig lage gehalten aan fosfaat dat $\mathrm{Cu}$ en $\mathrm{Zn}$ niet stap 2 van de milieutoets van het Protocol doorstaan. Toepassing van dit criterium voor fosfaat bij dergelijk lage gehalten leidt tot een onrealistische oordeelvorming omdat het gebruik van koffiedik bepaald wordt door stikstof. De verhoudingen $\mathrm{Cu} / \mathrm{N}$ en $\mathrm{Zn} / \mathrm{N}$ van koffiedik zijn lager dan die van de referentie dierlijke mest (dunne varkensmest). Bij verantwoord gebruik van het digestaat zullen de vrachten aan koper en zink binnen de gestelde normen blijven. Op basis van deze overweging, die afwijkt van het protocol, doorstaat koffiedik dit onderdeel de milieutoets.

\section{Organische microverontreinigingen van de Meststoffenwet (OM)}

Gehalten aan OM zijn gegeven. Koffiedik doorstaat de milieutoets. Lindaan vormt hierop de uitzondering. Dit resultaat is gebaseerd op het gebruik van de detectielimiet. Of lindaan nog gebruikt worden bij de teelt van koffie is niet bekend. Koffiebonen worden in de EU geïmporteerd. De detectielimiet zou een factor 2,5 lager moeten zijn om dit aspect uit te sluiten.

\section{Residuen van gewasbeschermingsmiddelen en biociden (OOM)}

Deltamethrin, mancozeb, lambda-cyhalothrin en pirimifos-methyl doorstaan niet de milieutoets volgens het protocol (overschrijdingsfactoren zijn respectievelijk 21, 7, 142 en 827). Deze gevolgtrekking is gebaseerd op meetgegevens. Koffiedik doorstaat wel de milieutoets van alternatieven 1, 2 en 3 .

Informatie over het gehalte aan cafeïne is gegeven. Dit betreft een detectielimiet $(0,05 \%)$. Niet bekend is in welke mate cafeïne bij een vergistingsproces wordt afgebroken. Cafeïne behoort niet tot de lijst met 10 geselecteerde actieve stoffen. Cafeïne vraagt nadere aandacht ${ }^{49}$.

\section{Oordeel}

Koffiedik heeft een perspectief voor toepassing als covergistingsmateriaal. Koffiedik doorstaat de milieutoetsen voor zware metalen en arseen en voor OM. Bij Cu en $\mathrm{Zn}$ wordt niet de milieutoets doorstaan. Dit is een gevolg van het zeer lage gehalte aan fosfaat. Onder inachtneming van landbouwkundige overwegingen t.a.v. het gebruik van het digestaat van vergisting wordt dit aspect van de milieutoets niet betrokken bij de oordeelvorming. Lindaan doorstaat eveneens de milieutoets niet. Dit resultaat is gebaseerd op een detectiegrens. Informatie van de aanvrager ${ }^{50}$ en van de producent ${ }^{51}$ waarbij koffiedik vrijkomt, geeft aan dat voor de onderhavige reststroom het risico van te hoge lindaangehalten nihil is. Koffiedik doorstaat de milieutoetsen van alternatieven 1 en 3 . Koffiedik kan daardoor in aanmerking komen voor opname in bijlage Aa van de URMW.

Cafeïne vormt een aandachtspunt. Deze studie geeft hierover geen afdoend uitsluitsel. Van cafeïne is bekend dat de stof goed oplost in water en bij anaërobe afvalwaterzuivering voor meer dan $90 \%$ wordt afgebroken (Froehner et al., 2011). Een grote en snelle mate van afbraak is nodig om cafeïne af te voeren als aandachtspunt. Dit aandachtspunt speelt ook bij de zuivering van afvalwater van huishoudens. Koffiedik zou voorlopig in bijlage Aa van de URMW opgenomen kunnen worden totdat generiek uitsluitsel over het lot van cafeïne in het milieu afdoende bepaald is.

\footnotetext{
${ }^{49}$ Indien het protocol gevolgd wordt, dan is bij 0,05\% de aanvoer van cafeïne bij gebruik van koffiedik als stikstofmeststof circa $13,7 \mathrm{~kg} / \mathrm{ha}$.

${ }^{50}$ Het rantsoen bestaat voor $20 \%$ uit koffiedik.

${ }^{51}$ De producent geeft aan alleen uitsluitend koffiebonen te accepteren die met in de EU toegelaten gewasbeschermingsmiddelen en biociden werden behandeld.
} 


\subsection{Bietenperspulp}

Gegevens zijn verstrekt door een handelshuis. Daarnaast zijn literatuurgegevens erbij betrokken.

Nadat suikerbieten geschoond en gewassen zijn worden zij versneden, waarna in diffusietorens het snijdsel met warm water wordt geëxtraheerd. Het snijdsel wordt uitgeperst. Dit uitgeperste snijdsel is de perspulp (bietenperspulp). Het dunsap van diffusietorens en persen wordt verder bewerkt tot suiker (sacharose). Bietenperspulp resteert na verwerking van suikerbieten tot suiker. Het bestaat uit het geperste snijdsel van suikerbieten nadat de suiker grotendeels is verwijderd.

Bietenperspulp bestaat uit koolhydraten, ruwe celstof en as en heeft daarmee een waarde om bij te dragen de biogasproductie. Bij een goed geleide vergisting van bietenperspulp mag het resulterende digestaat de bodemkwaliteit niet aantasten.

Bietenperspulp wordt - als veevoer - zowel in niet-gedroogde als in gedroogde vorm aangeboden. Bij de gegevensverzameling is gestandaardiseerd naar een drogestofgehalte van $260 \mathrm{~g} / \mathrm{kg}$. PDV ${ }^{52}$ raamt de hoeveelheid beschikbaar gekomen gedroogde bietenperspulp (ca. $900 \mathrm{~g}$ drogestof/kg) als diervoedergrondstof voor de periode 1 juli 2008 t/m 30 juni 2009 op 249 kton. Hiervan is 76 kton een binnenlandse grondstof en 173 kton is ingevoerd. In 2009 werd 5.441 kton suikerbieten geproduceerd in Nederland (Wijsman, 2011). Een raming bij 60\% pulpproductie is dan dat bij de suikerproductie tevens een volume van 3265 kton natte bietenperspulp wordt geproduceerd. In 2010 werd 456 kton gemelasseerde bietenpulp ingevoerd. Mengsels met melasse zijn niet betrokken bij de beoordeling van bietenperspulp (zie paragraaf 4.17).

Een handelshuis heeft één analyseresultaat afkomstig van datamontage gegeven over waardegevende bestanddelen en zware metalen en arseen. Deze gegevens zijn aangevuld met gegevens uit literatuuronderzoek.

\section{Zware metalen en arseen}

Bietenperspulp doorstaat niet de milieutoets op zware metalen en arseen op basis van de analyseresultaten die het handelshuis heeft aangeleverd (Cd 125\%, Zn 138\%). Literatuurgegevens wijzen op lagere gehalten aan $\mathrm{Cd}$ en $\mathrm{Zn}$. Indien deze literatuurgegevens betrokken worden bij deze milieutoets dan doorstaat perspulp van suikerbieten de milieutoets.

\section{Organische microverontreinigingen van de Meststoffenwet (OM)}

$\mathrm{Er}$ is geen informatie gegeven over gehalten aan OM. Er is bij dit product echter geen reden om de aanwezigheid van zorgvragende gehalten aan OM te veronderstellen.

\section{Residuen van gewasbeschermingsmiddelen en biociden (OOM)}

Perspulp van suikerbieten is onderzocht op deltamethrin, lambda-cyhalothrin, fenmedifam, metamnatrium, glyfosaat en esfenvaleraat, allen op basis van MRL-waarden. Deltamethrin, lambdacyhalothrin, fenmedifam, metam-natrium en esfenvaleraat doorstaan niet de milieutoets van het protocol (overschrijdingsfactoren 2.298, 629, 436, 217 en 1.618). Op basis van alternatieven 1 en 3 wordt de milieutoets niet doorstaan voor deltamethrin, lambda-cyhalothrin en esfenvaleraat (overschrijdingsfactoren van $2,0,1,2$ en 2,1 ).

\section{Oordeel}

Bietenperspulp heeft de potentie om bij te dragen aan de biogasproductie. Eén analyse ${ }^{53}$ van het handelshuis wijst op een overschrijding van de milieucriteria voor Cd en Zn. Literatuurgegevens wijzen niet op overschrijding van de milieutoets voor zware metalen en arseen. De belasting met contaminanten voorgeschreven door de Meststoffenwet is dan afdoende laag of wordt afdoende laag geacht (OM). Het resultaat van de milieutoets van de residuen van OOM is gebaseerd op toepassing MRL-waarden. Daardoor is een zekerheid ingebouwd die de mate van overschrijding van de vracht

\footnotetext{
52 http://www.pdv.nl/Imbinaries/veevoedergrondstoffen_2008-2009.pdf

${ }^{53}$ Deze analyse betreft datamontage van analyses uitgevoerd door verschillende laboratoria.
} 
nuanceert. Het verdient aanbeveling om nader onderzoek naar de spreiding in waardegevende bestanddelen en verontreinigende stoffen bij bietenperspulp uit te voeren om vast te stellen of zorgvragende hoge gehalten aan verontreinigende stoffen kunnen voorkomen. Tot uitsluitsel van dit onderzoek zou de stof voorlopig in bijlage Aa geplaatst kunnen worden.

\subsection{Aardappelstoomschillen}

Op verzoek van het ministerie EZ is een herbeoordeling van aardappelstoomschillen uitgevoerd.

Aardappelstoomschillen komen vrij bij fabrieken die aardappelen verwerken tot aardappelproducten (patat frites, chips, aardappelkroketten, geschilde aardappelen, etc.). Gegevens zijn afkomstig van vier producenten met in totaal acht productielocaties. De verstrekte informatie betreft voor deze producenten alleen het onderdeel van het productieproces, waarbij de aardappelen van de schil ontdaan worden, waardoor de stof vrijkomt. Er is geen informatie gegeven over overige productiehandelingen van de aardappelverwerkende industrie.

De verstrekte informatie is generiek. Aangevoerde aardappelen worden met water gewassen om aanhangende tarragrond te verwijderen. Daarna worden de aardappelen uitgesorteerd op basis van het soortelijk gewicht door middel van onderdompeling in een waterbad. Aardappelen die drijven worden afgevoerd. Volgens mededeling wordt aan het waterbad geen zout of klei toegevoegd. Bij één producent wordt antischuimmiddel toegevoegd, waarvan de dosering en het middel zijn gegeven. Aardappelen die niet gaan drijven, zijn geschikt voor verdere verwerking en worden vervolgens afgespoeld met schoon water. Daaropvolgend worden eventueel nog aanwezige stenen verwijderd. De geschoonde aardappelen worden voorverwarmd en worden vervolgens gestoomschild. Daartoe verblijven de aardappelen gedurende 10 à 25 seconden in een drukvat bij circa 16 bar en een temperatuur van circa $200^{\circ} \mathrm{C}$. De schil en een dun laagje van het onderliggende aardappelweefsel komen daardoor los te liggen en worden vervolgens van de aardappelen geborsteld. Dit product ondergaat een natuurlijke fermentatie, waardoor de $\mathrm{pH}$ daalt tot circa 3,5. Dit gefermenteerde product is aardappelstoomschillen.

Aardappelstoomschillen bevat gemiddeld $11 \%$ drogestof en $10 \%$ organische stof. Deze organische stof kan - deels - bijdragen aan de biogasproductie.

Het volume aardappelstoomschillen is door Koppejan et al. (2009) geraamd op 726 kton/jaar.

\section{Zware metalen en arseen}

Aardappelstoomschillen doorstaan de milieutoets voor zware metalen en arseen.

\section{Organische microverontreinigingen van de Meststoffenwet (OM)}

Aardappelstoomschillen doorstaan de milieutoets voor OM. Lindaan vormt hierop een uitzondering. Dit resultaat is het gevolg van het gebruik van een detectiegrens. Lindaan is in de EU27 uitgefaseerd. De grondstof aardappel is afkomstig uit EU27. Aan het resultaat van de milieutoets voor lindaan wordt geen belang gehecht.

\section{Residuen van gewasbeschermingsmiddelen en biociden (OOM)}

Aardappelstoomschillen doorstaan niet de milieutoets van het protocol voor metribuzin, deltamethrin, mancozeb, lambda-cyhalothrin, MCPA, metam-natrium en esfenvaleraat (overschrijdingsfactoren zijn respectievelijk 224, 71, 64, 371, 13, 257 en 19). Aardappelstoomschillen doorstaan de milieutoetsen van de alternatieven 1 en 3 en dus ook van alternatief 2 .

\section{Oordeel}

Aardappelstoomschillen kunnen bijdragen aan de biogasproductie. Het hoge vochtgehalte kan bij natte vergisting van betekenis zijn om covergistingsmaterialen met hoge drogestofgehalten te verdunnen. Aardappelstoomschillen doorstaan de milieutoetsen van alternatieven 1, 2 en 3 . Aardappelstoomschillen kunnen daardoor in aanmerking komen voor opname in bijlage Aa van de URMW. 


\subsection{Stillage}

Op verzoek van het ministerie EZ is een herbeoordeling van stillage uitgevoerd. De stillage betreft hier de reststof welke vrijkomt na vergisting van maïs ten behoeve van alcoholproductie middels het ZeaFuels-proces. Het is één van de vormen van productieprocessen van bioethanol voor biobrandstof. Stillage is een synoniem voor graanspoeling. Beide begrippen hebben betrekking op het bijproduct van de bioethanolproductie dat resteert nadat de ethanol (alcohol) door destillatie verwijderd is uit het vergiste beslag. In Nederland worden maïs en tarwe gebruikt voor bioethanolproductie. In het buitenland worden ook rogge, triticale en aardappelen gebruikt.

De bioethanolproductie van het ZeaFuels-proces verloopt als volgt. Maïskorrels worden na de oogst ingekuild. Ter conservering vindt behandeling plaats met propionzuur. Ten behoeve van de productie van de bioethanol worden ingekuilde maïskorrels gedurende $2-3$ uur tot $70-90^{\circ} \mathrm{C}$ verhit in water. $\mathrm{Na}$ verkleining wordt de maïs gevoed aan de fermentor. Daar worden met behulp van toegevoegde enzymen (amylases toegesneden op zetmeelbron van maïs) en gist (Sachromyces cerevisae, geselecteerde stam) en het zetmeel omgezet in suikers en vervolgens in ethanol. Na het reactieproces worden de grotere delen in het filter tegengehouden. Periodiek wordt het filter teruggespoeld met de vloeistof uit de bodemfractie van het destillatieproces. De vloeistof met de deeltjes is de stillage. Het betreft een gefilterde vorm van beslag van bioethanolproductie.

Het bovengenoemde proces is een voorbeeld van bioethanolproductie. De productie van bioethanol, met name door de toenemende vraag naar biobrandstoffen, neemt toe. Daardoor neemt, wereldwijd, de productie van graanspoeling toe. Een ander, gelijkend op hierboven gegeven productieproces is het volgende. De granen worden met (hamer)molens gemalen. Enzymen en water worden toegevoegd om zetmeel om te zetten tot suikers (dextrose). De brij (beslag) ondergaat een aantal processen van koken, liquefactie en koeling. Daarna volgt een fermentatiestap onder toevoeging van enzymen en gist waardoor via een biologisch proces ethanol (alcohol) wordt gevormd. Daarop vindt een destillatiestap plaats waarbij ethanol door afkoken wordt verwijderd. Ethanol wordt gestript en ondergaat verdere opwerking waarbij water verwijderd wordt. De reststof, graanspoeling of stillage, wordt met decanters gescheiden in een dikke fractie (wet cake of WDG ${ }^{54}$ ) en een dunne fractie (TS). De dunne fractie wordt geconcentreerd door een ontwateringsproces; dit proces levert CDS. WDG wordt gemengd met CDS en levert WDGS, Na drogen van WDGS levert dit DDGS-poeder. DDGS kan gepelletiseerd worden, wat dan DDGS-pellets levert. DDGS is het hoofdproduct, overige producten zijn bijproducten van de verwerking van bijproducten van bioethanolproductie.

Om het eindproduct te beschermen, wordt een scherpe controle uitgevoerd op de grondstoffen en het productieproces.

De hierboven gegeven productieprocessen betreffen de zogenoemde eerste generatie. Tweede generatie bioethanolproductieprocessen, bij voorbeeld door omzetting van cellulose tot ethanol, blijven hier onbesproken. $\mathrm{Er}$ is nog geen informatie beschikbaar over de samenstelling van de bijproducten van deze tweede generatie productieprocessen.

Graanspoeling, al dan niet in bewerkte vorm, kent diverse gebruiksdoelen. Afzet als veevoeder voor met name rundvee is een belangrijke afzet. Daarnaast vindt graanspoeling toepassingen als biobrandstof (verbranding, vergassing), kunstmest, toepassing als vezelbron en als grondstof in de levensmiddelenindustrie. Graanspoeling is in het algemeen $\mathrm{GMP}^{+}$-waardig.

\footnotetext{
${ }^{54}$ Graanspoeling is één van de bijproducten van bioethanolproductie. Dit bijproduct kan bewerkt worden. Het resterend materiaal na het afdestilleren van de ethanol (alcohol) kan worden gescheiden in een stapelbare vezelige fractie (wet distillers grains, WDG) en een dunne fractie (thin stillage, TS). De dunne fractie kan worden ingedampt (concentrated distillers solubles, CDS, of ook wel aangeduid met graangistconcentraat of tarwegistconcentraat of maïsgistconcentraat). WDS en CDS kunnen weer gemengd worden; dit levert wet distillers grains and solubles (WDGS). Een daarop volgend droogproces van WDGS levert het gedroogde product dried distillers grains and solubles (DDGS). Gedroogde producten worden geëxporteerd, natte producten vinden een afzet in de directe omgeving van de bioethanolfabriek. Het aanbod van DDGS op de wereldmarkt neemt toe.
} 
Graanspoeling bevat de resten van granen waaruit het zetmeel (grotendeels) is verwijderd. Het materiaal bevat onder andere het resterende ruwe eiwit en ruwe celstof naast biomassa van de gist. Deze bestanddelen geven graanspoeling een goed perspectief om te kunnen bijdragen aan de biogasproductie.

Bondt et al. (2009) geven een totale productie van reststromen uit de fermentatie-industrie op van 238 kton waarvan 223 kton een afzet vindt in de diervoederindustrie. Dit is naar de huidige beeldvorming een conservatieve raming. Het aanbod DDGS groeit door de groeiende productie van bioethanol.

Gegevens van een gegevensformulier stillage en van een verzoek voor DDGS, WDGS, CDS en TS aangevuld met enige gegevens uit de literatuur (met name waardegevende bestanddelen en gehalten aan $\mathrm{Cu}$ en $\mathrm{Zn}$ ) zijn beschikbaar. Gegevens over de gehalten aan OM zijn schaars en die voor OOM ontbreken vrijwel.

\section{Zware metalen en arseen}

Graanspoeling doorstaat de milieutoets.

\section{Organische microverontreinigingen van de Meststoffenwet (OM)}

Stillage van het Zeafuels-proces doorstaat de milieutoets. Bij graanspoeling van tarwe doorstaan dioxine, $\mathrm{HCH}^{\prime}$, drin's en DDT/DDD/DDE de milieutoets. Gegevens van andere OM ontbreken. In het algemeen mag er niet vanuit gegaan worden dat zorgvragende gehalten aan PAK's, PCB's of minerale olie in beslag van bioethanolproductie van graan aanwezig zijn.

\section{Residuen van gewasbeschermingsmiddelen en biociden (OOM)}

Gehalten aan OOM zijn voor graanspoeling vergelijkbaar met bierbostel en gersteslijpmeelpellets. Metsulfuron-methyl en pirimifos-methyl doorstaan niet de milieutoets van de alternatieven 1, 2 en 3 (overschrijdingsfactoren respectievelijk 31,4 en 41,3 voor alternatief 1 ). Het resultaat bij pirimifosmethyl is gebaseerd op meetgegevens. Het resultaat van de milieutoets met metsulfuron-methyl is gebaseerd op een MRL-waarde.

\section{Oordeel}

Graanspoeling komt vrij bij een productieproces waarbij kwaliteitsborging nadrukkelijk onderdeel uitmaakt van de bedrijfsvoering. Een milieuhygiënisch aandachtspunt, gelet op de resultaten van de milieutoets voor zware metalen en arseen en OM, wordt niet verwacht. Gegevens over OOM zijn nauwelijks beschikbaar. Er is geen directe aanleiding om zorgvragende gehalten te verwachten indien de kwaliteitsborging betrokken wordt bij het oordeel. Anderzijds is de informatie op dit punt te summier. Graanspoeling, met name de gedroogde vorm, wordt wereldwijd verhandeld. Meer informatie is nodig om de eventuele risico's verbonden aan OOM in graanspoeling in beeld te brengen. Beheersing van het pirimifos-methylgehalte in graanresten is nodig om onbezorgd digestaat van vergisting te kunnen gebruiken. Zonder een vorm van beheersing wordt geadviseerd graanresten niet op te nemen in bijlage Aa van de URMW.

\subsection{Samenvattend overzicht}

In paragrafen $4.2-4.28$ is een beoordeling per stof gegeven met toelichting. In Tabel 7 worden deze beoordelingen samengevat. Doorgaans zal de identiteit van een stof afdoende vast staan. Dat geldt niet voor alle beoordeelde stoffen door de grote verscheidenheid in samenstelling (bakkerijrestproducten) of door onduidelijkheden over het productieproces en/of herkomst (bermmaaisel, melasseslib, glycerine van dierlijke herkomst). Door verantwoorde vrachtbrieven zou de herkomst bekend moeten zijn.

De stoffen leveren alle - zij het niet in een gelijke mate - een bijdrage aan de biogasproductie en zijn ook in een anaëroob milieu afbreekbaar. De mate waarin bijgedragen wordt, is bij enkele stoffen gemeten of op basis van theoretische overwegingen afgeleid uit analyses van samenstellende bestanddelen. Dit onderdeel zou verder verdiept kunnen worden. 
De resultaten van de milieutoetsen worden in het kort verwoord. Voor een toelichting wordt verwezen naar de paragrafen 4.2 - 4.28. Indien een meetgegeven ontbreekt voor een microverontreiniging (zware metaal, arseen, OM en/of OOM) dan is met expert judgement ingeschat of daaraan een risico verbonden is. Er zijn aandachtspunten. Veel van de beoordeelde stoffen dienen de productie van levensmiddelen en veevoeders. Bij deze productie gelden strikte kaders van $\mathrm{GMP}^{+} / \mathrm{HACCP}$. Die kaders gelden niet voor de reststoffen die vrijkomen bij de productie, maar wel weer voor overproductie die tijdelijk niet als veevoeder kan worden afgezet. Die overproductie vindt dan een weg naar vergistingsinstallaties. GMP ${ }^{+} / \mathrm{HACCP}$ is evenmin van toepassing op grondstoffen die afgekeurd zijn voor toepassing bij levensmiddelen- en voederproductie of andere productieprocessen waarbij certificering toegepast wordt om de kwaliteit van eindproduct(en) te bewaken. Voorbeelden andere productieprocessen zijn de productie van suiker, gist, farmaceutica, (bio)ethanol en wijn.

Gegevens over zware metalen en arseen zijn doorgaans beschikbaar, enkele stoffen daargelaten. Er is in het algemeen geen verwachting dat bij de zuiver plantaardige en onbewerkte stoffen er een aanzienlijk risico is van milieuhygiënisch ongewenste vrachten van $\mathrm{As}$ of $\mathrm{Hg}$ bij verantwoord gebruik passend bij GLP. Bij bewerkte stoffen is risico niet volledig uit te sluiten, $\mathrm{Cr}$ en Ni kunnen daardoor qua gehalte verhoogd worden. Het ontbreken van gegevens is dan belemmerend bij het opstellen van een beoordeling.

Gegevens van OM ontbreken vaker. Bij de beschouwde stoffen wordt dit in het algemeen niet als belemmerend opgevat. Het wordt niet verwacht dat er een aanzienlijk risico is op milieuhygiënisch ongewenste vrachten. Dat risico is er wel als er grondstoffen worden aangevoerd van teelten buiten EU27 of beschrijvingen van productieprocessen te onvolkomen zijn. Voor stoffen die binnen de EU27 geproduceerd worden en waarbij de reststromen ontstaan, mag lindaan geen milieuhygiënische aandachtspunt zijn; het gewasbeschermingsmiddel is verboden en uitgefaseerd. Voor teelten buiten de EU27 blijft dat een aandachtspunt, lindaan vindt elders nog wel toepassingen. Een controle op gehalten met een afdoend lage detectiegrens is dan een voorwaarde om een verantwoorde beoordeling te kunnen opstellen. Indien een productieproces te onvolkomen wordt beschreven kan niet vastgesteld worden of er OM aanwezig zijn (bijvoorbeeld de vorming van PAK's door een niet beschreven verhittingsproces).

Gegevens over OOM ontbreken frequent. Ramingen van gehalten van geselecteerde residuen van OOM zijn gebruikt om de milieutoets volgens het protocol en volgens drie alternatieven uit te voeren. Opvolgen van het protocol leidt frequent tot een negatieve beoordeling. Alternatieven 1, 2 en 3 scheppen ruimte. De vracht wordt bepaald bij gebruik als stikstof- of fosfaatmeststof. Als alternatief 2 niet doorstaan wordt, ligt de oorzaak mede bij lage gehalten aan deze mineralen. Pirimifos-methyl vormt bij reststromen van diverse stoffen die bescherming nodig hebben tegen mijten, een milieuhygiënisch aandachtspunt. Een evaluatie van de gebruikte beoordelingswaarde, een normafleiding, is nodig.

Het milieuhygiënisch risico wordt mede bepaald door het volume van een covergistingsmateriaal. Een gering volume van een stof met één of enkele contaminanten met een beperkte mate van overschrijding van de milieutoets geeft gering risico ten opzichte van een stof met een groot volume en zelfde mate van overschrijdingen. Bij een zware mate van contaminatie verhogen ook stoffen met kleine volumina het milieuhygiënisch risico. Tabel 7 geeft het volume aan. Onderscheid is daarbij gemaakt tussen het geraamde volume als covergistingsmateriaal of het volume als grondstof voor andere toepassing (tussen haakjes gegeven). Het volume van de stoffen is doorgaans niet goed bekend. Gegevens over toepassingen als diervoedergrondstoffen van graanbijproducten en veekoeken (schorten, schilfers en gluten) wijzen op een relatief groot volume maar dat betreft enkele stoffen (graanresten, bietenperspulp en schroot van oliehoudende zaden). Bij andere stoffen lijkt dit volume aanzienlijk kleiner maar dit volume kan groeien als de markt voor covergistingsmaterialen aantrekt en kan concurreren met grondstofprijzen van de diervoederindustrie.

Tabel 7 scoort per product de identiteit, de betekenis voor biogasproductie en mogelijkheden voor afbraak, de milieutoets (zware metalen en arseen, OM, OOM) en samen met het volume wordt een algemene beoordeling gegeven. De beoordeling geeft aan of aan een criterium voldaan kan worden, in dat geval wordt een plusteken $(+)$ gegeven. Wordt niet aan een criterium voldaan, dan wordt een 
minteken (-) gegeven. Indien een plus- of minteken tussen haakjes staat ( $(+)$ of $(-))$ dan zijn er omstandigheden waar rekening mee gehouden dient te worden. Vervolgens wordt in de laatste kolom van Tabel 7 in samenhang met het volume een generiek uitsluitsel gegeven waarbij in voorkomende gevallen aanvullende noties gegeven worden om met name milieuhygiënische risico's te beheersen.

\section{Worst-case scenario zware metalen en arseen}

Verzamelde gegevens over gehalten aan zware metalen en arseen bieden een mogelijkheid om een worst-case scenario uit te voeren. Dit scenario berust op het combineren van minimumgehalten aan waardegegevende bestanddelen van stikstof en fosfaat met maximale waarden voor drogestof en verontreinigingen. Tabel 8 vat de resultaten samen. Scenario W geeft de worst-case benadering aan, scenario $G$ een benadering op een indicatieve waarde hetzij gebaseerd op één analyse hetzij gebaseerd op een door datamontage afgeleide samenstelling waarbij spreiding in meetgegevens ontbrak. In een aantal gevallen is een combinatie uitgevoerd, bv. bij de reststoffen van bollenteelt en -broei waren meerdere gegevens beschikbaar voor $\mathrm{Cu}$ en $\mathrm{Zn}$ en waardegevende bestanddelen maar voor overige zware metalen en arseen was slechts één meetgegeven beschikbaar. Bij melasse en bij koffiedik berust de milieutoets voor $\mathrm{Cu}$ en $\mathrm{Zn}$ - afwijkend van het protocol - op herleiding op het stikstofgehalte.

De hier uitgevoerde worst-case-scenario is een indicatie of door variatie in gegevens de resultaten van milieutoetsen drastisch gaan afwijken van bevindingen op basis van een gemiddelde. De gegevens laten niet toe om een verantwoorde gevoeligheidsanalyse uit te voeren bv. door waarden van gemiddelden met mediaanwaarden te vergelijken. Daartoe dient de gegevensverzameling - fors - te worden uitgebreid.

De worst-case benaderingen wijzen er op dat enkele stoffen zoals graanresten en graanspoeling een indicatie geven dat de belasting met zware metalen en arseen niet sterk varieert en daardoor ook niet de uitslag van de milieutoets (ontbrekende gegevens daargelaten). Ook de reststromen van de teelt van bloembolgewassen en broei geven een dergelijke indicatie zij het dat het aantal waarnemingen beperkt is (3 à 4).

Uienpulp en uiensap doorstaan elk de milieutoets. Wordt datamontage uitgevoerd, dan blijken deze stoffen een dusdanig afwijkende samenstelling te hebben dat een worst-case benadering niet tot een gelijk resultaat van de milieutoets komt in vergelijking met die van de individuele producten. Dit wordt ook gevonden bij de derivaten van wei. Dit is niet meer dan een indicatie dat productieprocessen leiden tot een onderscheidenlijke samenstelling met een daaraan verbonden onderscheidenlijke mate van belasting.

Combinatie van resultaten van milieutoetsen op basis van meetwaarden met de resultaten van milieutoetsen volgens een worst-case benadering wijzen erop dat met name forse overschrijdingen (>>100\%) het signaal afgeven dat de datamontage gegevensbronnen verbindt die door één of meerdere omstandigheden onderling sterk afwijkend zijn. Bij zonnebloempitten, bermmaaisel, uienpellen, aardappelpersvezel en wei komen overschrijdingen voor van meer dan $400 \%$.

Standaardisatie naar productieproces en van de reststroom is nodig om de mate van overschrijding beheersbaar te houden. 


\section{Tabel 7}

Overzicht van de resultaten van beoordeling. Het volume wordt onderscheiden naar gebruik als covergistingsmateriaal en tussen haakjes naar gebruik als grondstof voor veevoeder.

\begin{tabular}{|c|c|c|c|c|c|c|c|c|}
\hline \multirow[t]{2}{*}{$\mathrm{Nr}$} & \multirow[t]{2}{*}{ Product } & \multirow[t]{2}{*}{ Identiteit } & \multirow[t]{2}{*}{$\begin{array}{l}\text { Biogas- } \\
\text { productie en } \\
\text { afbraak }\end{array}$} & Milieutoets & & & \multirow{2}{*}{$\begin{array}{l}\text { Volume } \\
\text { kton } \\
\text { (kton grondstof) }\end{array}$} & \multirow[t]{2}{*}{ Beoordeling } \\
\hline & & & & $\begin{array}{l}\text { Zware metalen en } \\
\text { arseen }\end{array}$ & $\begin{array}{l}\text { Organische } \\
\text { microverontreinigingen } \\
M W\end{array}$ & $\begin{array}{l}\text { Residuen } \\
\text { gewasbeschermings- } \\
\text { middelen en biociden }\end{array}$ & & \\
\hline $1 a$ & $\begin{array}{l}\text { Zonnebloem- } \\
\text { pitten }\end{array}$ & + & + & $\begin{array}{l}+ \\
\text { geen gegeven voor As }\end{array}$ & $\begin{array}{l}+: \mathrm{a}-\mathrm{HCH}, \beta-\mathrm{HCH}, \mathrm{HCB} \\
\text {-: Lindaan } \\
\text { Geen gegevens voor } \\
\text { andere OM }\end{array}$ & Geen gegevens & Zie 1 b schroot & - \\
\hline $1 b$ & $\begin{array}{l}\text { Geëxtraheerd } \\
\text { zonnebloem- } \\
\text { Meel (schroot) }\end{array}$ & + & + & $\begin{array}{l}+ \\
\text { geen gegevens voor } \mathrm{Cr}, \mathrm{Ni} \\
\text { en As }\end{array}$ & Geen gegevens & Geen gegevens & $(494)$ & - \\
\hline 2 & Bermmaaisel & $(+)$ & + & $\begin{array}{l}\text { - generiek, } \\
\text { +individuele partijen }\end{array}$ & $\begin{array}{l}+ \text { generiek } \\
\text { - individuele partij OCDD }\end{array}$ & $\begin{array}{l}\text { (+) geen aanleiding om } \\
\text { risico's van OOM te } \\
\text { verwachten bij ecologisch } \\
\text { bermbeheer anders is } \\
\text { glyfosaat aandachtspunt }\end{array}$ & 225 & $(-)$ \\
\hline 3 & Hooi & + & + & + & $\begin{array}{l}(+) \text { gegevens ontbreken, } \\
\text { geen aanleiding om } \\
\text { risico's van OM te } \\
\text { verwachten. }\end{array}$ & $\begin{array}{l}(+) \text { geen aanleiding om } \\
\text { risico's van OOM te } \\
\text { verwachten. }\end{array}$ & $(218)$ & $(+)$ \\
\hline 4 & $\begin{array}{l}\text { Stro van } \\
\text { koolzaad }\end{array}$ & + & + & $\begin{array}{l}- \\
\text { Geen gegevens } \mathrm{Cr} \text {, Ni en } \\
\text { As }\end{array}$ & $\begin{array}{l}(+) \text { gegevens ontbreken, } \\
\text { geen aanleiding om } \\
\text { risico's van OM te } \\
\text { verwachten. }\end{array}$ & $\begin{array}{l}\text { - protocol } \\
\text { +alternatieven }\end{array}$ & $\begin{array}{l}(8,7, \mathrm{NL} \\
\text { productie })\end{array}$ & $(+)$ \\
\hline 5 & Tarwe & + & + & $\begin{array}{l}(+) \text { geen aanleiding om } \\
\text { risico's van } \mathrm{Hg} \text { en As te } \\
\text { verwachten. }\end{array}$ & $\begin{array}{l}(+) \text { gegevens ontbreken, } \\
\text { geen aanleiding om } \\
\text { risico's van OM te } \\
\text { verwachten. }\end{array}$ & - protocol en alternatieven & $\begin{array}{l}(26964) \text { Stro } \\
(14,8) \\
\text { GPS }\end{array}$ & - \\
\hline 6 & $\begin{array}{l}\text { Erwten (alle } \\
\text { producten) }\end{array}$ & $(+)$ & + & $\begin{array}{l}\text { geen gegevens voor } \mathrm{Cr} \text {, Ni } \\
\text { en } \mathrm{Pb} \text {, voor overige zware } \\
\text { metalen en arseen: } \\
+ \text { erwt, }\end{array}$ & $\begin{array}{l}(+) \text { gegevens ontbreken, } \\
\text { geen aanleiding om } \\
\text { risico's van OM te } \\
\text { verwachten. }\end{array}$ & $\begin{array}{l}\text { - protocol en }(+) \\
\text { alternatieven } 1 \text { en } 3\end{array}$ & $(22)$ & $(+)$ \\
\hline
\end{tabular}




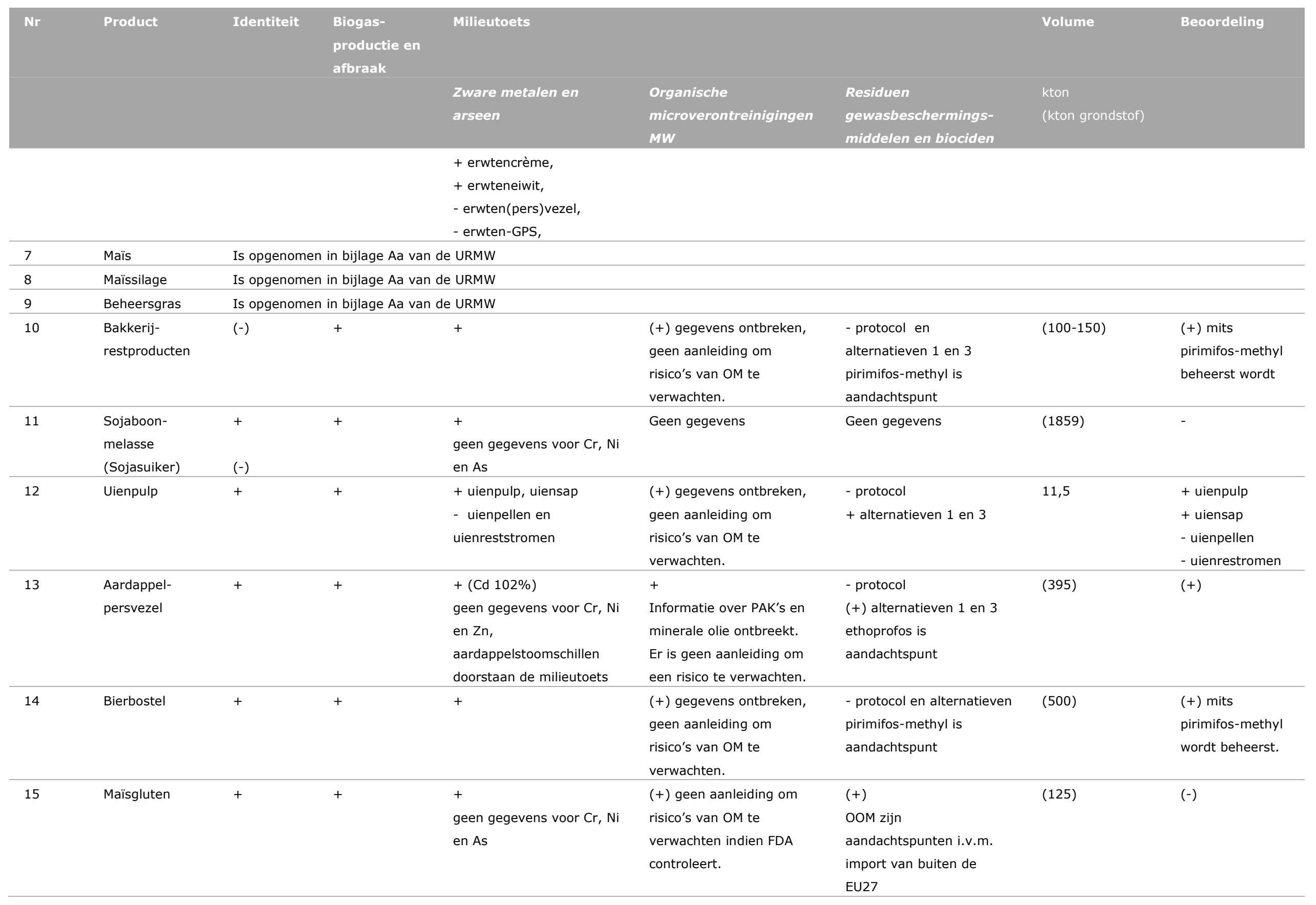

74 | wot-technical report 70 


\begin{tabular}{|c|c|c|c|c|c|c|c|c|}
\hline \multirow[t]{2}{*}{$\mathrm{Nr}$} & \multirow[t]{2}{*}{ Product } & \multirow[t]{2}{*}{ Identiteit } & \multirow[t]{2}{*}{$\begin{array}{l}\text { Biogas- } \\
\text { productie en } \\
\text { afbraak }\end{array}$} & \multicolumn{3}{|l|}{ Milieutoets } & Volume & \multirow[t]{2}{*}{ Beoordeling } \\
\hline & & & & $\begin{array}{l}\text { Zware metalen en } \\
\text { arseen }\end{array}$ & $\begin{array}{l}\text { Organische } \\
\text { microverontreinigingen } \\
\text { MW }\end{array}$ & $\begin{array}{l}\text { Residuen } \\
\text { gewasbeschermings- } \\
\text { middelen en biociden }\end{array}$ & $\begin{array}{l}\text { kton } \\
\text { (kton grondstof) }\end{array}$ & \\
\hline 16 & $\begin{array}{l}\text { Melasse } \\
\text { Melasseslib }\end{array}$ & $\begin{array}{l}+ \text { melasse } \\
- \\
\text { melassesli } \\
\text { b }\end{array}$ & $\begin{array}{l}+ \text { melasse } \\
\text { - geen } \\
\text { gegevens } \\
\text { voor } \\
\text { melasseslib }\end{array}$ & $\begin{array}{l}+ \text { melasse } \\
\text { - geen gegevens } \\
\text { melasseslib }\end{array}$ & $\begin{array}{l}\text { + bietmelasse } \\
\text { - rietmelasse en } \\
\text { melasseslib i.v.m. } \\
\text { ontbrekende gegevens- }\end{array}$ & $\begin{array}{l}\text { - riet- en bietsuiker- } \\
\text { melasse volgens protocol } \\
\text { + bietsuikermelasse } \\
\text { volgens alternatieven } 1 \text { en } \\
3 \\
\text { - rietsuikermelasse i.v.m. } \\
\text { ontbreken gegevens }\end{array}$ & $\begin{array}{l}(211) \\
\text { bietmelasse } \\
(176) \\
\text { rietmelasse }\end{array}$ & $\begin{array}{l}+ \text { bietmelasse } \\
- \\
\text { rietmelasse }\end{array}$ \\
\hline 17 & Raapschroot & + & + & + geen gegeven voor As & $\begin{array}{l}\text { + alleen benzo(a)pyreen } \\
\text { Geen aanleiding om } \\
\text { risico's van OM te } \\
\text { verwachten }\end{array}$ & + & $\begin{array}{l}(12) \mathrm{NL} \\
(1.032) \text { import }\end{array}$ & + \\
\hline 18 & $\begin{array}{l}\text { Perspulp van } \\
\text { cichoreiwortels }\end{array}$ & + & + & $\begin{array}{l}\text { - op basis van één } \\
\text { analyse } \\
+ \text { indien gespiegeld aan } \\
\text { perspulp van suikerbieten }\end{array}$ & $\begin{array}{l}(+) \text { gegevens ontbreken, } \\
\text { geen aanleiding om } \\
\text { risico's van OM te } \\
\text { verwachten. }\end{array}$ & $\begin{array}{l}(-) \text { protocol en } \\
\text { alternatieven } 1 \text { en } 3 \text { bij } \\
\text { toepassing van MRL- } \\
\text { waarden. }\end{array}$ & $(117)$ & $(+)$ \\
\hline 19 & Wei & $\begin{array}{l}+ \text { wei } \\
? \\
\text { weiderivat } \\
\text { en }^{55}\end{array}$ & + & $\begin{array}{l}\text { + (één product } \\
\text { uitgezonderd) }\end{array}$ & $\begin{array}{l}(+) \text { gegevens ontbreken, } \\
\text { geen aanleiding om } \\
\text { risico's van OM te } \\
\text { verwachten. }\end{array}$ & $\begin{array}{l}\text { - protocol } \\
+ \text { alternatieven }\end{array}$ & $\begin{array}{l}\text { (301) gedroogde } \\
\text { weipoeder }\end{array}$ & $\begin{array}{l}+ \text { beoordeelde } \\
\text { producten } \\
\text { ? overige } \\
\text { weiderivaten }\end{array}$ \\
\hline 20 & $\begin{array}{l}\text { Slib van de } \\
\text { productie van } \\
\text { salades }\end{array}$ & $\begin{array}{l}\text { - } \\
\text { flotatieslib } \\
\text { ben komen } \\
\text { vrij bij } \\
\text { diverse } \\
\text { processen. }\end{array}$ & + & $\begin{array}{l}\text { + onderhavige product } \\
\text { - generiek }\end{array}$ & + onderhavige product & $\begin{array}{l}(+) \text { geen aanleiding om } \\
\text { risico's van OOM te } \\
\text { verwachten. }\end{array}$ & $\begin{array}{l}1 \text { onderhavig } \\
\text { product } \\
30-50 \text { VGI }\end{array}$ & $\begin{array}{l}+ \text { onderhavige } \\
\text { product } \\
\text { - generiek }\end{array}$ \\
\hline 21 & $\begin{array}{l}\text { Bloembollen en } \\
\text { afval van het } \\
\text { sorteren van }\end{array}$ & + & $\begin{array}{l}+ \text { mits tarra- } \\
\text { aandeel } \\
\text { gering is }\end{array}$ & + & $\begin{array}{l}\text { + Nederlandse teelten } \\
\text { - Teelten elders }\end{array}$ & $\begin{array}{l}\text { - protocol en alternatieven } \\
1 \text { en } 3 \\
\text { pirimifos-methyl is }\end{array}$ & $\begin{array}{l}(100) \text { bol } \\
(14) \text { broeierij }\end{array}$ & $\begin{array}{l}(+) \text { pirimifos- } \\
\text { methyl dient } \\
\text { beheerst te }\end{array}$ \\
\hline
\end{tabular}

\footnotetext{
$\overline{55}$ Het aantal derivaten van wei is te groot om generiek een uitspraak te doen over de vastlegging van de identiteit.
} 


\begin{tabular}{|c|c|c|c|c|c|c|c|c|}
\hline \multirow[t]{3}{*}{$\mathrm{Nr}$} & \multirow[t]{2}{*}{ Product } & \multirow[t]{2}{*}{ Identiteit } & \multirow[t]{2}{*}{$\begin{array}{l}\text { Biogas- } \\
\text { productie en } \\
\text { afbraak }\end{array}$} & Milieutoets & & & \multirow{2}{*}{$\begin{array}{l}\text { Volume } \\
\text { kton } \\
\text { (kton grondstof) }\end{array}$} & \multirow[t]{2}{*}{ Beoordeling } \\
\hline & & & & $\begin{array}{l}\text { Zware metalen en } \\
\text { arseen }\end{array}$ & $\begin{array}{l}\text { Organische } \\
\text { microverontreinigingen } \\
\text { MW }\end{array}$ & $\begin{array}{l}\text { Residuen } \\
\text { gewasbeschermings- } \\
\text { middelen en biociden }\end{array}$ & & \\
\hline & bloembollen & & & & & aandachtspunt & & worden \\
\hline 22 & $\begin{array}{l}\text { Glycerine van } \\
\text { dierlijke } \\
\text { herkomst }\end{array}$ & $\begin{array}{l}\text { - tenzij } \\
\text { gebaseerd } \\
\text { op } \\
\text { (bio)chemi } \\
\text { sche } \\
\text { analyses }\end{array}$ & + & - & $\begin{array}{l}\text { + dioxine, aldrin, dieldrin, } \\
\Sigma P C B \text {, fenantreen, } \\
\text { fluorantheen, } \\
\text { benzo(k)fluorantheen, } \\
\text { benzo(a)pyreen) en } \\
\text { minerale olie } \\
\text { - overige } \\
\text { microverontreinigingen }\end{array}$ & $\begin{array}{l}\text { - protocol en alternatieven } \\
1 \text { en } 3\end{array}$ & $\begin{array}{l}\text { Onbekend maar } \\
\text { beperkt }<10 \\
\text { kton }\end{array}$ & - \\
\hline 23 & $\begin{array}{l}\text { Gersteslijpmeel } \\
\text { pellets } \\
\text { (Graanresten) }\end{array}$ & + & + & + & $\begin{array}{l}+ \\
\text { - lindaan }\end{array}$ & $\begin{array}{l}\text { - protocol, alternatieven } \\
\text { pirimifos is aandachtspunt }\end{array}$ & $(663)$ & $\begin{array}{l}(+) \text { mits } \\
\text { pirimifos-methyl } \\
\text { beheerst wordt. }\end{array}$ \\
\hline 24 & Koffiedik & + & + & $\begin{array}{l}\text { - bij opvolging protocol } \\
+ \text { indien gebruiksfunctie } \\
\text { gericht wordt op stikstof }\end{array}$ & $\begin{array}{l}+ \\
\text { - lindaan }\end{array}$ & $\begin{array}{l}\text { - protocol } \\
+ \text { alternatieven } \\
\text { Cafeïne is aandachtspunt }\end{array}$ & 40 & $\begin{array}{l}(+) \text { mits cafeïne } \\
\text { beheerst wordt. }\end{array}$ \\
\hline 25 & Bietenperspulp & + & + & $\begin{array}{l}\text { - op basis van één } \\
\text { analyse } \\
+ \text { indien gespiegeld aan } \\
\text { gegevens uit literatuur }\end{array}$ & $\begin{array}{l}(+) \text { gegevens ontbreken, } \\
\text { geen aanleiding om } \\
\text { risico's van OM te } \\
\text { verwachten. }\end{array}$ & $\begin{array}{l}\text { (-) protocol en } \\
\text { alternatieven } 1 \text { en } 3 \text { bij } \\
\text { toepassing van MRL- } \\
\text { waarden. }\end{array}$ & $(3.265)$ & $(+)$ \\
\hline 26 & $\begin{array}{l}\text { Aardappel- } \\
\text { stoomschillen }\end{array}$ & + & + & + & $\begin{array}{l}+ \\
- \text { lindaan }\end{array}$ & $\begin{array}{l}\text { - protocol } \\
\text { + alternatieven }\end{array}$ & $(726)$ & + \\
\hline 27 & $\begin{array}{l}\text { Stillage } \\
\text { (graanspoeling) }\end{array}$ & + & + & + & $\begin{array}{l}\text { + dioxine, } \mathrm{HCH} \text { 's, drin's } \\
\text { en DDT/DDD/DDE, geen } \\
\text { aanleiding om risico's van } \\
\text { OM te verwachten. }\end{array}$ & $\begin{array}{l}\text { - protocol, alternatieven } \\
\text { pirimifos-methyl is } \\
\text { aandachtspunt }\end{array}$ & (238) & $\begin{array}{l}(+) \text { mits } \\
\text { pirimifos-methyl } \\
\text { beheerst wordt }\end{array}$ \\
\hline
\end{tabular}

Betekenis van + en - is bij identiteit respectievelijk: identiteit eenduidig vast te stellen (+), identiteit is niet eenduidig vast te stellen $(-)$, bij biogasproductie en afbraak betekent

76 | wot-technical report 70 
Tabel 8

Overschrijding van de maximaal toelaatbare vracht in procent (tussen haken) indien de milieutoets volgens het protocol wordt uitgevoerd met minimumgehalten voor gehalten aan stikstof en fosfaat en maximaal gevonden waarden voor drogestof, zware metalen en arseen.

\begin{tabular}{|c|c|c|c|c|c|}
\hline $\mathrm{Nr}$ & Stof & Stof, gespecificeerd & Milieutoets $\mathrm{Cu}$ en $\mathrm{Zn}$ & Scenario & Resultaat \\
\hline \multirow[t]{2}{*}{$1 a, b$} & Zonnebloempitten - zaden & Zonnebloempitten - zaden & Fosfaat & W & Cd (435), geen gegeven As \\
\hline & & Geëxtraheerd zonnebloemmeel & Fosfaat & W & Geen gegevens $\mathrm{Cr}$, $\mathrm{Ni}$ en $\mathrm{As}$ \\
\hline \multirow[t]{9}{*}{2} & Bermmaaisel & Borculo & Fosfaat & W & $\begin{array}{l}\mathrm{Cd}(218), \mathrm{Cr}(136), \mathrm{Cu}(104), \mathrm{Ni}(179), \mathrm{Pb}(122), \mathrm{Zn} \\
(273), \mathrm{As}(240)\end{array}$ \\
\hline & & Eibergen & Fosfaat & W & $\mathrm{Cd}(138), \mathrm{Ni}(158), \mathrm{Zn}(164)$ \\
\hline & & Apeldoorn & Fosfaat & W & $\begin{array}{l}\mathrm{Cd}(191), \mathrm{Cu}(186), \mathrm{Hg}(129), \mathrm{Ni}(131), \mathrm{Pb}(104), \mathrm{Zn} \\
\text { (646), As (164) }\end{array}$ \\
\hline & & Regge \& Dinkel & Fosfaat & W & $\begin{array}{l}\text { Cd (257), Cr (111), Cu (293), Ni (172), Pb (143), Zn } \\
\text { (783), As (1286) }\end{array}$ \\
\hline & & Dinkelland & Fosfaat & W & $\mathrm{Cd}(100), \mathrm{Ni}(103), \mathrm{Zn}(149)$ \\
\hline & & Overijssel & Fosfaat & W & $\mathrm{Cd}(181), \mathrm{Pb}(148), \mathrm{Zn}(329)$ \\
\hline & & Hof van Twente & Fosfaat & W & (Cd (170), Cu (140), Zn (250), As (153) \\
\hline & & Noord-Brabant & Fosfaat & W & $\begin{array}{l}\mathrm{Cd}(239), \mathrm{Cr}(108), \mathrm{Cu}(307), \mathrm{Ni}(158), \mathrm{Pb}(342), \mathrm{Zn} \\
(246), \mathrm{As}(203)\end{array}$ \\
\hline & & Noord-Holland & Fosfaat & W & $\mathrm{Cd}(103), \mathrm{Pb}(120), \mathrm{Zn}(179)$, geen gegeven $\mathrm{Hg}$ \\
\hline 3 & Hooi & Hooi & Fosfaat & W & $\mathrm{Cr}(108), \mathrm{Ni}(285), \mathrm{Pb}(104), \mathrm{Zn}(240)$ \\
\hline 4 & Stro van koolzaad & Stro van koolzaad & Fosfaat & W/G & $\mathrm{Cd}(308)$ \\
\hline \multirow[t]{2}{*}{5} & Tarwe & Tarwe GPS & Fosfaat & W & Zn (152) \\
\hline & & Tarwestro & Fosfaat & W & Cd (164), Zn (116), geen gegevens $\mathrm{Hg}$ en As \\
\hline \multirow[t]{5}{*}{6} & Erwten & Erwt-GPS & Fosfaat & W & $\mathrm{Hg}(159)$, As (156), geen gegevens $\mathrm{Cr}$, Ni en $\mathrm{Pb}$. \\
\hline & & Erwtenvezel & Fosfaat & G & Zn (139), geen gegeven As \\
\hline & & Erwtenpersvezel & Fosfaat & G & Zn (347), geen gegeven As \\
\hline & & Erwtencrème & Fosfaat & G & Geen gegeven As. \\
\hline & & Erwteneiwit & Fosfaat & G & Geen gegeven As. \\
\hline \multirow[t]{6}{*}{10} & $\begin{array}{l}\text { Bakkerijrestproducten } \\
\text { (brood- en deegresten) }\end{array}$ & $\begin{array}{l}\text { Bakkerijrestproducten (brood- } \\
\text { en deegresten) }\end{array}$ & Fosfaat & G & $\mathrm{Cu}(168)$, gegevens $\mathrm{Cd}, \mathrm{Cr}, \mathrm{Hg}, \mathrm{Ni}, \mathrm{Zn}$ en As. \\
\hline & & Retour brood bakkerijen & Fosfaat & G & $\mathrm{Cd}(103)$ \\
\hline & & Broodproducten & Fosfaat & G & Geen gegevens $\mathrm{Cr}, \mathrm{Hg}$, $\mathrm{Ni}$ en As. \\
\hline & & Deeg & Fosfaat & G & Cd (103), geen gegevens $\mathrm{Cr}, \mathrm{Cu}, \mathrm{Ni}$ en $\mathrm{Zn}$. \\
\hline & & Brood en brooddeeg & Fosfaat & G & Geen gegevens \\
\hline & & Brood- en banket datamontage & Fosfaat & W & $\begin{array}{l}\mathrm{Cd}(394), \mathrm{Cr}(188), \mathrm{Cu}(274), \mathrm{Hg}(337), \mathrm{Ni}(304), \mathrm{Zn} \\
\text { (243), As (309) }\end{array}$ \\
\hline 11 & Sojaboonmelasse & Sojaboonmelasse of sojasuiker & Fosfaat & W & Cd (275), Zn (221), geen gegevens $\mathrm{Cr}$, Ni en As. \\
\hline \multirow[t]{3}{*}{12} & Uienpulp & Uienpulp & Fosfaat & G & \\
\hline & & Uiensap & Fosfaat & W & \\
\hline & & Uienreststromen (uienpellen) & Fosfaat & W & $\mathrm{Cd}(441), \mathrm{Cr}(265), \mathrm{Cu}(232), \mathrm{Hg}(118), \mathrm{Ni}(435), \mathrm{Pb}$ \\
\hline
\end{tabular}




\begin{tabular}{|c|c|c|c|c|c|}
\hline $\mathrm{Nr}$ & Stof & Stof, gespecificeerd & Milieutoets $\mathrm{Cu}$ en $\mathrm{Zn}$ & Scenario & Resultaat \\
\hline & & & & & (105), Zn (4382), As (575) \\
\hline & & $\begin{array}{l}\text { Uienrestproducten datamontage } \\
\text { excl. pellen }\end{array}$ & Fosfaat & W & $\begin{array}{l}\mathrm{Cd}(530), \mathrm{Cr}(320), \mathrm{Cu}(281), \mathrm{Hg}(139), \mathrm{Ni}(523), \mathrm{Pb} \\
(126), \mathrm{Zn}(975), \mathrm{As}(695)\end{array}$ \\
\hline \multirow[t]{3}{*}{13} & Aardappelpersvezels & Aardappelpersvezels & Fosfaat & G & Geen gegevens $\mathrm{Cr}, \mathrm{Hg}, \mathrm{Zn}$ en As. \\
\hline & & Aardappelvezel & Fosfaat & $(W)$ & $\mathrm{Cd}(127)$ \\
\hline & & $\begin{array}{l}\text { Aardappelpersvezels, } \\
\text { datamontage }\end{array}$ & Fosfaat & W & $\mathrm{Cd}(468), \mathrm{Cu}(676), \mathrm{Zn}(1188)$ \\
\hline 14 & Bierbostel & Gerstsubstraat (Bierbostel) & Fosfaat & W & Cd (383), Hg (130), Zn (152) \\
\hline 15 & Maïsgluten & Maïsgluten & Fosfaat & W & Geen gegevens $\mathrm{Cr}$, $\mathrm{Hg}$ en As. \\
\hline 16 & Melasse & Melasse & Stikstof & w & $\mathrm{Cd}(288), \mathrm{Cu}(143), \mathrm{Ni}(120)$ \\
\hline 17 & Raapzaadschroot & Raapzaadschroot & Fosfaat & w & Geen gegevens As. \\
\hline 18 & Perspulp van cichoreiwortel & Perspulp van cichoreiwortel & Fosfaat & $(W) / G$ & Cd (119), Ni (156) \\
\hline \multirow[t]{2}{*}{19} & Wei & Weipoeder derivaten (SCAL) & Fosfaat & w & $\mathrm{Cu}(342), \mathrm{Ni}(381)$ \\
\hline & & Wei gestandaardiseerd & Fosfaat & w & Cd (102), Cu (242), Ni (381), Zn (533) \\
\hline 20 & Voedingsmiddelenslib & $\begin{array}{l}\text { Voedingsmiddelen slib } \\
\text { (FanoFineFood) }\end{array}$ & Fosfaat & W & Cd (107) \\
\hline \multirow[t]{7}{*}{21} & $\begin{array}{l}\text { Bloembol- en } \\
\text { bloembolresten }\end{array}$ & Tulp-broeierij-loof & Fosfaat & W/G & \\
\hline & & Tulp-veld & Fosfaat & W/G & \\
\hline & & Lelie-broeierij & Fosfaat & W/G & \\
\hline & & Lelieveld gespoeld & Fosfaat & W/G & \\
\hline & & Gladiool & Fosfaat & W/G & $\mathrm{Cu}(182), \mathrm{Zn}(310)$, As (109) \\
\hline & & Tulpenbollen & Fosfaat & W/G & \\
\hline & & Tulpenblad & Fosfaat & W/G & \\
\hline 22 & $\begin{array}{l}\text { Glycerine van dierlijke } \\
\text { herkomst }\end{array}$ & Glycerine van dierlijke herkomst & Fosfaat & G & Cd (198), As (318) \\
\hline \multirow[t]{6}{*}{23} & Graanresten & Graanresten & Fosfaat & W & \\
\hline & & Biograanmix & Fosfaat & W & \\
\hline & & Tarwevoergriespellets & Fosfaat & W/G & \\
\hline & & Gersteslijpmeelpellets & Fosfaat & G & \\
\hline & & Gerstpellen & Fosfaat & w & As (112) \\
\hline & & Graanresten datamontage & Fosfaat & w & \\
\hline 24 & Koffiedik & Koffiedik & Stikstof & G & \\
\hline 25 & Bietenperspulp & Bietenperspulp & Fosfaat & W & Cd (137), Zn (177) \\
\hline 26 & Aardappelstoomschillen & Aardappelstoomschillen & Fosfaat & W & $\mathrm{Cu}(150)$ \\
\hline \multirow[t]{3}{*}{27} & Graanspoeling (stillage) & $\begin{array}{l}\text { Maïsfermentatieresten van } \\
\text { Zeafuels-proces }\end{array}$ & Fosfaat & G & \\
\hline & & Graanspoeling literatuur & Fosfaat & W/G & Geen gegevens $\mathrm{Cr}, \mathrm{Hg}$, $\mathrm{Ni}$ en $\mathrm{As}$. \\
\hline & & DDGS & Fosfaat & G & Geen gegevens $\mathrm{Cr}$, $\mathrm{Cu}$ en $\mathrm{Ni}$. \\
\hline
\end{tabular}

78 | wot-technical report 70 


\subsection{Beoordeling van afval- en reststoffen}

Op verzoek van het ministerie EZ is tevens een herbeoordeling uitgevoerd van de afval- en reststoffen die aanvankelijk een negatief oordeel hadden gekregen (119 stoffen). Een negatief oordeel kan het gevolg zijn van geen of onvoldoende gegevens. Ook kunnen onvoldoende gegevens verstrekt zijn, maar werd op basis van beschikbare gegevens in een aantal gevallen toch een negatief oordeel gegeven worden omdat vastgesteld werd dat op basis van beperkte meetgegevens de milieutoets op onderdelen niet doorstaan werd. Tabel 9 maakt dit inzichtelijk voor de milieutoets voor gehalten aan zware metalen in aangeboden afval- en reststoffen. Als gevolg van wijziging van de samenstelling van de referentie voor dierlijke mest hebben dertien stoffen een perspectief voor opname in bijlage Aa indien uitsluitend naar de belasting met zware metalen wordt gekeken. Een aantal van deze stoffen heeft wegens onvoldoende informatie echter een negatief oordeel gekregen. Een aantal van deze stoffen is echter toch in bijlage Aa opgenomen omdat van andere afval- en reststromen van vergelijkbare productieprocessen wel afdoende informatie beschikbaar was waardoor een milieutoets op zware metalen en OM uitgevoerd kon worden en waarbij de milieutoetsen positief werden doorlopen. Deze negatief beoordeelde stoffen konden meeliften met positief beoordeelde stoffen (bv. aardappelstoomschillen).

Tabel 9

Herbeoordeling van stoffen ${ }^{1}$ op basis van zware metalen en arseen

\begin{tabular}{|c|c|c|c|c|c|c|}
\hline \multirow[b]{2}{*}{ Herzien oordeel } & \multicolumn{6}{|c|}{ Oorspronkelijk oordeel } \\
\hline & $\begin{array}{l}\text { Negatief } \\
\text { (voldoende } \\
\text { gegevens) }\end{array}$ & $\begin{array}{l}\text { Negatief } \\
\text { (geen } \\
\text { gegevens) }\end{array}$ & $\begin{array}{l}\text { Negatief } \\
\text { (onvoldoende } \\
\text { gegevens) }\end{array}$ & $\begin{array}{l}\text { Negatief (o.b.v. } \\
\text { beperkte } \\
\text { meetgegevens) }\end{array}$ & Positief & Totaal \\
\hline $\begin{array}{l}\text { Negatief (voldoende } \\
\text { gegevens) }\end{array}$ & 25 & & & & & 25 \\
\hline Negatief (geen gegevens) & & 17 & & & & 17 \\
\hline $\begin{array}{l}\text { Negatief (onvoldoende } \\
\text { gegevens) }\end{array}$ & & & 12 & & & 12 \\
\hline $\begin{array}{l}\text { Negatief (o.b.v. beperkte } \\
\text { meetgegevens) }\end{array}$ & & & & 6 & & 6 \\
\hline Positief & 13 & & & & 50 & 63 \\
\hline Totaal & 38 & 17 & 12 & 6 & 50 & 123 \\
\hline
\end{tabular}

Nadere beschouwing op andere redenen voor afwijzing wees uit dat er een perspectief voor opname in bijlage Aa aanwezig is voor bermgras (een bepaalde partij), (gebleekte) zetmeelvezels (drie verschillende producten), aardappelvoerzetmeel, zilveruien, suikerbietenblad, reststroom die vrijkomt bij het drogen van verse groenten (twee producten), rodekool condenswater en schorseneerschillen en een bijproduct van bij distillatie van glycerine afkomstig van verwerking van plantaardig en dierlijke vetten en oliën tot biodiesel. Inmiddels zijn daarvan de producten aardappelstoomschillen, aardappelpersvezels, aardappelvoerzetmeel, zilveruien, glycerine van plantaardige herkomst in bijlage Aa van de URMW opgenomen. Een reststof bestaande uit gebruikt frituurvet doorstaat weliswaar de milieutoets voor zware metalen, maar gegevens over gehalten aan dioxinen en PCB's blijven ontbreken.

Verschillende analyses van schorseneerschillen leiden tot een onderscheidenlijk resultaat qua milieutoets. Rodekool-condenswater is niet voorzien van afdoende gegevens om tot een oordeelvorming over te gaan. De reststromen van het drogen van groenten kunnen qua milieutoets op zware metalen toegevoegd worden aan bijlage Aa van de URMW. In dit opzicht wordt niet afgeweken van andere restproducten van de groenteverwerkende industrie. Informatie over OM ontbreekt maar dergelijke producten zullen naar huidige beeldvorming geen zorgvragende gehalten bevatten. Informatie over OOM ontbreekt eveneens. Gelet op de al gereguleerde producten met eenzelfde herkomst en bewerkingsprocedé (afgezien van het drogen) en gelet op de bereiding van levensmiddelen, wordt het ontbreken van gegevens niet als belemmerend opgevat. Het bijproduct van biodieselproductie uit dierlijk en plantaardig vet is niet voorzien van afdoende gegevens over de herkomst van het dierlijk vet en over de mate van belasting met organische microverontreinigingen. 


\section{$5 \quad$ Vergelijking met regelgeving in Vlaanderen, Denemarken en Duitsland}

Covergistingsmaterialen worden in Denemarken en Duitsland veel langer toegepast dan in Nederland. De oorzaak ligt in het gegeven dat de Deense en Duitse overheden eerder en gestructureerder (subsidies) de ontwikkeling van biogasinstallaties hetzij op regionale schaal (met name Denemarken ${ }^{56}$ ) hetzij op boerderijschaal (Duitsland ${ }^{57}$ ) stimuleerden. Vlaanderen is bezig met een inhaalslag ${ }^{58}$. Ontwikkelingen rond regelgeving in Denemarken en Duitsland lopen voor op die in Nederland. In Vlaan-deren wordt regelgeving aangepast aan de nieuwste ontwikkelingen. Dit hoofdstuk gaat in op de criteria die gelden in Vlaanderen, Denemarken en Duitsland en een vergelijking met de Nederlandse uitvoering wordt gemaakt. Dit hoofdstuk is als volgt opgebouwd. In paragraaf 5.1 wordt de Vlaamse situatie beschreven; paragrafen 5.2 en 5.3 geven informatie over de regelgeving in Denemarken en Duitsland. De Hoop et al. (2010) hebben voor Vlaanderen en Duitsland de regelgeving beschreven. In dit document wordt die verder uitgewerkt, op basis van de informatie die in 2010-2011 beschikbaar was.

\section{$5.1 \quad$ Vlaanderen}

Bij regelgeving van (co)vergistingsmaterialen als aanvoerstroom (inputstroom) worden onderscheiden:

1. Mest;

2. Producten uit de energieteelt;

3. Secundaire grondstoffen;

4. Organisch Biologisch Afval (OBA) van plantaardige herkomst; en

5. OBA van dierlijke herkomst.

Energieteelt betreft gewassen die speciaal voor de productie van energie worden geteeld. Secundaire grondstoffen zijn organisch biologische afvalstoffen die hernieuwd gebruikt kunnen worden, omdat voldaan wordt aan bepaalde milieuhygiënische bepalingen.

Op deze aanvoerstromen (inputstromen) kunnen het VLAREA ${ }^{59}$ (regionale regelgeving), het Meststoffendecreet (regionale regelgeving), de Transportverordening (Europese regelgeving), het Koninklijk besluit (KB van 7/1/1998, federale regelgeving) en de verordening dierlijke bijproducten van toepassing zijn (EG Verordening 1069/2009).

De van toepassing zijnde regelgeving is ervan afhankelijk of de inputstroom leidt tot een product dat bestemd wordt voor export, voor gebruik op cultuurgrond of voor gebruik op niet-cultuurgrond. Daarnaast wordt bij inputstromen onderscheid aangebracht tussen verwerking van OBA en verwerking van OBA met mest. In Vlaanderen geldt een positieve lijst voor toegelaten covergistingsmaterialen (cosubstraten). Daarbij wordt onderscheid aangebracht tussen inputstromen direct afkomstig van land- en tuinbouw ten opzichte van inputstromen niet afkomstig van de land- en tuinbouw. Inputstromen afkomstig van land- en tuinbouw zijn:

${ }^{56}$ In Denemarken zijn nu 21 gecentraliseerde vergistingsinstallaties(exclusief installaties bij industrie en RWZI) operationeel en circa 60 installaties op boerderijschaal. http://bio-gas-plant.blogspot.com/

${ }^{57}$ In 2010 waren 5.905 installaties in Duitsland in bedrijf. In 2011 zullen naar verwachting 7000 installaties in bedrijf zijn. http://www.biogas.org/

${ }^{58}$ Anno 2011 zijn er 30 installaties in bedrijf, 7 zijn in een bouwfase en en zo'n 20 verkeren in een ontwerp- en vergunningen fase. http://www.biogas-e.be/

${ }^{59}$ In 2012 werd VLAREA vervangen door VLAREMA. De hier in 2011 uitgevoerde toetsing volgt VLAREA. De wijzigingen hebben naar huidige beeldvorming geen gevolgen voor getrokken conclusies. 
- dierlijke mest: excrementen van vee of een mengsel van strooisel en excrementen van vee, alsook producten daarvan;

- land- en tuinbouwproducten van plantaardige oorsprong: gewassen of delen van gewassen geteeld op het land- en tuinbouwbedrijf die niet als afval beschouwd worden.

Andere organische en biologische inputstromen, niet afkomstig van land- en tuinbouw zijn:

- secundaire grondstoffen voor gebruik in of als meststof of bodemverbeterend middel (VLAREA hoofdstuk IV);

- organische en biologische afvalstoffen voorkomend op de positieve lijst (Bijlage 7) mogen verwerkt worden in het agrarisch gebied.

Reststoffen uit de landbouwsector en uit energieteelten mogen zonder verdere regelgeving als covergistingsmateriaal gebruikt worden en tevens mag het eindproduct op het land worden toegepast. Hierbij wordt verwezen naar de "Bioabfallverordnung" (BioAbfV, zie paragraaf 5.3). Daardoor gelden naast samenstellingseisen ook grenzen aan de maximaal toelaatbare dosis. De Vlaamse positieve lijst maakt geen expliciete melding van aanvullende bepalingen, zoals die wel opgenomen zijn in de Duitse positieve lijst. Op deze gebruiksvormen zijn het Mestdecreet, de Transportverordening en de EUVerordening 1069/2009 van toepassing. Indien er een covergistingsmateriaal wordt gebruikt dat in de categorie OBA valt, dan dient er tevens aan bepalingen van het VLAREA voldaan te worden. Zowel OBA als inputmateriaal als ook aan het resulterende digestaat (output) worden dan bepaalde milieuhygiënische samenstellingseisen opgelegd. Elke afvalstof dient te voldoen aan de samenstellingseisen (Tabel 10, Tabel 11). Toepassing van de samenstellingseisen aan een mengsel is niet toegestaan; dit om te voorkomen dat door menging normoverschrijdende afvalproducten worden weggemengd.

\section{Samenstellingseisen van het input- en outputmateriaal}

Tabel 10 geeft de maximumgehalten aan anorganische verontreinigingen (zware metalen en arseen) en maximale giften aan de bodem. Tabel 11 geeft dezelfde informatie voor organische verontreinigingen.

\section{Tabel 10}

Maximumgehalten aan 'anorganische verontreinigende stoffen' en maximale bodemdoseringen als gebruiksvoorwaarden in Vlaanderen.

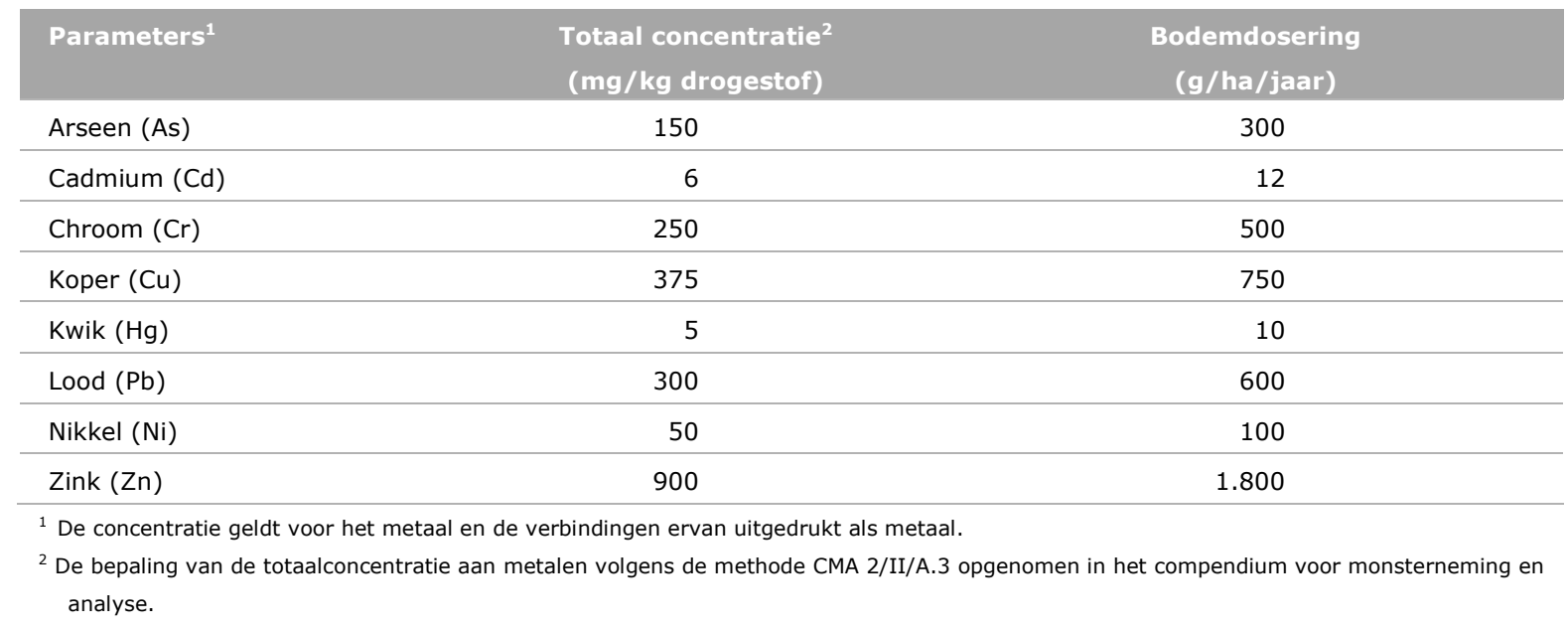

Digestaat van verwerking van OBA al dan niet met dierlijke mest is afval en mag niet in de landbouw worden afgezet tenzij er een ontheffing verleend is van verbodsbepalingen. De systematiek van het verlenen van ontheffingen is vergelijkbaar met die welke tot 1-1-2008 in Nederland gehanteerd werd. Er zijn nu 59 geldige ontheffingen verleend ${ }^{60}$. Een ontheffing wordt niet verleend als er geen keuringsattest afgegeven is.

${ }^{60}$ Dagtekening mei 2011 
Bij gebruik als digestaat mag de dosering niet leiden tot een overschrijding van de maximaal toegelaten vracht aan een anorganische of organische contaminant. VLAREA bijlage 4.2.1.B geeft de maximum toelaatbare bodemdosering (zie Tabellen 10 en 11). Het VLACO controleert aan de hand van audits en monsternames of het digestaat voldoet aan de samenstellingseisen die gelijkwaardig zijn aan die voor het inputmateriaal.

Alleen vergistingsinstallaties die een keuringsattest hebben, kunnen digestaat van afvalstoffen (organische bioafval) als meststof verhandelen. Het keuringsattest wordt in de praktijk afgegeven door VZW VLACO; een gelijkaardige kwaliteitscontrole is ook toegestaan. Vergistingsinstallaties zonder keuringsattest kunnen uitsluitend plantaardige reststoffen verwerken.

Een afvalstof verliest de status van afvalstof indien VLAREA de stof heeft aangewezen als secundaire grondstof. VLAREA bevat een lijst met stoffen die geschikt zijn voor gebruik in de landbouw. Deze lijst omvat onder andere residuen van graanverwerking, groente- en fruitafval van markten, resten van de voedselverwerkende industrie, over-datum-voedsel, resten van zetmeelproductie en organische resten van de productie van alcoholische dranken, frisdrank en vruchtensap. Bijlage 8 geeft deze lijst. De lijst is geïntegreerd met die welke in Duitsland geldt en hanteert de EURAL-codes. Er zijn geen grenzen gesteld wat betreft de mengverhouding van mest en organische afvalstromen. Vergisting van dierlijke bijproducten volgt EU-verordening 1069/2009.

Tabel 11

Maximumgehalten aan organische microverontreinigingen en gebruiksvoorwaarden in Vlaanderen.

\begin{tabular}{llc}
\hline Parameters & $\begin{array}{c}\text { Totalconcentratie }^{3} \\
(\mathbf{m g} / \mathbf{k g} \text { drogestof })\end{array}$ & $\begin{array}{c}\text { Bodemdosering }^{3} \\
\text { (g/ha/jaar) }\end{array}$ \\
\hline Monocyclische aromatische koolwaterstoffen & 1,1 & 2,2 \\
\hline Benzeen & 1,1 & 2,2 \\
\hline Ethylbenzeen & 1,1 & 2,2 \\
\hline Styreen & 1,1 & 2,2 \\
\hline Tolueen & 1,1 & 2,2 \\
\hline Xyleen & & 1,36 \\
\hline Polycyclische aromatische koolwaterstoffen & & 2,2 \\
\hline Benzo(a)antraceen & 0,68 & 2,2 \\
\hline Benzo(a)pyreen & 1,1 & 4,6 \\
\hline Benzo(ghi)peryleen & 1,1 & 4,6 \\
\hline Benzo(b)fluorantheen & 2,3 & 3,4 \\
\hline Benzo(k)fluorantheen & 2,3 & 1,8 \\
\hline Chryseen & 1,7 & 4,6 \\
\hline Fenantreen & 0,9 & 2,2 \\
\hline Fluorantheen & 2,3 & 4,6 \\
\hline Indeno(1,2,3cd)pyreen & 1,1 & 2,3 \\
\hline Naftaleen & & \\
\hline
\end{tabular}

\begin{tabular}{lll}
\hline Overige organische stoffen & & \\
\hline Monochloorbenzeen & 0,23 & 0,46 \\
\hline Dichloorbenzeen & 0,23 & 0,46 \\
\hline Trichloorbenzeen & 0,23 & 0,46 \\
\hline Tetrachloorbenzeen & 0,23 & 0,46 \\
\hline Pentachloorbenzeen & 0,23 & 0,46 \\
\hline Hexachloorbenzeen & 0,23 & 0,46 \\
\hline 1,2-dichloorethaan & 0,23 & 0,46 \\
\hline Dichloormethaan & 0,23 & 0,46 \\
\hline
\end{tabular}




\begin{tabular}{|c|c|c|}
\hline Parameters & $\begin{array}{l}\text { Totaalconcentratie }{ }^{3} \\
\text { (mg/kg drogestof) }\end{array}$ & $\begin{array}{c}\text { Bodemdosering }^{3} \\
\text { (g/ha/jaar) }\end{array}$ \\
\hline Trichloormethaan & 0,23 & 0,46 \\
\hline Tetrachloormethaan & 0,23 & 0,46 \\
\hline Tetrachlooretheen & 0,23 & 0,46 \\
\hline Vinylchloride & 0,23 & 0,46 \\
\hline 1,1,1-trichloorethaan & 0,23 & 0,46 \\
\hline 1,1,2-trichloorethaan & 0,23 & 0,46 \\
\hline 1,1,-dichloorethaan & 0,23 & 0,46 \\
\hline Cis+trans-1,2-dichloorethaan & 0,23 & 0,46 \\
\hline Hexaan & 5,5 & 11 \\
\hline Heptaan & 5,5 & 11 \\
\hline Octaan & 5,5 & 11 \\
\hline $\begin{array}{l}\text { Extraheerbare } \\
\text { organohalogeenverbindingen(EOX) }\end{array}$ & \multicolumn{2}{|c|}{ organohalogeenverbindingen(EOX) } \\
\hline Minerale olie & 560 & 1120 \\
\hline \multicolumn{3}{|l|}{$\left(\mathrm{PCB}\right.$ als som 7 congeneren $\left.{ }^{4}\right)$} \\
\hline $\begin{array}{l}3 \text { Bepaling van de totaalconcentratie aan } \\
\text { monsterneming en analyse. } \\
{ }^{4} \text { Deze } 7 \text { congeneren zijn identiek aan die }\end{array}$ & $\begin{array}{l}\text { olgens de methode opgenor } \\
18,138,153 \text { en } 180) \text {. }\end{array}$ & het compendium voor \\
\hline
\end{tabular}

\subsection{Denemarken}

Denemarken kent zowel een sturing van de milieuhygiënische kwaliteit op input (covergistingsmaterialen) als op output (digestaat).

Een overzicht van de Deense regelgeving voor covergistingsmaterialen werd eerder gegeven door Tijmensen et al. (2003). In 2006 is de Deense regelgeving aangepast vanwege het opheffen van de provincies waardoor gemeenten de uitvoering van toelating van covergistingsmaterialen zijn gaan uitvoeren (VEJ nr. 9473 af 25/08/2010 ${ }^{61}$ ), alsmede de controle daarop. De aanpassing heeft ook geleid tot wijzigingen bij het gebruik van afval voor agrarische doeleinden ${ }^{62}$. Het gebruik van afvalstoffen voor agrarische doeleinden wordt nu geregeld door BEK nr. $1650^{63}$. In Denemarken is een aparte en samenhangende regelgeving van kracht voor het gebruik van afval voor agrarische doeleinden. Covergistingsmaterialen zijn hiervan een onderdeel.

Onderscheid wordt gemaakt tussen mest en digestaat. Indien het aandeel afvalstoffen voor vergisting maximaal $25 \%$ van de drogestof van het rantsoen uitmaakt, dan is het resulterende digestaat mest en valt de stof onder de bepalingen die gelden voor mest. Is het aandeel groter, dan wordt het digestaat aangemerkt als afval waarvoor gebruiksnormen gelden voor stikstof (170 kg N/ha), fosfaat (30 kg $\mathrm{P} /$ ha), kalium $\left(^{64}\right)$, zwavel (i), ijzer (i), mangaan (i) en zink (i) en maximale doseringen aan drogestof per ha per jaar ( 7 ton drogestof/ha/jaar ${ }^{65}$ ). Het gebruik van afval mag niet leiden tot een overdosering van een van de genoemde waardegevende bestanddelen. Het waardegevende bestanddeel dat het eerste de gebruiksnorm bereikt bepaalt de dosering van afval bij agrarisch gebruik. Op het gebruik

\footnotetext{
${ }^{61}$ VEJ nr 9473 af 25/08/2010 - Gældende Vejledning fra Miljøstyrelsen Anvendelse af affald til jordbrugsformål. Richtlijn van het Environmental Protection Agency (Miljøminsteriet, Miljøstylrelsen). Gebruik van afvalstoffen voor agrarische doeleinden.

${ }^{62}$ Tot dan toe gold: Miljø-og Energiministeriet (2000): "Bekendtgørelse om anvendelse af affaldsprodukter til jordbrugsformål" (Slambekendtgørelsen). BEK nr. 49 af 20/01/2000.

https://www.retsinformation.dk/Forms/R0710.aspx?id=20975 (link inmiddels opgeheven).

${ }^{63}$ BEK nr 1650 af 13/12/2006 Gældende (Slambekendtgørelsen) Offentliggørelsesdato: 23-12-2006, Miljøministeriet.

${ }^{64}$ Afhankelijk van de behoefte van het gewas. Het bemestingsplan dient deze behoefte te verantwoorden.

${ }^{65}$ Gemiddeld over een periode van 10 jaar, voor bossen en parken mag gemiddeld over deze periode 15 ton drogestof/ha/jaar gebruikt worden.
} 
houdt de gemeente toezicht. Het gebruik van afval wordt gereguleerd met een vergunningenstelsel. Er is een lijst van afvalstoffen aangewezen die zonder voorafgaande toestemming gebruikt kunnen worden mits voldaan wordt aan de regels van het besluit BEK nr. 1650. Deze lijst ${ }^{66}$ omvat 6 categorieën (respectievelijk $A$ tot en met $F$ ).

A. Slib en afvalwater en verontreinigd restproduct van de verwerking van plantaardige grondstoffen en slib en afvalwater van zuivelfabrieken.

B. Slib uit viskwekerijen:

- Slib van zoetwatervis boerderijen en riool-en afvalwater van recirculatiesystemen voor het kweken van vis.

- Slib uit vijvers.

C. Slib afkomstig van de verwerking van dierlijke grondstoffen:

- Slib en flotatievet van vetvangers uit afvalwater van slachthuizen en uitbeenderijen, verzameld nadat het afvalwater eerst een primaire behandeling heeft ondergaan volgens de dierlijke bijproducten verordening.

- Slib en flotatievet van vetvangers uit afvalwater van levensmiddelenbedrijven anders dan slachthuizen en uitbeenderijen.

- Slib en flotatievet van vetvangers uit afvalwater van visverwerkende industrieën.

D. Organisch afval:

- GFT-afval.

- Voedselresten van catering ingezameld als GFT-afval.

- Afval van voedsel uit winkels die niet vallen onder F).

E. Zuiveringsslib:

- Slib uit huishoudelijk afvalwater installaties.

- Slib uit de particuliere verwerkingsinstallaties voor de behandeling van huishoudelijk afvalwater.

F. Dierlijke bijproducten, zoals gedefinieerd in het Europees Parlement en de Raad Verordening (EG) nr. 1774/2002 ${ }^{67}$ gezondheidsvoorschriften inzake dierlijke bijproducten niet bestemd voor menselijke consumptie, met uitzondering van organisch afval en etensresten van de catering. Afvalstoffen, waaronder covergistingsmaterialen, dienen altijd te voldoen aan de volgende samenstellingseisen voor zware metalen en arseen en aangewezen organische microverontreinigingen. Daarnaast mogen afvalstoffen geen andere milieubelastende stoffen ${ }^{68}$ bevatten in significante hoeveelheden. De gemeente bepaalt welke (andere) contaminanten betrokken dienen te worden bij de registratie en verwerking van afvalstoffen die bestemd worden voor landbouwkundige toepassingen (hieronder begrepen covergistingsmaterialen). Bijlage 3 van het BEK nr. 1650 van 13/12/2006 geeft de volgende Tabellen met samenstellingseisen voor zware metalen, arseen en organische microverontreinigingen (Tabellen 12, 13 en 14).

\section{Tabel 12}

Grenswaarden voor zware metalen in de drogestof of herleid op totaal fosfor.

\begin{tabular}{lcc} 
Zwaar metaal & mg per dag $\mathrm{kg}$ drogestof & mg per kg totaal fosfor \\
\hline Cadmium & 0,8 & 100 \\
\hline Kwik & 0,8 & 200 \\
\hline Lood $^{1)}$ & 120 & 10.000 \\
\hline Nikkel & 30 & 2.500 \\
\hline
\end{tabular}

1) Grenswaarde lood is $60 \mathrm{mg}$ per $\mathrm{kg}$ drogestof of $5.000 \mathrm{mg}$ per $\mathrm{kg}$ totaal fosfor voor gebruik in particuliere tuinen. Voor gebruik in particuliere tuinen geldt ook voor arseen een waarde van $25 \mathrm{mg}$ per $\mathrm{kg}$ drogestof.

\footnotetext{
${ }^{66}$ Dit betreft een officieuze vertaling uit het Deens, alleen de Deense versie heeft rechtsgeldigheid.

${ }^{67}$ Thans vervangen door EU Verordening 1069/2009.

${ }^{68}$ LOUS 2009: Listen over uønskede stoffer 2009. Orientering fra Miljøstyrelsen Nr. 32010.
} 
Tabel 13

Grenswaarden voor zware metalen herleid op de drogestof.

\begin{tabular}{lc} 
Zwaar metaal & mg per kg drogestof \\
Chroom & 100 \\
\hline Zink & 4.000 \\
\hline Koper & 1.000 \\
\hline
\end{tabular}

De producent van afval kan ervoor kiezen om grenswaarden in de drogestof dan wel herleid op kg fosfor te hanteren. Bij zware metalen en arseen moeten de analyseresultaten van de laatste vijf monsters tenminste $75 \%$ lagere gehalten hebben dan de door regelgeving opgelegde grenswaarden. Een monster mag echter nooit een analyseresultaat hebben dat een grenswaarde met meer dan $50 \%$ overschrijdt. Als een monster een drempel overschrijdt met 0 tot $50 \%$ moet onmiddellijk opnieuw worden bemonsterd en geanalyseerd.

\section{Tabel 14}

Grenswaarden voor organische microverontreinigingen (xenobiotica).

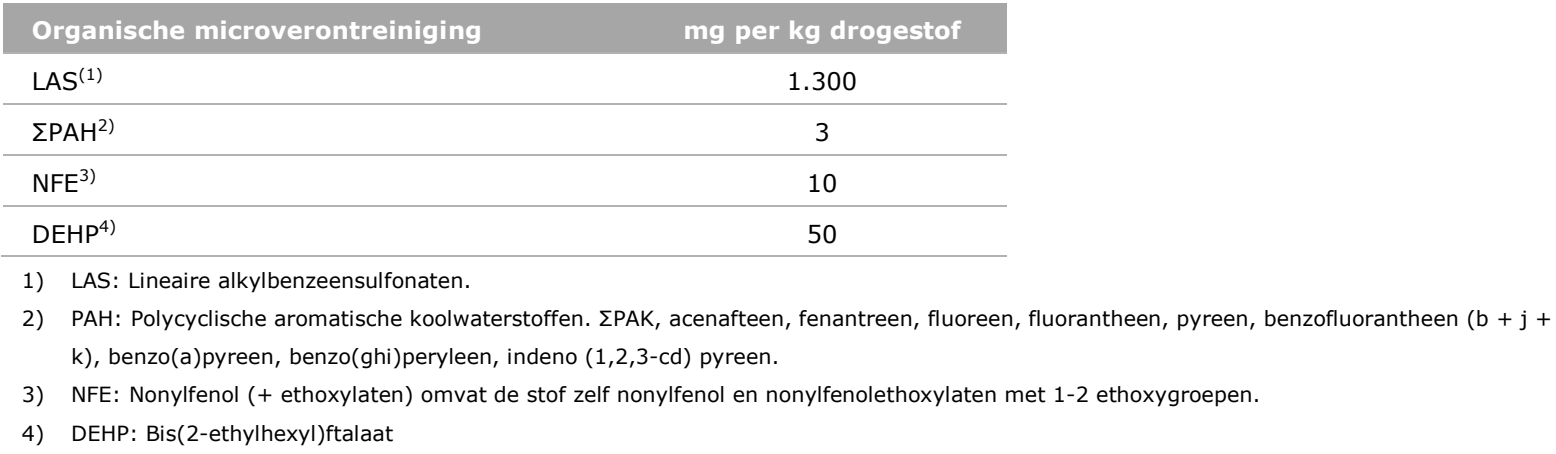

Elk individueel analyseresultaat van een organische microverontreiniging moet voldoen aan de grenswaarden in Tabel 14. Tabel 15 geeft de voorschriften bij landbouwkundige toepassingen van afval.

De Deense regelgeving stelt scherpe criteria aan sanitatie van afvalstoffen, waaronder covergistingsmaterialen, die gebruikt worden in de landbouw. Voor de zes categorieën $A$ tot en met $F$ gelden de volgende bepalingen inzake hygiënisatie (sanitatie)-voorschriften (Tabel 16).

Niet verwerkte stoffen (of niet behandelde) zijn stoffen die geen stabilisatie, gecontroleerde compostering en/of gecontroleerde hygiënisatie (sanitatie) hebben ondergaan.

Bij stabilisatie zijn vijf processen aangewezen en als aanvullend criterium dient een gestabiliseerde afvalstof geen stankoverlast te veroorzaken. De vijf processen zijn:

A. Anaërobe stabilisatie door vergisting in een verwarmde vergistingstank of biogasreactor.

B. Aërobe stabilisatie door beluchting van slib, hetzij in een speciaal geconstrueerde beluchtings-tank voor slib hetzij langdurig in een actiefslibinstallatie.

C. Composteren waarbij de temperatuur gecontroleerd wordt.

D. Chemische stabilisatie door toevoeging van kalk.

E. Slib dat in een installatie een biologische afbraak gedurende tenminste 6 maanden heeft ondergaan gerekend vanaf het tijdstip waarop de laatste vracht afval werd toegevoegd.

Indien digestaat aangemerkt wordt als dierlijke mest, dan gelden alle bepalingen voor dierlijke mest. Betreft het digestaat afval, dan zal altijd informatie over de gehalten aan zware metalen en arseen en organische microverontreinigingen in het digestaat gegeven moeten worden.

Gecontroleerde compostering is compostering waarbij dagelijks de temperatuur wordt gemeten en alle afvalstoffen gedurende twee weken minimaal bij een temperatuur van $55^{\circ} \mathrm{C}$ verblijven. De behandeling moet gedocumenteerd worden met de meting van de temperatuur. 
Tabel 15

Voorschriften bij landbouwkundige toepassingen van afval.

\begin{tabular}{|c|c|c|c|c|}
\hline \multirow[t]{2}{*}{ Categorie afval } & \multicolumn{4}{|l|}{ Behandeling afval } \\
\hline & Niet verwerkt & Gestabiliseerd & $\begin{array}{l}\text { Gecontroleerde } \\
\text { compostering }\end{array}$ & $\begin{array}{l}\text { Gecontroleerde } \\
\text { hygiënisatie } \\
\text { (sanitatie) }\end{array}$ \\
\hline $\begin{array}{l}\text { A) Slib en afvalwater en } \\
\text { verontreinigde reststoffen van } \\
\text { de verwerking van plantaardige } \\
\text { grondstoffen en slib en } \\
\text { afvalwater van zuiverfabrieken. }\end{array}$ & + & + & + & + \\
\hline B) Slib van viskwekerijen & $\begin{array}{l}\text { Niet van } \\
\text { toepassing op } \\
\text { recreatiegebieden } \\
\text { en binnenlandse } \\
\text { tuinieren }\end{array}$ & + & + & + \\
\hline $\begin{array}{l}\text { C) Slib van verwerking van } \\
\text { dierlijke grondstoffen }\end{array}$ & - & - & - & $+(3)$ \\
\hline D) Organische afval & - & - & $(1)+(4)$ & $+(4)$ \\
\hline E) Zuiveringsslib & - & $\begin{array}{l}\text { Niet gebruiken bij } \\
\text { voedselgewassen, } \\
\text { recreatiegebieden } \\
\text { en eigen tuin. } \\
\text { Binnen } 6 \text { uur na } \\
\text { uitrijden } \\
\text { onderwerken. (2) }\end{array}$ & $\begin{array}{l}\text { Niet gebruiken bij } \\
\text { voedselgewassen, } \\
\text { recreatiegebieden } \\
\text { en eigen tuin. (2) }\end{array}$ & + \\
\hline
\end{tabular}

F) Dierlijke producten, met uitzondering van gemeentelijk organische afval en afval van grootkeukens
Verordening (EG) nr. 1069/2009 van 21 oktober 2009 tot vaststelling van gezondheidsvoorschriften inzake dierlijke bijproducten niet bestemd voor menselijke consumptie

- Niet gebruiken voor agrarische doeleinden.

+ Kan op basis van hygiënische overwegingen zonder beperkingen gebruikt worden.

(1) Bij gebruik van hoefdieren, verspreiding en inwerken van de compost wordt uitgevoerd vóór de inzaai.

(2) In de gebieden met toediening van zuiveringsslib kan tot 1 jaar na de injectie alleen maar graan, zaad voor graan, grassen of vergelijkbare gewassen voor de industriële vervaardiging van droogvoer geteeld worden. Voedselgewassen mogen niet geteeld worden, dit zijn bv. aardappelen, gras, snijmaïs, voederbieten en suikerbieten. Door het verspreiden van zuiveringsslib in het bos moet het bos gesloten blijven voor het publiek tot tenminste 1/2 jaar na de toediening. Afscherming van het gebied moet worden uitgevoerd met borden die het plukken van bessen, paddenstoelen en dergelijke verbieden. Opslagtanks, vervoersmiddelen, verspreidings- en de injectieapparatuur moet onmiddellijk na gebruik gereinigd worden.

(3) Pas na reiniging op $70^{\circ} \mathrm{C}$ gedurende 60 minuten en de daaropvolgende vergisting of compostering.

(4) Voor gebruik op grasland, zijn de regels opgenomen die in het Europees Parlement zijn aangenomen en is Verordening (EG) nr. 1069/2009 van 21 oktober 2009 tot vaststelling van gezondheidsvoorschriften inzake dierlijke bijproducten niet bestemd voor menselijke consumptie, ook gevolgd.

Gecontroleerde hygiënisatie (sanitatie) onder gaat een van de onder $a$, b of c genoemde behandelingsvormen en tevens voldoet het resulterende gehygiëniseerde afval aan de volgende criteria:

- Salmonella kan niet worden gedetecteerd;

- Coli is lager dan $100 \mathrm{CFU}^{69} / \mathrm{g}$ product (nat gewicht);

- Enterokokken zijn lager dan $100 \mathrm{CFU/g}$ product (nat gewicht).

Indien digestaat aangemerkt wordt als dierlijke mest, dan gelden alle bepalingen voor dierlijke mest. Betreft het digestaat afval, dan zal altijd informatie over de gehalten aan drogestof, nutriënten, zware metalen en arseen en organische microverontreinigingen in het digestaat gegeven moeten worden en dienen pathogenen en fysische verontreinigingen (glas etc.) te ontbreken.

${ }^{69}$ CFU: kolonie-vormende eenheden 
Tabel 16

Behandelingstypen

\begin{tabular}{|c|c|c|c|c|}
\hline \multicolumn{2}{|c|}{ Temperatuur } & \multirow[t]{2}{*}{$\begin{array}{l}\text { Verblijf tijd door de vergisting in } \\
\text { thermofiel (1) reactorvat }\end{array}$} & \multicolumn{2}{|c|}{$\begin{array}{l}\text { Verblijftijd van de behandeling in de afzonderlijke } \\
\qquad \text { sanitatietank (2) }\end{array}$} \\
\hline & & & $\begin{array}{c}\text { vóór of na vergisting in } \\
\text { thermofiel reactorvat } \\
\text { (3) }\end{array}$ & $\begin{array}{l}\text { vóór of na mesofiele } \\
\text { vergisting in reactorvat } \\
\text { (4) }\end{array}$ \\
\hline \multicolumn{2}{|c|}{ Graden Celsius } & Duur, uren & Duur, uren & Duur, uren \\
\hline \multicolumn{2}{|c|}{52,0} & 10 & & \\
\hline \multicolumn{2}{|c|}{53,5} & 8 & & \\
\hline \multicolumn{2}{|c|}{55,0} & 6 & 5,5 & 7,5 \\
\hline \multicolumn{2}{|c|}{60,0} & & 2,5 & 3,5 \\
\hline \multicolumn{2}{|c|}{65,0} & & 1,0 & 1,5 \\
\hline 1) & \multicolumn{4}{|c|}{$\begin{array}{l}\text { Onder thermofiele vergisting wordt in deze context de vergisting bij } 52^{\circ} \mathrm{C} \text { of hoger bedoeld. Gegarandeerde minimale tijd in bedrijf reactor } \\
\text { tank (MGRT) worden gegeven in uren. Verondersteld ook dat de verblijftijd in het reactorvat tenminste } 7 \text { dagen is. }\end{array}$} \\
\hline 2) & \multicolumn{4}{|c|}{$\begin{array}{l}\text { De gecontroleerde hygiënisatie vindt plaats in aparte sanitatietank in een thermofiele of mesofiele biogas-reactor. Vergisting vindt plaats } \\
\text { voor of na de sanitatie. Gegarandeerde minimale tijd in bedrijf zijnde sanitatietank wordt gegeven in uren. }\end{array}$} \\
\hline 3) & \multicolumn{4}{|c|}{$\begin{array}{l}\text { Onder thermofiele vergisting wordt in deze context de vergisting bij } 52^{\circ} \mathrm{C} \text { of hoger bedoeld. Veronderstel wordt dat ook de retentietijd in het } \\
\text { reactorvat tenminste } 7 \text { dagen is. }\end{array}$} \\
\hline 4) & \multicolumn{4}{|c|}{$\begin{array}{l}\text { Onder mesofiele vergisting wordt in deze context de vergisting bij een temperatuur tussen } 20^{\circ} \mathrm{C} \text { en } 52^{\circ} \mathrm{C} \text { bedoeld. Eveneens wordt } \\
\text { aangenomen dat de verblifttijd in het reactorvat tenminste } 14 \text { dagen is. }\end{array}$} \\
\hline
\end{tabular}

\subsection{Duitsland}

De regelgeving die in Duitsland van toepassing is op vergisting van mest en covergistingsmaterialen is beschreven door De Hoop et al. (2010). Er zijn drie wetten en vijf verordeningen van kracht (De Hoop et al., 2010). In deze paragraaf wordt nader ingegaan op toegelaten covergistingsmaterialen en de samenstellingseisen die gesteld worden aan deze materialen. Het gebruik van afvalstoffen als covergistingsmateriaal wordt in het bijzonder gereguleerd door de Verordnung über das Inverkehrbringen von Düngemitteln, Bodenhilfsstoffen, Kultursubstraten und Pflanzenhilfsmitteln (Düngemittelverordnung - DüMV ${ }^{70}$ ) en de Bioabfallverordnung (BioAbfV) ${ }^{71}$. Naast deze regelgeving wordt ook een 'positieve lijst' gehanteerd bij vergoedingen voor groene energie. Deze lijst benoemt zuiver plantaardige reststromen met hun bijdrage aan de energieproductie ( $k W h_{e l}$ per ton product) ten behoeve van de NawaRo-bonus ${ }^{72}$. Deze lijst wordt in de Duitse praktijk de 'positieve lijst' genoemd maar heeft geen rechtsgeldigheid ${ }^{73}$.

Het gebruik van plantenresten van het eigen landbouwbedrijf als covergistingsmaterialen ressorteert niet onder BioAbfV en wordt vrij toegelaten.

Het gebruik van digestaat ressorteert onder DüMV. DüMV wijst stoffen aan die een anaërobe behandeling mogen ondergaan. De aanwijzing is afgestemd op BioAbfV. Beide verordeningen leggen generieke eisen op aan maximaal toelaatbare gehalten aan contaminanten als output of als input (Tabel 17).

Tabel 17 geeft een minimumlijst van contaminanten. Het aantal contaminanten waarop onderzocht dient te worden, kan worden uitgebreid indien daar aanleiding voor is. Daarnaast gelden generieke bepalingen bij gebruik van bioafval als meststof waaronder restproducten van vergisting. Die gelden in het bijzonder bescherming ter voorkoming van de overdracht van voor mens, dier of gewas pathogene (micro)organismen.

- Er mag geen Salmonella in het materiaal worden aangetroffen (in $50 \mathrm{~g}$ monster). Indien Salmonella is aangetroffen gelden specifieke bepalingen voor landbouwkundige toepassing t.a.v.

\footnotetext{
${ }^{70}$ http://www.lanuv.nrw.de/agrar/duengemittel/duengemittelgesetz.htm

${ }^{71}$ http://www.gesetze-im-internet.de/bundesrecht/bioabfv/gesamt.pdf

${ }^{72}$ NawaRo: Nachwachsende Rohstoffen.

${ }^{73}$ http://www.biogas.org/edcom/webfvb.nsf/ID/DE_Homepage
} 
in het handelsverkeer brengen, onderwerkplicht op bouwland, inscharen vee op grasland, verbod uitrijden in een drinkwaterbeschermingsgebied).

- In plantaardige reststoffen of grondstoffen mogen geen plantpathogene (micro)-organismen en/of virussen aanwezig zijn.

\section{Tabel 17}

Maximaal toelaatbare gehalten aan contaminanten bij toepassing als meststof (DüMV) of bij gebruik als bioafval (BioAbfV) in $\mathrm{mg}$ per $\mathrm{kg}$ drogestof.

\begin{tabular}{|c|c|c|}
\hline Contaminant & $\begin{array}{l}\text { DüMV } \\
\text { output }\end{array}$ & $\begin{array}{c}\text { BioAbfV } \\
\text { input }\end{array}$ \\
\hline $\mathrm{Pb}$ & 150 & 150 \\
\hline $\mathrm{Cd}$ & 1,5 & 1,5 \\
\hline $\mathrm{Cr}$ & - & 100 \\
\hline $\mathrm{Cu}$ & - & 100 \\
\hline $\mathrm{Ni}$ & 80 & 50 \\
\hline $\mathrm{Hg}$ & 1,0 & 1,0 \\
\hline $\mathrm{Zn}$ & - & 400 \\
\hline As & 40 & - \\
\hline TI & 1,0 & - \\
\hline $\mathrm{Cr}^{\mathrm{IV}}$ & 2,0 & - \\
\hline Som van PFOS en PFOA. & 0,1 & - \\
\hline PFOS: geperfluoreerd octaansulfonaat & & \\
\hline PFOA: geperfluoreerd octaanzuur & & \\
\hline
\end{tabular}

Deze beschermingsmaatregelen zijn uitgewerkt in directe controles op het proces (bv. telling van Salmonella), indirecte controles (bv. op procesparameters als temperatuur, duur vergistingsproces) en controle op de hygiënische kwaliteit van het eindproduct van een bewerking (bij vergisting het digestaat) ${ }^{74}$.

DüMV legt ook bepalingen op aan hulpstoffen, bijvoorbeeld coagulatie- en flotatiemiddelen. Vanaf 2013 worden uitsluitend coagulatie- en vlokmiddelen toegestaan die volledig biologisch afbreekbaar zijn.

DüMV schrijft voor waaraan een als meststof te gebruiken digestaat dient te voldoen:

- Melding van typeaanduiding, bodemhulpstof, substraat, plantenhulpstof conform voorschriften.

- Opgave van waardegevende bestanddelen met hun gehalten.

- Opgave van de gebruikte uitgangsstoffen (mest en covergistingsmaterialen).

- Opgave van beschikbaarheid van nutriënten.

- Aandeel niet biologisch afbreekbare (vreemde) delen.

- Aanwijzingen voor opslag en gebruik.

- Aanwijzingen in geval gebruik beperkt is door een omstandigheid (bv. de aanwezigheid van Salmonella).

Afvalstoffen (bioafval) die als covergistingsmateriaal toegepast mogen worden staan in bijlage 8. België volgt eenzelfde systematiek. De Duitse regelgeving hanteert de Euralcode die als toevoeging wordt gegeven bij een begripsomschrijving voor afval. De begripsomschrijvingen tussen de Duitse en de Belgische lijst bij eenzelfde Euralcode verschillen enigszins maar niet wezenlijk ${ }^{75}$. Afvalstoffen die niet in de bijlage staan, mogen niet worden toegepast, tenzij de daartoe bevoegde instanties daarvoor vergunning hebben verleend (De Hoop et al., 2010). De bijlage voorziet in aanvullende bepalingen voor landgebruik (grasland, bouwland, bosbouw), onderwerkplicht en (vreemde) materialen die bij opname door dieren tot leed/schade leiden. Stoffen van bioafval mogen niet samen met zuiveringsslib

\footnotetext{
74 §5 DüMV, Tabel 1 van BioAbfV.

${ }^{75}$ Bv. Bij 020106 geeft de Duitse lijst 'Tierische Ausschiedungen, Gülle/Jauche und Stallmist (einschliesslich vordorbenes Stroh), Abwässer, getrennt gesammelt und extern behandelt'. De Belgische lijst meldt Dierlijke faeces, urine en mest (inclusief gebruikt stro), afvalwater, gescheiden ingezameld en elders verwerkt.
} 
worden toegepast. Bioafval kan worden toegepast mits de ontvangende bodem wordt bemonsterd en vastgesteld is dat de gehalten aan zware metalen niet de opgelegde maximale grenzen overschrijden (Tabel 18). Dit is vergelijkbaar met de in Nederland geldende regels voor gebruik van zuiveringsslib. De verplichting vervalt indien het bioafval gecontroleerd wordt door een daartoe gecertificeerde organisatie. Bij permanent grasland vervalt de verplichting voor bemonstering van de bodem indien het bioafval daarvoor toegelaten is (kolom 3 Bijlage 8).

Tabel 18

Maximale samenstellingseisen voor grond warop bioafval wordt toegepast in $\mathrm{mg}$ per $\mathrm{kg}$ drogestof.

\begin{tabular}{llllllll} 
Grondsoort & Cd & $\mathrm{Pb}$ & $\mathrm{Cr}$ & $\mathrm{Cu}$ & $\mathrm{Hg}$ & $\mathrm{Ni}$ & \\
Klei (1) & 1,5 & 100 & 100 & 60 & 1 & 70 & 200 \\
\hline Leem (2) & 1 & 70 & 60 & 40 & 0,5 & 50 & 150 \\
\hline Zand & 0,4 & 40 & 30 & 20 & 0,1 & 15 & 60 \\
\hline
\end{tabular}

1) $\mathrm{Bij} \mathrm{pH}<6$ gelden de maximale waarden voor $\mathrm{Cd}$ en $\mathrm{Zn}$ van leem

2) $\mathrm{Bij} \mathrm{pH}<6$ gelden de maximale waarden voor $\mathrm{Cd}$ en $\mathrm{Zn}$ van zand.

Aangewezen stoffen mogen zonder vooronderzoek toegepast worden indien op grond van hun aard, eigenschappen en herkomst verwacht kan worden dat aan eisen voor sanitatie en contaminatie voldaan zal worden (kolom 3 Bijlage 8 ). Dit vraagt toestemming en instemming van de aangewezen autoriteit (ontheffing van het geldende verbod).

\subsection{Toetsing aan Vlaamse, Deense en Duitse milieucriteria}

Toetsing aan buitenlandse regelgeving is mogelijk als de gehalten aan verontreinigende stoffen bekend zijn van de (afval)stof die als meststof, bodemverbeteraar of covergistingsmateriaal wordt bestemd. Het gegeven dat meetgegevens van de in hoofdstuk 4 besproken stoffen veelal ontbreken, betekent dat geen van die stoffen beantwoord aan de reguliere vereisten van Vlaanderen, Denemarken en Duitsland. Slechts voor een beperkt aantal stoffen is adequate informatie aangeleverd. Informatie over tenminste $\mathrm{N}$ en $\mathrm{P}$ en contaminanten door de regelgeving aangewezen, dient beschikbaar te zijn. Door het ontbreken van deze meetgegevens bij veel van de in hoofdstuk 4 besproken stoffen is gebruik ervan niet toegestaan.

De bijeengebrachte gegevens zijn vergeleken met de samenstellingseisen die gelden in Vlaanderen, Denemarken en Duitsland.

Bij Vlaanderen geldt een maximum dosering aan een verontreinigende stof. Dat maximum is in deze studie vertaald naar de maximale dosering gegeven de maximaal toelaatbare vracht. Indien deze dosering hoger is dan 10 ton/ha/jaar, dan doorstaat de stof de toets. Dit betreft een omzetting naar stap 2 van het protocol dat in Nederland wordt gevolgd. In Vlaanderen geldt die stap niet, ook lagere doseringen worden geaccepteerd.

In Denemarken geldt een criterium voor bijmenging van een covergistingsmateriaal met dierlijke mest. Beneden een bepaald percentage geldt het digestaat als dierlijke mest, daarboven gelden regels voor toepassing van digestaat (maxima aan drogestof en nutriënten, zie paragraaf 5.2). Per stof wordt in Tabel 19 dit maximum gegeven. Al bij lage bijmengpercentages (herleid op de drogestof) verliest het digestaat de rechtspositie van dierlijke mest (Tabel 19). Natte producten kunnen met een groter percentage worden bijgemengd maar droge producten kunnen hooguit met enkele procenten worden bijgemengd zonder de status van dierlijke mest te verliezen.

Voor arseen is het criterium gehanteerd dat geldt voor de particuliere tuin, voor cultuurland geldt (nog) geen samenstellingsnorm.

Indien gespiegeld wordt aan de maximale samenstellingseisen voor zware metalen en arseen herleid op de drogestof, dan doorstaan de stoffen van deze studie de milieucriteria van Vlaanderen, Denemarken en Duitsland. Voorzover gegevens beschikbaar zijn, doorstaan de stoffen ook de Vlaamse criteria voor gehalten aan OM. 
Verschillen treden op wanneer criteria voor maximale vracht aan zware metalen en arseen getoetst worden aan die gebaseerd op het gebruik als stikstof- of fosfaatmeststof (Vlaanderen) of herleid worden op kg fosfor (Denemarken). Bij toetsing van de vracht bij gebruik als stikstof-en fosfaatmeststof zijn de in Nederland geldende criteria gebruikt namelijk $250 \mathrm{~kg} \mathrm{~N} / \mathrm{ha}$ en $90 \mathrm{~kg}$ $\mathrm{P}_{2} \mathrm{O}_{5} /$ ha. Vlaanderen limiteert het gebruik op vracht, de gift aan stikstof of fosfaat volgt.

In Denemarken kan gekozen worden tussen toetsing op basis van gehalten in de drogestof of herleid op fosfor. Omdat de criteria op basis van gehalten in de drogestof bij de onderhavige stoffen niet tot normoverschrijding leiden, zal voor de laatst genoemde criteria gekozen worden. Tabel 19 vat de resultaten van de toetsing samen.

Gegevens van Tabel 19 zijn een onderdeel van de toetsing of toepassing van stoffen als covergistingsmateriaal toelaatbaar is. De vergisting van deze stoffen is in Vlaanderen, Denemarken en Duitsland ingebed in regelgeving die ook stuurt op de bedrijfsvoering (keuringsattest in Vlaanderen), toelaatbaarheid van een reststof (ontheffing van verbodsbepalingen in Vlaanderen, toestemming van gemeente in Denemarken, goedkeuring door Duitse deelstaten) en op output (digestaat dient in alle landen te voldoen aan samenstellingseisen). In Vlaanderen wordt expliciet gestuurd op de maximaal toelaatbare vracht van verontreinigende stoffen; in Denemarken impliciet via samenstellingseisen en maxima aan dosering. Giften aan stikstof, fosfor en kalium mogen niet hoger zijn dan die het gewas nodig heeft. De gift aan stikstof mag niet hoger zijn dan $170 \mathrm{~kg} \mathrm{~N} / \mathrm{ha} / \mathrm{jaar}$ en fosfor niet hoger dan 30

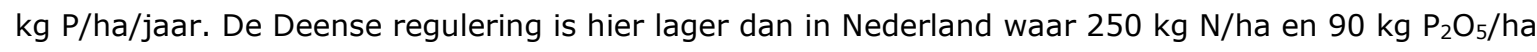
(39 kg P/ha) de vracht bepalen. De vracht aan verontreinigende stoffen wordt door - wat - hogere toegelaten gehalten aan verontreinigende stoffen in Denemarken gereguleerd door lagere doseringen aan $\mathrm{N}$ en $\mathrm{P}$. In Duitsland is in de praktijk het aandeel covergistingsmateriaal in het rantsoen beperkt. Meestal wordt snijmaïs (ingekuild) en gras gebruikt. Het aandeel overige covergistingsmaterialen in het rantsoen is zelden hoger dan $25 \%$, vaak lager (enige procenten).

Sanitatie vraagt bijzondere aandacht bij vergisting van (bioafval)stoffen in Vlaanderen, Denemarken en Duitsland. Ter voorkoming van risico's van verspreiding van pathogene microörganismen voor mens, dier en gewas gelden strikte sanitatie-eisen. Dit aspect is niet opgenomen in Tabel 18, de geldende eisen zijn beschreven in voorafgaande paragrafen.

\section{Tabel 19}

Oordeel na toetsing aan Vlaamse criteria gebaseerd of stikstof- en fosfaatgift en Deense criterium voor onderscheid tussen dierlijke mest en digestaat en oordeel na toetsing aan het Deense milieucriterium bij herleiding op fosfor.

\begin{tabular}{|c|c|c|c|c|c|c|}
\hline \multirow[t]{3}{*}{$\mathrm{Nr}$} & \multirow[t]{3}{*}{ Stof } & \multirow{3}{*}{$\begin{array}{l}\text { Ontbrekend } \\
\text { gegeven }\end{array}$} & \multicolumn{2}{|l|}{ België } & \multicolumn{2}{|c|}{ Denemarken } \\
\hline & & & Vracht & & & \\
\hline & & & $N$-gift & fosfaatgift & $\begin{array}{l}\text { dierlijke } \\
\text { mest, \% }\end{array}$ & $Z M$ op $P$ \\
\hline \multirow[t]{2}{*}{1} & Zonnebloempitten - zaden & As & ja & ja & 3 & ja \\
\hline & Geëxtraheerd zonnebloemmeel & $\mathrm{Cr}, \mathrm{Ni}, \mathrm{As}$ & ja & ja & 3 & ja \\
\hline \multirow[t]{9}{*}{2} & Bermmaaisel Borculo & & neen & ja & 5 & neen \\
\hline & Bermmaaisel Eibergen & & ja & ja & 6 & neen \\
\hline & Bermmaaisel Apeldoorn & & neen & neen & 8 & neen \\
\hline & Bermmaaisel Regge \& Dinkel & & neen & neen & 5 & neen \\
\hline & Bermmaaisel Dinkelland & & neen & ja & 6 & neen \\
\hline & Bermmaaisel Overijssel & & neen & ja & 7 & neen \\
\hline & Bermmaaisel Hof van Twente & & ja & ja & 6 & neen \\
\hline & Bermmaaisel Noord-Brabant & & neen & ja & 5 & neen \\
\hline & Bermmaaisel Noord-Holland & $\mathrm{Hg}$ & ja & ja & 5 & neen \\
\hline 3 & Hooi & & ja & ja & 3 & neen \\
\hline 4 & Stro van koolzaad & $\mathrm{Cr}, \mathrm{Ni}, \mathrm{As}$ & neen & ja & 3 & neen \\
\hline \multirow[t]{2}{*}{5} & Tarwe GPS & & ja & ja & 7 & neen \\
\hline & Tarwestro & $\mathrm{Hg}, \mathrm{As}$ & ja & ja & 3 & neen \\
\hline \multirow[t]{2}{*}{6} & Erwt-GPS & $\mathrm{Cr}, \mathrm{Ni}, \mathrm{Pb}$ & $\mathrm{ja}$ & ja & 6 & neen \\
\hline & Erwtenvezel & As & ja & ja & 12 & $* 1$ \\
\hline
\end{tabular}




\begin{tabular}{|c|c|c|c|c|c|c|}
\hline \multirow[t]{7}{*}{$\mathbf{N r}$} & \multirow[t]{4}{*}{ Stof } & \multirow{4}{*}{$\begin{array}{l}\text { Ontbrekend } \\
\text { gegeven }\end{array}$} & \multicolumn{2}{|l|}{ België } & \multicolumn{2}{|c|}{ Denemarken } \\
\hline & & & Vracht & Vracht & Criterium & Gehalten \\
\hline & & & N-gift & fosfaatgift & dierlijke & $Z M$ op $P$ \\
\hline & & & & & mest, \% & \\
\hline & Erwtenpersvezel & As & ja & ja & 11 & neen \\
\hline & Erwtencrème & As & ja & ja & 9 & neen \\
\hline & Erwteneiwit & As & ja & ja & 10 & Neen \\
\hline \multirow[t]{7}{*}{10} & Bakkerijrestproducten (brood- en & $\mathrm{Cd}, \mathrm{Cr}, \mathrm{Hg}, \mathrm{Ni}$, & ja & ja & 3 & $*$ \\
\hline & deegresten) & $\mathrm{Zn}, \mathrm{As}$ & & & & \\
\hline & Retour brood bakkerijen & & ja & ja & 3 & neen \\
\hline & Broodproducten & $\mathrm{Cr}, \mathrm{Hg}, \mathrm{Ni}, \mathrm{As}$ & ja & ja & 4 & ja \\
\hline & Deeg & $\mathrm{Cr}, \mathrm{Cu}, \mathrm{Ni}, \mathrm{Zn}$ & ja & ja & 3 & neen \\
\hline & Brood en brooddeeg & & $*$ & $*$ & $*$ & $*$ \\
\hline & Brood- en banket datamontage & & ja & ja & 3 & neen \\
\hline 11 & Sojaboonmelasse & $\mathrm{Cr}, \mathrm{Ni}, \mathrm{As}$ & ja & $*$ & 7 & neen \\
\hline \multirow[t]{5}{*}{12} & Uiensap & & ja & ja & 46 & ja \\
\hline & Uienpulp & & ja & ja & 17 & neen \\
\hline & Uienreststromen (uienpellen) & & neen & ja & 5 & neen \\
\hline & Uienrestproducten datamontage & & neen & ja & 7 & neen \\
\hline & exclusief pellen & & & & & \\
\hline \multirow[t]{3}{*}{13} & Aardappelpersvezels & $\mathrm{Cr}, \mathrm{Hg}, \mathrm{Zn}, \mathrm{As}$ & ja & ja & 15 & neen \\
\hline & Aardappelvezel & & ja & ja & 14 & neen \\
\hline & Aardappelpersvezels, datamontage & & ja & ja & 9 & neen \\
\hline 14 & Gerstsubstraat (Bierbostel) & & ja & ja & 3 & neen \\
\hline 15 & Maïsgluten & $\mathrm{Cr}, \mathrm{Hg}, \mathrm{Ni}, \mathrm{As}$ & ja & ja & 3 & ja \\
\hline 16 & Melasse & & ja & ja & 3 & neen \\
\hline 17 & Raapzaadschroot & As & ja & ja & 3 & ja \\
\hline 18 & Perspulp van cichoreiwortel & & neen & neen & 10 & neen \\
\hline \multirow[t]{2}{*}{19} & Weipoeder derivaten (SCAL) & & ja & ja & 3 & ja \\
\hline & Wei gestandaardiseerd & & ja & ja & 3 & ja \\
\hline \multirow[t]{2}{*}{20} & Voedingsmiddelen slib & & ja & ja & 24 & Neen \\
\hline & (FanoFineFood) & & & & & \\
\hline \multirow[t]{7}{*}{21} & Tulp-broeierij-loof & & ja & ja & 30 & ja \\
\hline & Tulp-veld & & ja & ja & 7 & neen \\
\hline & Lelie-broeierij & & ja & ja & 20 & ja \\
\hline & Lelieveld gespoeld & & ja & ja & 17 & neen \\
\hline & Gladiool & & neen & ja & 8 & neen \\
\hline & Tulpenbollen & & ja & ja & 18 & ja \\
\hline & Tulpenblad & & ja & ja & 18 & ja \\
\hline 22 & Glycerine van dierlijke herkomst & & ja & ja & 3 & neen \\
\hline \multirow[t]{6}{*}{23} & Graanresten & & ja & ja & 3 & ja \\
\hline & Biograanmix & & ja & ja & 3 & ja \\
\hline & Tarwevoergriespellets & & ja & ja & 3 & ja \\
\hline & Gersteslijpmeelpellets & & ja & ja & 3 & ja \\
\hline & Gerstpellen & & ja & ja & 3 & ja \\
\hline & Graanresten datamontage & & ja & ja & 3 & ja \\
\hline 24 & Koffiedik & & ja & ja & 5 & neen \\
\hline 25 & Bietenperspulp & & ja & ja & 9 & neen \\
\hline 26 & Aardappelstoomschillen & & ja & ja & 20 & ja \\
\hline \multirow[t]{4}{*}{27} & Maïsfermentatieresten uit Zeafuel- & & ja & ja & 29 & neen \\
\hline & proces & & & & & \\
\hline & Graanspoeling literatuur & $\mathrm{Cr}, \mathrm{Hg}, \mathrm{Ni}, \mathrm{As}$ & ja & ja & 37 & neen \\
\hline & DDGS & $\mathrm{Cr}, \mathrm{Cu}, \mathrm{Ni}$ & ja & ja & 3 & ja \\
\hline
\end{tabular}




\section{$6 \quad$ Synthese en conclusies}

\subsection{Algemeen}

Het resultaat van deze studie is gebaseerd op het toepassen van expert judgement en heeft geleid tot het opstellen van drie alternatieve beoordelingssystematieken voor overige organische microverontreinigingen (OOM). De keuze voor een alternatief wordt bepaald door de toelaatbaar geachte milieubezwaarlijkheid. Daarnaast werd door het ministerie van EZ verzocht om bij de risicobeoordeling mogelijkheden van rubricering van afval- en reststoffen volgens Euralcodes te betrekken. Een Euralcode zou een representatieve maatstaf kunnen zijn om bepaalde risico's op milieubezwaarlijkheid verbonden aan bepaalde (groepen van) contaminanten te beheersen.

Productie van levensmiddelen en veevoeders vindt plaats in een $\mathrm{GMP}^{+}$gecertificeerde omgeving. Grondstoffen bij deze productie zijn geen afval- of reststoffen, Euralcodes hebben dan niets van doen met GMP ${ }^{+}$. Afval- en reststoffen die vrijkomen bij VGI en veevoederindustrie kunnen weer als afvalstof worden aangemerkt waardoor wel weer Euralcodes van toepassing zijn. In dit hoofdstuk wordt hierop nader ingegaan. Ten slotte worden algemene conclusies gegeven voor afval- en reststoffen van de 21+6 lijst voorgedragen door LTO-Noord/BBO en het ministerie van EZ voor de opname bijlage Aa van de Uitvoeringsregeling Meststoffenwet en worden aanbevelingen gedaan.

\subsection{Expert judgement}

In deze studie wordt een beoordeling gegeven van stoffen die door LTO-Noord/BBO en het ministerie EZ aangegeven zijn voor opname als covergistingsmateriaal in bijlage Aa van de URMW. De beoordeling is in hoofdzaak uitgevoerd op basis van bronnenonderzoek naar gehalten aan waardegevende bestanddelen en verontreinigende stoffen in samenhang met de processen waarbij de stoffen resteren. Deze studie gaat in op de risico's die verbonden zijn aan het gebruik van deze stoffen als covergistingsmateriaal. De studie wijkt af van het protocol dat nu nog gehanteerd wordt om covergistingsmaterialen te beoordelen op kwaliteit en in het bijzonder op milieuhygiënische risico's. Op basis van expert judgement zijn risico's in beeld gebracht. Daarvoor zijn generieke criteria opgesteld. Deze grijpen in op het na te streven beschermingsniveau. Hierbij heeft terugkoppeling plaatsgevonden met de TCB. Kritische noties bij de beoordeling van de stoffen en bij toepassing van de criteria van expert judgement zijn de volgende.

De herkomst van een aantal stoffen is helder evenals het productieproces waarbij deze stoffen resteren. Bij een aantal stoffen - zonnebloemen, erwten, sojasuiker, melasseslib, weiderivaten, voedingsmiddelenslib - was door de onvolledige beschrijving van de herkomst een risicobeoordeling mogelijk door condities op te leggen. Onvoldoende duidelijk is of deze condities daadwerkelijk geldig zijn voor de aangemelde stoffen.

Veel stoffen dienen de productie van veevoeder of zijn veevoeder. Bij - de productie van - veevoeders

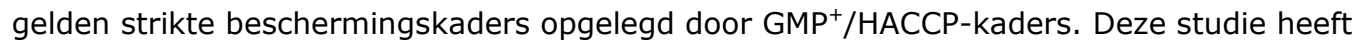
onvoldoende uitsluitsel gegeven of de aangemelde stoffen altijd zullen voldoen aan deze kaders. Het is goed denkbaar dat bij overaanbod op de veevoedingsmarkt een andere afzet voor de stoffen gezocht wordt. Toepassing als covergistingsmateriaal komt dan - als een verantwoord gebruik - in beeld. Risico's verbonden aan deze stromen zijn beheersbaar, hoewel dit nog niet hoeft te betekenen dat altijd voldaan zal worden aan criteria - ook bij toepassing van alternatieven voor beoordeling van OOM - voor de bescherming van gewas en milieu. De studie brengt niet in beeld wat de gevolgen zijn van stoffen die door een omstandigheid ongeschikt zijn geworden om verwerkt te worden tot levensmiddel of veevoeder of gebruikt te worden als levensmiddel of veevoeder. Daartoe dient informatie over de oorzaken bekend te zijn. Gegevens die NVWA verzameld heeft, gecombineerd met gegevens van levensmiddelenindustrie, VGI en veevoederindustrie dienen daarvoor te ontsloten 
worden. Die ontsluiting viel buiten de uitvoering van deze studie. Een aantal oorzaken schimmelaantasting, breuk, vocht - oefent geen nadrukkelijk effect uit op risico's als gevolg van toepassing van het digestaat, dat resteert na vergisting. Indien een anorganische of organische microverontreiniging de toepassing als levensmiddel of veevoeder of bij de productie ervan een oorzaak is voor het niet meer beantwoorden aan $\mathrm{GMP}^{+}$-criteria, dan heeft dit wel gevolgen voor de beoordeling van de risico's. Dit betreft partijen die nadere aandacht vragen.

De bijdrage van de stoffen aan de biogasproductie en de gaskwaliteit is ingeschat op basis van gegevens van de samenstellingen. Aanzienlijke gehalten aan ruwe celstof, ruw eiwit, ruw vet en suiker (mits verantwoord gedoseerd) geven een indicatie of de stoffen de potentie hebben om de biogasproductie te verhogen. Enkele stoffen werden voorzien van meetgegevens over de mate waarin de stoffen biogas leverden en de gaskwaliteit (koffiedik, bloembollen en bloembolresten). Het algemene beeld is dat de aangeboden stoffen een positieve bijdrage kunnen leveren aan de biogasproductie. Zeer natte producten, slurries of oplossingen, zijn vrijwel niet aangeboden. Weioplossingen kunnen door een (zeer) laag drogestofgehalte weinig bijdragen aan de biogasproductie. In Nederland wordt nu nog vrijwel uitsluitend nat vergist, d.w.z. dat in nat geroerde systemen mest en covergistingsmaterialen omgezet worden naar biogas. Bij vergisting van slurries hebben dergelijke oplossingen betekenis. Daardoor kan het vocht aangeleverd worden dat nodig is voor de procesvoering en droge producten compenseren.

Het volume van de beoordeelde stoffen varieert per stof. De meeste stoffen hebben een beperkt volume (Tabel 7). De volumes zijn veel kleiner dan de 72.700 kton dierlijke mest die in 2010 in Nederland werd geproduceerd (CBS StatLine). Die mest bevatte de residuen van de meeste grondstoffen na verwerking tot diervoeder waarvan het geraamde volume gegeven is in Tabel 7.

Als zodanig zullen in algemeen opzicht de risico's verbonden aan de stoffen mits GMP ${ }^{+}$-waardig t.o.v. van de risico's verbonden aan dierlijke mest beperkt zo niet gering zijn. Risico's van normoverschrijdende vrachten aan verontreinigende stoffen worden daarenboven beperkt door de corrigerende werking van de MW door sturing op stikstof en fosfaat. Ondernemers van vergistings-installaties kiezen ervoor, uit oogpunt van een stabiele productie van biogas, de rantsoenen weinig te laten variëren. Ervaring opgedaan met een covergistingsmateriaal leert of het een constant bestanddeel is van het rantsoen of niet. Deze werkwijze makt dat er onderscheid tussen bedrijven is in de keuze voor covergistingsmaterialen en daardoor in de milieuhygiënische kwaliteit van het resulterende digestaat. Er is meer zicht nodig over de verdeling van stoffen over bedrijven met vergistingsinstallaties.

De verzameling van de gehalten is verre van volledig. Gegevens over waardegevende bestanddelen zijn beschikbaar, gegevens over verontreinigende stoffen zijn schaars beschikbaar in publiek toegankelijke bronnen. Er is gebruik gemaakt van - geanonimiseerde - gegevens van eerder ingediende verzoeken voor opname van stoffen in bijlage Aa, ingediend bij het ministerie LNV-DKI en bij het ministerie EZ-DR (EZ-DR). Door - soms ingrijpende vormen van - datamontage zijn gegevens verkregen waarmee de beoordeling is uitgevoerd. Daardoor is een beeld van de stof en de mate van de aanwezigheid van verontreinigende stoffen verkregen maar er is geen zicht verkregen op de feitelijke samenstelling van de stoffen die daadwerkelijk vergist (zullen) worden. Veel gegevens van diverse bronnen zijn niet voorzien van informatie over het aantal monsters dat onderzocht werd en daardoor is de spreiding van de gehalten niet afdoende in beeld te brengen. Dit belemmert een verantwoorde beoordeling van risico's. De worst-case-benadering geeft voor een beperkt aantal stoffen aan dat naar redelijkheid de risico's beperkt zijn (zie paragraaf 4.29), maar voor veel stoffen is nader gericht onderzoek wenselijk om deze risico's concreet in beeld te brengen.

De beoordeling van de risico's voor mens, dier, gewas en milieu volgt het protocol. Bij risico's van residuen van OOM zijn alternatieven ontwikkeld om de systematiek van het protocol te beoordelen.

De beoordeling van zware metalen en arseen en van de organische microverontreinigingen die aangewezen zijn door de MW (OM) volgt het protocol. Er zijn geen alternatieven ontwikkeld in deze studie, zoals wel is uitgevoerd voor residuen van OOM. De jaarvrachten aan zware metalen en arseen zijn gebaseerd op de vracht die toegestaan is bij een dosering van zuiveringsslib bij 2 ton droge stof per ha. De grondslag voor de vrachten berust op beleidsafwegingen die in de jaren tachtig van de vorige eeuw werden gemaakt op basis van technisch wetenschappelijke rapportages. 
De samenstellingseisen voor organische microverontreinigingen berusten op onderzoek van het RIVM (Olde Venterink en Linders, 1994). Dioxinen, PCB's en PAK's zijn contaminanten die nu nog steeds aandacht vragen. Daarentegen zijn de drin's, $\mathrm{HCH}^{\prime} \mathrm{s}, \mathrm{HCB}$ en DDT/DDD/DDE niet meer toegelaten in EU27; deze actieve stoffen werden uitgefaseerd. Een actualisatie op organische microverontreinigingenvoor de verhandeling van meststoffen is sinds 1994 niet meer uitgevoerd. Bij aanwijzen van de maximale jaarvrachten voor OM werd gekozen voor een vier maal hogere vracht dan gerapporteerd door Olde Venterink en Linders (1994).

Sinds de invoering van normen voor zware metalen en arseen en OM zijn inzichten door ontwikkelingen bij wetenschappelijk onderzoek naar het beschermingsniveau voor mens, dier, gewas en milieu van deze stoffen en van residuen van OOM veranderd en aan het veranderen. Ook Europa werkt aan normen van afval- en reststoffen. Een actualisering van normen is daardoor nodig.

Knelpunten bij de toelating van meststoffen en covergistingsmaterialen veroorzaakt door residuen van OOM hebben geleid tot voorstellen voor actualisering van de beoordelingssystematieken. Expert judgement heeft geleid tot drie verschillende systematieken voor beoordeling van deze residuen van OOM. De keuze voor een systematiek vraagt nog beleids afweging. Tabel 20 vat de aspecten samen die bij de beleidsafweging betrokken moeten worden. Toetsing volgens het protocol geeft de grootste bescherming, toetsing volgens alternatief 2 geeft de minste bescherming. Alternatief 3 is een uitwerking van het advies van de TCB.

Deze studie werd beperkt tot tien actieve stoffen uit de groep OOM. Door wijzigingen van de systematiek van de keuze van deze actieve stoffen werden uiteindelijk twaalf actieve stoffen betrokken bij de beoordeling. Om aan MTR of VR te kunnen toetsen zijn bodemnormen nodig. Die zijn echter vaak niet beschikbaar. Beter beschikbaar zijn normen voor de bescherming van water. Toepassing van waternormen vraagt een herleiding op basis van een geprotocolleerde systematiek naar ad-hoc bodemnorm (Herwijnen et al., 2009). Een ad-hoc norm fungeert als een indicatieve waarde, maar heeft niet de robuustheid van een gedegen norm. Pirimifos-methyl is beoordeeld op basis van een indicatieve waarde voor een ad-hoc bodemnorm. Van de geselecteerde actieve stoffen is pirimifos-methyl de actieve stof die vaak leidt tot een overschrijding van een milieutoets hetzij volgens het protocol, hetzij volgens één of meerdere alternatieven. Deels is dit uitsluitsel gebaseerd op meetgegevens, deels op toepassing van MRL. Beter zicht op de feitelijke gehalten in de stoffen die daadwerkelijk als covergistingsmateriaal worden gebruikt, is nodig. Indien pirimifos-methyl als residu in covergistingsmaterialen in meetbare gehalten wordt aangetroffen, verdient het aanbeveling om voor deze actieve stof een gedegen bodemnorm af te leiden.

De huidige beoordeling houdt alleen rekening met de geselecteerde actieve stoffen. De selectie berust op een prioritering op stoffen, die vermoedelijk kansrijk zijn om problemen te veroorzaken. Lang niet alle actieve stoffen zijn beoordeeld die in de praktijk worden toegepast (vergelijk de selectie met de lijst van actieve stoffen die bij de teelt van bloembollen en broei worden toegepast ${ }^{76}$, Bijlage 6 ). Residuen van actieve stoffen buiten de selectie kunnen een beoordeling veranderen. Dit is een voorbehoud bij de beoordeling van de stoffen van deze studie.

De huidige beoordeling houdt verder nog geen rekening met:

a) Toxische of persistente metabolieten van de actieve stoffen;

b) Risico's voor grondwater, deze zijn nog niet expliciet bekeken c.q. benoemd.

Ten opzichte van het protocol is een belangrijke wijziging dat bij de beoordeling nu ook de mate van afbraak van een actieve stof gedurende het vergistingsproces betrokken is bij de bepaling van de jaarvracht (Bijlage 5). De stoffen van de selectie worden anaëroob afgebroken waardoor hogere gehalten aan residuen van OOM mogelijk zijn zonder dat een maximum (hetzij volgens het protocol, hetzij volgens één van de alternatieven) wordt overschreden. Hierbij zijn aannames gedaan op basis van expert judgement. Verificatie van deze aannames is nodig om de feitelijke mate van afbraak in beeld te krijgen.

\footnotetext{
${ }^{76}$ Dagtekening 1 juli 2011
} 
Tabel 20

Overzicht van de opties voor de systematiek van de beoordeling van residuen van gewasbeschermingsmiddelen en biociden.

\begin{tabular}{|c|c|c|c|c|}
\hline Aspect & Protocol versie 2.1 & Alternatief 1 & Alternatief 2 & Alternatief 3 \\
\hline $\begin{array}{l}\text { Milieuhygiënisch } \\
\text { risico } \\
\text { (gevolgen voor } \\
\text { bodemkwaliteit; } \\
\text { grondwaterkwaliteit } \\
\text { is niet specifiek } \\
\text { meegenomen in } \\
\text { deze studie) }\end{array}$ & $\begin{array}{l}\text { = Verwaarloos- } \\
\text { baar risico } \\
\text { is bepalend voor de } \\
\text { maximale } \\
\text { jaarvracht: } \\
\text { bodemconcentratie } \\
\text { nooit hoger dan VR } \\
\text { t.g.v. toepassen van } \\
\text { digestaat } \\
\text { = Conform vigerend } \\
\text { bodembeleid (zie } \\
\text { ook TCB-advies): } \\
\text { voorzorgprincipe dat } \\
\text { geen extra belasting } \\
\text { van de bodem } \\
\text { plaatsvindt via } \\
\text { meststoffen }\end{array}$ & $\begin{array}{l}\text { = Maximaal } \\
\text { toelaatbaar risico } \\
\text { is bepalend voor de } \\
\text { maximale } \\
\text { jaarvracht: } \\
\text { bodemconcentratie } \\
\text { nooit hoger dan MTR } \\
\text { t.g.v. toepassen van } \\
\text { digestaat } \\
\text { = Exact 100x } \\
\text { soepeler dan } \\
\text { Protocol } 2.1 . \\
=\text { Niet conform } \\
\text { vigerend beleid: } \\
\text { belasting via } \\
\text { digestaat leidt tot } \\
\text { een verminderde } \\
\text { bodemkwaliteit } \\
\text { tot maximaal op } \\
\text { MTR-niveau: m.n. } \\
\text { voor stoffen met een } \\
\text { DT50 vanaf } 50 \\
\text { dagen zal de } \\
\text { jaargemiddelde } \\
\text { bodemconcentratie } \\
\text { eerder richting MTR } \\
\text { dan VR kunnen } \\
\text { gaan. }\end{array}$ & $\begin{array}{l}\text { = 10*Maximaal } \\
\text { toelaatbaar risico } \\
\text { is o.a. bepalend } \\
\text { voor de maximale } \\
\text { jaarvracht: } \\
\text { bodemconcentratie } \\
\text { nooit hoger dan } \\
\text { 10*MTR t.g.v. } \\
\text { toepassen van } \\
\text { digestaat en } 1 \text { jaar } \\
\text { na toepassing } \\
\text { steeds weer terug } \\
\text { op VR-niveau } \\
\text { = Ten hoogste } \\
\mathbf{1 0 0 0 x ~ s o e p e l e r ~} \\
\text { dan Protocol } 2.1 \\
=\text { Niet conform } \\
\text { vigerend beleid: } \\
\text { belasting via } \\
\text { digestaat leidt tot } \\
\text { een verminderde } \\
\text { mwaliteit tot } \\
\text { jaargemiddelde } \\
\text { bodemkwaliteit tot } \\
\text { maximaal } 1,7 * \text { MTR }\end{array}$ & $\begin{array}{l}\text { = Maximaal } \\
\text { toelaatbaar risico } \\
\text { is o.a. bepalend } \\
\text { voor de maximale } \\
\text { jaarvracht: } \\
\text { bodemconcentratie } \\
\text { nooit hoger dan MTR } \\
\text { t.g.v. toepassen van } \\
\text { digestaat en } 1 \text { jaar } \\
\text { na toepassing } \\
\text { steeds weer terug } \\
\text { op VR-niveau } \\
\text { = Ten hoogste } \\
\text { 100x soepeler dan } \\
\text { Protocol } 2.1 \\
=\text { Niet conform } \\
\text { vigerend beleid: } \\
\text { belasting via } \\
\text { digestaat leidt tot } \\
\text { een verminderde } \\
\text { maxititeit tot } \\
\text { jaargemiddelde } \\
\text { bodemkwaliteit tot } \\
\text { maximaal } 0,17 * \text { MTR }\end{array}$ \\
\hline $\begin{array}{l}\text { Bescherming van } \\
\text { mens en andere } \\
\text { organismen }\end{array}$ & $\begin{array}{l}\text { = Volledige } \\
\text { bescherming op } \\
\text { basis van VR: } \\
\text { alleen veilige } \\
\text { producten worden } \\
\text { toegelaten voor } \\
\text { landbouwkundig } \\
\text { gebruik (beschermt } \\
\text { tegen mogelijke } \\
\text { combinatiewerking } \\
\text { als gevolg van } \\
\text { aanwezigheid van } \\
\text { meerdere } \\
\text { verontreinigingen } \\
\text { tegelijk) }\end{array}$ & $\begin{array}{l}\text { = Verminderde } \\
\text { bescherming: op } \\
\text { individueel } \\
\text { stofniveau } \\
\text { bescherming op } \\
\text { MTR-niveau, maar } \\
\text { geen bescherming } \\
\text { tegen mogelijke } \\
\text { combinatiewerkin } \\
\text { g van meerdere } \\
\text { verontreinigingen } \\
\text { tegelijk. }\end{array}$ & $\begin{array}{l}\text { = Sterk } \\
\text { verminderde } \\
\text { bescherming: op } \\
\text { individueel } \\
\text { stofniveau geen } \\
\text { bescherming op } \\
\text { MTR-niveau wat } \\
\text { leidt tot een } \\
\text { groter risico van } \\
\text { niet-acceptabele } \\
\text { effecten; geen } \\
\text { bescherming } \\
\text { tegen mogelijke } \\
\text { combinatie- } \\
\text { werking van } \\
\text { meerdere } \\
\text { verontreinigingen } \\
\text { tegelijk. }\end{array}$ & $\begin{array}{l}\text { = Verminderde } \\
\text { bescherming: op } \\
\text { individueel } \\
\text { stofniveau } \\
\text { bescherming tot } \\
\text { op MTR-niveau en } \\
\text { een beperkte } \\
\text { bescherming } \\
\text { tegen mogelijke } \\
\text { combinatie- } \\
\text { werking van } \\
\text { meerdere } \\
\text { verontreinigingen } \\
\text { tegelijk. }\end{array}$ \\
\hline $\begin{array}{l}\text { Beleidsmatig risico } \\
\text { t.o.v. huidige } \\
\text { praktijk }\end{array}$ & Referentie-situatie & $\begin{array}{l}\text { Exact } 100 * \text { hogere } \\
\text { bodembelasting: } \\
=\text { voldoet niet aan } \\
\text { beleid tot behoud }\end{array}$ & $\begin{array}{l}\text { Ten hoogste } \\
1000 * \text { hogere } \\
\text { bodembelasting met } \\
\text { gegarandeerde }\end{array}$ & $\begin{array}{l}\text { Exact } 100 * \text { hogere } \\
\text { bodembelasting met } \\
\text { gegarandeerde } \\
\text { afname tot VR- }\end{array}$ \\
\hline
\end{tabular}




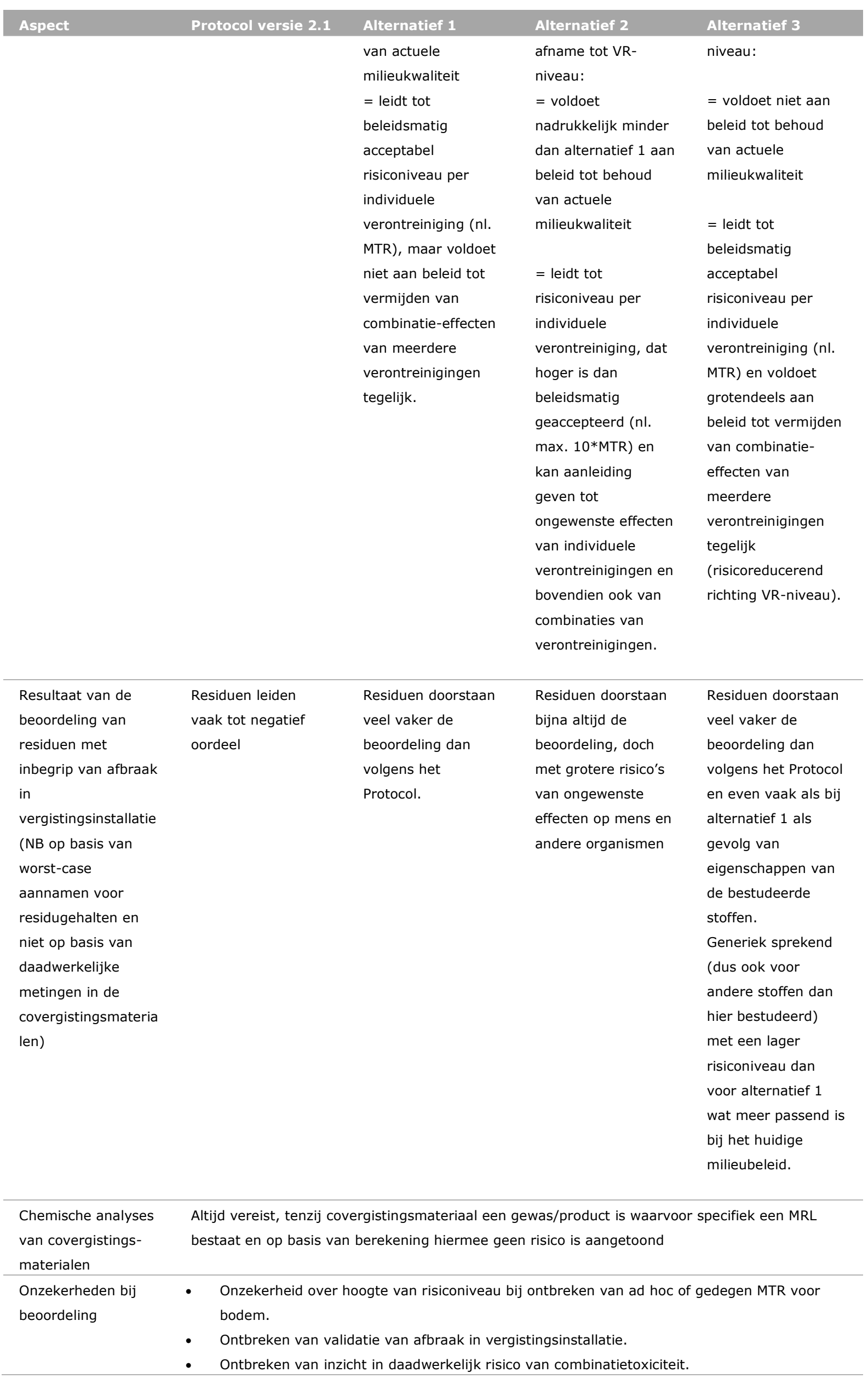


Nadrukkelijk moet nog eens gemeld worden dat voor alle hiervoor genoemde beoordelingswijzen (zowel volgens het protocol als volgens de drie alternatieven) geldt dat alleen de belasting van de bodem via de meststof of het covergistingsmateriaal in ogenschouw is genomen: dit betekent dat andere mogelijke belastingsroutes van de bodem (zoals gebruik van gewasbeschermingsmiddelen) een (aanzienlijke) extra belasting teweeg kunnen brengen, die geen onderdeel vormt van de beoordelingsmethodiek. Vandaar dat een zekere terughoudendheid voor het toelaatbaar achten van hogere vrachten ten gevolge van stoffen in meststoffen of co-vergistingsmaterialen wenselijk is.

Alternatief 1 heeft als aandachtspunt dat de vracht via mogelijke belastingsroutes ernstig verhoogd kan worden, ver boven VR. Alternatief 3 kent dit aandachtspunt niet.

Alternatief 2 kan voor de humane toxiciteit (directe en indirecte blootstelling via bv. voedsel) een groter probleem opleveren dan voor andere organismen (zie ook Figuur 1). Voor de humane toxiciteit via voedsel wordt bij normstelling uitgegaan van een maximale bijdrage van $10 \%$ van de dagelijkse toelaatbare inname (ADI). Een factor 10 op het MTR betekent dan dat de maximale bijdrage dus tot $100 \%$ wordt opgehoogd: ofwel een residu mag dan voor $100 \%$ aan de opvulling van de ADI bijdragen.

$\mathrm{Nu}$ is voor de huidige set van stoffen (voor zover informatie beschikbaar was) steeds de niet-humane toxiciteit bepalend geweest voor de (indicatieve) waarden voor het VR, dus voor de huidige set van stoffen lijkt dit aspect minder relevant. Daarnaast neemt voor de set van stoffen de concentratie binnen 1 jaar af van max. 10*MTR naar VR (voorwaarde bij alternatief 2 ), dus zal de langdurige (jaargemiddelde) blootstellingsconcentratie van gewassen via de bodem lager zijn dan $10 *$ MTR (deze daalt immers binnen 1 jaar naar een 1000x lagere waarde).

\subsection{Risicobeperking door aansluiting op $\mathrm{GMP}^{+}$}

GMP staat voor Good Manufacturing Practice en is een productie gebaseerd op een kwaliteitszorgbenadering. Indien bij GMP ook HACPP (Hazard Analysis \& Critical Control Points) wordt toegepast, wordt gesproken van $\mathrm{GMP}^{+}$. GMP is geen hygiënecode, die worden opgelegd door HACPP. GMP ${ }^{+}$wordt toegepast bij levensmiddelen- en diervoederproductie. Onder $\mathrm{GMP}^{+}$geproduceerde levensmiddelen of grondstoffen voor levensmiddelen worden niet - direct -aangeboden als covergistingsmateriaal. Reststromen van levensmiddelen worden daarentegen vaak toegepast als (grondstof voor) diervoeder. Reststromen uit de levensmiddelenindustrie ressorteren daardoor onder bepalingen die gelden voor diervoeders. De GMP ${ }^{+}$-regeling voor (grondstoffen voor) diervoeders is in Nederland ingevoerd door het Productschap Diervoeder (PDV). Per 1 januari 2010 valt de $\mathrm{GMP}^{+}$-regeling onder $\mathrm{GMP}^{+}$International (www.gmpplus.org. $\mathrm{nl} /$ ).

Om de kwaliteit en veiligheid van diervoeders te garanderen wordt door de producenten boven op de wettelijke bepalingen gewerkt met het kwaliteitsborgingssysteem $\mathrm{GMP}^{+}$. De $\mathrm{GMP}^{+}$-regeling van $\mathrm{GMP}^{+}$ International is een kwaliteitsborgingsysteem voor de levering en productie van (grondstoffen voor) diervoeder. De regeling is van toepassing voor producenten en handelaren van verschillende diervoedertypen, voermengsels en diervoedergrondstoffen. De basis van het systeem bestaat uit ENISO 9001, ISO 22000 en de HACCP-principes (Hazard Analysis \& Critical Control Points). HACCP is een verplichting die geldt voor alle diervoederactiviteiten van primaire productie tot en met in de handel brengen en het vervoederen. Door de regeling waarborgen bedrijven dat (grondstoffen van) diervoeders aan de wettelijke voorschriften en eisen voldoen. De $\mathrm{GMP}^{+}$-systematiek moet voorkomen dat ongewenste stoffen (bijvoorbeeld glas, metaal, zware metalen, pesticiden, diergeneesmiddelen, toxines etc.) in diervoeders terechtkomen. De systematiek richt zich ook op de hygiënische productie van diervoeder om te voorkomen dat microbiologische besmettingen of verontreiniging met stoffen/producten plaatsvindt. De $\mathrm{GMP}^{+}$-bedrijven beschikken hiervoor over een centrale databank met daarin diervoedergrondstoffen die een hiervoor uitgevoerde risicobeoordeling positief doorstaan hebben en daarom alleen toegestaan zijn.

Onder de covergistingsmaterialen die ter beoordeling worden voorgelegd aan de CDM bevinden zich regelmatig producten van Nederlandse diervoederproducenten en die daarmee aan de eisen van de $\mathrm{GMP}^{+}$-regeling van $\mathrm{GMP}^{+}$International zullen voldoen. Hoewel de grondstoffen voor diervoeder- 
productie door een risicobeoordeling als veilig bestempeld zijn, betekent dit niet impliciet dat deze diervoeders ook de criteria voor de beoordeling van covergistingsmaterialen zullen doorstaan. Immers, de beschermingsdoelen en criteria van beide systematieken zijn niet hetzelfde. Residuen van contaminanten waaronder van residuen van gewasbeschermingsmiddelen en biociden, zoals worden aangetroffen in potentiele covergistingsmaterialen, leiden daardoor in de eerste beoordelingsstap voor OOM volgens het protocol regelmatig tot een negatief oordeel. Ook bij toetsing aan voorgestelde alternatieven voor de beoordelingssystematiek, wordt de milieutoets niet altijd doorstaan (Tabel 7). $\mathrm{GMP}^{+}$-waardige (grond)stoffen voor veevoeder worden in de tweede stap van de systematiek van het protocol getoetst of de dosering een praktische betekenis heeft indien de gift van de stof afgestemd wordt op de maximaal toelaatbare jaarvracht. De ervaring is dat bij de huidige detectielimieten ${ }^{77}$ vaak die tweede stap doorstaan wordt. Lindaan vormt hierop vaak een uitzondering. De door Olde Venterink en Linders (1994) afgeleide jaarvracht, ook na toepassing van de beleidsfactor 4, vraagt vaak een lagere detectielimiet (factor 10-50) om enig risico afdoend uit te sluiten. $\mathrm{GMP}^{+}$beperkt de risico's aanzienlijk.

\subsection{Risicobeperking door aansluiting op Eural-codes}

In de Eural (2001/119/EG) wordt door de Europese Commissie een lijst van afvalstoffen gegeven en ook wordt - voor sommige afvalstoffen - aangegeven of een afvalstof onder de categorie "gevaarlijk afvalstof" kan vallen. In Nederland is de Eural geïmplementeerd met de Regeling Europese afvalstoffenlijst. Onder Eural bestaat een lijst met afvalstofcategorieën, waarbij hoofdcategorie 02 onder meer afval van landbouw, tuinbouw, voedingsbereiding en -verwerking bevat. Onder afval van landbouw en tuinbouw valt onder meer de subcategorie "02 0103 Afval van plantaardige weefsels" en deze wordt in de EURAL niet geschaard onder de gevaarlijke afvalstoffen. Deze subcategorie van afvalstoffen wordt niet nader gespecificeerd door bijvoorbeeld minimale gehalten aan in deze afvalstoffen (al dan niet van nature) voorkomende stoffen te vermelden, zoals gehalten aan zware metalen of residuen van gewasbeschermingsmiddelen. In sommige andere afvalstofcategorieën is er wel sprake van een ondergrens voor contaminanten, waarboven de afvalstof als gevaarlijk wordt bestempeld. Verder wordt in de Eural ook als subcategorie 190604 digestaat van de anaërobe behandeling van dierlijk en plantaardig afval vernoemd.

Onder de subcategorie "Afval van plantaardige weefsels" valt een groot aantal van de covergistingsmaterialen die aan de CDM ter beoordeling worden voorgelegd. Daarnaast vallen de digestaten van subcategorie 190604 in de gevallen dat tenminste met 50\% dierlijke mest is vergist ook onder de te beoordelen afvalstoffen, maar dan op basis van de input aan covergistingsmaterialen. Onder de criteria van het protocol, maar ook nog onder de alternatieve beoordelingswijzen, kunnen residuen van gewasbeschermingsmiddelen aanleiding geven tot een negatieve beoordeling. Het vallen van een covergistingsmateriaal onder de subcategorie 020103 of 190604 van de EURAL zou dus niet zonder meer afdoende zijn om een product daarmee automatisch van een positief oordeel te voorzien op basis van Protocol 2.1 of van de alternatieven. Dit zal naar verwachting ook van toepassing zijn op andere afvalstofcategorieën van de Eural, die als niet-gevaarlijk worden bestempeld.

Een aantal andere afvalstoffen wordt pas als gevaarlijk bestempeld als er een minimumgehalte aan contaminanten aanwezig is. Daarmee levert de indeling als gevaarlijke afvalstof geen risicogerelateerd criterium op, zoals de beoordeling van covergistingsmaterialen hanteert; immers, eenzelfde (minimum)gehalte kan voor de ene stof al een ruime overschrijding van het milieuhygiënische beoordelingscriterium betekenen, terwijl eenzelfde (minimum)gehalte voor de andere stof daar nog ruim aan kan voldoen.

Het voorgaande betekent dat er naast de Eural-categorieën, welke op zich bruikbaar kunnen zijn voor een generieke omschrijving van covergistingsmaterialen, altijd aanvullende eisen van toepassing zullen moeten zijn om te voldoen aan de milieuhygiënische aspecten voor een positief oordeel over een covergistingsmateriaal (bijvoorbeeld samenstellingseisen in relatie tot $\mathrm{N}$ - en $\mathrm{P}_{2} \mathrm{O}_{5}$-gehalten).

\footnotetext{
${ }^{77}$ Deze detectielimieten begeven zich op het niveau van $0,001-0,005 \mathrm{mg} / \mathrm{kg}$.
} 


\subsection{Conclusies en aanbevelingen}

In deze studie is een lijst van 21+6 afval- en reststoffen beoordeeld op gebruik als covergistingmateriaal. De beoordeling volgt die van het Protocol Beoordeling Stoffen Meststoffenwet versie 2.1. Daarnaast zijn drie alternatieven betrokken bij de beoordeling van residuen van gewasbeschermingsmiddelen. Tabel 7 geeft het volledig resultaat. Dit resultaat wordt samengevat in Tabel 21. Er zijn maar weinig afval- en reststoffen waarbij afdoende feitelijke informatie beschikbaar was om tot oordeelvorming over te gaan. Vaker diende op basis van expert judgement oordeelvorming uitgevoerd te worden. Ten slotte bleek in het kader van deze studie bij tien afval- en reststoffen de gegevensverzameling onvoldoende te zijn om tot een verantwoorde risicobeoordeling te komen.

Bij het oordeel van stoffen die door LTO-Noord/BBO en het ministerie EZ aangemeld zijn voor het uitvoeren van een risico-analyse t.b.v. opname in bijlage Aa van de URMW, is de milieubezwaarlijkheid verbonden aan residuen van overige organische microverontreiningen (in deze studie residuen van gewasbeschermingsmiddelen) betrokken.

Tot 2008 werden meststoffen en covergistingsmaterialen beoordeeld op zware metalen en de organische microverontreinigingen aangewezen door de MW (OM). Indien daar reden voor was, met name door het productieproces waarbij de stof resteerde, werd een stof ook beoordeeld op andere verontreinigende organische microverontreinigingen waaronder residuen van gewasbeschermingsmiddelen (OOM). Sinds 1-1-2008 is de beoordeling van residuen van OOM een onderdeel van het protocol en krijgt daardoor altijd aandacht. Die beoordeling stoelt op het toepassen van een beoordelingssystematiek gebaseerd op VR. De toepassing van deze systematiek bouwt de grootste zekerheden in op het uitsluiten van risico's voor mens, dier, gewas en milieu van het gebruik van afval- en reststoffen als covergistingsmateriaal. Deze vorm van beoordeling leidt echter frequent tot een negatief oordeel over het plaatsen van een stof in bijlage Aa van de URMW. Dit knelde bij de toelating. Er zijn drie alternatieven opgesteld om dit knelpunt op te lossen ${ }^{78}$. De keuze voor een alternatief is afhankelijk van het beschermingsniveau dat de overheid kan en wenst na te streven. De alternatieven zijn opgesteld op basis van expert judgement en stoelen daarmee op aannames waardoor onzekerheden worden geïntroduceerd.

Daarnaast is de beoordeling uitgevoerd aan actieve stoffen die toegepast worden bij de $21+6$ stoffen die door LTO-Noord/BBO en het ministerie EZ werden voorgesteld. Deze selectie is niet representatief voor het gebruik van alle gewasbeschermingsmiddelen en biociden in Nederland of in EU27. Anderzijds behoren de geselecteerde stoffen wel tot groepen actieve stoffen die als groep belangrijke kenmerken delen.

Deze studie heeft de gevolgen voor de belasting van residuen van OOM niet betrokken bij het opstellen van de beoordeling. Tegen deze achtergrond worden de volgende aanbevelingen gedaan:

- Herzie de methodiek voor het bepalen van de maximale vracht in het protocol (Van Dijk et al., 2009; versie 2.1). Betrek bij de herziening de geconstateerde onzekerheden bij toepassing van het protocol en voorgestelde alternatieven.

- Betrek een groter aantal actieve stoffen bij het onderzoek en prioriteer deze stoffen op basis van

1. Hun frequentie van voorkomen,

2. De maximaal toelaatbare vracht gegeven een beleidsbeslissing voor een beschermingsniveau,

3. Het quotiënt van het jaarlijkse gebruiksvolume $(\mathrm{kg})$ in Nederland en de maximale vracht (g/ha).

De prioritering van deze actieve stoffen kan overigens uitgevoerd met andere prioriteringswijze dan in deze studie gehanteerd werden. Ontwerp hierbij een structuur voor groepen van actieve stoffen die onderling dusdanig op elkaar gelijken dat per groep één of enkele actieve stoffen afdoende zijn om breed te kunnen beoordelen op risico's verbonden aan het gebruik van afval- en reststoffen als covergistingsmateriaal. Zet het ontwerp zo op dat de resultaten ook toegepast kunnen worden bij de beoordeling van afval- en reststoffen als meststof.

\footnotetext{
${ }^{78}$ Beleidsafweging heeft geleid tot de keuze voor alternatief 3. De jaarvracht aan een organische microverontreiniging mag aanleiding geven tot maximaal tot MTR mits binnen één jaar door afbraak VR bereikt wordt.
} 
- Analyseer wat de gevolgen zijn van het gebruik van verschillende covergistingsmaterialen met verschillende residuen van OOM in één rantsoen op de risico's verbonden aan het resulterend digestaat.

- Ontwerp een matrix met de output van modelberekeningen voor het schatten van grondwaterconcentraties van actieve stoffen of persistente metabolieten voor verscheidene bodem-water partitiecoëfficiënten en DT50 waarden.

- Valideer de berekende vrachten werkzame stoffen in het digestaat met metingen.

- De metabolieten van de geselecteerde werkzame stoffen (10-12) zouden nog nader bekeken moeten worden. Er moeten duidelijke afspraken komen over het beoordelen van metabolieten in het digestaat.

- Breng een afbakening tussen stoffen die $\mathrm{GMP}^{+}$-gecertificeerd zijn en stoffen die daarbuiten vallen.

- Eural-codes bieden onvoldoende bescherming tegen risico's van verontreinigende stoffen. De Eural-codes, bij gebruik als rubriceringsmiddel van afval- en reststoffen, vragen aanvullende criteria om de milieuhygiënische kwaliteit te borgen. Ontwerp een systematiek voor deze borging.

- $\quad$ Er is meer zicht nodig op de verdeling van afval- en reststoffen over bedrijven met vergistingsinstallaties. Zijn er verschillen tussen de bedrijven in risico's van verontreinigende stoffen in het resulterende digestaat? Ontwerp een systematiek om risico's door een verschil in verdeling in beeld te brengen.

- Inventariseer welke van de aangeboden stoffen daadwerkelijk vergist worden, bemonster deze stoffen en analyseer op waardegevende bestanddelen en gehalten aan verontreinigende stoffen.

\section{Tabel 21}

Beoordelingsresultaat van de lijst met $21+6$ afval- en reststoffen.

\begin{tabular}{|c|c|c|}
\hline Stof & \multirow{2}{*}{$\begin{array}{l}\text { Oordeel } \\
\text { negatief }\end{array}$} & \multirow{2}{*}{$\begin{array}{l}\text { Toelichtende opmerking } \\
\text { Onvoldoende informatie }\end{array}$} \\
\hline $\begin{array}{l}\text { 1. Zonnebloemen (zonnenbloempitten, } \\
\text { geëxtraheerd zonnenbloemmeel }\end{array}$ & & \\
\hline 2. Bermgras & (negatief) & Individuele partijen positief \\
\hline 3. Hooi & (positief) & Beperkte informatie, expert judgement \\
\hline 4. Stro van koolzaad & (positief) & Beperkte informatie, expert judgement \\
\hline 5. Tarwe & negatief & $\begin{array}{l}\text { Residuen gewasbeschermingsmiddelen, onvoldoende } \\
\text { informatie }\end{array}$ \\
\hline 6. Erwten & (positief) & Beperkte informatie, expert judgement \\
\hline 7. Maïs & Toegelaten & Opgenomen in bijlage Aa van de URMW \\
\hline 8. Maïssilage van hele planten & Toegelaten & Opgenomen in bijlage Aa van de URMW \\
\hline 9. Beheersgras & Toegelaten & Opgenomen in bijlage Aa van de URMW \\
\hline 10. Bakkerij restproducten/koekmix & (positief) & Mits pirimifos-methyl beheerst wordt. \\
\hline 11. Sojasuiker & negatief & Onvoldoende informatie \\
\hline 12. Uienpulp & positief & Geldt voor uienpulp en uienperssap \\
\hline 13. Aardappelvezels & (positief) & Beperkte informatie, expert judgement \\
\hline 14. Bierbostel & (positief) & Mits pirimifos-methyl beheerst wordt. \\
\hline 15. Maïsgluten & (negatief) & Te beperkte informatie \\
\hline 16. Melasse (slib) & (positief) & Bietmelasse positief, onvoldoende informatie rietmelasse. \\
\hline 17. Raapschroot & positief & Geen \\
\hline 18. Cigarant (perspulp van cichoreiwortelen) & (positief) & Beperkte informatie, expert judgement. \\
\hline 19. Wei & positief & Geldt voor beoordeelde weiproducten. \\
\hline $\begin{array}{l}\text { 20. Slib dat vrijkomt bij de productie van } \\
\text { salades }\end{array}$ & (positief) & $\begin{array}{l}\text { Geldt voor beoordeelde reststof, onvoldoende informatie } \\
\text { overige slibben. }\end{array}$ \\
\hline $\begin{array}{l}\text { 21. Bloembollen }+ \text { Afval van sorteren van } \\
\text { bloembollen }\end{array}$ & (positief) & $\begin{array}{l}\text { Mits pirimifos-methyl beheerst wordt, gebruik } \\
\text { gewasbeschermingsmiddelen vormt aandachtspunt. }\end{array}$ \\
\hline 22. Glycerine van dierlijke oorsprong & negatief & Doorstaat de milieutoets niet. \\
\hline 23. Gersteslijpmeelpellets & (positief) & Mits pirimifos-methyl beheerst wordt. \\
\hline 24. Koffiedik & (positief) & Mits caffeïne beheerst wordt. \\
\hline 25. Bietenperspulp & (positief) & Beperkte informatie, expert judgement. \\
\hline 26. Aardappelstoomschillen & positief & Geen \\
\hline 27. Stillage & (positief) & Mits pirimifos-methyl beheerst wordt. \\
\hline
\end{tabular}




\section{Literatuur}

Aarnink, A., K. de Greef, T. Hermans, H. Langeveld, R. Leopold en J. Luttik, 2000. Functieanalyse diersystemen nu en in 2040. Werkgroep functieanalyse. Wageningen/Lelystad.

http://edepot.wur.nl/116324.

Angelova, V., R. Ivanova en K. Ivanov, 2004. Heavy metal accumulation and distribution in oil crops. Communication in Soil Science and Plant analysis 35 (17\&18), pp. 2551-2566.

Belder, P, 2011a. Toelatingsonderzoek restmaterialen bollenteelt voor co-vergisting. Praktijkonderzoek Plant \& Omgeving B.V. Bloembollen, Boomkwekerij en Fruit. Januari 2011. PPO nr. 3236083800 PT 13636.

Belder, P, 2011b. Beantwoording noodzakelijke informatie voor toetsing restmateriaal bloembollenteelt en broei als covergistingsmateriaal. Notitie van Praktijkonderzoek Plant \& Omgeving B.V. Bloembollen, Boomkwekerij en Fruit.

Boersma, A.R., en K. Hemmes, 2001. Inzet geavanceerde ECN biomassa-conversietechnologieën voor Nederlandse VGI-reststromen. Eindrapport NECST-project 249.402-0260. ECN-C-01-119, NOVEMprojectnummer 249.402-0260, ECN-projectnummer 7.2247.

Bondt, N. en M.J.G. Meeusen, 2008. Bijproducten voor biobrandstoffen. Rapport 3.08.01; ISBN/EAN: 97890-8615-203-2. LEI Wageningen UR, Den Haag.

Bondt, N., C.P.A. van Wagenberg, R.R.C. Bakker en S.R.M. Janssens, 2009. Biomassa voor veevoer en energie; Scenarioanalyse van verschuiving in grondstoffengebruik. Rapport 2009-048. ISBN/EAN: 97890-8615-364-0.

Bondt, N., B. Janssens en A. de Smet, 2010. Afval uit de landbouw. LEI Wageningen UR. LEI-nota 10-061. Projectcode 32066. Den Haag.

Bouwmeester, H., M.H. Bokma-Bakker, N. Bondt en J. van der Roest, 2006. Alternatieve aanwending van (incidentele) reststromen buiten de diervoedersector. RIKILT Wageningen UR. Rapport 2006.008 augustus 2006.

De Vries, B., A. de Jong, R. Rovers, F. Haccoû, J. Spijker, C. van den Berg, C. Niemeier, D. Frank en J. Westerink, 2008. Energie à la carte. De potentie van het landschap voor energiewinning. Wageningen, Alterra Wageningen UR, Alterra-rapport 1679.

Ehlert, P.A.I., K.B. Zwart en J.H. Spijker, 2010. Biogas uit bermmaaisel. Duurzaam en haalbaar? Alterra Wageningen UR. Alterra-rapport 2064.

Froehner, S., W. Piccioni, K. Scurupa Machado en M.M. Mansur Aisse, 2011. Removal Capacity of Caffeine, Hormones, and Bisphenol by Aerobic and Anaerobic Sewage Treatment. Water Air Soil Pollution, 216:463-471. DOI 10.1007/s11270-010-0545-3.

Herwijnen, R. van, P.J.C.M. Janssen, T.H.A. Haverkamp en L.R.M. de Poorter, 2009. Handreiking voor de afleiding van indicatieve milieurisicogrenzen (Interimversie 2009). RIVM-rapport 601782025/2009., http://www.rivm.nl/bibliotheek/rapporten/601782025.pdf.

Hoop, D.W. de, P.A.I. Ehlert, J.H. Horrevoets \& N.C. Tomson, 2010. Alternatieve vormen van regulering van covergistingsmaterialen. LEI-rapport 2010-047 (http://edepot.wur.nl/142386). LEI Wageningen UR, Den Haag.

Janssens, B., H. Prins, M. van der Voort, B. Smit, B. Annevelink en M. Meeusen, 2005. Beschikbaarheid koolzaad voor biodiesel. Rapport 6.05.07 LEI Wageningen UR, Den Haag.

Koppejan, J., W. Elbersen, M. Meeuwsen en P. Bindraban, 2009. Beschikbaarheid van Nederlandse biomassa voor electriciteit. Procede Biomass B.V. In opdracht van SenterNovem, november 2009, projectnummer 200809.

Luske, B., en H. Blonk, 2009. Milieueffecten van dierlijke bijproducten. Blonk Milieuadvies BV. Gouda. http://www.blonkmilieuadvies.nl/nl/pdf/pbl_bijproducten_eindrapport.pdf.

Meeusen M, J. Schroot, W. Mulder en W. Elbersen, 2008. Verwaarding reststroom uienbewerking. Rapport van WUR-A\&F in opdracht van ZUVER, $155 \mathrm{pp}$. 
Olde Venterink, H.G.M., J.B.H.J. Linders, 1994. Standards for the concentrations of organic micro contaminants in organic fertilizers: a proposal for their derivation. RIVM Rapport nr. 679101007. http://www.rivm.nl/bibliotheek/rapporten/679101007.html

Oosterhout T. van en W. van Laarhoven, 2003. Het gebruik van reststoffen van de voedings- en genotmiddelenindustrie in de veevoeding Een verkennend onderzoek naar risicobeleving, risico's en risicobeheersing. Rapport Bureau SIRNED voor Stuurgroep Technology Assessment van LNV. Culemborg.

PDV, 2007. Productschap Diervoeder, 2007. Risicobeoordeling sojaolie-industrie, Versie 09-01-2007. Code: 3012E; http://www.gmpplus.org/downloads/Risicobeoordeling_Sojaolie-industrie_09-012007_EINDVERSIE[1].pdf (link inmiddels verwijderd).

Poniedziałek, M., A. Sękara, J. Ciura en E. Jędrszczyk, 2005. Nickel and manganese accumulation and distribution in organs of nine crops. Folia Horticulturae 17/1: 11-22.

Remmelink, G., K. Blanken, J. van Middelkoop, W. Ouweltjes en H. van Wemmenhove, 2010. Handboek Melkveehouderij. Wageningen UR Livestock Research. Handboek 18.

Singh, R. H. Singh en T.S. Kathpal, 1998. Harvest time residue of lindane, chlorpyriphos and quinalphos in mustard (Brassica juncea) and sunflower (Helianthus annus L.) seeds. Pesticide research journal 10(2): 219-223.

Shober, A.L., R.C. Stehouwer en K.E. MacNeal, 2007. Chemical Fractionation of Trace Elements in BiosolidAmended Soils and Correlation with Trace elements in Crop Tissue. Communications in Soil Science and Plant Analysis 38 (7): 1029-1046.

Spijker, J.H., P.A.I Ehlert, J.J. de Jong, C.M. Niemeijer, P.C. Scheepens en E.A. de Vries, 2004. Geschiktheid van bermmaaisel als meststof; Een verslag van acht praktijkproeven. Alterra Wageningen UR. Alterrarapport 963.

Technische Commissie Bodembescherming (TCB), 2010. Advies Covergisting, TCB A065(2010) van 23-122010.http://www.tcbodem.nl/publicaties/alle-publicaties/easytablerecord/1-publicaties/1

Tijmensen, M., R. van den Broek, B. van Dun, F. Schillig, J. Holm-Nielsen, I. Kuanto en D. Martin, 2003. Internationale verkenning mestvergisting. NOVEM (Nederlandse Organisatie voor Energie en Milieu),Projectnummer: 0377-02-02-03-28 (4700003707).

Uhnak, J., M. Veningerova en I. Horvathova, 1983. Chlorinated pesticides residues in the production of edible oils. Food science and technology 16(6): 323-325.

Umweltbundesamt, 2004. Erfassung von Schwermetallströmen in landwirtschaftlichen Tierproduktionsbetrieben und Erarbeitung einer Konzeption zur Verringerung der Schwermetalleinträge durch Wirtschaftsdünger tierischer Herkunft in Agrarökosysteme. Texte 06/04. Umweltforschungsplan des Bundesministeriums für Umwelt, Naturschutz und Reactorsicherheit. Forsuchungsbericht 29972104. UBA-FB 000580. ISSN 0722-186X.

Van Dijk, B., 2008. Onderzoek in de Gentse kanaalzone Onderzoek naar mogelijkheden tot uitwisseling en valorisatie. http://www.dbt.ugent.be/pdf/reststromen_eindpublicatie.pdf.

Van Dijk, T.A., J.J.M. Driessen, P.A.I. Ehlert, P.H. Hotsma, M.H.M.M. Montforts, S.F. Plessius \& O. Oenema, 2009. Protocol Beoordeling Stoffen Meststoffenwet. Versie 2.1. WOT werkdocument 167, 74 blz.

Verbong, G., A. van Selm, R. Knoppers en R. Raven, 2001. Een kwestie van lange adem. De geschiedenis van duurzame energie in Nederland. Æneas uitgeverij van vakinformatie b.v., ISBN 90-75365-44-6.

Vlaamse Overheid, Ruimtelijke Ordening, Woonbeleid en Onroerend Erfgoed - Omzendbrief RO/2006/01 betreffende het afwegingskader en de randvoorwaarden voor de inplanting van installaties voor mestbehandeling en vergisting [C - 2006/36684] 19 MEI 2006, Bijlage 1. Positieve lijst. http://staatsbladclip.zita.be/staatsblad/wetten/2006/10/24/wet-2006036684.html

VROM, 2004. (Inter)nationale Normen Stoffen. Den Haag, Nederland: Ministerie VROM.

VROM. 2008. NOBO: Normstelling en bodemkwaliteitsbeoordeling. Onderbouwing en beleidsmatige keuzes voor de bodemnormen in 2005, 2006 en 2007. Den Haag, Nederland: Ministerie VROM.

Wijnholds, K.H., 2008. Energieteelt in de Veenkoloniën 2006. Praktijkonderzoek Plant \& Omgeving B.V. PPO nr. 3250054900. http://edepot.wur.nl/29468.

Wijsman, H., 2011. Land- en tuinbouwcijfers 2011. LEI, Wageningen UR. Den Haag, Rapport 2011-029; ISBN 1386-9566. 


\section{Verantwoording}

De auteurs bedanken allen voor hun bijdrage aan het tot stand komen van deze rapportage.

Dit rapport komt voor uit een verzoek van het toenmalige ministerie van Economische Zaken, Landbouw en Innovatie, thans het ministerie van Economische Zaken. De studie is uitgevoerd door Alterra (thans Wageningen Environmental Research), NMI en RIVM. De kwaliteit wordt geborgd door toepassing van kwaliteitssystemen. WOt-technical report 70 is zowel door Wageningen Universiteit en Research als door RIVM onderworpen aan een interne review. 



\section{Bijlage 1 Samenstelling van de werkgroep}

Ir. P.A.I. Ehlert (Wageningen Environmental Research (Alterra))

Ir. L.R.M. de Poorter (RIVM)

Ir. J.H.B.J. Linders (RIVM)

Dr. J. Struijs, (RIVM)

Dr. J. Lijzen (RIVM)

Dr. H.J. van Wijnen (RIVM)

Ing. T.A. van Dijk (NMI)

Dr.ir. L. van Schöll (NMI) 



\section{Bijlage 2 Lijst met afkortingen}

\begin{tabular}{|c|c|}
\hline $\begin{array}{l}\text { Acroniem, } \\
\text { symbool }\end{array}$ & Betekenis \\
\hline CDM & Commissie Deskundigen Meststoffenwet \\
\hline $\mathrm{C}_{\max }$ & Maximale concentratie OOM door herhaald aanbrengen digestaat \\
\hline $\mathrm{C}_{\min }$ & Minimale concentratie OOM na 1 jaar (= VR bij alternatief 2 \& 3) \\
\hline $\mathrm{C}_{\mathrm{t}=0}$ & Concentratieverhoging van OOM direct na aanbrengen digestaat \\
\hline DT50 & Halfwaardetijd voor aërobe afbraak OOM in landbouwbodem \\
\hline FDA & US Food and Drug Administration \\
\hline GBM & Gewasbeschermingsmiddel \\
\hline GBK & Gewasbeschermingskennisbank \\
\hline GMP & Good manufacturing Practice \\
\hline $\mathrm{GMP}^{+}$ & Good manufacturing Practice and Hazard Analysis and Critical Control Points \\
\hline GPS & Gehele Plant Silage \\
\hline HACCP & Hazard Analysis and Critical Control Points \\
\hline $\mathrm{HC}_{5}$ & Hazardous concentration voor $5 \%$ van de organismen \\
\hline $\mathrm{K}_{\mathrm{p}}$ & Bodem-water partitiecoëfficiënt \\
\hline $\mathrm{K}_{\mathrm{ow}}$ & Octanol-water partitiecoëfficiënt \\
\hline MTR & Maximaal Toelaatbaar Risico \\
\hline $\mathrm{MTR}_{\mathrm{sb}}$ & Maximaal Toelaatbaar Risico standaardbodem \\
\hline $\mathrm{MTR}_{\mathrm{w}}$ & Maximaal Toelaatbaar Risico water \\
\hline MRL & Maximum Residue Level in voedingsstoffen/voedingsproducten \\
\hline MW & Meststoffenwet \\
\hline NAFTA & $\begin{array}{l}\text { North American Free Trade Agreement (overeenkomst tussen de Verenigde Staten van } \\
\text { Amerika, Canada en Mexico) }\end{array}$ \\
\hline NEVO & Nederlands Voedingsstoffenbestand \\
\hline NPK & Stikstof, Fosfor, Kalium \\
\hline NOEC & No Observed Effect Concentration in een chronische toxiciteitstest \\
\hline OM & Organische microverontreinigingen genoemd in de Meststoffenwet \\
\hline OOM & $\begin{array}{l}\text { Overige Organische Microverontreinigingen (o.a. residuen van gewasbeschermingsmiddelen en } \\
\text { biociden) }\end{array}$ \\
\hline PAF & Potentially Affected Fraction of species \\
\hline SSD & Species-sensitivity distribution (gevoeligheidsverdeling) \\
\hline $\mathrm{T}_{1 / 2}$ & Halfwaardetijd van anaërobe afbraak OOM in een vergistingstank \\
\hline THT & Tenminste Houdbaar Tot (Houdbaarheidsdatum voedingsmiddelen) \\
\hline T & Verblijftijd in een vergistingstank \\
\hline VGI & Voedings- en Genotsmiddelenindustrie \\
\hline UBMW & Uitvoeringsbesluit Meststoffenwet \\
\hline URMW & Uitvoeringsregeling Meststoffenwet \\
\hline VR & Verwaarloosbaar Risico (meestal MTR/100) \\
\hline
\end{tabular}





\section{Bijlage 3 Brief LTO-BBO}

Land- en Tuinbouw Organisatie Noord

Vestiging Zwolle

Ministerie van LNV

De heer H. Bos

Postbus 20401

2500 EK DEN HAAG

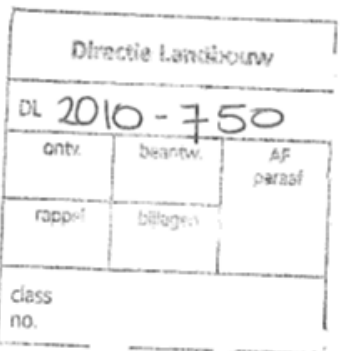

Referentie: $2010.0211 / \mathrm{MD} . g \mid$

$\begin{array}{llll}\text { Doorkiesnummer: } & 088-8886666 & \text { Datum: } 1 \text { april } 2010 \quad \text { Referentie: } & \text { 2010.0211/MD.gl } \\ \text { Faxnummer: } & 088-8886634\end{array} \quad$.

Betreft: Stoffen voor de positieve lijst

Geachte heer Bos, Beste Henri,

Tijdens het laatste overleg is over de positieve lijst afgesproken dat LTO en BBO stoffen zullen inventariseren waarvan we vinden dat die op de positieve lijst horen.

Deze inventarisatie is afgerond en heeft de volgende stoffen opgeleverd:

- Zonnebloemen

- bermgras

- hool

- stro van koolzaad

- tarwe

- erwten

- maïs en de silage van hele planten dit vooral voor biologische bedrijven

" beheersgras

- bakkerij restproducten / koekmix

- sojasuiker

- vienpulp

- aardappelvezels

- bierbostel

- maisgluten

- melasse(slib)

- raapschroot

- cigarant

- wei

- slib dat vrijkomt bij productie salades (bevat aardappelen en vet, producent is Fano Fine Foods)

- bloembollen

- afval van sorteren van bloembollen.

LTO Noord - Zwartewaterallee 14 - 8031 DX Zwolle - Postbus 240 - 8000 AE Zwolle

T 088 - 8886666 - F 088 - 8886660 - E info@itonoord.nl - I www.ltonoord.nI

Het hoofdkantoor is gevestigd in Zwolle 
De meeste van deze producten zijn wellicht al een keer aangemeld, maar afgewezen. We stellen voor om deze stoffen in ons volgend overleg te bespreken. Wanneer deze producten niet op de positieve lijst kunnen willen we graag weten waar de belemmering zit.

Deze brief is ook mede namens Eltjo van Marum van de Biogas Branche Organisatie verzonden.

\section{Met vriendelijke groet,}

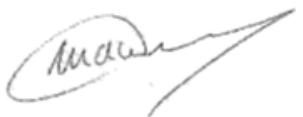

Menno Douma

cC: Ir. P.J.A.L. Munters 


\section{Bijlage 4 Gegevensbronnen van de dossiers}

\section{Zonnebloem}

Bondt, N., C.P.A. van Wagenberg, R.R.C. Bakker en S.R.M. Janssens, 2009. Biomassa voor veevoer en energie; Scenarioanalyse van verschuiving in grondstoffengebruik. Rapport 2009-048. ISBN/EAN: 97890-8615-364-0.

FAO, 2011. Food and Agriculture Organisation of the United Nations. FAO Statistical yearbook http://www.fao.org/economic/ess/ess-publications/ess-yearbook/ess-yearbook2010/en/

Wijnholds, K.H., 2008. Energieteelt in de Veenkoloniën 2006. Praktijkonderzoek Plant \& Omgeving B.V. PPO nr. 3250054900 . http://edepot.wur.nl/29468.

\section{1a. Zonnebloempitten}

Angelova, V., R. Ivanova en K. Ivanov, 2004. Heavy metal accumulation and distribution in oil crops. Communication in Soil Science and Plant analysis 35 (17\&18), pp. 2551-2566.

Adamse, P., J.J.M. Driessen, J. de Jong, A. van Polanen, H.J. van Egmond en A.W. Jongbloed, 2009. Trendanalyse zware metalen in diervoeder(grondstoffen). RIKILT - Instituut voor Voedselveiligheid, Wageningen Universiteit \& Research Centre, Rapport 2009.019.

CVB, 2010. Tabellenboek Veevoeding 2010.

Dauguet, S. 2009. Insecticide residues cross-contamination of oilseeds during storage (second part). OCL 16 nr. 3: 144-148.

Dauguet S., F. Fleurat-Lessard en J. Loison, 2010. Cross contamination of oilseeds by insecticides during storage.10th International working conference on stored product protection. Julius Kuhn Archiv. 425:827-832.

Gonzalvez, G.S., L.E. Pezzeta, M.M. Barros, G.K. Kleeman en D.F. Rocha, 2005. Effects of Phytase supplementation on apparent availability of $\mathrm{Mg}, \mathrm{Ca}, \mathrm{Zn}, \mathrm{Cu}, \mathrm{Mn}$, an Fe of plant feedstuffs for Nile tilapia. R. Bras. Zootec., v.34, n.6, p.2155-2163.

Lavado, R.S., 2006. Effects of sewage stludge application on soils and sunflower yield: quality and toxic element accumulation. Journal of plant nutrition 29. pp. 975-984.

Li, Y.M., R.L. Chaney, A.A. Schneiter en J.F. Miller, 1995. Combining ability and heterosis estimates for kernel cadmium level in sunflower. Crop Science 35(4): 1015-1019.

Li, Y.M, R.L. Chaney, A.A. Schneiter, 1994. Effect of soil chloride level on cadmium concentration in sunflower kernels. Plant and Soil 167: 275-280.

Miller N., H.E. Pretorius en L.J. Du Toit, 1986. Phytic acid in sunflower seeds, pressed cake and protein concentrate. Food Chemistry 21: 205-209

Sauvant, D., J.M. Perez en G. Tran, 2004. Tables of composition and nutritional value of feed materials. Wageningen academic publishers, NL \& INRA, Parijs FR. ISBN 978-90-76998-41-1

Senkoylu, N. en N. Dale, 1999. Sunflower meal in poultry diets: a review. World's Poultry Science Journal 55: $153-174$.

Simon, L. 1998. Cadmium accumulation and distribution in sunflower plant. Journal of plant nutrition, 21(2): 341-352.

Singh, R. H. Singh en T.S. Kathpal, 1998. Harvest time residue of lindane, chlorpyriphos and quinalphos in mustard (Brassica juncea) and sunflower (Helianthus annus L.) seeds. Pesticide research journal 10(2): 219-223.

Soylak, M., H. Colak, O. Turkoglu en M. Dogan. 2006. Trace metal content of snacks and appetizers consumed in Turkey. Bulletin of Environmental contamination and toxicology 76: 436-441. 
Uhnak, J., M. Veningerova en I. Horvathova, 1983. Chlorinated pesticides residues in the production of edible oils. Food science and technology 16(6): 323-325.

Raamsdonk, L.W.D. van, G.A.L. Meijer, H. Bouwmeester, C.A. Kan, W. Beek en P.A. Kemme, 2007. Schadelijke stoffen in de dierlijke productieketen, niveaus van voorkomen, normen en overdracht; Achtergrond en input voor ketenmodellering. Rikilt rapport 2007.001.

Walker J (2007) Oilseed Crops in Beef Cattle Rations. http://www.thebeefsite.com/articles/823/oilseedcrops-in-beef-cattle-rations

\section{1b. Zonnebloem, geëxtraheerd}

Albu, A., C. Pop C., F. Jârcă en I.M. Pop, 1999. Evaluation of copper concentration in some dairy cow feeding raw materials. Universitatea de Ştiinţe Agricole şi Medicină Veterinară Iaşi Lucrări Ştiinţifice - Seria Zootehnie, 52: 220-223.

Aslaksen, M.A., O.F. Kraugerud, M. Penn, B. Svihus, V. Denstadli, H.Y. Jørgensen, M. Hillestad, A. Krogdahl en T. Storebakken, 2007. Screening of nutrient digestabilities and intestinal pathologies in Atlantic salmon, Salmo salar, fed diets with legumes, oilseeds, or cereals. Aquaculture 272: 541-555.

Bondt, N., C.P.A. van Wagenberg, R.R.C. Bakker en S.R.M. Janssens, 2009. Biomassa voor veevoer en energie; Scenarioanalyse van verschuiving in grondstoffengebruik. Rapport 2009-048. ISBN/EAN: 97890-8615-364-0.

CVB, 2010. Tabellenboek Veevoeding 2010.

Krishnamoorthy, U., H. Soller, H. Steingass en K.H. Menke, 1995. Energy and protein evaluation of tropical feedstuffs for whole tract and ruminal inoculum studies in vitro. Animal Feed Science and Technology 52: 177-188

Miller N., H.E. Pretorius en L.J. Du Toit, 1986. Phytic acid in sunflower seeds, pressed cake and protein concentrate. Food Chemistry 21: 205-209.

San Juan, L.D. en M.J. Villamide, 2001. Nutritional Evaluation of Sunflower Products for Poultry as Affected by the Oil Extraction Process. Poultry Science 80: 431-437.

Senkoylu. N en N. Dale, 1999. Sunflower meal in poultry diets: a review. World's Poultry Science Journal 55: 153-174.

Tacon, A.G.J, J.L. Webster en C.A. Martinex, 1984. Use of solvent extracted sunflower seed meal in complete diets for fingerling rainbow trout (Salmo Gairdnere Richardson). Aquaculture 43: 382-289

Walker, J. 2007. Oilseed Crops in Beef Cattle Rations. http://www.thebeefsite.com/articles/823/oilseedcrops-in-beef-cattle-rations

\section{Bermmaaisel}

Gegevensformulier CoVe-13

Gegevensformulier CoVe-19

Gegevensformulier CoVe-20

Gegevensformulier CoVe-21

Bok, A.J., J. Kopinga, M. Schnaar en J.H. Spijker, 2001. Typologie bermgraskwaliteit. Typologie van de milieuhygiënische kwaliteit van bermgras voor het onderwerken op landbouwgronden. Alterra, Alterrarapport 246.

Ehlert, P.A.I., K.B. Zwart en J.H. Spijker, 2010. Biogas uit bermmaaisel. Duurzaam en haalbaar? Alterra. Alterra-rapport 2064.

Koppejan, J., J.A. Zeevalkink en W.F.M. Hesseling, 2001. De haalbaarheid van energieopwekking uit bermgras. Onderzoek uitgevoerd in het kader van het programma Energiewinning uit Afval en Biomassa (EWAB), NOVEM, Utrecht. 
Spijker, J.H., J. Harmsen, J.J. de Jong, C.M. Niemeijer, A. Gorissen, P.C. Scheepens en W. van der Zweerde, 2003. Bodemverbeterende eigenschappen van sloot- en oevermaaisel op landbouwgrond. STOWA rapport 2003-06

Spijker, J.H., P.A.I Ehlert, J.J. de Jong, C.M. Niemeijer, P.C. Scheepens en E.A. de Vries, 2004. Geschiktheid van bermmaaisel als meststof; Een verslag van acht praktijkproeven. Wageningen, Alterra, Alterrarapport 963

Spijker J.H. en P.A.I. Ehlert, 2004. Alternatieve verwerkingsmethoden en werkbare wetgeving voor berm-, oever- en slootmaaisel; Mogelijkheden voor het onderwerken van maaisel op landbouwgronden in een kleine en een grote kringloop. Wageningen, Alterra, Alterra-rapport 1071.

Vries, B., de, A. de Jong, R. Rovers, F. Haccoû, J. Spijker, C. van den Berg, C. Niemeier, D. Frank en J. Westerink, 2008. Energie à la carte. De potentie van het landschap voor energiewinning. Wageningen, Alterra, Alterra-rapport 1679.

Wegener, J.W.M., MJ.M. van Schaick, M. Razing en L. Burgers, 1991. Meting massastromen van polycyclische aromatische koolwaterstoffen naar de direkte omgeving van de weg (II). Instituut voor Milieuvraagstukken, Vrije Universiteit Amsterdam. IVM E 91/108.

\section{Hooi}

Albu, A., C. Pop C., F. Jârcă en I.M. Pop, 1999. Evaluation of copper concentration in some dairy cow feeding raw materials. Universitatea de Ştiinţe Agricole şi Medicină Veterinară Iaşi Lucrări Ştiinţifice - Seria Zootehnie, 52: 220-223.

Arthington, J.D. en F.M. Pat, 2002. Effect of corn- vs molasses- based supplements on trace mineral status in beef heifers. Journal of animal science 80: 2787-2791.

Boer, M. en K.J. Hin, 2003. Zware metalen in de melkveehouderij. Koeien \& kansen, rapport 16; CLM-nr. 587-2003, 59 pp.

Centraal Veevoederbureau, 2010. Tabellenboek Veevoeding 2010. Lelystad.

Costera, A.C., P. Feidt, P. Marchand, B. Le Bizec en G. Rychen. 2006. PCDD/F and PCB transfer to milk in goats exposed to a long-term intake of contaminated hay. Chemosphere 64. 650-657.pp.

Fourage handel J.A. de Boer ( http://www.jaboer.nl/

Fouragehandel HISFA, mondelinge mededeling de heer C. van Bloois.

Hulster, A. en H. Marschner. 1993. Transfer of PCDD/PCDF from contaminated soils to food and fodder crop plants. Chemosphere 27(1/3): 439-446.

Jones. R. en J.M. Forbes, 1984. A note on the effect of glyphosate and quinine on the palatability of hay for sheep Animal Production. 38: 301-303.

Koskamp, G.J. en M. Van Kuik, 1999. Zware metalen op De Marke. Interne notitie CLM, Utrecht.

Remmelink, G., K. Blanken, J. van Middelkoop, W. Ouweltjes en H. van Wemmenhove, 2010. Handboek Melkveehouderij. Wageningen UR Livestock Research. Handboek 18.

Shober, A.L., R.C. Stehouwer en K.E. MacNeal, 2007. Chemical Fractionation of Trace Elements in BiosolidAmended Soils and Correlation with Trace elements in Crop Tissue. Communications in Soil Science and Plant Analysis 38 (7): 1029-1046.

Smolders, G., N. van Eekeren en F. Neijenhuis, 2005. Vitaminen in rantsoenen voor biologisch melkvee. PraktijkRapport Rundvee 80.

Stoyke, M., K. Lusky, K.D. Doberschutz en R. Göbel, 1994. Untersuchungen zur belastung von futtermitteln, Obst und Gemüse mit Benzo(a)pyren (BaP) im Land Brandenburg. Die Nahrung 38(3), 259-266.

Umweltbundesamt, 2004. Erfassung von Schwermetallströmen in landwirtschaftlichen Tierproduktionsbetrieben und Erarbeitung einer Konzeption zur Verringerung der Schwermetalleinträge durch Wirtschaftsdünger tierischer Herkunft in Agrarökosysteme. Texte 06/04. Umweltforschungsplan des Bundesministeriums für Umwelt, Naturschutz und Reactorsicherheit. Forsuchungsbericht 29972104. UBA-FB 000580. ISSN 0722-186X. 
Walorczyk, S., 2008. Development of a multi-residue method for the determination of pesticides in cereals and dry animal feed using gas chromatography-tandem quadrupole mass spectrometry II. Improvement and extension to new analytes. Journal of Chromatography A 1208, 202-214.

Zadnik, T., I. Jazbec, J. Staric en V. Pori, 2004. Thirty years of investigation of lead (Pb) concentration in the soil, hay, silage and dairy cows blood in the Meza Valley. Krimiva 46(1): 3-9.

\section{Stro van koolzaad}

ADAS, 1975. Composition of oilseed rape straw. Science Service annual report 1975 Agricultural Development and Advisory Service UK.

Angelova, V., R. Ivanova en K. Ivanov, 2004. Heavy metal accumulation and distribution in oil crops. Communication in Soil Science and Plant analysis 35(17): 2551-2566.

Chomyszyn, M., 1980. Rapsstroh als futter fur Wiedekauer. Archiv fur Tierernahrung 30 (1/3): 299-302.

Gracey, H.I. en J.W.B. Stewart, 1974. Distribution of mercury in Saskatchewan soils and crops. Canandian Journal of Soil Science 54(1): 105-108.

Hocking, P.J. en M. Stapper, 2001. Effects of sowing time and nitrogen fertilizer on canola and wheat, and nitrogen fertiliser on Indian mustard. II Nitrogen concentrations, $\mathrm{N}$-accumulation, and $\mathrm{N}$ fertiliser use efficiency. Australian Journal of Agricultural Research, 52: 635-644.

Janssens, B., H. Prins, M. van der Voort, B. Smit, B. Annevelink en M. Meeusen, 2005. Beschikbaarheid koolzaad voor biodiesel. Rapport 6.05.07 LEI, Den Haag.

Santonoceto, C., P.J. Hocking, J. Braschkat en P.J. Randall, 2002. Mineral nutrient uptake and removal by canola, Indian mustard and Linola in tow contrasting environments, and implications for carbon cycle effects on soil acidification. Australian journal of Agricultural research 53: 459-470.

Sidlauskas, G. en P. Tarakanovas, 2004. Factors affecting nitrogen concentration in spring oilseed rape (Brassica napus L.). Plant, Soil and Environment 50(5): 227-234.

Urricariet, A.S., M.S. Zubillaga, M.M. Zublillaga en R.S. Lavado, 1995. Nitrogen, phosphorus, and potassium uptake of two rapeseed cultivars in an Argentinean soil. Journal of plant nutrition 18(2): 305-315.

\section{Tarwe}

Boer, H.C. de, G. van Duinkerken, A.P. Philipsen en H.A. van Schooten, 2003. Alternatieve Voedergewassen. Praktijkonderzoek Veehouderij. Praktijk Rapport Rundvee 27.

Centraal Veevoederbureau, 2010. Tabellenboek Veevoeding 2010. Lelystad.

Driehuis, F., M.C. Spanjer, J.M. Scholten en M.C. Te Giffel, 2008. Occurrence of mycotoxins in maize, grass and wheat silage for dairy cattle in the Netherlands, Food Additives and Contaminants: part B, 1: 1, 41 50. DOI: $10.1080 / 19393210802236927$.

Deisenroth, G., F. Hahn, J. Heyn, D. Koch en G. Völkel, 2008. Merkblatt Ökologischer Landbau Nährstoffvergleich als Flächenbilanz (früher: Feld-Stall-Bilanz) und Berechnung des betrieblichen Einsatzes von Wirtschaftsdüngern tierischer Herkunft (170 kg N/ha-Obergrenze). 2. Auflage, aktualisiert nach der DüV vom 27.02.2007. AG DüV. Leitfaden Hessen.

Lüdke, H., 2001. Der Beitrag von Maïs-, Gras-, Luzerne- und Ganzpflanzensilage zur Mineralstoffversorgung der Milchkühe in Thüringen. In: Fachberichte aus dem Untersuchungswesen. Schriftenreihe Heft 6 Untersuchungen zur productqualität: 41-45. http://dx.doi.org/10.1080/19393210802236927

Göhler, H. en Chr. Emmerling, 2007. Landwirtschaftliche Verwertung von Gärrückständen aus NaWaRo Biogasanlagen. Endbericht Mai 2007, FKZ: 22011201. Gefördert durch die Fachagentur für Nachwachsende Rohstoffe (FNR). Universität Trier, FB VI - Bodenkunde, D - 54286 Trier.

Smolders G. N. van Eekeren en F. Neijenhuis, 2005. Vitaminen in rantsoenen voor biologisch melkvee. Animal Sciences Group / Praktijkonderzoek. PraktijkRapport Rundvee 80.

Leiterer, M., A. Vetter en T. Hering. , 2001. Anorganisch-chemische Analyse von Biomasseaschen. In: Fachberichte aus dem Untersuchungswesen. Schriftenreihe Heft 6 Untersuchungen zur productqualität: 81-88. 
Van den Pol-Van Dasselaar, A. en A.C.M.M. Boomaerts, 2000. Vergelijking van teelt van Gehele Plant Silage en teelt van snijmaïs in Limburg. Praktijkonderzoek Rundvee, Schapen en Paarden (PR) Lelystad. PRrapport 190.

Wetter, C. en E. Brügging, 2005. Leitfaden zum Bau einer Biogasanlage. Von der Idee zum konkreten Vorhaben - Band I (überarbeitete Fassung, Stand: 01/05). Fachhochschule Münster. University of Applied Science.

\section{Erwt}

Adamse, P., J.J. M. Driessen, J. de Jong, A. van Polanen, H.J. van Egmond en A.W. Jongbloed, 2008. Trendanalyse zware metalen in diervoeder(grondstoffen). RIKILT - Instituut voor Voedselveiligheid. Rapport 2009-019.

Anonymus, 2001. Gebruik van plantaardige eiwitbronnen en eigen voederwinning. ALT-Demonstratieproject. Vereniging van Zelfmengers.

http://users.telenet.be/zelfmengers/Demoproject/Eindverslag\%20Literatuurstudie.pdf

Borreania, G., A.R. Chiona, S. Colombinib, M. Odoardi, R. Paoletti en E. Tabaccoa, 2009. Fermentative profiles of field pea (Pisum sativum), faba bean (Vicia faba) and white lupin (Lupinus albus) silages as affected by wilting and inoculation. Animal Feed Science and Technology 151: 316-323.

Centraal Veevoederbureau, 2010. Tabellenboek Veevoeding 2010. Lelystad.

Mustafa, A.F., D. A. Christensen, en J. J. McKinnon, 2000. Effects of Pea, Barley, and Alfalfa Silage on Ruminal Nutrient Degradability and Performance of Dairy Cows. J. Dairy Sci. 83:2859-2865.

Mustafa, A. F., P. Seguin, D. R. Ouellet en I. Adelye, 2002. Effects of Cultivars on Ensiling Characteristics, Chemical Composition, and Ruminal Degradability of Pea Silage. J. Dairy Sci. 85:3411-3419.

Richtlijn 2002/32/EG van het Europees parlement en de Raad van 7 mei 2002 inzake ongewenste stoffen in diervoeding. Gewijzigd bij Richtlijn 2003/57/EG, Richtlijn 2003/100/EG, Richtlijn 2005/8/EG, Richtlijn 2005/86/EG, Richtlijn 2005/87/EG, Richtlijn 2006/13/EG, Richtlijn 2006/77/EG, Richtlijn 2008/76/EG, Richtlijn 2009/8/EG, Verordening 219/2009, Richtlijn 2009/124/EG, Richtlijn 2009/141/EG, Richtlijn 2010/6/EG.

\section{Brood- en deegresten}

Gegevensformulier CoVe 8

Gegevensformulier CoVe 29

Gegevensformulier CoVe 38

Gegevensformulier CoVe 97

Gegevensformulier CoVe 104

Gegevensformulier CoVe 108

Bondt, N. en M.J.G. Meeusen, 2008. Bijproducten voor biobrandstoffen. LEI. Rapport 3.08.01; ISBN/EAN: 978-90-8615-203-2.

Bouwmeester, H., M.H. Bokma-Bakker, N. Bondt en J. van der Roest, 2006. Alternatieve aanwending van (incidentele) reststromen buiten de diervoedersector. RIKILT Rapport 2006.008 augustus 2006.

Darnerud, P.O., S. Atuma, M. Aune, R. Bjerselius, A. Glynn, K. Petersson Grawe en W. Becker, 2006. Dietary intake estimations of organohalogen contaminants (dioxins, PCB, PBDE and chlorinated pesticides, e.g. DDT) based on Swedish market basket data. Food and Chemical Toxicology 44: 1597-1606.

Nederlands Voedingsstoffenbestand (NEVO-online versie 2010/2.0,@RIVM)

Oosterhout T. van en W. van Laarhoven, 2003. Het gebruik van reststoffen van de voedings- en genotmiddelenindustrie in de veevoeding Een verkennend onderzoek naar risicobeleving, risico's en risicobeheersing. Rapport Bureau SIRNED voor Stuurgroep Technology Assessment van LNV. Culemborg.

Umweltbundesamt, 2004. Erfassung von Schwermetallströmen in landwirtschaftlichen Tierproduktionsbetrieben und Erarbeitung einer Konzeption zur Verringerung der Schwermetalleinträge 
durch Wirtschaftsdünger tierischer Herkunft in Agrarökosysteme. Texte 06/04. Umweltforschungsplan des Bundesministeriums für Umwelt, Naturschutz und Reactorsicherheit. Forsuchungsbericht 29972104. UBA-FB 000580. ISSN 0722-186X.

\section{Sojasuiker}

Gegevensformulier CoVe 82

ABS Europe, fact sheet sojasuiker 35\%, http://www.agribiosource.com/internet_pdf/pdf_64.pdf

Bell, M. J., M. J. McLaughlin, G. C. Wright, en A. Cruickshank, 1997. Inter- and intra-specific variation in accumulation of cadmium by peanut, soybean, and navybean. Aust. J. Agric. Res., 48: 1151-1160.

Braude, G.L, A.M. Nash, W.J. Wolf, R.L. Carr en R.L. Chaney, 1980. Cadmium and lead content of soybean products. J. of Food Science 45: 1187-1189, 1190.

Centraal Veevoederbureau, 2010. Tabellenboek Veevoeding 2010. Lelystad.

Endres, J., 2001. Soy Protein Products Characteristics, Nutritional Aspects, and Utilization. Revised and Expanded Edition. AOCS Press. Champaign, Illinois, USA.

FAOSTAT, 2011. Food and agriculture organisation of the United Nations. Statistics Devision, http://faostat.fao.org/

Karp, S.G., 2007. Production of L-Lactic acid from the soybean vinasse. Thesis. Dissertação apresentada como requisito parcial à obtenção do título de Mestre em Processos Biotecnológicos, do Programa de PósGraduação em Processos Biotecnológicos, Área de Concentração Agroindústria, da Universidade Federal do Paraná.

Lavado, R.S., C.A., Porcelli en R. Alverez, 2001. Nutrient and heavy metal concentration and distribution in corn, soybean and wheat as affected by different tillage systems in the Argentine Pampas. Soil \& Tillage Research 62: 55-60.

Nederlands Voedingsstoffenbestand (NEVO-online versie 2010/2.0,@RIVM).

Patel, D, R. Kumar en S. Prasad, 2004. Variation in the chemical constituents of soybean due to industrial pollution. J. Serb. Chem. Soc. 69 (8-9): 635-640.

Siqueira, P.F., S.G. Karp, J.C. Carvalho, W. Sturm, J.A. Rodríguez-León, J.L. Tholozan, R.R. Singhania, A. Pandey en C.R. Soccol, 2008. Production of bio-ethanol from soybean molasses by Saccharomyces cerevisiae at laboratory, pilot and industrial scales. Bioresource Technology 99: 8156-8163.

Yilmaz, E., 2010. Changes of some soil properties by agricultural processing waste (soybean pulp) amendment. Journal of Food, Agriculture \& Environment, Vol.8 (3\&4), July-October 1057-1060.

Zhanga, Z.W., Watanabeb, T., Shimboc, S., Higashikawad, K. en Ikedad, M., 1998. Lead and cadmium contents in cereals and pulses in north-eastern China. The Science of the Total Environment 220: 137145.

\section{Uienpulp}

Gegevensformulier CoVe 40

Gegevensformulier CoVe 67

Gegevensformulier CoVe 84

Verzoek CDM 16

Verzoek CDM 42

Boersma, A.R. en K. Hemmes, 2001. Inzet geavanceerde ECN biomassa-coversietechnologieën voor Nederlandse VGI-reststromen. Eindrapport NECST-project 249.402-0260. ECN-C-01-119, NOVEMprojectnummer 249.402-0260, ECN-projectnummer 7.2247.

Koppejan, J., W. Elbersen, M. Meeuwsen en P. Bindraban, 2009. Beschikbaarheid van Nederlandse biomassa voor electriciteit. Procede Biomass B.V. In opdracht van SenterNovem, november 2009, projectnummer 200809. 
Meeusen M, J. Schroot, W. Mulder en W. Elbersen, 2008. Verwaarding reststroom uienbewerking. Rapport van WUR-A\&F in opdracht van ZUVER, $155 \mathrm{pp}$.

\section{Aardappelpersvezels}

Gegevensformulier CoVe 5

\section{Verzoek CDM 41}

Centraal Veevoederbureau, 2010. Tabellenboek Veevoeding 2010. Lelystad.

Adamse, P., J.J.M. Driessen, J. de Jong, A. van Polanen, H.J. van Egmond en A.W. Jongbloed, 2009. Trendanalyse zware metalen in diervoeder(grondstoffen). RIKILT - Instituut voor Voedselveiligheid, Wageningen Universiteit \& Research Centre, Rapport 2009.019.

Productinformatie van handelshuizen: Hedimix: http://www.hedimix.nl/nl/productassortiment/view-65.html Jan Bakker bv. http://www.janbakker.nl/items.php?taalid=1\&prodid=1\&hcat=1\&scat=2

Deltavoeders bv. http://www.deltavoeders.nl/assortiment/natte-bijprodukten/aardappelpersvezels.html

Farmfeed bv. http://www.farmfeed.eu/nl/?page_id=1211\&prodid=1030

CZAV http://www.czav.nl/dynamisch/bibliotheek/378_0_NL_Aardappelpersvezels.pdf

Beuker, http://www.beuker.net/nl/rundveehouderij/producten/energierijk/steekvast/aardappelpersvezels

Bonda's veevoederbureau bv.: http://www.bonda.nl/nl/rundvee/produktinformatie/download?file=Aardappelpersvezels\%2020100701.pdf

Duynie B.V, www.duynie.nl/duynie/download/749040_Aardappelpersvezels.pdf

Kool, A., A.W. Jongbloed, S.W. Moolenaar, G.J. Hilhorst en F.C. van der Schans, 2006. De aanpak van zware metalen op melkveebedrijven. CLM Onderzoek en advies B.V.

Koppejan, J., W. Elbersen, M. Meeuwsen en P. Bindraban, 2009. Beschikbaarheid van Nederlandse biomassa voor electriciteit. Procede Biomass B.V. In opdracht van SenterNovem, november 2009, projectnummer 200809.

Remmelink, G., K. Blanken, J. van Middelkoop, W. Ouweltjes en H. van Wemmenhove, 2010. Handboek Melkveehouderij. Wageningen UR Livestock Research. Handboek 18.

\section{Bierbostel}

\section{Gegevensformulier CoVe 95}

Adamse, P., J.J.M. Driessen, J. de Jong, A. van Polanen, H.J. van Egmond en A.W. Jongbloed, 2009. Trendanalyse zware metalen in diervoeder(grondstoffen). RIKILT - Instituut voor Voedselveiligheid, Wageningen Universiteit \& Research Centre, Rapport 2009.019.CVB (2010) Tabellenboek Veevoeding 2010.

Centraal Veevoederbureau, 2010. Tabellenboek Veevoeding 2010. Lelystad.

FNR, 2006. Handreichung Biogaswinnung und -nutzung. Fachagentur Nachwachsende Rohstoffen e.V. 3., überarbeitete Auflage, Gülzow.

Klages, S., U. Schultheiß en H. Döhler, 2009. Potenzial und Eignung von Reststoffen zur Vergärung in Biogasanlagen. Landtechnik 6: 398-402.

Kool, A. en G.J. Kosman, 2003. Zware metalen op De Marke. CLM. Rapport 33.

Koppejan, J., W. Elbersen, M. Meeuwsen en P. Bindraban, 2009. Beschikbaarheid van Nederlandse biomassa voor electriciteit. Procede Biomass B.V. In opdracht van SenterNovem, november 2009, projectnummer 200809.

Sauvant, D., J.M. Perez en G. Tran, 2004. Tables of composition and nutritional value of feed materials. Wageningen academic publishers, NL \& INRA, Parijs FR. ISBN 978-90-76998-41-1.

Stoop, M.L.M., 1990. Het gebruik van natte (industriële) bijproducten in de Varkenshouderij; Een verkenning van de Nederlandse situatie. Report EUT/BDK/43. ISBN 90-6757-047-8. 
Umweltbundesamt, 2004. Erfassung von Schwermetallströmen in landwirtschaftlichen

Tierproduktionsbetrieben und Erarbeitung einer Konzeption zur Verringerung der Schwermetalleinträge durch Wirtschaftsdünger tierischer Herkunft in Agrarökosysteme. Texte 06/04. Umweltforschungsplan des Bundesministeriums für Umwelt, Naturschutz und Reactorsicherheit. Forsuchungsbericht 29972104. UBA-FB 000580. ISSN 0722-186X.

\section{Maïsgluten}

Aslaksen, M.Aa., O.F. Kraugerud, M. Penn, B. Svihus, V. Denstadli, H.Y. Jørgensen, M. Hillestad, A. Krogdahl en T. Storebakken, 2007. Screening of nutrient digestabilities and intestinal pathologies in Atlantic salmon, Salmo salar, fed diets with legumes, oilseeds, or cereals. Aquaculture 272: 541-555

Castaing, J., R. Coudure, J. Fekete en F. Grosjean, 1990. Utilisation du corn gluten feed par le porcelet sevré et le porc charcutier. Journées Rech. Porcine en France 22: 159-166.

Gonzalvez, G.S., L.E. Pezzeta, M.M. Barros, G.K. Kleeman en D.F. Rocha, 2005. Effects of Phytase supplementation on apparent availability of $\mathrm{Mg}, \mathrm{Ca}, \mathrm{Zn}, \mathrm{Cu}, \mathrm{Mn}$, an Fe of plant feedstuffs for Nile tilapia. R. Bras. Zootec., v.34, n.6, p.2155-2163.

Peter, C.M. en D.H. Baker, 2002. Bioavailability of phosphorus in corn gluten feed derived from conventional and low-phytate maize. Animal Feed Science and Technology 95: 63-71.

Sauvant, D., J.M. Perez en G. Tran, 2004. Tables of composition and nutritional value of feed materials. Wageningen academic publishers, NL \& INRA, Parijs FR. ISBN 978-90-76998-41-1.

Sevenster, M.N., 2007. Energiegebruik in de veevoerketen : Inventarisatie t.b.v. MJA2. Delft, CE. Publicatienummer: 07.6136.01

\section{Melasse}

Centraal Veevoederbureau, 2010. Tabellenboek Veevoeding 2010. Lelystad.

Casas Cardoso, L., G. Cardos Romero, M. Vales Almodovar en F. Igelesias Jacomino, 2002. Determination of mercury traces in organic sugar and final molasses. Centro Azucar 29 (4): 9-13.

Broeze, J., P. Hoeksma, H. Willers en W. Corré, 2005. De waarde van digestaat van co-vergisting ten opzichte van dierlijke mest. WUR Agrotechnology and Food Innovations, Rapport 411.

Bruins, W.J. en J. Zonderland, 1989. Invloed van het toevoegen van melasse aan gras. PR-rapport 121.

Koskamp, G.J. en M. van Kuik, 1999. Zware metalen op De Marke. Interne notitie CLM, Utrecht.

Pruijn, M., E. ten Brummeler, E. Temminghoff, B.M.L. Gerards en G. Janssen, 2003. In-situ metaalprecipitatie. Beheersing van mobiele zinkverontreiniging in de bodem met behulp van ISMP. Stichting Kennisontwikkeling Kennisoverdracht Bodem (SKB).

Sauvant, D., J.M. Perez en G. Tran, 2004. Tables of composition and nutritional value of feed materials. Wageningen academic publishers, NL \& INRA, Parijs FR. ISBN 978-90-76998-41-1.

Skrbic, B., en N. Urisic-Mladenovic, 2007. Non-dioxine-like PCB's in crops and related products: levels and intakes in Serbia. Food additives and contaminants 24(6): 652-662.

Van der Poel, P.W., H. Schiweck en T. Schwartz, 1998. Sugar technology; Beet and Sugar Cane manufacture. Verlag Dr. Albert Bartens KG. Berlijn.

Van Dijk, B., 2008. Onderzoek in de Gentse kanaalzone Onderzoek naar mogelijkheden tot uitwisseling en valorisatie. http://www.dbt.ugent.be/pdf/reststromen_eindpublicatie.pdf

\section{Raapzaadschroot}

Adamse, P., J.J.M. Driessen, J. de Jong, A. van Polanen, H.J. van Egmond en A.W. Jongbloed, 2009. Trendanalyse zware metalen in diervoeder(grondstoffen). RIKILT - Instituut voor Voedselveiligheid, Wageningen Universiteit \& Research Centre, Rapport 2009.019.

Aslaksen, M.A., O.F. Kraugerud, M. Penn, B. Svihus, V. Denstadli, H.Y. Jørgensen, M. Hillestad, A. Krogdahl en T. Storebakken, 2007. Screening of nutrient digestabilities and intestinal pathologies in Atlantic salmon, Salmo salar, fed diets with legumes, oilseeds, or cereals. Aquaculture 272: 541-555. 
Cessna, A.J., A.L. Darwent, L. Townley-Smith, K.N. Harker en K.J. Kirkland, 2000. Residues of glyphosate and its metabolite AMPA in canola seed following preharvest applications. Canadian Journal of Plant Science, 80(2): 425-431.

Centraal Veevoederbureau, 2010. Tabellenboek Veevoeding 2010. Lelystad.

Elson, C.M., Hynes, D.L. en P.A., MacNeil, 1979. Trace Metal Content of Rapeseed Meals, Oils and Seeds. Journal of the American Oil Chemists' Society, 56 (12), 998-999, DOI: 10.1007/BF02674152.

Dauguet, S., F. Fleurat-Lessard en J. Loison, 2010. Cross contimination of oilseeds by insecticedes during storage.10th International working conference on stored product protection. Julius Kuhn archiv. 425: 827-832.

FNR, 2006. Handreichung Biogaswinnung und -nutzung. Fachagentur Nachwachsende Rohstoffen e.V. 3., überarbeitete Auflage, Gülzow.

Kool, A., M. Timmerman M, H. de Boer H, J.H. van Dooren, B. van Dun, , M. Tijmensen, 2005. Kennisbundeling co-vergisting. CLM rapport 621. Senter Novem, ISBN 90-5634-196-0.

Knappe, F., S. Möhler, A. Ostermayer, S. Lazar en C. Kaufmann, 2008. Vergleichende Auswertung von Stoffeinträgen in Böden über verschiedene Eintragspfade. Dessau-Roßlau, Umweltbundesamt.

Kühnen, V. en H.E. Goldbach, 2004. Schwermetallbilanzen verschiedener Betriebstypen: Eintragswege, Flüsse, Minderungspotential. Forschungsbericht 118, Institut für Pflanzenernährung, Bonn.

Miller, N., H.E. Pretorius en L.J. Du Toit, 1986. Phytic acid in sunflower seeds, pressed cake and protein concentrate. Food Chemistry 21: 205-209.

Tys J., R. Rybacki en P. Malczyk, 2003. Sources for contamination of rapeseed with benzo(a)pyrene. Int. Agrophysics 17:131-135.

Umweltbundesamt, 2004. Erfassung von Schwermetallströmen in landwirtschaftlichen Tierproduktionsbetrieben und Erarbeitung einer Konzeption zur Verringerung der Schwermetalleinträge durch Wirtschaftsdünger tierischer Herkunft in Agrarökosysteme. Texte 06/04. Umweltforschungsplan des Bundesministeriums für Umwelt, Naturschutz und Reactorsicherheit. Forsuchungsbericht 29972104. UBA-FB 000580. ISSN 0722-186X.

\section{Perspulp van cichoreiwortels}

Centraal Veevoederbureau, 2010. Tabellenboek Veevoeding 2010. Lelystad.

Duynie Holding B.V., 2011. Informatie ter ondersteuning van het verzoek tot aanwijzing van cigarant als covergistingsmateriaal, 26 november 2010.

Juśkiewicz, J., I. Głązka, B. Król en Z. Zduńczyk, 2006. Effect of chicory products with different inulin content on rat caecum physiology. Journal of Animal Physiology and Animal Nutrition 90: 200-207.

Klop, A. , G.J. Remmelink en K.M. van Houwelingen, 2003. Cigarant $®$ als krachtvoervervanger in een graskuilrantsoen voor melkvee. Animal Sciences Group, divisie Praktijkonderzoek. PraktijkRapport Rundvee 38.

Poniedziałek, M., A. Sękara, J. Ciura en E. Jędrszczyk, 2005. Nickel and manganese accumulation and distribution in organs of nine crops. Folia Horticulturae 17/1: 11-22.

\section{Wei}

Gegevensformulier CoVe 11

Gegevensformulier CoVe 15

Gegevensformulier CoVe 17

Gegevensformulier CoVe 18

Adamse, P., J.J.M. Driessen, J. de Jong, A. van Polanen, H.J. van Egmond en A.W. Jongbloed, 2009. Trendanalyse zware metalen in diervoeder(grondstoffen). RIKILT - Instituut voor Voedselveiligheid, Wageningen Universiteit \& Research Centre, Rapport 2009.019. 
Josephson, R.V., S.S.H. Rizvi en W.J. Harper, 1975. Compositional differences in whey systems. Journal of Food Science 40: 479-483.

Sauvant, D., J.M. Perez en G. Tran, 2004. Tables of composition and nutritional value of feed materials. Wageningen academic publishers, NL \& INRA, Parijs FR. ISBN 978-90-76998-41-1.

\section{Voedingsmiddelenslib}

Gegevensformulier CoVe 90

Gegevensformulier CoVe 105

Aarnink, A., K. de Greef, T. Hermans, H. Langeveld, R. Leopold en J. Luttik, 2000. Functieanalyse diersystemen nu en in 2040. Werkgroep functieanalyse. Wageningen/Lelystad. http://edepot.wur.nl/116324.

FNR, 2006. Handreichung Biogaswinnung und -nutzung. Fachagentur Nachwachsende Rohstoffen e.V. 3., überarbeitete Auflage, Gülzow.

\section{Bloembollenreststoffen}

Gegevensformulier CoVe 102

Belder, P, 2011a. Toelatingsonderzoek restmaterialen bollenteelt voor co-vergisting. Praktijkonderzoek Plant \& Omgeving B.V. Bloembollen, Boomkwekerij en Fruit. Januari 2011. PPO nr. 3236083800 PT 13636.

Belder, P, 2011b. Beantwoording noodzakelijke informatie voor toetsing restmateriaal bloembollenteelt en broei als covergistingsmateriaal. Notitie van Praktijkonderzoek Plant \& Omgeving B.V. Bloembollen, Boomkwekerij en Fruit.

Bondt, N., B. Janssens en A. de Smet, 2010. Afval uit de landbouw. LEI. LEI-nota 10-061. Projectcode 32066. Wageningen UR. Den Haag.

\section{Glycerine van dierlijke herkomst}

Gegevensformulier CoVe 107.

Aalten, M, J. de Vries en J.C.M.M. van den Akker, 2003. Een oriënterend onderzoek op chemische contaminanten in diervoedervetten. VWA/Keuringsdienst van Waren Oost. Projectnummer LotOVET001.

Creamer K.S., Y. Chen, C.M. Williams en J.J. Cheng, 2010. Stable thermophilic anaerobic digestion of dissolved air flotation (DAF) sludge by co-digestion with swine manure. Bioresource Technology 101 : 3020-3024.

Falk, O, H. Wichmann, P. Jopke, Ch. Schimdt-Nädler, B. Matthies, M. Bahadir en R. Meyer-Pittroff, 2004. Verbleib von Spurenschadstoffen bei der Methylesterherstellung aus Altspeisefett im Technikumsmasssab. Z. Umweltchem. Ökotox 16(4) : 255-261.

Luske, B., en H. Blonk, 2009. Milieueffecten van dierlijke bijproducten. Blonk Milieuadvies BV. Gouda. http://www.blonkmilieuadvies.nl/nl/pdf/pbl_bijproducten_eindrapport.pdf.

Hilten, R., R. Speir, J. Kastner en K.C. Das, 2010. Production of fuel from the catalytic cracking of pyrolyzed poultry DAF skimmings. Journal of Analytical and Applied Pyrolysis 88: 30-38.

Nebel, B.A. en M. Mittelbach, 2006. Biodiesel from extracted fat out of meat and bone meal. Eur. J. Lipid Sci. Technol. 108: 398-403.

Smith, J., M. Garcia-Perez en K.C. Das, 2009. Producing fuel and specialty chemicals from the slow pyrolysis of poultry DAF skimmings. J. Anal. Appl. Pyrolysis 86: 115-121.

\section{Graanresten}

Gegevensformulier CoVe 111

Gegevensformulier CoVe 112

Gegevensformulier CoVe 115 
Centraal Veevoederbureau, 2010. Tabellenboek Veevoeding 2010. Lelystad.

FNR, 2006. Handreichung Biogaswinnung und -nutzung. Fachagentur Nachwachsende Rohstoffen e.V. 3., überarbeitete Auflage, Gülzow.

Umweltbundesamt, 2004. Erfassung von Schwermetallströmen in landwirtschaftlichen Tierproduktionsbetrieben und Erarbeitung einer Konzeption zur Verringerung der Schwermetalleinträge durch Wirtschaftsdünger tierischer Herkunft in Agrarökosysteme. Texte 06/04. Umweltforschungsplan des Bundesministeriums für Umwelt, Naturschutz und Reactorsicherheit. Forsuchungsbericht 29972104. UBA-FB 000580. ISSN 0722-186X.

Sauvant, D., J.M. Perez en G. Tran, 2004. Tables of composition and nutritional value of feed materials. Wageningen academic publishers, NL \& INRA, Parijs FR. ISBN 978-90-76998-41-1.

\section{Koffiedik}

Schaap, I., 2010. Dossier Koffiedik. Schaap bio-industrie, 9-12-2010. Ingediend op 15-12-2011

Oldenhuis, R., 2011. Analyserapport, versie 2. Co-vergistingsmateriaal Schaap Bioindustrie. HoST bioenergy installations. 2776rap01_2, 19-04-2011 met 2 bijlagen.

Froehner, S., W. Piccioni, K. Scurupa Machado en M.M. Mansur Aisse, 2011. Removal Capacity of Caffeine, Hormones, and Bisphenol by Aerobic and Anaerobic Sewage Treatment. Water Air Soil Pollution, 216:463-471. DOI 10.1007/s11270-010-0545-3.

\section{Bietenperspulp}

Adamse, P., J.J.M. Driessen, J. de Jong, A. van Polanen, H.J. van Egmond en A.W. Jongbloed, 2009. Trendanalyse zware metalen in diervoeder(grondstoffen). RIKILT - Instituut voor Voedselveiligheid, Wageningen Universiteit \& Research Centre, Rapport 2009.019.

Duynie Holding B.V., 2011. Informatie ter ondersteuning van het verzoek tot aanwijzing van bienteperspulp als covergistingsmateriaal, 26 november 2010.

FNR, 2006. Handreichung Biogaswinnung und -nutzung. Fachagentur Nachwachsende Rohstoffen e.V. 3., überarbeitete Auflage, Gülzow.

Umweltbundesamt, 2004. Erfassung von Schwermetallströmen in landwirtschaftlichen Tierproduktionsbetrieben und Erarbeitung einer Konzeption zur Verringerung der Schwermetalleinträge durch Wirtschaftsdünger tierischer Herkunft in Agrarökosysteme. Texte 06/04. Umweltforschungsplan des Bundesministeriums für Umwelt, Naturschutz und Reactorsicherheit. Forsuchungsbericht 29972104. UBA-FB 000580. ISSN 0722-186X.

Remmelink, G., K. Blanken, J. van Middelkoop, W. Ouweltjes en H. van Wemmenhove, 2010. Handboek Melkveehouderij. Wageningen UR Livestock Research. Handboek 18.

Rogers, P., 2000. Chemical composition of common wet en dry feedstuffs. Composition (dry matter, energy, protein, ash, major- and trace-elements) of common feedstuff. Grange Research Centre, Dunsany, Co. Meath, Ireland.

Sauvant, D., J.M. Perez en G. Tran, 2004. Tables of composition and nutritional value of feed materials. Wageningen academic publishers, NL \& INRA, Parijs FR. ISBN 978-90-76998-41-1.

\section{Aardappelstoomschillen}

Gegevensformulier CoVe 37

Verzoek CDM 32.

Koppejan, J., W. Elbersen, M. Meeuwsen en P. Bindraban, 2009. Beschikbaarheid van Nederlandse biomassa voor electriciteit. Procede Biomass B.V. In opdracht van SenterNovem, november 2009, projectnummer 200809. 


\section{Stillage}

Gegevensformulier CoVe 114.

Verzoek CDM 47.

Adamse, P., J.J.M. Driessen, J. de Jong, A. van Polanen, H.J. van Egmond en A.W. Jongbloed, 2009. Trendanalyse zware metalen in diervoeder(grondstoffen). RIKILT - Instituut voor Voedselveiligheid, Wageningen Universiteit \& Research Centre, Rapport 2009.019.

FNR, 2006. Handreichung Biogaswinnung und -nutzung. Fachagentur Nachwachsende Rohstoffen e.V. 3., überarbeitete Auflage, Gülzow.

Klages, S., U. Schultheiß en H. Döhler, 2009. Potenzial und Eignung von Reststoffen zur Vergärung in Biogasanlagen. Landtechnik 6: 398-402.

Sauvant, D., J.M. Perez en G. Tran, 2004. Tables of composition and nutritional value of feed materials. Wageningen academic publishers, NL \& INRA, Parijs FR. ISBN 978-90-76998-41-1. 


\section{Bijlage 5 Bepaling van de geschatte en de maximaal toelaatbare vracht aan residuen van gewasbeschermingsmiddelen in covergistingsmaterialen en digestaat}

Eerste opzet voor een methodiek ter ondersteuning van expert-judgement

\section{Inleiding}

Er bestaat een zogenoemde Positieve Lijst (2010) met covergistingsmaterialen waarin gewassen, gewasproducten en omschrijvingen van rest- en afvalstoffen zijn opgenomen. Alleen covergistingsmaterialen ("stoffen") waarvan is komen vast te staan dat er geen landbouwkundige of milieukundige bezwaren bestaan, worden toegevoegd aan deze positieve lijst. De beoordeling daarvan geschiedt door de Werkgroep Toetsing Stoffen van de onafhankelijke Commissie van Deskundigen Meststoffenwet (CDM) aan de hand van het protocol Beoordeling Stoffen Meststoffenwet versie 2.1 (Van Dijk et al., 2009). Veel verzoeken tot plaatsing van potentiële co-vergistingsmaterialen op de positieve lijst leiden tot een negatief oordeel door de aanwezigheid van residuen van niet-regulier beoordeelde organische stoffen ("Overige organische micro-verontreinigingen"). Hieronder vallen de residuen van gewasbeschermingsmiddelen en biociden. Voor de sector leidt dit tot een knelpunt bij de beschikbaarheid van covergistingsmaterialen voor vergisting met dierlijke mest.

De huidige systematiek is een waarborg tegen onverantwoorde belasting van landbouwgronden met, voor het milieu, risicovolle stoffen die in bepaalde co-vergistingsmaterialen aanwezig kunnen zijn. Dit project beoogt expert-judgement te ondersteunen bij de beoordeling van werkzame stoffen van gewasbeschermingsmiddelen in gewassen, waarvan de rest- of afvalstromen in aanmerking kunnen komen om mede vergist te worden met dierlijke mest. Een eventueel gewijzigde methodiek moet leiden tot een beoordelingsmethode voor gewasbeschermingsmiddelen en biociden, waarbij eveneens de bestaande toelating van die stoffen in ogenschouw genomen wordt. Vooruitlopend op een eventuele wijziging van de systematiek hebben LTO-Nederland (Land- en Tuinbouw Organisatie Nederland) en de Biogas Brancheorganisatie 21 covergistingsmaterialen geïnventariseerd ("LTO-lijst"). Omdat het wenselijk is om deze stoffen op de positieve lijst te plaatsen, probeert de CDM de beoordeling van deze stoffen uiterlijk in 2011 te hebben afgerond. Daarna kan worden besloten welke van deze co-vergistingsmaterialen aan de positieve lijst worden toegevoegd. De LTO/BBO-lijst werd uitgebreid tot 27 stoffen door toevoeging van 6 stoffen door het ministerie van EL\&I. Het RIVM heeft hiertoe een eerste aanzet voor een beoordeling uitgewerkt, waarbij - zo nodig - gebruik gemaakt wordt van expert-judgement.

\section{Werkzame stoffen in de LTO-lijst van $\mathbf{2 7}$ co-vergistingsmaterialen: selectie en prioritering} Om tot een hanteerbare lijst van werkzame stoffen te komen, is er een tiental werkzame stoffen geselecteerd die in Nederland zijn toegelaten en die kunnen voorkomen in co-vergistingsmaterialen. Om dit selectieproces helder en objectief te kunnen uitvoeren zijn er criteria geformuleerd die gebaseerd zijn op relevantie van toepassing van deze werkzame middelen en het risico van belasting van Nederlandse landbouwbodem door residuen. Op basis van deze criteria zijn de werkzame stoffen naar prioriteit gerangschikt, waarbij de bovenste tien actieve stoffen geselecteerd werden. Na het covergistingsproces worden de residuen van werkzame stoffen verondersteld aanwezig te zijn in het digestaat, dat vervolgens langjarig wordt toegepast als meststof. 


\section{Relevantie voor de 27 co-vergistingsmaterialen}

Uit de veelheid aan gegevens over de in gewasbeschermingsmiddelen (GBM) aanwezige werkzame stoffen die zijn toegelaten in Nederland, werden die werkzame stoffen gefilterd die in de covergistingsmaterialen zouden kunnen voorkomen. Op aanvraag werden de volgende EXCEL-bestanden door de Gewasbeschermingskennisbank (GBK, 2010) verstrekt:

- Werkzame stoffen in diverse gewassen.xls

- Middelen ruimtebehandeling gesloten bewaarplaats.xls

- Toegelaten_middelen_erwten_bieten_cichorei.xls

- Werkzame stoffen in bloembollen.xls

Deze bestanden bevatten de werkzame middelen in toegelaten GBM's die in Nederland worden toegepast in mogelijk relevante gewassen. Daaruit werden de gewassen geselecteerd die een rol kunnen spelen als co-vergistingsmaterialen die in de LTO-lijst voorkomen. Omdat ook na deze filtering er nog sprake was van een te groot aantal verschillende gewassen, volgde een aggregatiestap tot 10 categorieën:

- Bieten;

- Bloembollen;

- Cichorei;

- Consumptieaardappelen;

- Fabrieksaardappelen;

- Graan;

- Gras;

- Maïs;

- Uien;

- Erwten.

Het aantal werkzame stoffen dat wordt toegepast ter bescherming van deze categorieën is groot. Uit de verzameling van werkzame stoffen die in de co-vergistingsmaterialen kunnen voorkomen, werd op basis van toepassingsfrequentie een lijst opgesteld. Deze stap was nodig voor het opstellen van een shortlist van ca. 50 werkzame stoffen. Bijlage 5.1 bevat deze shortlist.

De criteria voor het selecteren van tien werkzame stoffen

Bij de emissie van milieuverontreinigende stoffen wordt dikwijls onderscheid gemaakt tussen diffuse bronnen en puntbronnen. De frequentie van voorkomen in de bestanden van het CBS (criterium 1) geeft een indruk van de mate waarin emissie naar landbouwbodem afkomstig is van diffuse bronnen. Diffuse belasting wordt in deze prioriteringmethodiek als bezwaarlijker gewaardeerd dan puntbronnen. De maximaal toelaatbare vracht (criterium 2) is gebaseerd op het risicoconcept dat wordt toegepast bij de beoordeling van chemische stoffen waaraan ecosystemen en dus ook landbouwgronden worden blootgesteld. Daarbij worden fictieve, maximaal toelaatbare of mogelijke blootstellingsconcentraties vergeleken met concentraties die effect (kunnen) hebben op het milieu. Deze effectconcentraties worden afgeleid uit laboratoriumtoetsen met relevante organismen die kunnen voorkomen in bodem en water. Het gaat hierbij om algemene milieukwaliteit waarbij landbouwbodem als een terrestrisch ecosysteem wordt opgevat. Het quotiënt van het jaarlijkse gebruiksvolume in Nederland en de maximale vracht (3) is een indicatie voor de milieugebruiksruimte van een chemische stof. Het is de verhouding tussen emissie en risico en geeft het aantal hectaren dat met een actieve stof wordt opgevuld tot een bepaalde kritische grens.

De shortlist van ca. 50 stoffen was de basis voor de uiteindelijke selectie. De werkzame stoffen werden gesorteerd naar:

1. Afnemende frequentie van voorkomen,

2. Toenemende maximale vracht ( $g / h a)$,

3. Afnemend quotiënt van het jaarlijkse gebruiksvolume $(\mathrm{kg})$ in Nederland en de maximale vracht (g/ha).

De frequentie werd bepaald door na te gaan hoe vaak een werkzame stof in de GBK-bestanden voorkomt in toegelaten middelen om bovengenoemde gewascategorieën te beschermen. De werkzame stoffen werden voorzien van gegevens over toepassingsvolume. Hiervoor werden data van het 
Centraal Bureau voor de Statistiek (CBS, 2010) verzameld over het gebruik van de werkzame stof in $\mathrm{kg}$ per jaar in Nederland in 2008. Tabel B5.1 geeft de data voor de werkzame stoffen die uiteindelijk geselecteerd werden ${ }^{79}$.

\section{Tabel B5.1}

Gegevens van de werkzame stoffen geprioriteerd uit de shortlist. Subscript $w$ en sb hebben betrekking op water, respectievelijk standaardbodem. AMPA is een metaboliet van glyfosaat met $K_{p} A M P A=284$ $\mathrm{L} / \mathrm{kg}\left(K_{p}\right.$ glyfosat $\left.=740 \mathrm{~L} / \mathrm{kg}\right) . N B: V R$-waarde betreft hier de concentratie voor landbouwbodem.

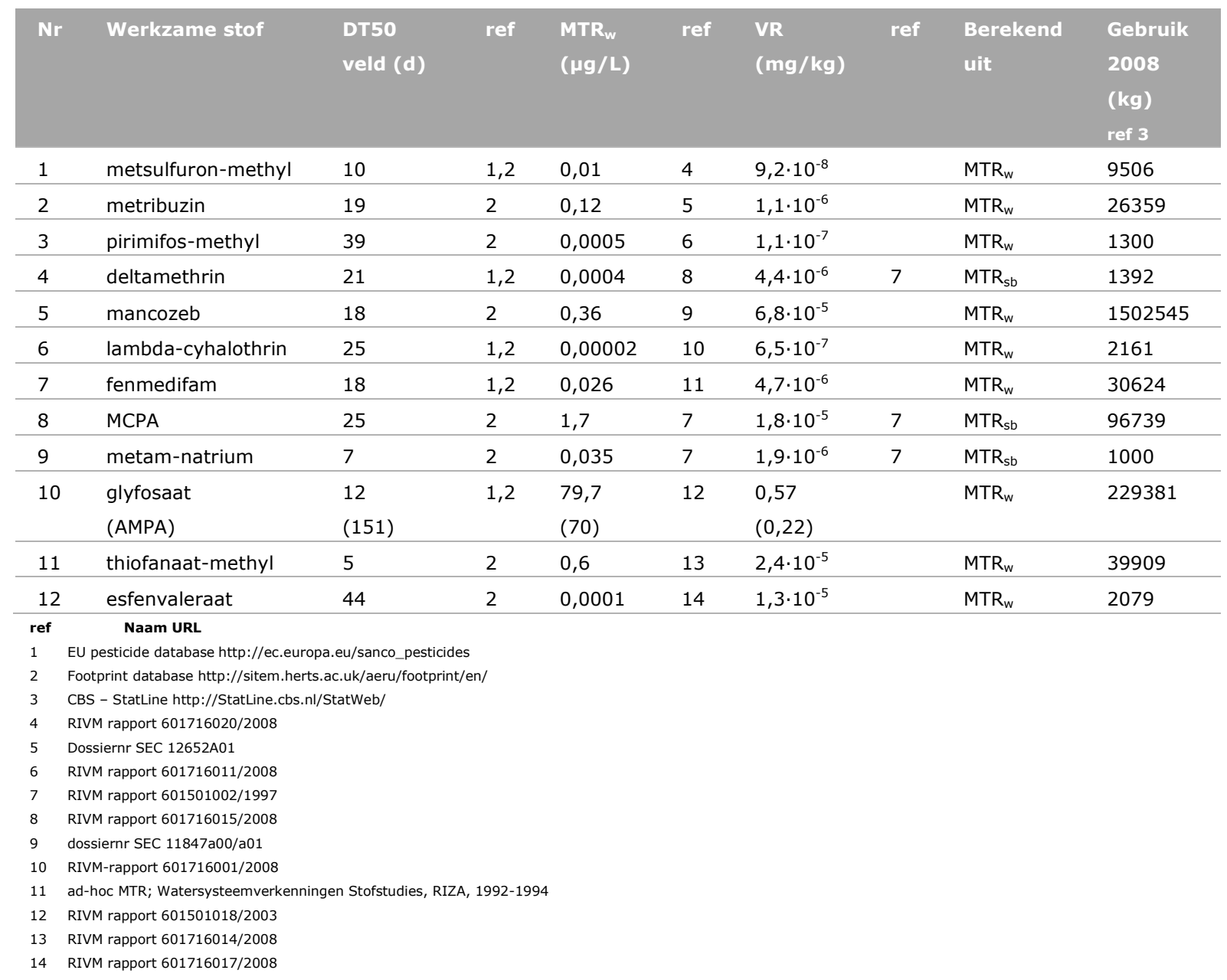

Het risico van een werkzame stof voor de landbouwbodem werd gekarakteriseerd als de maximale vracht ( $\mathrm{g} / \mathrm{ha}$ ) die jaarlijks mag worden aangebracht. De maximale vracht, berekend volgens het Protocol 2.1 (Van Dijk et al., 2009) is een typisch risicoconcept waarin de concentratie van een actieve stof, homogeen verdeeld over de bovenste 20 centimeter van landbouwgrond, wordt afgeleid op basis van een jaarlijkse pulsemissie gevolgd door aërobe afbraak met een bekende halfwaardetijd. Door accumulatie stijgt de concentratie na toedieningen in opeenvolgende jaren tot een plateau dat vergeleken wordt met die van het verwaarloosbare risiconiveau (VR) dat $1 \%$ van het Maximaal Toelaatbare Risico (MTR) bedraagt. In het protocol wordt geen rekening gehouden met het feit dat de bodem daarnaast ook gelijktijdig met residuen van dezelfde gewasbeschermingsmiddelen uit een andere bron kan worden belast.

Vooralsnog werden de meeste waarden voor VR ${ }^{80}$ afgeleid uit MTR water (in Tabel B5.1 weergegeven als $M T R_{w}$ ). Hiervoor werd de evenwichtspartitiemethode toegepast. De water-sediment

\footnotetext{
${ }^{79}$ Aanvankelijk is een selectie van 10 actieve stoffen gemaakt. Bij een nadere analyse van onderliggende gegevens voor een aantal van deze stoffen bleek een aanpassing noodzakelijk, waardoor een herziene lijst is verkregen. Twee actieve stoffen die tot de selectie van de eerste lijst van 10 behoorden, zijn echter in deze notitie gehandhaafd met volgnummer 11 en 12. Dit volgnummer geeft echter niet hun rangschikking weer op de totale lijst van 50 actieve stoffen.
} 
partitiecoëfficiënt $\left(K_{p}\right)$ werd afgeleid uit de $K_{\text {ow }}$ waarde (octanol-water partitiecoëfficiënt) van de betreffende actieve stof en het koolstofgehalte van sediment. Vervolgens werd de MTR standaardbodem $\left(M T R_{s b}\right.$ ) verkregen door MTR water te vermenigvuldigen met deze partitiecoëfficiënt. VR $R_{s b}$ werd gelijk gesteld aan $M_{T R} / 100$. De waarden voor landbouwbodem werden verkregen door vermenigvuldiging met de factor 0,34 ( $=2 / 5,88$ de verhouding organisch koolstof gehalte in standaardbodem en landbouwbodem).

De in deze notitie weergegeven niveaus van MTR of VR voor bodem zijn voor een deel indicatieve getallen (Tabel B5.1). Daar waar wetenschappelijke en/of beleidsmatig vastgestelde MTR- of VRwaarden voor bodem konden worden achterhaald, zijn deze gebruikt voor de analyse. Bij ontbreken ervan zijn deze geraamd op basis van aquatische toxiciteitsgegevens. Er is hierbij - wegens tijdsgebrek - geen nadere analyse gedaan of toxiciteitsgegevens voor bodemorganismen zouden leiden tot een andere indicatieve waarde voor MTR of VR voor bodem ${ }^{81}$.

\section{Rangschikking}

Het resultaat van de sortering van de lijst met 50 werkzame stoffen volgens afnemende frequentie, oplopende maximale vracht en afnemend quotiënt jaarlijks gebruiksvolume in Nederland en maximale vracht wordt weergegeven in Tabel B5.2.

\section{Tabel B5.2}

De 12 geselecteerde stoffen, inclusief de score voor de drie criteria.

\begin{tabular}{|c|c|c|c|c|c|c|}
\hline $\mathbf{N r}$ & Werkzame stof & Toepassing & Frequentie & $\begin{array}{l}\text { Maximale } \\
\text { vracht }\end{array}$ & $\begin{array}{l}\text { Gebruik/ } \\
\text { max. vracht }\end{array}$ & Totaal \\
\hline 1 & metsulfuron-methyl & land & 1 & 15 & 15 & 31 \\
\hline 2 & metribuzin & land & 0 & 12 & 14 & 26 \\
\hline 3 & pirimifos-methyl & opslag & 0 & 14 & 12 & 26 \\
\hline 4 & deltamethrin & land & 13 & 10 & 0 & 23 \\
\hline 5 & mancozeb & land/opslag & 9 & 0 & 13 & 22 \\
\hline 6 & lambda-cyhalothrin & land & 0 & 13 & 8 & 21 \\
\hline 7 & fenmedifam & land & 0 & 9 & 11 & 20 \\
\hline 8 & MCPA & land & 4 & 4 & 9 & 17 \\
\hline 9 & metam-natrium & land & 5 & 11 & 0 & 16 \\
\hline 10 & glyfosaat & land & 15 & 0 & 0 & 15 \\
\hline 11 & thiofanaat-methyl & land/opslag & 0 & 2 & 5 & 7 \\
\hline 12 & esfenvaleraat & land & 0 & 7 & 0 & 7 \\
\hline
\end{tabular}

Aan de stof die bovenaan eindigde werd de score 15 toegekend en aan de stof die op de $15^{\mathrm{e}}$ plaats eindigde werd 1 toegekend. De uiteindelijke selectie kwam tot stand door een combinatie van bovengenoemde drie criteria. Voor elke stof werd de score van deze drie criteria bij elkaar opgeteld. Een stof kan op deze manier maximaal een score van 45 halen. In de lijst eindigde metsulfuronmethyl bovenaan met 31 punten, glyfosaat kwam op de tiende plaats met 15 punten.

Vervolgens werd bekeken voor welke teelten en co-vergistingsmaterialen deze werkzame stoffen van belang zijn (Tabel B5.3). Voor de beoordeling van de co-vergistingsmaterialen die een relatie hebben met de geselecteerde werkzame stoffen, zal moeten worden onderzocht hoe hoog de concentratie is in de co-vergistingsmaterialen.

\footnotetext{
${ }^{80}$ In de rest van deze notitie wordt met de getalswaarden voor VR of MTR (dus zonder subscript) de concentratie in landbouwbodem weergegeven, die is berekend uit de desbetreffende norm voor Nederlandse standaardbodem.

${ }^{81}$ Een deel van de in deze notitie weergegeven MTR- of VR-waarden zijn daarom ook niet te beschouwen/gebruiken als formele MTR- of VR-waarden, aangezien een complete formele afleiding niet heeft plaatsgevonden. Waar dus in deze notitie MTR- of VR-waarden worden vermeld, betekent dit in sommige gevallen dat het geen definitieve/formele MTR- of VR-waarden betreft, maar indicatieve waarden hiervoor.
} 
Tabel B5.3

De 12 geselecteerde werkzame stoffen, de gewascategorieën waar de stoffen voor worden gebruikt en de corresponderende co-vergistingsmaterialen.

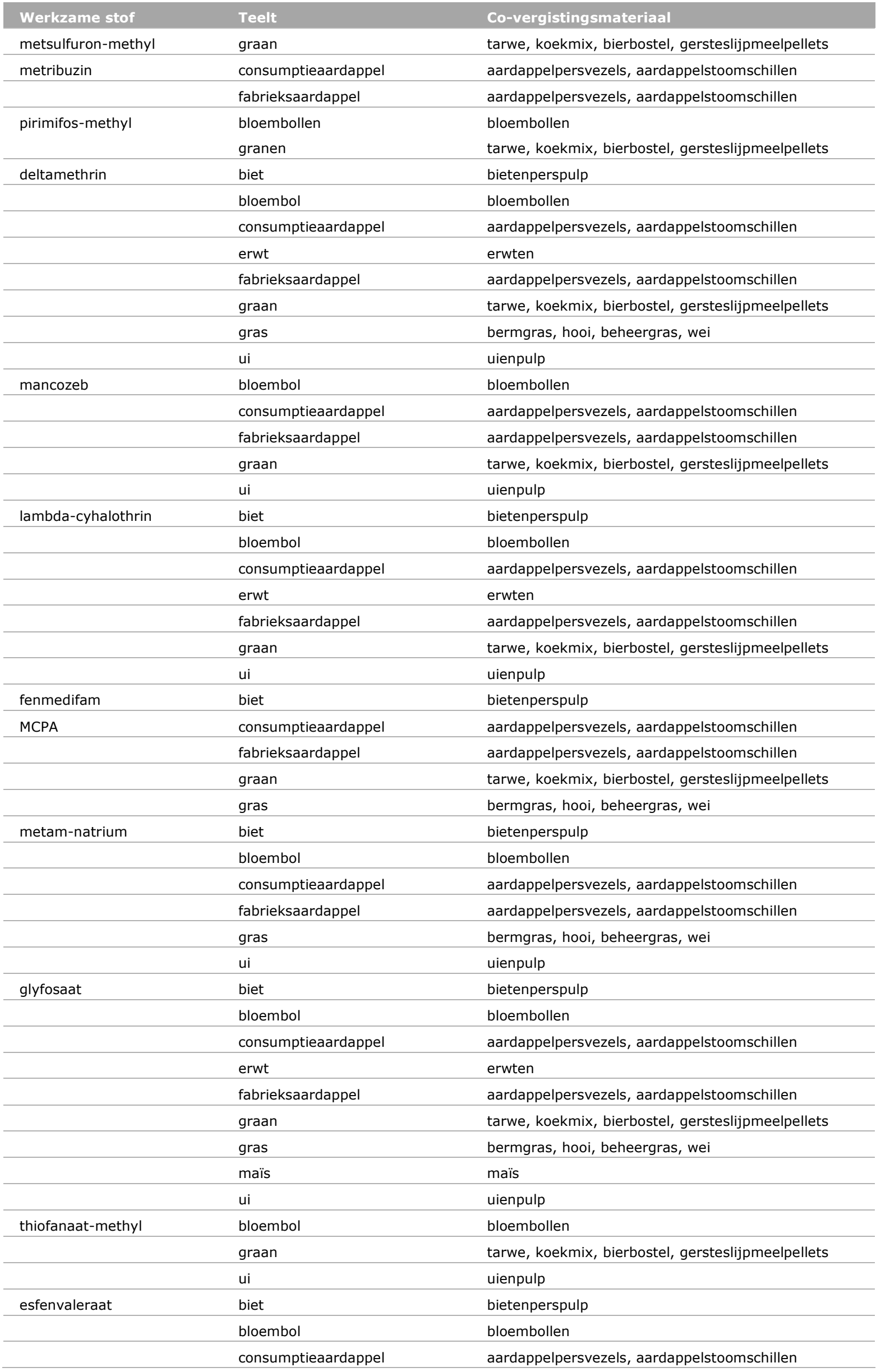




\begin{tabular}{lll} 
Werkzame stof & Teelt & Co-vergistingsmateriaal \\
& erwt & erwten \\
\hline fabrieksaardappel & aardappelpersvezels, aardappelstoomschillen \\
\hline graan & tarwe, koekmix, bierbostel, \\
\hline gras & gersteslijpmeelpellets \\
\hline ui & bermgras, hooi, beheergras, wei \\
\hline
\end{tabular}

\section{Alternatieve bepaling van de maximaal toelaatbare vracht van de geselecteerde werkzame stoffen}

De maximaal toelaatbare vracht kan berekend worden voor verschillende scenario's. De waarden in Tabel B5.4 zijn gebaseerd op DT50-waarden voor afbraak onder veldomstandigheden en VR in Tabel B5.1. De maximale vracht wordt berekend uit de maximale concentratie van een actieve stof in de landbouwbodem op tijdstip nul $\left(\mathrm{C}_{\mathrm{t}=0}\right)$. Deze concentratie is tevens gelijk aan de maximale concentratieverhoging direct na jaarlijkse digestaatgift aan de bodem. Deze (verhoging van de) concentratie is rechtevenredig met de maximale vracht van de actieve stof.

Bij langjarige jaarlijkse toepassing van digestaat kan op het moment dat dit wordt aangebracht, de concentratie van de actieve stof met een beperkte afbreekbaarheid een plateau bereiken ( $\left.C_{\max }\right)$. Ook de minimumconcentratie, het laagste niveau dat ieder jaar wordt bereikt vlak voordat het digestaat opnieuw wordt aangebracht, bereikt een plateau $\left(C_{\min }\right)$. Er geldt $C_{\max }=C_{\min }+C_{t=0}$.

De tweede kolom in Tabel B5.4 (heading $\mathrm{C}_{\max }=\mathrm{VR}$ ) geeft de maximale vracht berekend volgens het protocol, versie 2.1 (Van Dijk et al., 2009) gebaseerd op de methodiek van Olde Venterink \& Linders (1994). Deze conservatieve benadering waarbij $C_{\max }$ nooit VR zal overschrijden, dient als referentie.

In de derde kolom (heading Alternatief $1, C_{\max }=M T R$ ) is de maximale vracht hoger omdat wordt toegestaan dat bij meerjarige toediening van digestaat de concentratie een plateau mag bereiken dat gelijk is aan MTR i.p.v. VR. De maximale vracht op basis van $C_{\max }=$ MTR is dan ook een factor 100 hoger dan conform het protocol, versie 2.1 (Van Dijk et al., 2009) omdat MTR een factor 100 hoger is dan VR en omdat de maximale vracht evenredig is met de maximaal toelaatbare concentratie in de landbouwbodem. De maximale vracht op basis van $C_{\max }=$ MTR zou kunnen impliceren dat kort voor de volgende digestaatgift de concentratie in de bodem $\left(C_{\min }\right)$ hoger is dan VR en - bij hoge DT50 zelfs een aantal malen VR en in principe zelfs bijna 100 keer VR.

De vierde kolom (heading Alternatief $2, C_{\min }=V R$ en $C_{\max } \leq 10 \cdot M T R$ ) geeft de maximale vracht berekend op een wijze die principieel verschilt in de afleiding van de toegestane bodemconcentratie. In dit scenario mag op moment van de digestaatgift de bodemconcentratie - anders dan bij het eerste alternatief- hoger zijn dan MTR. Er wordt echter een additionele voorwaarde gesteld die bepaalt dat binnen een jaar - dus kort voor de volgende digestaatgift - de concentratie gedaald is naar het niveau VR. De maximale concentratie is begrensd tot tien keer MTR.

Een vergelijkbare benadering wordt gevolgd in de vijfde kolom in Tabel B5.4, gepresenteerd als Alternatief 3 (heading Alternatief $3, C_{\min }=V R$ en $C_{\max } \leq M T R$ ). Het verschil met alternatief 2 is dat de begrenzing van de bodemconcentratie is beperkt tot één keer MTR in plaats van 10 MTR.

Ter vergelijking wordt in de zesde kolom van Tabel B5.4 (heading max. vracht als GBM) voor de actieve stoffen de maximale jaardosis vermeld, waarbij de dosering volgens het toelatingsvoorschrift van de bijbehorende GBM is vermenigvuldigd met het maximaal aantal doseringen per jaar. 
Tabel B5.4

Maximale vracht voor landbouwbodem. De tweede kolom geeft de resultaten weer volgens het protocol 2.1. De derde, vierde en vijfde kolom geven de alternatieve bepalingsmethoden.

\begin{tabular}{|c|c|c|c|c|c|}
\hline \multirow[t]{4}{*}{ Werkzame stof } & \multicolumn{4}{|c|}{ Maximale vracht (g/ha) } & \multirow{4}{*}{$\begin{array}{l}\text { Max. } \\
\text { vracht } \\
\text { als GBMc } \\
(\mathrm{g} / \mathrm{ha} / \mathrm{jr})\end{array}$} \\
\hline & Protocol 2.1 & Alternatief 1 & Alternatief 2 & Alternatief 3 & \\
\hline & $\mathrm{C}_{\max }=\mathrm{VR}$ & $\mathrm{C}_{\max }=\mathrm{MTR}$ & $\mathrm{C}_{\min } \leq \mathrm{VR}$ & $\mathrm{C}_{\min } \leq \mathrm{VR}$ & \\
\hline & & & $\mathrm{C}_{\max } \leq 10 \cdot \mathrm{MTR}$ & $\mathrm{C}_{\max } \leq \mathrm{MTR}$ & \\
\hline metsulfuron-methyl & 0,0003 & 0,028 & 0,28 & 0,028 & 20 \\
\hline metribuzin & 0,0032 & 0,322 & 3,2 & 0,322 & 2100 \\
\hline pirimifos-methyl & 0,0003 & 0,033 & 0,22 & 0,033 & opslag \\
\hline deltamethrin & 0,0133 & 1,33 & 13,3 & 1,33 & $25-40$ \\
\hline \multirow[t]{2}{*}{ mancozeb } & 0,2041 & 20,4 & 204 & 20,4 & $17067-$ \\
\hline & & & & & 25600 \\
\hline lambda-cyhalothrin & 0,0019 & 0,19 & 1,9 & 0,19 & 40 \\
\hline fenmedifam & 0,0140 & 1,4 & 14 & 1,4 & 5120 \\
\hline MCPA & 0,0551 & 5,5 & 55 & 5,5 & $1333-2667$ \\
\hline \multirow[t]{2}{*}{ metam-natrium } & 0,0056 & 0,56 & 5,6 & 0,56 & $40800-$ \\
\hline & & & & & $102000^{\mathrm{a}}$ \\
\hline glyfosaat & 1700 & $1,7 \cdot 10^{5}$ & $1,7 \cdot 10^{6}(2834)$ & $1,7 \cdot 10^{5}(2834)$ & 2880 \\
\hline$\left(\mathrm{AMPA}^{\mathrm{b}}\right)$ & $(530)$ & $(53059)$ & & & \\
\hline thiofanaat-methyl & 0,071 & 7,1 & 71 & 7,1 & 3000 \\
\hline esfenvaleraat & 0,038 & 3,8 & 11,8 & 3,8 & $7-267$ \\
\hline \multicolumn{6}{|c|}{$\begin{array}{l}\text { a } \mathrm{Na} \text { toepassing van metam-natrium op een perceel mag binnen } 5 \text { jaar geen toepassing meer op hetzelfde perceel } \\
\text { plaatsvinden. }\end{array}$} \\
\hline \multicolumn{6}{|c|}{ b AMPA: metaboliet van glyfosaat; is aanvullend meegenomen in de analyse. } \\
\hline \multicolumn{6}{|c|}{$\begin{array}{l}\text { c Bron: Ctgb (2011). De weergegeven waarden betreffen de maximale jaardosis. Naast toepassing in het veld is voor } \\
\text { sommige middelen ook behandeling van het gewas na oogsten mogelijk, waardoor eveneens residuen in het co- } \\
\text { vergistingsmateriaal aanwezig kunnen zijn (bijvoorbeeld dipbehandeling van bloembollen). }\end{array}$} \\
\hline
\end{tabular}

Afhankelijk van het GBM kunnen meerdere doseringen per seizoen toegestaan zijn. Uit de gegevens in deze kolom blijkt dat bij een toepassing als GBM er in de meeste gevallen sprake is van een emissie die enkele orden van grootte hoger is dan de maximale vracht berekend volgens alternatieven 2 en 3. Bij de waarden van de jaardoseringen moet echter de kanttekening worden geplaatst dat niet de gehele dosering de bodem hoeft te bereiken (afhankelijk van aan-/afwezigheid van een gewas tijdens de toepassingen). Voor de berekening van de maximale jaardosering als GBM in deze Tabel is een afvangfactor door het gewas van 0,25 gebruikt.
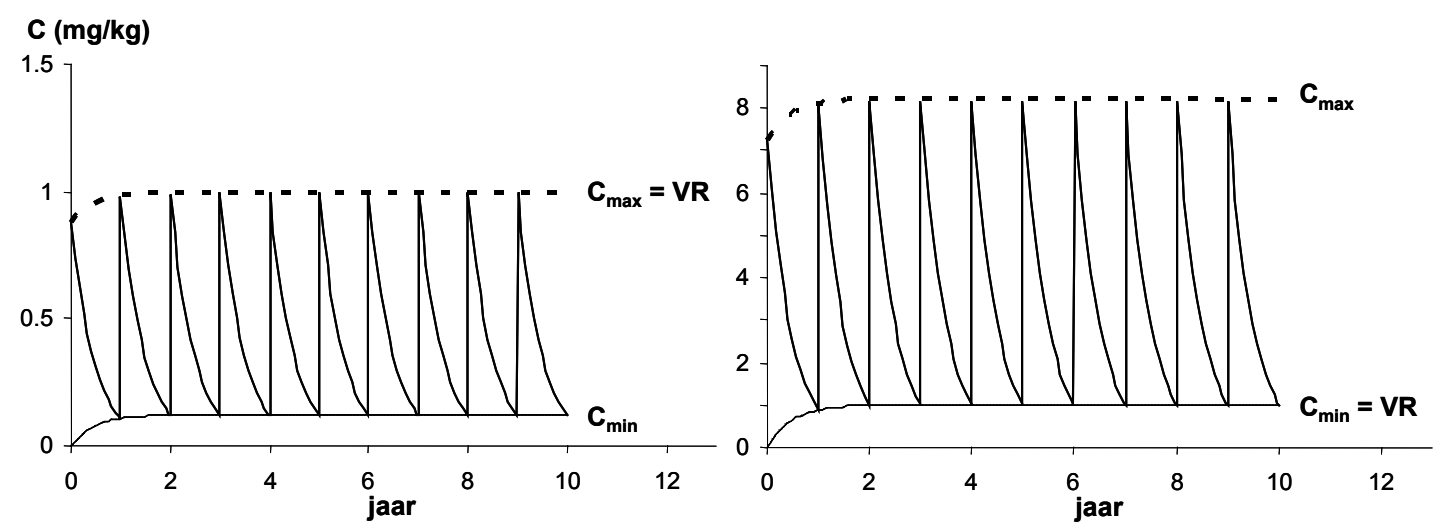

Figuur B5.1 Twee manieren om een kritische concentratie af te leiden voor een middel met $V R=1 \mathrm{mg} / \mathrm{kg}$ en DT50 = $120 \mathrm{~d}$. Het linker panel geeft de huidige procedure weer (protocol) waarin het accumulatieplateau $C_{\max }$ niet hoger mag worden dan VR. Het rechter panel geeft het scenario waarop de alternatieven 2 en 3 gebaseerd zijn. 
In Figuur B5.1 worden alternatieven 2 en 3 verduidelijkt aan de hand van een hypothetische actieve stof. In het rechter panel mag het maximale plateau $\left(C_{\max }\right)$ hoger zijn dan VR op voorwaarde dat het lage accumulatieplateau $\left(C_{\mathrm{min}}\right)$, dus na een jaar afbraak kort voor de nieuwe digestaatgift, het niveau van VR niet overschrijdt: $C_{\min } \leq$ VR. In het voorbeeld van Figuur B5.1 zou $\mathrm{C}_{\max }$ slechts een factor 8 hoger zijn dan berekend volgens het protocol, versie 2.1 (Van Dijk et al., 2009). Deze factor 8 geldt dan ook voor de maximale vracht. Voor deze hypothetische stof zou de maximale vracht dus een factor 12,5 lager uitvallen dan bij alternatief 1 . Immers, in alternatief 1 mag de digestaatgift het niveau van $\mathrm{C}_{\max }$ gelijk aan MTR veroorzaken, ongeacht het persistente karakter van de actieve stof en dus zonder de beperkende voorwaarde dat binnen een jaar afbraak moet plaatsvinden tot het niveau van VR. Accumulatie kan dan een plateau van $C_{m i n}$ veroorzaken dat aanzienlijk hoger is dan het niveau van VR. Voor een persistente werkzame stof als in dit voorbeeld (DT50 = $120 \mathrm{~d}$ ) zijn de alternatieven 2 en 3 dus aanzienlijk strenger dan alternatief 1 .

In Figuur B5.2 wordt de maximaal toelaatbare concentratietoediening op tijdstip nul ( $\mathrm{C}_{\mathrm{t}=0}$ dat gelijk is aan de concentratieverhoging door jaarlijkse giften van digestaat) van fictieve stoffen weergegeven als functie van de DT50 voor de vier scenario's:

1. Het protocol versie 2.1 (Van Dijk et al., 2009) waarin de concentratie nooit het niveau van VR zal overschrijden;

2. Alternatief 1 , waarin de concentratie in landbouwgrond nooit het niveau van MTR zal overschrijden maar waarbij voor relatief persistente werkzame stoffen de concentratie in de landbouwbodem na een jaar (kort voor de volgende digestaatgift) hoger (zelfs aanzienlijk hoger) kan zijn dan het niveau van VR;

3. Alternatief 2 , waarin de concentratie in landbouwgrond nooit het MTR niveau met meer dan een factor 10 zal overschrijden maar waarin een jaar na de digestaatgift de concentratie van de werkzame stof altijd gedaald is tot het niveau van VR.

4. Alternatief 3, waarin de concentratie in landbouwgrond nooit het MTR niveau zal overschrijden maar waarin een jaar na de digestaatgift de concentratie van de werkzame stof altijd gedaald is tot het niveau van VR.

Figuur B5.2 laat zien hoe voor persistente stoffen het tweede en derde alternatief strenger zijn dan het eerste alternatief: de maximale toegediende concentratie berekend volgens deze alternatieven benadert die volgens het protocol versie 2.1. Er is bewust voor gekozen om in Figuur B.4.2 op de verticale as de concentratie (dimensieloos) af te beelden in plaats van de maximale vracht. Deze concentratie ( $\mathrm{C}_{\mathrm{t}=0}$ in VR eenheden) ontstaat in de landbouwbodem bij de eerste digestaatgift en is tevens gelijk aan de concentratieverhoging (op $t=1,2 \ldots$ jaar) door jaarlijkse toedieningen van digestaat. Het voordeel van deze weergave is dat de concentratie $C_{t=0}$ voor de verschillende alternatieven rechtstreeks vergeleken kan worden met de beschermingsniveaus VR, MTR, of 10.MTR.

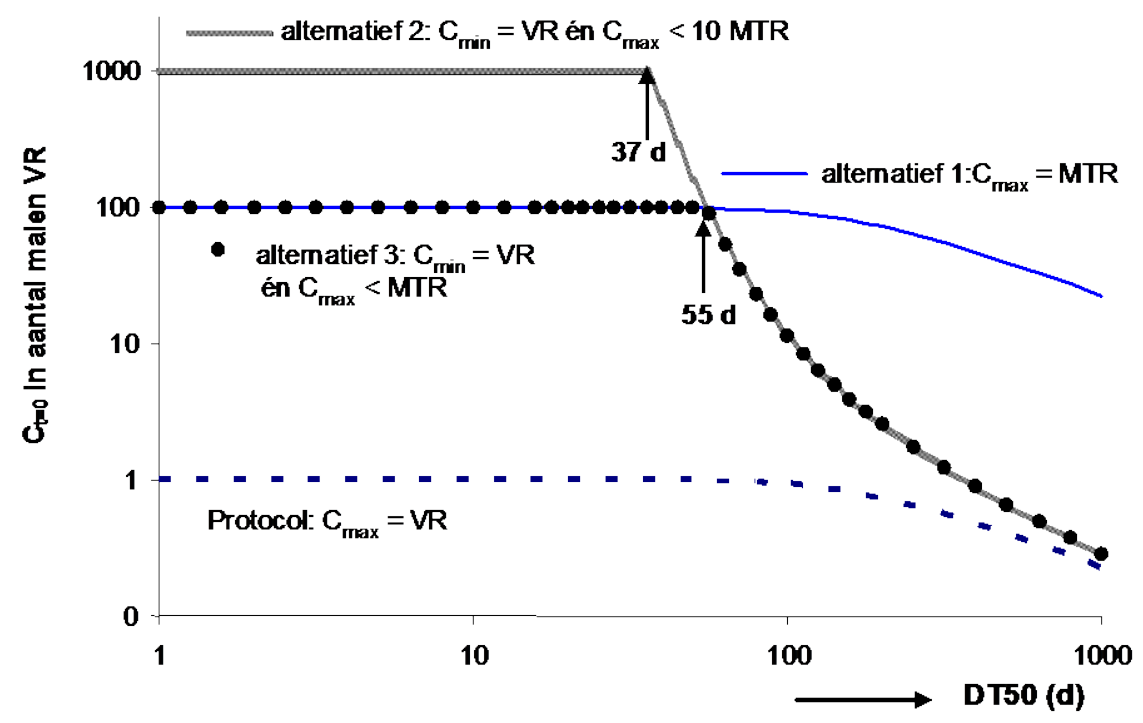

Figuur B5.2. De maximale concentratie op $t=0$ (dimensieloos geschaald naar VR) of maximale concentratieverhoging direct na jaarlijkse dosering van een werkzame stof in landbouwgrond als functie van de DT50 voor de verschillende beoordelingsvarianten. 
De maximale toegediende concentratie (gelijk aan $\mathrm{C}_{\mathrm{t}=0}$, de toegevoegde concentratie op tijdstip nul), berekend volgens alternatief 2 en 3, daalt sterk bij hogere DT50 waarden. De relevantie van "toegediende concentratie" is tweeledig: 1) om deze te kunnen vergelijken met het beschermingsniveau (VR, MTR etc.) en 2) om de maximale vracht uit te kunnen rekenen. Voor stoffen met DT50 lager dan 55 dagen is er geen verschil tussen de alternatieven 1 en 3.

Bij goed afbreekbare actieve stoffen leidt alternatief 2 tot een andere uitkomst dan volgens het protocol en alternatief 1 . Bij DT50 korter dan 37 dagen blijkt dat de maximale concentratie bij toediening meer dan een factor 100 hoger mag zijn dan VR (ofwel hoger dan MTR). Door de snelle afbraak is na één jaar de concentratie in de landbouwbodem gedaald naar VR. Zo streng als het tweede alternatieve scenario is voor persistente werkzame stoffen zo lankmoedig is het voor vlot afbreekbare werkzame stoffen. Vrijwel alle geselecteerde werkzame stoffen in deze studie bevinden zich binnen het spectrum van vlotte afbreekbaarheid.

Er kleeft echter een bezwaar aan een alternatief dat uitsluitend stipuleert dat binnen één jaar de concentratie gedaald moet zijn naar het niveau van VR. Dit wordt verduidelijkt door het volgende voorbeeld. Bij een gemakkelijk afbreekbare werkzame stof (bijvoorbeeld DT50 = $20 \mathrm{~d}$ ) zou $\mathrm{C}_{\max }$ een factor 300000 hoger mogen zijn dan VR.

Door de snelle afbraak zal de bodemconcentratie na een jaar gelijk zijn aan VR. Dit zou tot gevolg hebben dat, weliswaar zeer kortstondig, de maximale concentratie door toediening van de actieve stof het MTR niveau met een factor 3000 zou overschrijden. Omdat dit een bedreiging voor de kwaliteit van de landbouwbodem kan zijn, wordt een arbitraire begrenzing voor $C_{\max }$ voorgesteld van 10 keer MTR. Bij actieve stoffen waarvoor geldt dat DT50 $\leq 37$ dagen mag volgens alternatief $2 \mathrm{C}_{\max }$ exact een factor 10 hoger zijn dan MTR. Bij DT50 korter dan 37 dagen zou $\mathrm{C}_{\max }$ zonder deze begrenzing aanzienlijk hoger mogen zijn dan 10.MTR. De begrenzing bepaalt echter dat voor alle actieve stoffen met DT50 korter dan 37 dagen, de maximale vracht wordt gerelateerd aan een maximale concentratie bij toediening die niet hoger mag zijn dan 10.MTR. De meeste geselecteerde werkzame stoffen hebben een kortere halfwaardetijd. Alleen voor pirimifos-methyl en esfenvaleraat is, zij het marginaal, DT50 meer dan 37 dagen. Daarom geldt voor beide actieve stoffen dat om aan de voorwaarde te kunnen voldoen dat na één jaar de concentratie is gedaald naar $V R$, het niveau $C_{\max }$ niet hoger mag worden dan 6,6.MTR, respectievelijk 3,1·MTR. Voor het zeer persistente metaboliet AMPA van glyfosaat, mag $\mathrm{C}_{\max }$ zelfs niet hoger zijn dan 0,043.MTR ofwel 4,3·VR. Voor AMPA komt de maximale vracht in orde van grootte in de buurt van het protocol. De laatste kolom van Tabel B.4.4 suggereert dat toepassing van een glyfosaat bevattend GBM gelimiteerd wordt door het risico van AMPA. Voor persistente werkzame stoffen en/of hun metabolieten zijn de alternatieven 2 en 3 (scenario $C_{\min }=V R$ ) stringenter dan het eerste alternatief, het scenario $C_{\max }=$ MTR.

In plaats van tien keer MTR had ook één keer MTR als grens gekozen kunnen worden terwijl dezelfde beperkende voorwaarde (altijd is na één jaar de concentratie gedaald naar VR) van kracht blijft. Voor alternatief 3 geldt dus de grens $C_{\max }=$ MTR. Figuur B5.2 laat zien dat deze begrenzing van $C_{\max }(\leq$ MTR) intreedt bij alle actieve middelen met een DT50 van $55 \mathrm{~d}$ of minder.

Alternatief 2 heeft het bezwaar dat in de periode kort na de digestaatgift de concentratie een aantal malen het MTR kan bedragen. Wanneer de concentratie gemiddeld over het gehele jaar wordt berekend dan lijkt dit risico van de geselecteerde actieve stoffen betrekkelijk laag. In Figuur B5.3 wordt het jaargemiddelde van de concentratie t.o.v. de plateauwaarde $\mathrm{C}_{\text {max }}$ weergegeven als functie van DT50. Figuur B5.3 laat zien dat voor de geselecteerde stoffen geldt dat de jaargemiddelde bodemconcentraties zich bevinden tussen 2 en $17 \%$ van $C_{\max }$. Aangezien volgens het tweede alternatief het plateau $\mathrm{C}_{\max }$ het niveau van 10 keer MTR niet mag overschrijden, liggen jaargemiddelde concentraties in de landbouwbodem dus tussen 0,2 en 1,7 keer het niveau van MTR. Bij alternatief 2 is er geen sprake van "beperkte opvulling van de ruimte tussen VR en MTR" maar eerder van significante overschrijding van MTR. Dit bezwaar geldt niet voor alternatief 3 en daarom sluit deze variant het best aan bij het recente advies van de Technische Commissie Bodem (TCB 2010). Het jaargemiddelde van de concentraties van de geselecteerde actieve stoffen in de landbouwbodem liggen - met uitzondering van het persistente metaboliet AMPA van glyfosaat, tussen 2 en $17 \%$ van het MTR. 


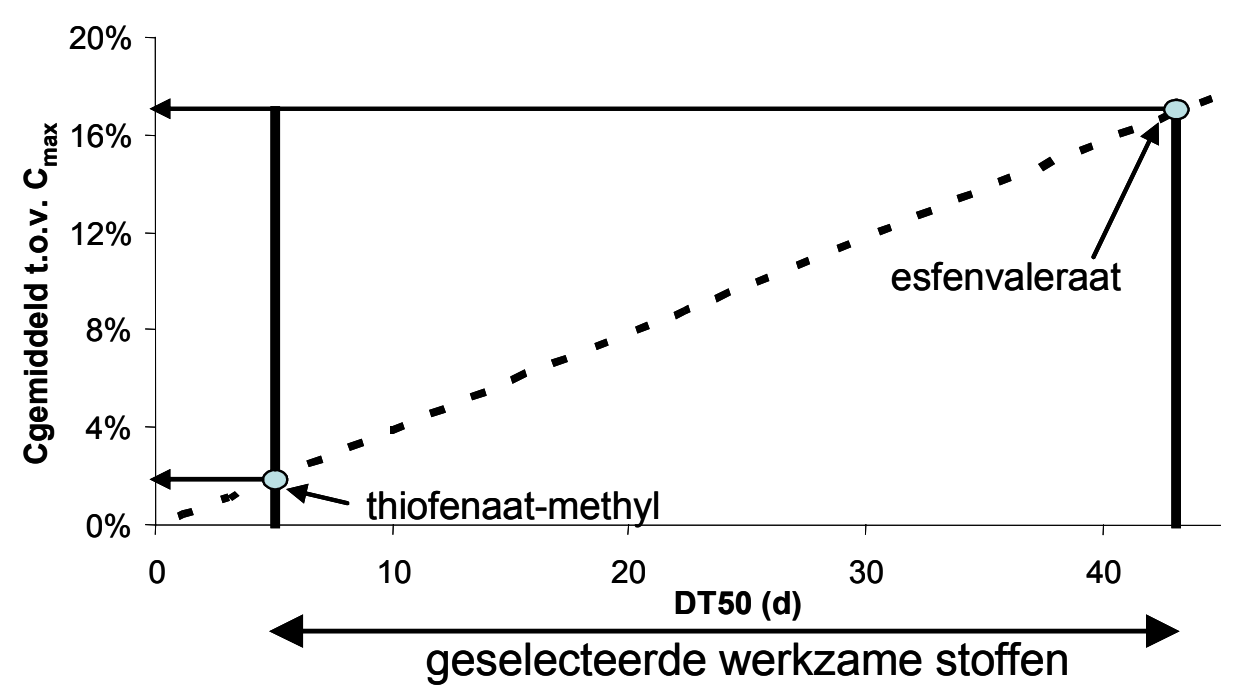

Figuur B5.3. De gestippelde curve geeft het jaargemiddelde van bodemconcentratie (geschaald naar $C_{\text {max }}$ ) van een werkzame stof als functie van DT50 voor alternatieven 2 en 3. Tussen de verticale balken bevinden zich alle geselecteerde stoffen.

In een worst-case scenario zou men op basis van jaargemiddelde bodemconcentraties op een eenvoudige manier het risico voor grondwater kunnen schatten. De concentratie in poriewater kan geschat worden m.b.v. de evenwichtspartitiemethode en de jaargemiddelde concentratie in de toplaag van de bodem. Dit is een conservatieve benadering. In de tijdspanne van een jaar en door de hoge afbraaksnelheden - niet alleen in de toplaag van $20 \mathrm{~cm}$ maar ook daaronder tijdens het transport naar het grondwater - kan de concentratie in het water aanzienlijk verder dalen. Een betere schatting wordt verkregen door de concentratie in het oppervlakkige grondwater door middel van een model te berekenen. Vanwege de beperkte tijd voor deze verkenning is dit niet gedaan.

\section{Conclusies berekening maximaal toelaatbare vracht volgens het protocol en de alternatieven}

Het Protocol: hoge plateauwaarde $C_{\max }$ is gelijk aan het $V R$

Volgens het huidige protocol (Van Dijk et al., 2009) zal als gevolg van digestaatgift de concentratie van het werkzame middel in de bovenste $20 \mathrm{~cm}$ van landbouwgrond het niveau van VR nooit overstijgen (Figuur B5.1, linker panel). Een jaar later, kort voor een nieuwe digestaatgift, zal de concentratie aanzienlijk lager zijn, afhankelijk van de afbraaksnelheid. Met de afbraakeigenschappen van de geselecteerde werkzame middelen zal die concentratie het niveau bereiken die orden van grootte lager ligt dan het VR. Voor het zeer labiele thiofanaat-methyl (DT50 = $5 \mathrm{~d}$ ) zal de concentratie bijna een factor van $10^{22}$ lager zijn dan het VR. Voor het meest persistente geselecteerde werkzame middel (met uitzondering van het metaboliet AMPA), esfenvaleraat met een DT50 van $44 \mathrm{~d}$, zal dat nog altijd een factor 310 lager zijn. Hieruit blijkt dat binnen de range van degradatiesnelheden van de geselecteerde actieve stoffen, het protocol leidt tot een negatief oordeel op basis van het jaargemiddelde van de concentraties die orden van grootte lager is dan het VR.

Alternatief 1: hoge plateauwaarde $C_{\max }$ is gelijk aan het MTR

Deze aanpassing op het protocol zal leiden tot een plateauwaarde van maximaal MTR (Figuur B5.1, linker panel maar $C_{\max }=$ MTR in plaats van VR). Door de zeer snelle afbraak van metam-natrium kan dit leiden tot een bodemconcentratie die vlak voor de volgende toediening maar liefst $5 \cdot 10^{13}$ keer lager is dan het VR. Maar voor het meer persistente pirimifos-methyl is dit maar een factor 1,5 lager dan het VR. Het nadeel van deze methodiek blijkt uit de toepassing op persistente werkzame stoffen. Wanneer deze op de bodem worden aangebracht tot het niveau van MTR kan de concentratie na een jaar hoger zijn dan VR. In principe kan het zelfs een veelvoud (maar nooit meer dan 100) van VR bedragen. Bij de persistente metaboliet AMPA van glyfosaat is dat een factor 19. Alternatief 1 kan voor zeer persistente actieve stoffen of metabolieten bezwaarlijk zijn. 
Alternatief 2: lage plateauwaarde $C_{\min }=V R$ met hoge plateauwaarde $C_{\max }=10 \cdot M T R$

Dit alternatief geeft bescherming bij belasting van de landbouwbodem door (persistente) werkzame middelen in co-vergistingsmaterialen. In dit alternatief wordt de voorwaarde gesteld dat na één jaar het niveau van VR wordt bereikt. Een mogelijk bezwaar kan zijn dat een korte periode na de digestaatgift de concentratie in de bodem zich op een niveau bevindt van een aantal malen het MTR, maar vanwege de begrenzing nooit meer dan 10 keer MTR.

Alternatief 3: lage plateauwaarde $C \min =V R$ met hoge plateauwaarde $C_{\max }=M T R$

Dit alternatief geeft een extra bescherming bij belasting door (persistente) werkzame middelen in covergistingsmaterialen. Evenals in Alternatief 2 wordt de voorwaarde gesteld dat de concentratie in de bodem na één jaar het niveau van VR heeft bereikt. Anders dan in Alternatief 2 zal na de digestaatgift de bodemconcentratie nooit het MTR overschrijden. Gezien het lage niveau van het jaargemiddelde van de concentraties van de 12 geselecteerde actieve stoffen (tussen 2 en $17 \%$ van het MTR, met uitzondering van het afbraakproduct AMPA van glyfosaat), sluit dit alternatief het beste aan bij "beperkte opvulling van de ruimte tussen VR en MTR" in het recente advies van de Technische Commissie Bodem (TCB, 2010).

\section{Beoordeling van de $\mathbf{2 7}$ geselecteerde co-vergistingsmaterialen}

Voor de beoordeling van de 27 geselecteerde co-vergistingsmaterialen voor wat betreft de 12 gewasbeschermingsmiddelen en biociden is een inschatting gemaakt van de werkelijke vracht aan residuen in het digestaat. Er zijn geen metingen van gehalten aan residuen in het digestaat beschikbaar. Daarom zijn deze afgeleid. Hiervoor was een aantal gegevens nodig:

1. Metingen van OOM-residugehalten in het gewas.

2. MRL-waarden (Maximum Residue Levels). Deze zijn nodig wanneer er geen metingen beschikbaar zijn.

3. conversiefactor voor de omrekening van het OOM-gehalte in het gewas naar het gehalte in het covergistingsmateriaal.

4. DT50 anaëroob voor het afleiden van de mate van afbraak in de vergistingstank.

5. NPK-gehalten van het covergistingsmateriaal om de maximaal toelaatbare vracht van het digestaat als meststof te berekenen

\section{OOM-gehalten en de conversiefactor}

In eerste instantie is de meetwaarde van een werkzame stof in de teelt gebruikt voor de beoordeling. Als deze niet beschikbaar was, is er gezocht naar een MRL (Maximum Residue Level). Er is voor het omrekenen van het OOM-gehalte in de teelt naar het gehalte in het covergistingsmateriaal een conversiefactor bepaald. Deze verschilt per covergistingsmateriaal. De factor is zowel voor een MRL als een meetwaarde gebruikt. Standaard is de waarde op 1 gezet. Voor sommige materialen is een factor groter dan 1 genomen:

\section{Aardappelpersvezels}

Aardappelpersvezels resteren na verwijdering van aardappelzetmeel. Het gehalte aan aardappelzetmeel in een aardappel is ongeveer $17 \%$ voor natgewicht en $77 \%$ voor drooggewicht (bron: AVEBE 2002, inleiding zetmeelchemie en zetmeel technologie). Als er van uitgegaan wordt dat $100 \%$ van het MRL in het covergistingsmateriaal terecht komt, zal dit leiden tot een factor 1,2 op het MRL $(100 / 83=1,2)$. De volgende stoffen zijn geanalyseerd maar zijn niet aangetoond boven de detectiegrens: deltamethrin, esfenvaleraat, lambda-cyhalotrin, MCPA en metribuzin. De detectiegrens ligt op 0,01 mg/Kg voor esfenvaleraat, lambda-cyhalotrin, MCPA en metribuzin en op 0,02 mg/Kg voor deltamethrin. Voor de overige stoffen is geen meetwaarde bekend. Deze fictieve grenswaarden zijn gebruikt voor de bepaling van de gehalten.

In de aardappelpersvezels is ook ethoprofos aangetoond, deze stof was bepalend bij de toelating als meststof na covergisting.

\section{Bloembollen}

Het restmateriaal van de teelt van tulpen en lelies bestaat uit (slechte) bollen, bolhuiden en pelresten. Er bestaan geen MRL's voor bloembollen. Op basis van de dosering kan de MRL voor uien omgerekend worden naar een concentratie in bloembollen. Verder wordt dezelfde conversiefactor toegepast als 
voor uienresten. Aangezien bloembollen niet vervoederd mogen worden en er dus geen MRL afgeleid is, ontbreekt er bij bloembollen een rem op het concentratieniveau. Door uit te gaan van een MRL voor uien, is het mogelijk dat dit een onderschatting oplevert van de contaminatie. Aanbevolen wordt de concentratie werkzame stoffen in de bloembollen te meten (Tabel B5.5).

Van de twaalf werkzame stoffen is voor 10 gerapporteerd dat deze bij de teelt van tulp, lelie en gladiool gebruikt kunnen zijn. In de beschikbare analyseresultaten is echter slechts op pirimifosmethyl geanalyseerd. De gerapporteerde aangetoonde concentratie is $0,01 \mathrm{mg} / \mathrm{kg}$ voor tulpenbollen en $0,06 \mathrm{mg} / \mathrm{kg}$ voor afgebroeide tulpenbollen.

\section{Tabel B5.5}

Omrekening van de MRL is op basis van de volgende doseringen.

\begin{tabular}{|c|c|c|c|}
\hline GBM & Dosering ui & Dosering bloembol & $\begin{array}{l}\text { Concentratie in hele } \\
\text { bloembol o.b.v. MRL ui }\end{array}$ \\
\hline & L/ha & L/ha & $\mathrm{mg} / \mathrm{kg}$ \\
\hline Deltamethrin & 0,3 & 0,4 & 0,13 \\
\hline Esfenvaleraat & 0,2 & 0,4 & 0,04 \\
\hline Fenmedifam & - & - & - \\
\hline Glyfosaat (AMPA) & - & - & - \\
\hline Lambda-cyhalothrin & 0,05 & 0,05 & 0,02 \\
\hline Mancozeb & 4,5 & 4 & 1 \\
\hline MCPA & - & - & - \\
\hline Metam-natrium & 300 & 750 & 0,05 \\
\hline Metribuzin & - & - & - \\
\hline Metsulfuron-methyl & - & - & - \\
\hline Pirimifos-methyl & - & - & - \\
\hline Thiofanaat-methyl & $0,4 \%$ & $1,2 \%$ & 0,3 \\
\hline
\end{tabular}

\section{Waterbroei tulpen}

Bij de waterbroei van tulpen worden vrijwel geen GBM's gebruikt. Het gehalte van GBM's in tulpen waterbroei zal dus gelijk zijn aan die in de bol zelf. Gezien de bemesting en het uitgroeien van de plant zal de verhouding tussen GBM en N/P afnemen waardoor de uiteindelijke vracht kleiner zal worden. De mate waarin is niet bekend. Gezien de beperkte hoeveelheid informatie kan de beoordeling van waterbroei-tulpen het beste uitgevoerd worden onder die van bloembollen.

\section{Gersteslijpmeelpellets}

De pellets zijn ongeveer $20 \%(18,3 \%)$ van de totale tarwestroom. Uitgaande dat $100 \%$ van het MRL in de pellets zit, zal dit leiden tot een factor 5 op het MRL. In tarwe is gemeten op esfenvaleraat en pirimifos-methyl, de laatste stof is boven de detectielimiet aangetoond met een maximale concentratie van $2,26 \mathrm{mg} / \mathrm{kg}$. Aangezien het om een analyse in tarwe gaat en niet in de pellets moet op deze concentratie dezelfde factor worden toegepast als op de MRL.

De overige stoffen zijn niet geanalyseerd.

\section{Uienpulp}

Uienpulp wordt geproduceerd tijdens de verwerking van uien voor de menselijke consumptie. Het product bestaat uit uien(schillen) en uienrokken. Met het uitgangspunt dat de uienpulp $10 \%$ van het totaalgewicht van de ui beslaat en dat $100 \%$ van het MRL in de uienrest zit, zal dit leiden tot een factor 10 op het MRL. Een andere vorm van uienpulp is uienperssap dat ontstaat bij de productie van uienolie. Voor dit proces worden de uien met $30 \%$ water gemengd voor verwerking. In dit geval kan daarom een factor van 0,7 op de MRL worden toegepast. 
In uienresten is thiofanaat-methyl aangetoond met een concentratie van $0,51 \mathrm{mg} / \mathrm{kg}$. Verder zijn de volgende stoffen ook aangetoond:
- Chloorprofam
$0,52 \mathrm{mg} / \mathrm{kg}$
- Thiofanaat-methyl
$0,51 \mathrm{mg} / \mathrm{kg}$
- Carbendazim
$0,15 \mathrm{mg} / \mathrm{kg}$
- Fluazinan
$0,03 \mathrm{mg} / \mathrm{kg}$
- Metalaxyl
$0,14 \mathrm{mg} / \mathrm{kg}$
- Tebuconazool
$1,3 \mathrm{mg} / \mathrm{kg}$
- Triadimenol
$0,91 \mathrm{mg} / \mathrm{kg}$
- Pendimethalin
$0,11 \mathrm{mg} / \mathrm{kg}$

In uienperssap is ook thiofanaat-methyl aangetoond met een concentratie van $6,9 \mathrm{mg} / \mathrm{L}$. Verder zijn de volgende stoffen aangetoond:

$\begin{array}{ll}\text { - Azoxystrobine } & 0,16 \mathrm{mg} / \mathrm{L} \\ \text { - Boscalid } & 0,4 \mathrm{mg} / \mathrm{L} \\ \text { - Carbendazim } & 10 \mathrm{mg} / \mathrm{L} \\ \text { - Dimethomorph } & 0,71 \mathrm{mg} / \mathrm{L} \\ \text { - Epoxiconazole } & 0,1 \mathrm{mg} / \mathrm{L} \\ \text { - Fluopicolide } & 0,12 \mathrm{mg} / \mathrm{L} \\ \text { - Imidacloprid } & 0,11 \mathrm{mg} / \mathrm{L} \\ \text { - Metalaxyl } & 0,27 \mathrm{mg} / \mathrm{L} \\ \text { - Prochloraz } & 0,1 \mathrm{mg} / \mathrm{L} \\ \text { - Tebuconazool } & 10 \mathrm{mg} / \mathrm{L}\end{array}$

Uitgaande dat het water in het perssap bestaat uit het aangemengde water $(30 \%)$ plus water in de uien (ong. 70\%) kunnen deze concentraties ook als $\mathrm{mg} / \mathrm{kg}$ ui worden gezien.

\section{Zonnebloemen}

In geëxtraheerd zonnebloemmeel is concentratie van GBM's wel mogelijk als deze niet geëxtraheerd worden. Het percentage olie dat geëxtraheerd wordt is maximaal $40 \%$

(http://www.piteba.com/nld/persgegevens.htm). Op de MRL kan daarom een factor van 1,7 toegepast worden. Er zijn geen analyseresultaten van GBM's in zonnebloempitten bekend. Ook is niet duidelijke welke van de 12 werkzame stoffen gebruikt worden voor de teelt van zonnebloemen (in het buitenland). Daarom is de beoordeling voor alle 12 werkzame stoffen uitgevoerd.

\section{Koolzaad}

Het gaat hier om het stro van koolzaad. Een conversiefactor is niet noodzakelijk omdat er vanuit gegaan wordt dat de MRL voor het stro gelijk is aan dat van het zaad zelf. Er zijn geen gemeten gehalten bekend voor koolzaadstro.

\section{Glycerine}

Het glycerine is afkomstig van dierlijk vet. Hier ligt het niet in de verwachting dat GBM's zullen worden aangetoond, voor de meeste stoffen is er echter wel een MRL voor in vlees, vet en organen beschikbaar. Daarnaast is het mogelijk om diergeneesmiddelen en veevoeradditieven aan te treffen. Van de twaalf GBM's is alleen deltamethrin als diergeneesmiddel geregistreerd voor runderen en schapen. Glycerine zou ook op andere diergeneesmiddelen beoordeeld moeten worden. De verhouding tussen glycerol en vetzuren in dierlijk vet is niet bekend. Daarom wordt er vanuit gegaan dat dit 1:1 is. Als het GBM voor $100 \%$ procent in het glycerol blijft moet er een factor 2 op de MRL worden toegepast.

Uit het toelatingsdossier van deltamethrin als diergeneesmiddel blijkt dat $72 \%$ op de plaats van toepassing (huid) blijft en dat excretie slechts $1,5 \%$ is. De stof heeft ook een hoge BCF in vis. Er kan vanuit gegaan worden dat 26,5\% van de dosis in het vet terecht komt. Met een dosering van 1 $\mathrm{mg} / \mathrm{kgbw}$ en $15 \%$ vet komt de concentratie op $1,8 \mathrm{mg} / \mathrm{kg}$ vet. Dit gehalte is echter hoger dan de $\mathrm{MRL}$ voor vet $(0,5 \mathrm{mg} / \mathrm{kg})$. 


\section{Afleiden anaërobe afbraak in vergistingstank}

Aangenomen is dat de vergistingstank een continue instroom heeft van mest en covergistingsmateriaal en een continue uitstroom van digestaat en biogas. Uit de massabalans volgt dan:

$\mathrm{Q}_{\text {in }} \cdot \mathrm{C}_{\text {in }}=\mathrm{Q}_{\text {out }} \cdot \mathrm{C}_{\text {out }}+\left(\ln 2 / \mathrm{T}_{1 / 2}\right) \cdot \mathrm{Vr} \cdot \mathrm{C}_{\text {out }}$

Waarbij $Q_{\text {in }}=$ debiet in $\mathrm{m}^{3} / \mathrm{d}$ van het covergistingsmateriaal, Qout $=$ debiet in $\mathrm{m}^{3} / \mathrm{d}$ van het digestaat, $\mathrm{C}_{\text {in }}=$ concentratie in het covergistingmateriaal, $\mathrm{C}_{\text {out }}=$ concentratie in het digestaat, $\mathrm{T}_{1 / 2}=$ halfwaardetijd van anaërobe afbraak in de vergistingsinstallatie en $\mathrm{Vr}=$ reactorvolume in $\mathrm{m}^{3}$.

Hieruit volgt dat:

$\mathrm{R}=1 /\left(1+\left(\ln 2 / \mathrm{T}_{1 / 2}\right) \mathrm{Tau}\right)$

Waarbij $\mathrm{R}=$ de fractie van het mengsel dat niet is afgebroken en Tau = verblijftijd van het mengsel in de vergistingsinstallatie.

De fractie die overblijft, is dan afhankelijk van de halfwaardetijd van een stof en de verblijftijd. In Fig. B5.4 staat die relatie afgebeeld, waarbij is aangenomen dat de verblijftijd in de tank 45 dagen is.

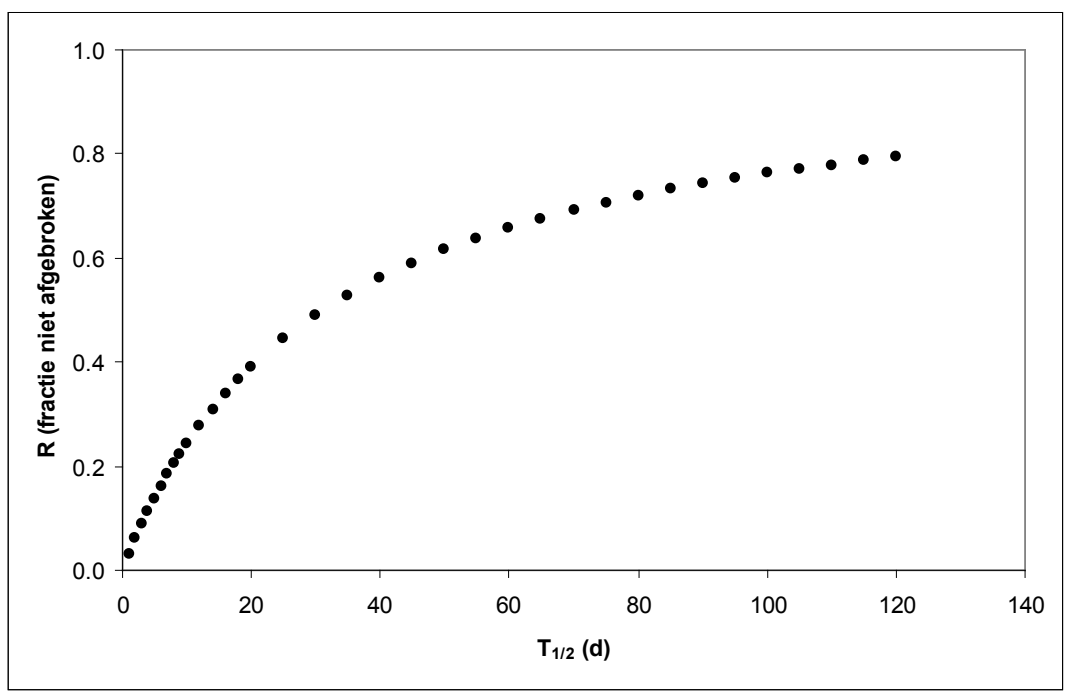

Figuur B5.4. De fractie werkzame stof die overblijft na 45 dagen in de vergistingsinstallatie, afhankelijk van de halfwaardetijd $\left(T_{1 / 2}\right)$ van die stof.

De biologische afbraak verloopt meestal sneller als de temperatuur hoger is. De meeste halfwaardetijden van stoffen worden gegeven voor 20 graden Celsius. Aangezien de temperatuur in de vergistingstank gemiddeld zo'n 40 graden Celsius is, moeten de berekende fracties hiervoor worden gecorrigeerd. Dit is gedaan door de $T_{1 / 2}$ van iedere stof door een waarde $2 * Q_{10}$ te delen, waarbij $Q_{10}$ ongeveer een waarde 2,6 heeft. Dit gaat uit van het principe dat bij een verhoging van 10 graden Celsius microbiologische processen ongeveer een factor 2,6 sneller verlopen. Bij 20 graden verhoging zullen deze processen dus ongeveer een factor 5 sneller verlopen.

In Tabel B5. 6 worden de halfwaardetijden gegeven voor de 12 stoffen ( $T_{1 / 2}$-lab anaëroob bij 20 graden Celsius), de herkomst van deze waarden en de fracties die overblijven na 45 dagen in de vergistingstank bij 20 en bij 40 graden Celsius. De halfwaardetijden van de 12 werkzame stoffen zijn in eerste instantie opgezocht in de EU-pesticides database

(http://ec.europa.eu/sanco_pesticides/public/index.cfm). Als ze hier niet beschikbaar waren, is verder gezocht in de RIVM-database (Ton van der Linden), of in de footprint-database

(http://sitem.herts.ac.uk/aeru/footprint/en/index.htm). Alleen voor pirimifos-methyl is een waarde genomen die minder betrouwbaar is, door het ontbreken van gegevens in genoemde databestanden. Echter, de waarde ligt redelijk in de buurt van wat verwacht zou mogen worden (pers. com. Emiel Rorije). Om die reden is de waarde toch meegenomen in de berekeningen. Voor MCPA geldt dat hier een fictieve waarde is genomen, aangezien alleen bekend is dat de stof vrijwel niet afbreekt. 
$\mathrm{Er}$ is in eerste instantie een $\mathrm{T}_{1 / 2}$ voor de bodem genomen. Bij het ontbreken daarvan is gekozen voor een waarde in het sediment. Mocht die er ook niet zijn, dan is gekozen voor een 'whole system' waarde (sediment en water).

\section{Tabel B5.6}

De 12 geselecteerde stoffen met informatie over de anaërobe afbraak.

\begin{tabular}{|c|c|c|c|c|}
\hline \multirow[t]{4}{*}{ Werkzame stof } & $\mathrm{T}_{1 / 2}$-lab & Herkomst halfwaardetijd & Fractie & \\
\hline & $\left(20^{\circ} \mathrm{C}\right)$ & & na 45 & na 45 \\
\hline & Anaëroob & & dagen & dagen \\
\hline & & & $20^{\circ} \mathrm{C}$ & $40^{\circ} \mathrm{C}$ \\
\hline Metsulfuron-methyl & 175 & DT50 Sediment EU pesticides database & 0,85 & 0,538 \\
\hline Metribuzin & 109 & DT50 Bodem database RIVM & 0,78 & 0,41 \\
\hline \multirow[t]{3}{*}{ Pirimifos-methyl } & 25 & http://www.list-company.com/leads- & 0,44 & 0,14 \\
\hline & & info/1508281/Pirimiphos-Methyl-Chemicals- & & \\
\hline & & Shanghai-China.shtml & & \\
\hline Deltamethrin & 32 & DT50 EU pesticides database & 0,51 & 0,17 \\
\hline Mancozeb & 11 & DT50 EU pesticides database & 0,26 & 0,07 \\
\hline Lambda-cyhalothrin & 101 & DT50 EU pesticides database & 0,76 & 0,39 \\
\hline Fenmedifam & 15 & DT50 EU pesticides database & 0,32 & 0,09 \\
\hline MCPA & 10000 & non-degradable & 0,99 & 0,98 \\
\hline Metam-natrium & 0,07 & Footprint database & 0,002 & 0,0004 \\
\hline Glyfosaat & 27 & DT50 Whole system; EU pesticides database & 0,46 & 0,15 \\
\hline Thiofanaat-methyl & 0,02 & DT50 EU pesticides database & 0,0006 & 0,0001 \\
\hline Esfenvaleraat & 54 & DT50 Whole system; EU pesticides database & 0,63 & 0,26 \\
\hline
\end{tabular}

\section{Berekening van werkelijke vracht werkzame stoffen en overschrijdingsfactoren}

De gehalten totaal stikstof en fosfaat van de covergistingsmaterialen, en de variatie van die gehalten (minimum en maximum), zijn uit de aangeleverde dossiers gehaald, of komen uit gegevens van het bronnenonderzoek. De gehalten zijn in $\mathrm{g} / \mathrm{Kg}$ versgewicht. Deze gehalten zijn gebruikt om de maximaal toelaatbare hoeveelheid co-vergistingsmateriaal te berekenen (in ton/ha/jr) die als meststof mag worden opgebracht. De maximaal toelaatbare hoeveelheid totaal stikstof is gesteld op $250 \mathrm{Kg} \mathrm{N} / \mathrm{ha}$,

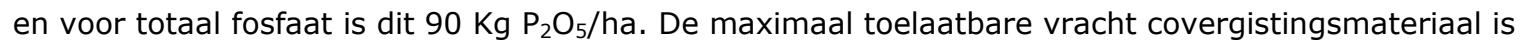
voor zowel $\mathrm{N}$ als $\mathrm{P}$ berekend door:

Voor N (in ton/ha): 250/concentratie $\mathrm{N}$ in covergistingsmateriaal

Voor $\mathrm{P}$ (in ton/ha): 90/concentratie $\mathrm{P}_{2} \mathrm{O}_{5}$ in covergistingsmateriaal

De vracht met de laagste waarde wordt gebruikt om de vracht werkzame stof uit te rekenen volgens het protocol versie 2.1.:

$\mathrm{V}=\mathrm{M} * \mathrm{C} * \mathrm{f}$

Voor de drie alternatieve systematieken is deze formule gebruikt:

$V=M *(C / 2) * f * F$

Waarbij:

$\mathrm{V}=$ Vracht werkzame stof (in $\mathrm{g} / \mathrm{ha}$ )

$\mathrm{M}=$ maximaal toelaatbare vracht co-vergistingsmateriaal, o.b.v. $\mathrm{N}$ en $\mathrm{P}$ (ton/ha)

$\mathrm{C}=$ Concentratie werkzame stof in het gewas ( $\mathrm{mg} / \mathrm{Kg}$ vers gewicht)

$\mathrm{f}=$ conversiefactor voor gehalten in gewas naar covergistingsmateriaal

$F=$ fractie van de werkzame stof die na anaërobe afbraak in de vergistingstank overblijft

De concentratie werkzame stof in het gewas wordt door 2 gedeeld omdat het co-vergistingsmateriaal 1:1 gemengd wordt met mest waardoor er een verdunning optreedt van de werkzame stof. Dit is echter alleen gedaan bij de drie alternatieve berekeningen. Het wijkt af van het protocol, maar levert 
een beter beeld van de risico's. Dit geldt ook voor het meenemen van anaërobe afbraak in de berekeningen.

De overschrijdingsfactoren zijn tot slot berekend door de geschatte (werkelijke) vracht werkzame stof te delen door de maximaal toelaatbare vracht werkzame stof uit Tabel B5.4. Een factor hoger dan 1 wil dan zeggen dat de vracht hoger is dan de maximaal toelaatbare vracht, waardoor er een overschrijding plaatsvindt. In Tabel B5.7 zijn de vrachten en de overschrijdingsfactoren, volgens het protocol en de alternatieven, voor de verschillende werkzame stoffen en co-vergistingsmaterialen gegeven.

\section{Conclusies beoordeling co-vergistingsmaterialen}

- Deze beoordeling heeft alleen betrekking op de 12 geselecteerde werkzame stoffen. Het valt niet uit te sluiten dat er bij meer werkzame stoffen een overschrijding plaatsvindt.

- Het huidige protocol geeft aanzienlijk meer overschrijdingen dan bij de alternatieve berekeningen.

- Doordat detectielimieten en MRL's relatief hoog zijn vergeleken met de (vermoedelijke) werkelijke gehalten valt het te verwachten dat er minder overschrijdingen plaatsvinden als er werkelijk gemeten waarden zouden worden gebruikt.

- Ten opzichte van de jaardosering als gewasbeschermingsmiddel zijn er geen overschrijdingen gevonden.

- Afbraak in de vergistingstank kan voor lagere gehalten in het digestaat zorgen. Dit kan oplopen tot 4 orden van grootte bij de 12 geselecteerde werkzame stoffen.

- Met name pirimifos-methyl en metsulfuron-methyl zorgen nog voor overschrijdingen bij de alternatieve vrachtberekeningen.

- De metabolieten van de stoffen, zoals AMPA en Carbendazim, zouden nog apart beoordeeld moeten worden.

\section{Aanbevelingen}

- Herzie de methodiek voor het bepalen van de maximale vracht in het Protocol 2.1 (Van Dijk et al., 2009).

- $\quad$ Ontwerp een matrix met de output van modelberekeningen voor het schatten van grondwaterconcentraties van actieve stoffen of persistente metabolieten voor verscheidene bodem-water partitiecoefficienten en DT50 waarden.

- Valideer de berekende vrachten van de onderzochte werkzame stoffen in het digestaat met metingen.

- De metabolieten van de 12 werkzame stoffen zouden nog nader bekeken moeten worden. Er moeten duidelijke afspraken komen over het beoordelen van metabolieten in het digestaat. 
Tabel B5.7.

Gemiddelde, minimum en maximum vrachten van werkzame stoffen in co-vergistingsmaterialen, en overschrijdingsfactoren t.o.v. de maximaal toelaatbare vracht. Gemiddelde vrachten zijn berekend, zowel met als zonder anaërobe afbraak in de vergistingsinstallatie. Minimum en maximum vrachten zijn gebaseerd op variatie in totaal stikstof en fosfor gehalten, en niet op variatie in gehalten werkzame stoffen. Herkomst van het gehalte kan een 'Maximum Residue Level' (MRL) zijn, of een meting. Indien de meting is gebaseerd op een detectielimiet, dan is dit aangegeven met (dl).

\begin{tabular}{|c|c|c|c|c|c|c|c|c|c|c|}
\hline Werkzame stof & $\begin{array}{l}\text { Co-vergistings- } \\
\text { materiaal }\end{array}$ & $\begin{array}{l}\text { Herkomst } \\
\text { gehalte }\end{array}$ & $\begin{array}{l}\text { Gemiddelde } \\
\text { geschatte } \\
\text { vracht } \\
\text { actieve stof } \\
\text { zonder } \\
\text { anaërobe } \\
\text { afbraak } \\
\text { (g/Ha) }\end{array}$ & $\begin{array}{l}\text { Gemiddelde } \\
\text { geschatte } \\
\text { vracht } \\
\text { actieve stof } \\
\text { met } \\
\text { anaërobe } \\
\text { afbraak } \\
(\mathrm{g} / \mathrm{Ha})\end{array}$ & $\begin{array}{l}\text { Minimum } \\
\text { geschatte } \\
\text { vracht } \\
\text { actieve } \\
\text { stof met } \\
\text { anaërobe } \\
\text { afbraak } \\
\text { (g/Ha) }\end{array}$ & $\begin{array}{l}\text { Maximum } \\
\text { geschatte } \\
\text { vracht } \\
\text { actieve } \\
\text { stof met } \\
\text { anaërobe } \\
\text { afbraak } \\
\text { (g/Ha) }\end{array}$ & $\begin{array}{l}\text { Factor } \\
\text { protocol } \\
\text { zonder } \\
\text { anaërobe } \\
\text { afbraak }\end{array}$ & $\begin{array}{l}\text { Factor } \\
\text { Alternatief } \\
1 \\
\text { met } \\
\text { anaërobe } \\
\text { afbraak }\end{array}$ & $\begin{array}{l}\text { Factor } \\
\text { Alternatief } \\
2 \\
\text { met } \\
\text { anaërobe } \\
\text { afbraak }\end{array}$ & $\begin{array}{l}\text { Factor } \\
\text { Alternatief } \\
3 \\
\text { met } \\
\text { anaërobe } \\
\text { afbraak }\end{array}$ \\
\hline deltamethrin & Stro van koolzaad & MRL & 1,16 & 0,20 & & & 174,3 & 0,1 & $<0,1$ & 0,1 \\
\hline glyfosaat & Stro van koolzaad & MRL & 115,58 & 17,06 & & & 0,2 & $<0,1$ & $<0,1$ & $<0,1$ \\
\hline metsulfuron-methyl & Tarwe (hele plant) & MRL & 1,41 & 0,74 & & & 10149,3 & 26,8 & 2,7 & 26,8 \\
\hline pirimifos-methyl & Tarwe (hele plant) & Meting & 8,50 & 1,17 & & & 51173,8 & 35,3 & 3,5 & 35,3 \\
\hline deltamethrin & Tarwe (hele plant) & MRL & 56,25 & 9,58 & & & 8480,8 & 7,2 & 0,7 & 7,2 \\
\hline mancozeb & Tarwe (hele plant) & MRL & 28,13 & 1,85 & & & 275,6 & 0,1 & $<0,1$ & 0,1 \\
\hline lambda-cyhalothrin & Tarwe (hele plant) & Meting (dl) & 0,28 & 0,11 & & & 290,1 & 0,6 & 0,1 & 0,6 \\
\hline MCPA & Tarwe (hele plant) & MRL & 1,41 & 1,38 & & & 51,0 & 0,3 & $<0,1$ & 0,3 \\
\hline glyfosaat & Tarwe (hele plant) & Meting & 2,69 & 0,40 & & & $<0,1$ & $<0,1$ & $<0,1$ & $<0,1$ \\
\hline thiofanaat-methyl & Tarwe (hele plant) & MRL & 1,41 & $<0,01$ & & & 39,4 & $<0,1$ & $<0,1$ & $<0,1$ \\
\hline esfenvaleraat & Tarwe (hele plant) & MRL & 0,56 & 0,14 & & & 29,9 & $<0,1$ & $<0,1$ & $<0,1$ \\
\hline deltamethrin & Erwten (hele plant) & MRL & 8,19 & 1,39 & & & 1234,3 & 1,1 & 0,1 & 1,1 \\
\hline lambda-cyhalothrin & Erwten (hele plant) & MRL & 0,82 & 0,32 & & & 844,5 & 1,7 & 0,2 & 1,7 \\
\hline glyfosaat & Erwten (hele plant) & MRL & 1,64 & 0,24 & & & $<0,1$ & $<0,1$ & $<0,1$ & $<0,1$ \\
\hline esfenvaleraat & Erwten (hele plant) & MRL & 0,33 & 0,08 & & & 17,4 & $<0,1$ & $<0,1$ & $<0,1$ \\
\hline metsulfuron-methyl & Koekmix & MRL & 0,47 & 0,25 & 0,15 & 0,54 & 3383,1 & 8,9 & 0,9 & 8,9 \\
\hline pirimifos-methyl & Koekmix & Meting & 2,83 & 0,39 & 0,23 & 0,85 & 17057,9 & 11,8 & 1,2 & 11,8 \\
\hline deltamethrin & Koekmix & MRL & 18,75 & 3,19 & 1,90 & 6,96 & 2826,9 & 2,4 & 0,2 & 2,4 \\
\hline mancozeb & Koekmix & MRL & 9,38 & 0,62 & 0,37 & 1,35 & 91,9 & $<0,1$ & $<0,1$ & $<0,1$ \\
\hline lambda-cyhalothrin & Koekmix & Meting (dl) & 0,09 & 0,04 & 0,02 & 0,08 & 96,7 & 0,2 & $<0,1$ & 0,2 \\
\hline MCPA & Koekmix & MRL & 0,47 & 0,46 & 0,27 & 1,01 & 17,0 & 0,1 & $<0,1$ & 0,1 \\
\hline glyfosaat & Koekmix & Meting & 0,90 & 0,13 & 0,08 & 0,29 & $<0,1$ & $<0,1$ & $<0,1$ & $<0,1$ \\
\hline thiofanaat-methyl & Koekmix & MRL & 0,47 & $<0,01$ & $<0,01$ & $<0,01$ & 13,1 & $<0,1$ & $<0,1$ & $<0,1$ \\
\hline esfenvaleraat & Koekmix & MRL & 0,19 & 0,05 & 0,03 & 0,11 & 10,0 & $<0,1$ & $<0,1$ & $<0,1$ \\
\hline deltamethrin & Uienpulp & Meting (dl) & 0,48 & 0,08 & & & 72,2 & 0,1 & $<0,1$ & 0,1 \\
\hline
\end{tabular}




\begin{tabular}{|c|c|c|c|c|c|c|c|c|c|c|}
\hline Werkzame stof & $\begin{array}{l}\text { Co-vergistings- } \\
\text { materiaal }\end{array}$ & $\begin{array}{l}\text { Herkomst } \\
\text { gehalte }\end{array}$ & $\begin{array}{l}\text { Gemiddelde } \\
\text { geschatte } \\
\text { vracht } \\
\text { actieve stof } \\
\text { zonder } \\
\text { anaërobe } \\
\text { afbraak } \\
(\mathrm{g} / \mathrm{Ha})\end{array}$ & $\begin{array}{l}\text { Gemiddelde } \\
\text { geschatte } \\
\text { vracht } \\
\text { actieve stof } \\
\text { met } \\
\text { anaërobe } \\
\text { afbraak } \\
(\mathrm{g} / \mathrm{Ha})\end{array}$ & $\begin{array}{l}\text { Minimum } \\
\text { geschatte } \\
\text { vracht } \\
\text { actieve } \\
\text { stof met } \\
\text { anaërobe } \\
\text { afbraak } \\
\text { (g/Ha) }\end{array}$ & $\begin{array}{l}\text { Maximum } \\
\text { geschatte } \\
\text { vracht } \\
\text { actieve } \\
\text { stof met } \\
\text { anaërobe } \\
\text { afbraak } \\
(\mathrm{g} / \mathrm{Ha})\end{array}$ & $\begin{array}{l}\text { Factor } \\
\text { protocol } \\
\text { zonder } \\
\text { anaërobe } \\
\text { afbraak }\end{array}$ & $\begin{array}{l}\text { Factor } \\
\text { Alternatief } \\
1 \\
\text { met } \\
\text { anaërobe } \\
\text { afbraak }\end{array}$ & $\begin{array}{l}\text { Factor } \\
\text { Alternatief } \\
2 \\
\text { met } \\
\text { anaërobe } \\
\text { afbraak }\end{array}$ & $\begin{array}{l}\text { Factor } \\
\text { Alternatief } \\
\mathbf{3} \\
\text { met } \\
\text { anaërobe } \\
\text { afbraak }\end{array}$ \\
\hline mancozeb & Uienpulp & MRL & 478,93 & 31,55 & & & 4693,5 & 1,5 & 0,2 & 1,5 \\
\hline lambda-cyhalothrin & Uienpulp & Meting (dl) & 0,48 & 0,19 & & & 494,1 & 1,0 & 0,1 & 1,0 \\
\hline metam-natrium & Uienpulp & MRL & 0,96 & $<0,01$ & & & 341,3 & $<0,1$ & $<0,1$ & $<0,1$ \\
\hline glyfosaat & Uienpulp & MRL & 4,79 & 0,71 & & & $<0,1$ & $<0,1$ & $<0,1$ & $<0,1$ \\
\hline thiofanaat-methyl & Uienpulp & Meting & 244,25 & 0,03 & & & 6839,1 & $<0,1$ & $<0,1$ & $<0,1$ \\
\hline esfenvaleraat & Uienpulp & Meting (dl) & 0,48 & 0,12 & & & 25,4 & $<0,1$ & $<0,1$ & $<0,1$ \\
\hline metribuzin & Aardappelpersvezels & Meting (dl) & 0,55 & 0,22 & & & 339,2 & 0,7 & 0,1 & 0,7 \\
\hline deltamethrin & Aardappelpersvezels & Meting (dl) & 1,09 & 0,19 & & & 164,5 & 0,1 & 0,0 & 0,1 \\
\hline mancozeb & Aardappelpersvezels & MRL & 16,37 & 1,08 & & & 160,4 & 0,1 & 0,0 & 0,1 \\
\hline lambda-cyhalothrin & Aardappelpersvezels & Meting (dl) & 0,55 & 0,21 & & & 562,9 & 1,1 & 0,1 & 1,1 \\
\hline MCPA & Aardappelpersvezels & Meting (dl) & 0,55 & 0,54 & & & 19,8 & 0,1 & 0,0 & 0,1 \\
\hline metam-natrium & Aardappelpersvezels & MRL & 1,09 & $<0,01$ & & & 388,9 & $<0,1$ & $<0,1$ & $<0,1$ \\
\hline glyfosaat & Aardappelpersvezels & MRL & 27,28 & 4,03 & & & 0,1 & $<0,1$ & $<0,1$ & $<0,1$ \\
\hline esfenvaleraat & Aardappelpersvezels & Meting (dl) & 0,55 & 0,14 & & & 29,0 & $<0,1$ & $<0,1$ & $<0,1$ \\
\hline metsulfuron-methyl & Bierbostel & MRL & 0,54 & 0,29 & 0,25 & 0,35 & 3908,9 & 10,3 & 1,0 & 10,3 \\
\hline pirimifos-methyl & Bierbostel & Meting & 3,27 & 0,45 & 0,40 & 0,55 & 19708,8 & 13,6 & 1,4 & 13,6 \\
\hline deltamethrin & Bierbostel & MRL & 21,66 & 3,69 & 3,27 & 4,49 & 3266,3 & 2,8 & 0,3 & 2,8 \\
\hline mancozeb & Bierbostel & MRL & 10,83 & 0,71 & 0,63 & 0,87 & 106,2 & $<0,1$ & $<0,1$ & $<0,1$ \\
\hline lambda-cyhalothrin & Bierbostel & Meting (dl) & 0,11 & 0,04 & 0,04 & 0,05 & 111,7 & 0,2 & $<0,1$ & 0,2 \\
\hline MCPA & Bierbostel & MRL & 0,54 & 0,53 & 0,47 & 0,65 & 19,7 & 0,1 & $<0,1$ & 0,1 \\
\hline glyfosaat & Bierbostel & MRL & 108,32 & 15,99 & 14,19 & 19,44 & 0,2 & $<0,1$ & $<0,1$ & $<0,1$ \\
\hline thiofanaat-methyl & Bierbostel & MRL & 3,25 & $<0,01$ & $<0,01$ & $<0,01$ & 91,0 & $<0,1$ & $<0,1$ & $<0,1$ \\
\hline esfenvaleraat & Bierbostel & MRL & 2,17 & 0,56 & 0,49 & 0,68 & 115,0 & 0,1 & $<0,1$ & 0,1 \\
\hline glyfosaat & Maïsgluten & MRL & 1,28 & 0,19 & & & $<0,1$ & $<0,1$ & $<0,1$ & $<0,1$ \\
\hline deltamethrin & Melasse & MRL & 9,77 & 1,66 & 0,55 & 1,66 & 1472,4 & 1,3 & 0,1 & 1,3 \\
\hline lambda-cyhalothrin & Melasse & MRL & 0,39 & 0,15 & 0,05 & 0,15 & 403,0 & 0,8 & 0,1 & 0,8 \\
\hline fenmedifam & Melasse & MRL & 1,95 & 0,17 & 0,06 & 0,17 & 279,4 & 0,1 & $<0,1$ & 0,1 \\
\hline metam-natrium & Melasse & MRL & 0,39 & $<0,01$ & $<0,01$ & $<0,01$ & 139,2 & $<0,1$ & $<0,1$ & $<0,1$ \\
\hline glyfosaat & Melasse & MRL & 1,95 & 0,29 & 0,10 & 0,29 & $<0,1$ & $<0,1$ & $<0,1$ & $<0,1$ \\
\hline esfenvaleraat & Melasse & MRL & 19,53 & 5,02 & 1,66 & 5,02 & 1036,8 & 1,3 & 0,3 & 1,3 \\
\hline
\end{tabular}

142 | wOt-technical report 70 


\begin{tabular}{|c|c|c|c|c|c|c|c|c|c|c|}
\hline Werkzame stof & $\begin{array}{l}\text { Co-vergistings- } \\
\text { materiaal }\end{array}$ & $\begin{array}{l}\text { Herkomst } \\
\text { gehalte }\end{array}$ & $\begin{array}{l}\text { Gemiddelde } \\
\text { geschatte } \\
\text { vracht } \\
\text { actieve stof } \\
\text { zonder } \\
\text { anaërobe } \\
\text { afbraak } \\
\text { (g/Ha) }\end{array}$ & $\begin{array}{l}\text { Gemiddelde } \\
\text { geschatte } \\
\text { vracht } \\
\text { actieve stof } \\
\text { met } \\
\text { anaërobe } \\
\text { afbraak } \\
\text { ( } / \mathrm{Ha})\end{array}$ & $\begin{array}{l}\text { Minimum } \\
\text { geschatte } \\
\text { vracht } \\
\text { actieve } \\
\text { stof met } \\
\text { anaërobe } \\
\text { afbraak } \\
\text { (g/Ha) }\end{array}$ & $\begin{array}{l}\text { Maximum } \\
\text { geschatte } \\
\text { vracht } \\
\text { actieve } \\
\text { stof met } \\
\text { anaërobe } \\
\text { afbraak } \\
(\mathrm{g} / \mathrm{Ha})\end{array}$ & $\begin{array}{l}\text { Factor } \\
\text { protocol } \\
\text { zonder } \\
\text { anaërobe } \\
\text { afbraak }\end{array}$ & $\begin{array}{l}\text { Factor } \\
\text { Alternatief } \\
1 \\
\text { met } \\
\text { anaërobe } \\
\text { afbraak }\end{array}$ & $\begin{array}{l}\text { Factor } \\
\text { Alternatief } \\
2 \\
\text { met } \\
\text { anaërobe } \\
\text { afbraak }\end{array}$ & $\begin{array}{l}\text { Factor } \\
\text { Alternatief } \\
\mathbf{3} \\
\text { met } \\
\text { anaërobe } \\
\text { afbraak }\end{array}$ \\
\hline deltamethrin & Raapschroot & Meting (dl) & $<0,01$ & $<0,01$ & $<0,01$ & $<0,01$ & 0,3 & $<0,1$ & $<0,1$ & $<0,1$ \\
\hline glyfosaat & Raapschroot & MRL & 18,37 & 2,71 & 2,66 & 2,71 & $<0,1$ & $<0,1$ & $<0,1$ & $<0,1$ \\
\hline deltamethrin & Weipoeder & & Onbekend & Onbekend & Onbekend & Onbekend & Onbek. & Onbek. & Onbek. & Onbek. \\
\hline MCPA & Weipoeder & MRL & 0,16 & 0,16 & 0,16 & 4,43 & 5,8 & $<0,0$ & $<0,1$ & $<0,1$ \\
\hline metam-natrium & Weipoeder & & Onbekend & Onbekend & Onbekend & Onbekend & Onbek. & Onbek. & Onbek. & Onbek. \\
\hline glyfosaat & Weipoeder & & Onbekend & Onbekend & Onbekend & Onbekend & Onbek. & Onbek. & Onbek. & Onbek. \\
\hline esfenvaleraat & Weipoeder & & Onbekend & Onbekend & Onbekend & Onbekend & Onbek. & Onbek. & Onbek. & Onbek. \\
\hline metsulfuron-methyl & Gersteslijpmeelpellets & MRL & 0,48 & 0,25 & & & 3479,8 & 9,2 & 0,9 & 9,2 \\
\hline pirimifos-methyl & Gersteslijpmeelpellets & Meting & 2,91 & 0,40 & & & 17545,3 & 12,1 & 1,2 & 12,1 \\
\hline deltamethrin & Gersteslijpmeelpellets & Meting (dl) & 0,19 & 0,03 & & & 29,1 & $<0,1$ & $<0,1$ & $<0,1$ \\
\hline mancozeb & Gersteslijpmeelpellets & MRL & 9,64 & 0,64 & & & 94,5 & $<0,1$ & $<0,1$ & $<0,1$ \\
\hline lambda-cyhalothrin & Gersteslijpmeelpellets & Meting (dl) & 0,10 & 0,04 & & & 99,5 & 0,2 & $<0,1$ & 0,2 \\
\hline MCPA & Gersteslijpmeelpellets & MRL & 0,48 & 0,47 & & & 17,5 & $<0,1$ & $<0,1$ & $<0,1$ \\
\hline glyfosaat & Gersteslijpmeelpellets & Meting & 0,92 & 0,14 & & & $<0,1$ & $<0,1$ & $<0,1$ & $<0,1$ \\
\hline thiofanaat-methyl & Gersteslijpmeelpellets & MRL & 0,48 & $<0,01$ & & & 13,5 & $<0,1$ & $<0,1$ & $<0,1$ \\
\hline esfenvaleraat & Gersteslijpmeelpellets & Meting (dl) & 0,10 & 0,02 & & & 5,1 & $<0,1$ & $<0,1$ & $<0,1$ \\
\hline deltamethrin & Koffiedik & Meting (dl) & 0,14 & 0,12 & & & 20,7 & $<0,1$ & $<0,1$ & $<0,1$ \\
\hline Mancozeb & Koffiedik & Meting (dl) & 0,14 & 0,05 & & & 7,3 & $<0,1$ & $<0,1$ & $<0,1$ \\
\hline lambda-cyhalothrin & Koffiedik & Meting (dl) & 0,14 & 0,05 & & & 141,7 & 0,3 & $<0,1$ & 0,3 \\
\hline pirimifos-methyl & Koffiedik & Meting (dl) & 0,14 & 0,02 & & & 827,2 & 0,6 & $<0,1$ & 0,6 \\
\hline deltamethrin & Bietenperspulp & MRL & 15,24 & 2,60 & & & 2298,3 & 2,0 & 0,2 & 2,0 \\
\hline lambda-cyhalothrin & Bietenperspulp & MRL & 0,61 & 0,24 & & & 629,0 & 1,2 & 0,1 & 1,2 \\
\hline fenmedifam & Bietenperspulp & MRL & 3,05 & 0,27 & & & 436,2 & 0,2 & $<0,1$ & 0,2 \\
\hline metam-natrium & Bietenperspulp & MRL & 0,61 & $<0,01$ & & & 217,3 & $<0,1$ & $<0,1$ & $<0,1$ \\
\hline glyfosaat & Bietenperspulp & MRL & 3,05 & 0,45 & & & $<0,1$ & $<0,1$ & $<0,1$ & $<0,1$ \\
\hline esfenvaleraat & Bietenperspulp & MRL & 30,49 & 7,84 & & & 1618,4 & 2,1 & 0,4 & 2,1 \\
\hline metribuzin & Aardappelstoomsch. & Meting (dl) & 0,36 & 0,15 & 0,11 & 0,2012 & 223,8 & 0,5 & $<0,1$ & 0,5 \\
\hline deltamethrin & Aardappelstoomsch. & Meting & 0,47 & 0,08 & 0,06 & 0,1083 & 70,6 & $<0,1$ & $<0,1$ & $<0,1$ \\
\hline mancozeb & Aardappelstoomsch. & Meting & 6,55 & 0,43 & 0,33 & 0,5865 & 64,2 & $<0,1$ & $<0,1$ & $<0,1$ \\
\hline lambda-cyhalothrin & Aardappelstoomsch. & Meting (dl) & 0,36 & 0,14 & 0,11 & 0,1923 & 371,4 & 0,7 & $<0,1$ & 0,7 \\
\hline
\end{tabular}




\begin{tabular}{|c|c|c|c|c|c|c|c|c|c|c|}
\hline Werkzame stof & $\begin{array}{l}\text { Co-vergistings- } \\
\text { materiaal }\end{array}$ & $\begin{array}{l}\text { Herkomst } \\
\text { gehalte }\end{array}$ & $\begin{array}{l}\text { Gemiddelde } \\
\text { geschatte } \\
\text { vracht } \\
\text { actieve stof } \\
\text { zonder } \\
\text { anaërobe } \\
\text { afbraak } \\
\text { (g/Ha) }\end{array}$ & $\begin{array}{l}\text { Gemiddelde } \\
\text { geschatte } \\
\text { vracht } \\
\text { actieve stof } \\
\text { met } \\
\text { anaërobe } \\
\text { afbraak } \\
\text { (g/Ha) }\end{array}$ & $\begin{array}{l}\text { Minimum } \\
\text { geschatte } \\
\text { vracht } \\
\text { actieve } \\
\text { stof met } \\
\text { anaërobe } \\
\text { afbraak } \\
\text { (g/Ha) }\end{array}$ & $\begin{array}{l}\text { Maximum } \\
\text { geschatte } \\
\text { vracht } \\
\text { actieve } \\
\text { stof met } \\
\text { anaërobe } \\
\text { afbraak } \\
(\mathrm{g} / \mathrm{Ha})\end{array}$ & $\begin{array}{l}\text { Factor } \\
\text { protocol } \\
\text { zonder } \\
\text { anaërobe } \\
\text { afbraak }\end{array}$ & $\begin{array}{l}\text { Factor } \\
\text { Alternatief } \\
1 \\
\text { met } \\
\text { anaërobe } \\
\text { afbraak }\end{array}$ & $\begin{array}{l}\text { Factor } \\
\text { Alternatief } \\
2 \\
\text { met } \\
\text { anaërobe } \\
\text { afbraak }\end{array}$ & $\begin{array}{l}\text { Factor } \\
\text { Alternatief } \\
\mathbf{3} \\
\text { met } \\
\text { anaërobe } \\
\text { afbraak }\end{array}$ \\
\hline MCPA & Aardappelstoomsch. & Meting (dl) & 0,36 & 0,35 & 0,27 & 0,4816 & 13,1 & $<0,1$ & $<0,1$ & $<0,1$ \\
\hline metam-natrium & Aardappelstoomsch. & MRL & 0,72 & $<0,01$ & $<0,01$ & $<0,01$ & 256,6 & $<0,1$ & $<0,1$ & $<0,1$ \\
\hline glyfosaat & Aardappelstoomsch. & MRL & 18,00 & 2,66 & 2,00 & 3,61 & $<0,1$ & $<0,1$ & $<0,1$ & $<0,1$ \\
\hline esfenvaleraat & Aardappelstoomsch. & Meting (dl) & 0,36 & 0,09 & 0,07 & 0,13 & 19,1 & $<0,1$ & $<0,1$ & $<0,1$ \\
\hline glyfosaat & $\begin{array}{l}\text { Stillage (maïsfermentatie } \\
\text { resten uit Zeafuelspr.) }\end{array}$ & MRL & 32,89 & 4,85 & & & 0,1 & $<0,1$ & $<0,1$ & $<0,1$ \\
\hline metsulfuron-methyl & Graanspoeling & MRL & 1,64 & 0,87 & $*$ & * & 11870,6 & 31,4 & 3,1 & 31,4 \\
\hline pirimifos-methyl & Graanspoeling & Meting & 9,94 & 1,37 & $*$ & * & 59852,4 & 41,3 & 4,1 & 41,3 \\
\hline deltamethrin & Graanspoeling & Meting (dl) & 0,66 & 0,11 & $*$ & * & 99,2 & 0,1 & $<0,1$ & 0,1 \\
\hline mancozeb & Graanspoeling & MRL & 32,89 & 2,17 & $*$ & $*$ & 322,4 & 0,1 & $<0,1$ & 0,1 \\
\hline lambda-cyhalothrin & Graanspoeling & Meting (dl) & 0,33 & 0,13 & $*$ & $*$ & 339,3 & 0,7 & 0,1 & 0,7 \\
\hline MCPA & Graanspoeling & MRL & 1,64 & 1,62 & $*$ & $*$ & 59,7 & 0,3 & $<0,1$ & 0,3 \\
\hline glyfosaat & Graanspoeling & Meting & 3,14 & 0,46 & $*$ & * & $<0,1$ & $<0,1$ & $<0,1$ & $<0,1$ \\
\hline thiofanaat-methyl & Graanspoeling & MRL & 1,64 & $<0,01$ & $*$ & $*$ & 46,1 & $<0,1$ & $<0,1$ & $<0,1$ \\
\hline pirimifos-methyl & Bloembollen & Meting (dl) & 0,86 & 0,12 & 0,07 & 0,21 & 5191,1 & 3,6 & 0,4 & 3,6 \\
\hline deltamethrin & Bloembollen & Berekening & 5,60 & 0,95 & 0,60 & 1,69 & 844,8 & 0,7 & $<0,1$ & 0,7 \\
\hline mancozeb & Bloembollen & Berekening & 431,03 & 28,40 & 17,86 & 50,25 & 4224,1 & 1,4 & 0,1 & 1,4 \\
\hline lambda-cyhalothrin & Bloembollen & Berekening & 0,86 & 0,34 & 0,21 & 0,60 & 889,3 & 1,7 & 0,2 & 1,7 \\
\hline metam-natrium & Bloembollen & Berekening & 2,16 & $<0,01$ & $<0,01$ & $<0,01$ & 768,0 & $<0,1$ & $<0,1$ & $<0,1$ \\
\hline thiofanaat-methyl & Bloembollen & Berekening & 129,31 & 0,02 & 0,01 & 0,03 & 3620,7 & $<0,1$ & $<0,1$ & $<0,1$ \\
\hline esfenvaleraat & Bloembollen & Berekening & 1,72 & 0,44 & 0,28 & 0,78 & 91,5 & 0,1 & $<0,1$ & 0,1 \\
\hline pirimifos-methyl & Waterbroei tulpen & Meting & 0,07 & 0,01 & 0,01 & 0,01 & 444,2 & 0,3 & $<0,1$ & 0,3 \\
\hline pirimifos-methyl & Bloembollenafval & Meting (dl) & 0,89 & 0,12 & 0,07 & 0,21 & 5357,4 & 3,7 & 0,4 & 3,7 \\
\hline deltamethrin & Bloembollenafval & Berekening & 5,78 & 0,98 & 0,60 & 1,69 & 871,9 & 0,7 & $<0,1$ & 0,7 \\
\hline mancozeb & Bloembollenafval & Berekening & 889,68 & 58,62 & 35,72 & 100,50 & 8718,9 & 2,9 & 0,3 & 2,9 \\
\hline lambda-cyhalothrin & Bloembollenafval & Berekening & 1,78 & 0,70 & 0,43 & 1,20 & 1835,6 & 3,6 & 0,4 & 3,6 \\
\hline metam-natrium & Bloembollenafval & Berekening & 44,48 & 0,02 & 0,01 & 0,03 & 15852,5 & $<0,1$ & $<0,1$ & $<0,1$ \\
\hline thiofanaat-methyl & Bloembollenafval & Berekening & 133,45 & 0,02 & 0,01 & 0,03 & 3736,7 & $<0,1$ & $<0,1$ & $<0,1$ \\
\hline esfenvaleraat & Bloembollenafval & Berekening & 1,78 & 0,46 & 0,28 & 0,78 & 94,5 & 0,1 & $<0,1$ & 0,1 \\
\hline
\end{tabular}

144 | wot-technical report 70 


\section{Referenties}

CBS StatLine, 2010: http://StatLine.cbs.nl/statweb/

Ctgb, 2010. Bestrijdingsmiddelendatabank

http://www.ctb.agro.nl/portal/page?_pageid=33,46731\&_dad=portal\&_schema=PORTAL

EU pesticide database - http://ec.europa.eu/sanco_pesticides

Footprint database - http://sitem.herts.ac.uk/aeru/footprint/en/

GBK, 2010. Gewasbeschermingskennisbank

Olde Venterink, H.G.M. en J.B.H.J. Linders, 1994. Normen voor de concentratie van organische microverontreinigingen in organische meststoffen: een voorstel voor hun afleiding. RIVM Rapport 679101007.

Positieve Lijst, 2010: zie Tabel horende bij punt 1, onderdeel IV van bijlage Aa, Uitvoeringsregeling Meststoffenwet.

TCB (2010). Technische commissie bodem, TCB A065: advies Covergisting

Van Dijk, T.A., J.J.M. Driessen, P.A.I. Ehlert, P.H. Hotsma, M.H.M.M. Montforts, S.F. Plessius \& O. Oenema, 2009. Protocol Beoordeling Stoffen Meststoffenwet. Versie 2.1. WOT werkdocument 167, 74 blz.

Bijlage 5.1 Shortlist van actieve stoffen verzameld uit de Excelbestanden van GBK.

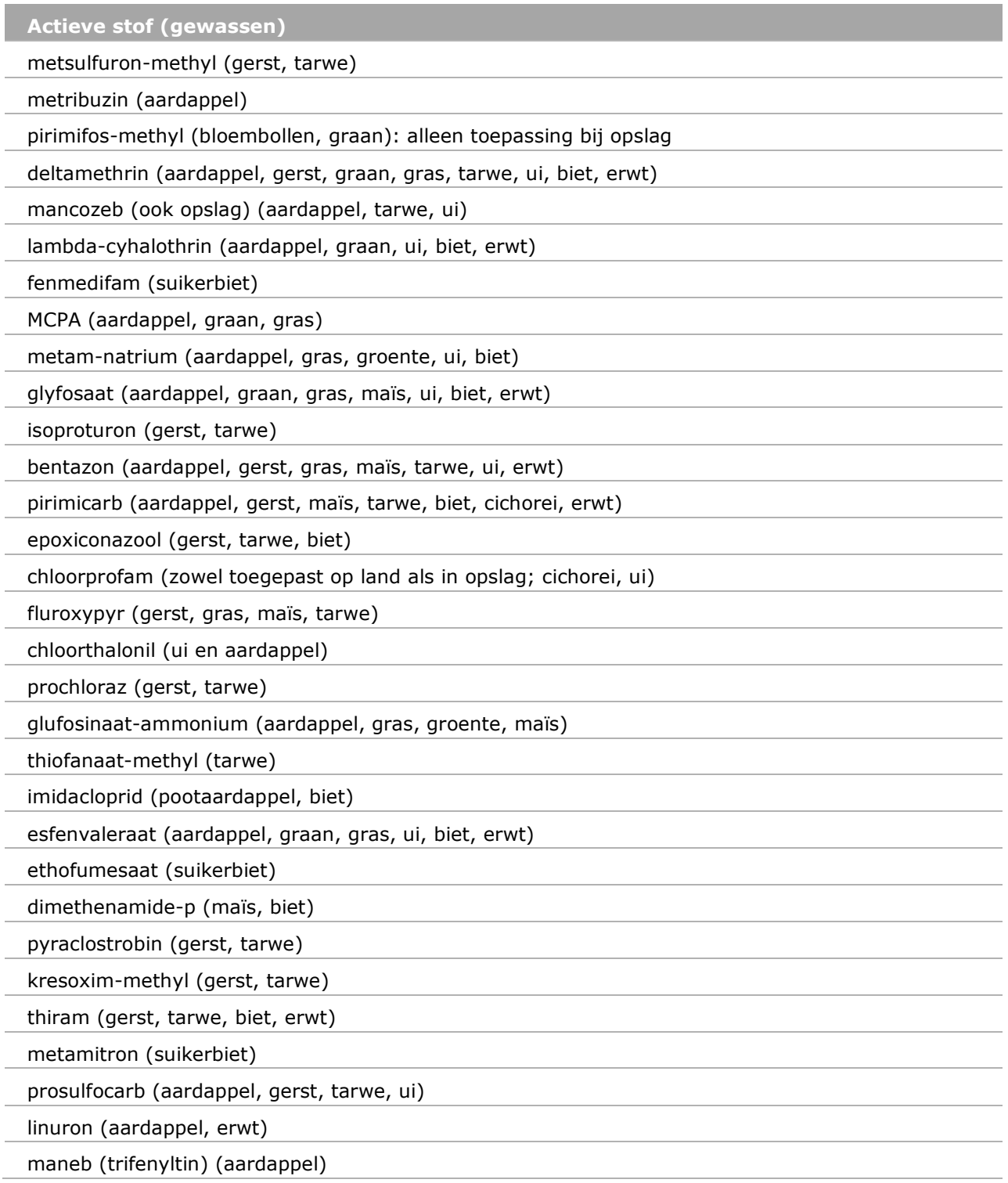


Actieve stof (gewassen)

fluazinam (aardappel, ui)

chloridazon (biet, ui)

dimethomorf (aardappel, ui)

mecoprop-P (gerst, graan, gras)

imazalil (enilconazole)

iprodion (ui, biet, erwt)

fluazifop-p-butyl (aardappel, ui, biet, cichorei, erwt)

nicosulfuron (maïs)

metiram (aardappel)

tepraloxydim (aardappel, ui, biet, erwt)

chloormequat (tarwe)

quizalofop-p-ethyl (aardappel, biet, erwt)

rimsulfuron (aardappel, maïs)

sulcotrion (maïs)

clopyralide (suikerbiet)

metaldehyde (akkerb, groente)

propamocarb-hydrochloride (aardappel)

isoxaflutool (maïs)

146 | wot-technical report 70 


\section{Bijlage 6 Toegelaten actieve stoffen bij teelt van bloembolgewassen}

Lijst met actieve stoffen die gebruikt kunnen zijn voorafgaand en tijdens de teelt van tulp, lelie en gladiool (Bron: PPO Bloembollen, Boomkwekerij en Fruit, geldend per 31-12-2010)

\begin{tabular}{|c|c|c|}
\hline Tulp & Lelie & Gladiool \\
\hline ascorbinezuur & ascorbinezuur & abamectin \\
\hline asulam & asulam & ascorbinezuur \\
\hline boscalid & azoxystrobine & asulam \\
\hline captan & boscalid & azoxystrobin \\
\hline chloorprofam & captan & boscalid \\
\hline chloorthalonil & chloorprofam & captan \\
\hline chloridazon & chloorthalonil & chloorprofam \\
\hline cycloxydim & chloridazon & chloorthalonil \\
\hline deltametrin & cycloxydim & chloridazon \\
\hline esfenfaleraat & deltametrin & cycloxydim \\
\hline etridiazol & esfenfaleraat & deltametrin \\
\hline fluazinam & ethoprofos & dimethoaat \\
\hline folpet & etridiazol & esfenfaleraat \\
\hline fosethyl-aluminium & fluazinam & ethoprofos \\
\hline glufosinaat-ammonium & fluazofop-P-butyl & etridiazol \\
\hline glyfosaat & folpet & fenmedifam \\
\hline imidacloprid & fosthiazaat & fluazinam \\
\hline iprodion & glufosinaat-ammonium & folpet \\
\hline kaliumjodide & glyfosfaat & glufosinaat-ammonium \\
\hline kaliumthiocyanaat & imidacloprid & glyfosaat \\
\hline kresoxim-methyl & iprodion & imidacloprid \\
\hline lambda-cyhalothrin & kaliumjodide & iprodion \\
\hline mancozeb & kaliumthiocyanaat & kaliumjodide \\
\hline maneb & kresoxim-methyl & kaliumthiocyanaat \\
\hline mepanipyrim & lambda-cyhalothrin & kresoxim-methyl \\
\hline metam natrium & linuron & lambda-cyhalothrin \\
\hline metamitron & mancozeb & mancozeb \\
\hline pendimethalin & maneb & maneb \\
\hline perazijnzuur & mepanipyrim & MCPA \\
\hline pirimifos-methyl & metam natrium & mepanipyrim \\
\hline prochloraz & metamitron & metam natrium \\
\hline prothioconazool & minerale olie & metamitron \\
\hline pyraclostrobin & oxamil & pendimethalin \\
\hline pyrimethanil & pendimethalin & perazijnzuur \\
\hline s-metholachloor & perazijnzuur & pirimicarb \\
\hline tebuconazool & pirimicarb & pirimifos-methyl \\
\hline tepraloxydim & pirimifos-methyl & prochloraz \\
\hline thiacloprid & prochloraz & prothioconazool \\
\hline thiofanaat methyl & prothioconazool & pyraclostrobin \\
\hline
\end{tabular}




\begin{tabular}{lll}
\hline & & \\
Tulp & Lelie & Gladiool \\
tolclofos-methyl & pymetrozine & s-metholachloor \\
\hline trifloxystrobine & pyraclostrobin & tebuconazool \\
\hline waterstofperoxide & quizalofop-p-ethyl & tepraloxydim \\
\hline & s-metholachloor & thiacloprid \\
\hline & tebuconazool & thiofanaat methyl \\
\hline & tepraloxydim & tolclofos-methyl \\
\hline & thiacloprid & trifloxystrobine \\
\hline & thiofanaat methyl & waterstofperoxide \\
\hline & tolclofos-methyl & \\
\hline trifloxystrobine & \\
\hline waterstofperoxide & \\
\hline
\end{tabular}




\section{Bijlage 7 Vlaamse lijst van afvalstoffen die in aanmerking komen voor gebruik als secundaire grondstoffen met voorwaarden}

\begin{tabular}{|c|c|c|}
\hline \multicolumn{3}{|c|}{ Gebruik en of als meststof of bodemverbeterend middel } \\
\hline BENAMING AFVALSTOF & HERKOMST EN OMSCHRIJVING & $\begin{array}{l}\text { VOORWAARDEN INZAKE } \\
\text { SAMENSTELLING EN/OF } \\
\text { GEBRUIK }\end{array}$ \\
\hline $\begin{array}{l}\text { Schuimaarde van } \\
\text { suikerfabrieken }\end{array}$ & $\begin{array}{l}\text { Suikerfabriek; product verkregen bij de } \\
\text { suikerraffinage en dat hoofdzakelijk bestaat uit } \\
\text { calciumcarbonaat, organische stof en water }\end{array}$ & artikel 4.2.1.1 \\
\hline Kalkas & $\begin{array}{l}\text { Branden van kalksteenrots; asrest die als } \\
\text { hoofdbestanddeel calciumoxide bevat en } \\
\text { eventueel calciumhydroxide en calciumcarbonaat }\end{array}$ & artikel 4.2.1.1 \\
\hline Calciumsulfaat & $\begin{array}{l}\text { Verkregen bij de fosfor- en/of citroen- } \\
\text { zuurproductie en die gehydrateerd calciumsulfaat } \\
\text { bevat }\end{array}$ & $\begin{array}{l}\text { Artikel } 4.2 .1 .1 \\
\text { gebruikscertificaat } \\
\text { verplicht }^{82}\end{array}$ \\
\hline $\begin{array}{l}\text { Afgeoogst } \\
\text { champignoncompost }\end{array}$ & $\begin{array}{l}\text { Champignonkwekerij; organische } \\
\text { voedingsbodem die overblijft na het telen van } \\
\text { champignons }\end{array}$ & artikel 4.2.1.1 \\
\hline Compost van boomschors & $\begin{array}{l}\text { Vergunde inrichting voor de compostering van } \\
\text { schorsafval dat vrijkomt bij het ontschorsen van } \\
\text { bomen }\end{array}$ & artikel 4.2.1.1 \\
\hline $\begin{array}{l}\text { Vinasse, vinasse-extract, } \\
\text { vinassekali en chicoreivinasse }\end{array}$ & $\begin{array}{l}\text { Gistfabriek; stroopachtig residu bekomen uit } \\
\text { uitgegiste melasse, extract verkregen uit vinasse } \\
\text { door toevoeging van ammonium-sulfaat of } \\
\text { bekomen tijdens de productie van inuline }\end{array}$ & artikel 4.2.1.1 \\
\hline $\begin{array}{l}\text { Vismeel, diermeel, verenmeel, } \\
\text { beendermeel, wol, vispers- } \\
\text { water, stoffen van de } \\
\text { bewerking van vellen, galaliet } \\
\text { in poeder, hoornmeel, leder- } \\
\text { meel, bloedmeel of andere toe } \\
\text { te laten stoffen van dierlijke } \\
\text { oorsprong }\end{array}$ & $\begin{array}{l}\text { Erkende of geregistreerde verwerkingsinrichting } \\
\text { voor dierlijk afval, met inbegrip van bloed }\end{array}$ & artikel 4.2.1.1 \\
\hline $\begin{array}{l}\text { Gedroogd cacao-, tabak en } \\
\text { koffieafval }\end{array}$ & $\begin{array}{l}\text { Genotmiddelenindustrie; verkregen bij de } \\
\text { verwerking van cacao- en koffiebonen en tabak } \\
\text { en de bereiding van theobromine uit cacao-afval } \\
\text { onder toevoeging van kalk }\end{array}$ & artikel 4.2.1.1 \\
\hline $\begin{array}{l}\text { Neergeslagen dubbelzout van } \\
\text { kaliumsulfaat en } \\
\text { calciumsulfaat (in geval van } \\
\text { toevoeging van een } \\
\text { magnesiumzout aangevuld } \\
\text { met "met magnesiumzout") }\end{array}$ & $\begin{array}{l}\text { Industriële citroenzuurproductie; bekomen uit } \\
\text { spoeling van citroenzuur }\end{array}$ & $\begin{array}{l}\text { Artikel } 4.2 .1 .1 \\
\text { gebruikscertificaat verplicht }\end{array}$ \\
\hline
\end{tabular}

\footnotetext{
${ }^{82}$ Een gebruikerscertificaat berust op een eenmalige analyse, een keuringsattest gebaseerd is op een integrale ketenbewaking
} 


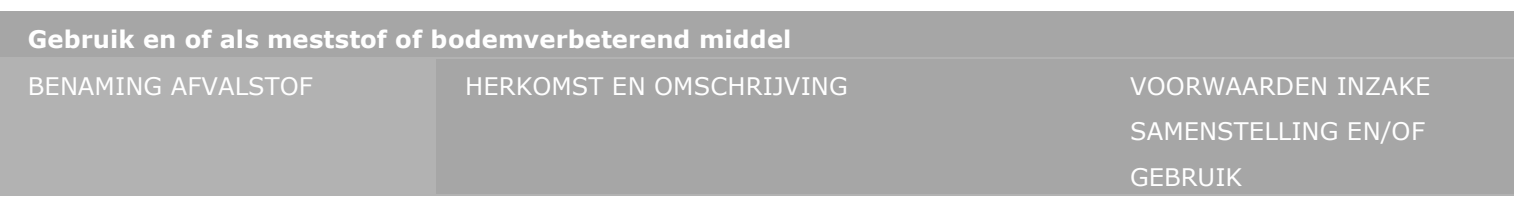

Meel van oliekoeken Winning plantaardige oliën bekomen door

Artikel 4.2.1.1 winning van olie door persing van oliehoudende zaden.

\begin{tabular}{ll}
\hline Moutscheuten & zaden. \\
\hline Behandeld zuiveringsslib & Zie artikel $1.1 .1, \S 2,52^{\circ}$ \\
\end{tabular}

Kalkhoudend slib Waterbehandeling; verkregen bij de bereiding Artikel 4.2.1.1

GFT- en groencompost
van drinkwater of proceswater uit ruwwater Artikelen 4.2.1.1 en 4.2.1.2 gebruikscertificaat verplicht Artikel 4.2.1.1 Vergunde inrichting voor de compostering of gebruikscertificaat verplicht vergisting van groenten-, fruit- en tuinafval Artikel 4.2.1.1 beschikken (GFT) met maximaal $25 \%$ organisch biologische bedrijfsafvalstoffen of van organisch afval dat oer een keuringsattest afgeleverd door de vzw vrijkomt in tuinen, plantsoenen, parken en langs bermen

VLACO (1) of onderworpen aan een gelijkaardige kwaliteitscontrole (2).

Compost of digestaat van Vergunde inrichting voor de compostering of organische of biologische vergisting van organisch-biologische Artikel 4.2.1.1 beschikken bedrijfsafvalstoffen bedrijfsafvalstoffen al dan niet in combinatie met over een keuringsattest afgeleverd door de vzw dierlijke mest

VLACO (1) of onderworpen aan een gelijkaardige kwaliteitscontrole (2)

Filterkoek Voedingsnijverheid; verkregen bij de filtratie van Artikel 4.2.1.1 levensmiddelen op anorganische filtermedia (diatomeeënaarde, perliet, bleekaarde, ...).

Gehydrolyseerd eiwit voor meststof Slib van natuursteenbewerking Filterkoek van de fermentatie Kalimoederloog

Kalimoederloog
Oplossing bevattende
ammoniumchloride
Aromaproductie; bekomen door hydrolyse van eiwitten

Bekomen door het verzagen, slijpen en polijsten Artikel 4.2.1.1 van kalkhoudende natuursteen Artikel 4.2.1.1

Artikelen 4.2.1.1 en 4.2.1.2 gebruikscertificaat verplicht regelgeving dierlijk afval Fermentatie-industrie; verkregen bij de vergisting Methionineproductie; vloeibare stof waarbij

Artikel 4.2.1.1 kalium als kaliumcarbonaat en kaliumbicarbonaat voorkomt

Glycineproductie; verkregen bij de bereiding van Artikel 4.2.1.1 het aminozuur glycine

\section{Gemalen staalslakken} Staalnijverheid; calciumsilicofosfaten Artikel 4.2.1.1 voortkomen van de behandeling van gietijzer

Gedroogde en gemalen anorganische kalkrijke voedingsresten Afkomstig van een vergunde Artikel 4.2.1.1 Vlasstof, graanstof verwerkingsinrichting van selectief ingezamelde eierschalen, schaaldieren,...

Mest Vlasindustrie, graanindustrie Artikel 4.2.1.1 Afkomstig van dieren die niet als vee worden Artikel 4.2.1.1 beschouwd volgens het mestdecreet, en niet van proefdieren

Gesteriliseerd en gedroogd Erkende of geregistreerde verwerkingsinrichting mengsel van zuiveringsslib, voor dierlijk afval, met inbegrip van bloed

\section{Artikel 4.2.1.1}

dierlijk afval en dierlijke mest

(1) Vlaamse compostorganisatie vzw.

(2) certificatie en controle uitgevoerd door een instelling die voor het betreffende materiaal over de nodige bekwaamheid beschikt. Er moeten minstens dezelfde controleprocedures en dezelfde waarborgen aanwezig zijn als bij een VLACO-keuring. De controleprocedure slaat op de interne kwaliteitscontrole (acceptatiebeleid, registratie van alle aan- en afvoer, controle van de kwaliteit) en de externe controle hierop door een erkende onafhankelijke instelling. Met dezelfde waarborgen wordt bedoeld dat de exploitant van de recuperatie-inrichting de nodige vergunningen moet bezitten waardoor verzekerd wordt dat voldaan is aan alle nodige milieuhygiënische en landbouwkundige kwaliteitsvoorschriften. 


\section{Bijlage 8 Lijst van afvalstoffen die in aanmerking komen voor hergebruik in Vlaanderen en Duitsland}

\begin{tabular}{|c|c|c|}
\hline Eural code & Omschrijving & $\begin{array}{l}\text { Aanvullende informatie (indien nodig, de } \\
\text { herkomst van het afval wordt aangegeven } \\
\text { tussen haakjes aan het begin) }\end{array}$ \\
\hline \multicolumn{3}{|c|}{$\begin{array}{l}02 \text { AFVAL VAN LANDBOUW, TUINBOUW, AQUACULTUUR, BOSBOUW, JACHT EN VISSERIJ EN DE VOEDINGSBEREIDING EN } \\
\text {-VERWERKING }\end{array}$} \\
\hline \multicolumn{3}{|c|}{$\begin{array}{l}0201 \text { Afval van landbouw, tuinbouw, aquacultuur, bosbouw, jacht en visserij en de voedingsbereiding en } \\
\text {-verwerking }\end{array}$} \\
\hline $\begin{array}{l}020103 \text { Afval van } \\
\text { plantaardige weefsels }\end{array}$ & $\begin{array}{l}\text { - resten van voedermiddelen } \\
\text { - kaf, stof van kaf en koren }\end{array}$ & $\begin{array}{l}\text { Materialen kunnen, ook als bestanddeel van een } \\
\text { mengsel, op permanent grasland worden toegediend. }\end{array}$ \\
\hline $\begin{array}{l}020106 \text { Dierlijke faeces, } \\
\text { urine en mest (inclusief } \\
\text { verteerd stro), afvalwater, } \\
\text { gescheiden ingezameld en } \\
\text { elders verwerkt }\end{array}$ & $\begin{array}{l}\text { - pluimveemest } \\
\text { - varkens- en rundveemest } \\
\text { - mest } \\
\text { - oude stro }\end{array}$ & $\begin{array}{l}\text { BioAbfV is alleen dan van toepassing indien } \\
\text { bepalingen voor dierlijke mest volgens het } \\
\text { Düngemittelrecht niet gelden. Dierlijke mest besmet } \\
\text { met een infectieziekte is uitgesloten. Materialen } \\
\text { kunnen, ook als bestanddeel van een mengsel, op } \\
\text { permanent grasland worden toegediend. }\end{array}$ \\
\hline $\begin{array}{l}02020107 \text { Afval van de } \\
\text { bosbouw }\end{array}$ & $\begin{array}{l}\text { - schors } \\
\text { - hout, houtresten }\end{array}$ & $\begin{array}{l}\text { Natuurlijke schors en ongemengde producten voor } \\
\text { verdere verwerking zijn uitgezonderd van } \\
\text { verplichtingen opgelegd door BioAbfV t.a.v. } \\
\text { verwerking en samenstellingseisen. Schors van } \\
\text { natuurlijke herkomst, onbehandeld hout of houtresten } \\
\text { van natuurlijke herkomst kunnen na verkleining als } \\
\text { grondstof bij een composteerinstallatie worden } \\
\text { gebruikt waarna gebruik op permanent grasland is } \\
\text { toegestaan. }\end{array}$ \\
\hline $\begin{array}{l}020199 \text { Niet elders } \\
\text { genoemd afval }\end{array}$ & - champost & $\begin{array}{l}\text { Afgewerkte substraat van eetbare paddestoelen. Door } \\
\text { stomen zijn schimmelculturen afgedood. }\end{array}$ \\
\hline \multicolumn{3}{|c|}{0202 Afval van de bereiding en verwerking van vlees, vis en ander voedsel van dierlijke oorsprong } \\
\hline $\begin{array}{l}020202 \text { Afval van dierlijk } \\
\text { weefsel }\end{array}$ & - resten van haar en hoorns & $\begin{array}{l}\text { Inclusief haren van runderen na een kalkbehandeling. } \\
\text { Verwerking alleen mogelijk als voldaan wordt aan } \\
\text { bepalingen die gelden voor dierlijke bijproducten en } \\
\text { het voorkomen van de verspreiding van dierziekten. }\end{array}$ \\
\hline $\begin{array}{l}020203 \text { Voor consumptie of } \\
\text { verwerking ongeschikt }\end{array}$ & - vetafval & $\begin{array}{l}\text { (Vlees- en visverwerking) } \\
\text { Verwerking alleen mogelijk als voldaan wordt aan } \\
\text { bepalingen die gelden voor dierlijke bijproducten en } \\
\text { aan bepalingen voor het voorkomen van de } \\
\text { verspreiding van dierziekten. } \\
\text { Vetresten mogen uitsluitend verwerkt worden door } \\
\text { anaërobe behandeling. Materialen mogen uitsluitend } \\
\text { na een sanitatiestap ( } 70^{\circ} \mathrm{C} \text { gedurende minimaal } 1 \\
\text { uur) op permanent grasland worden toegepast. }\end{array}$ \\
\hline
\end{tabular}

020204 Slib van afvalwaterbehandeling ter plaatse
- inhoud van vetafscheiders en reststoffen die vrijkomen door flotatie
(Vlees- en visverwerking) Bijvoorbeeld afkomstig van slachthuizen en vleesverwerkende bedrijven; vrij van andere vloeibare reststoffen.

Verwerking alleen mogelijk als voldaan wordt aan bepalingen die gelden voor dierlijke bijproducten en het voorkomen van de verspreiding van dierziekten. Vetresten en reststoffen die vrijkomen door flotatie 
mogen uitsluitend verwerkt worden door anaërobe behandeling. Materialen, ook als bestanddeel van een mengsel, mogen uitsluitend na een sanitatiestap $\left(70^{\circ} \mathrm{C}\right.$ gedurende minimaal 1 uur) op permanent grasland worden toegepast.

020299 Niet elders genoemd afval

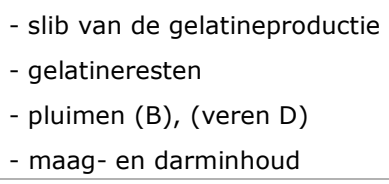

Verwerking alleen mogelijk als voldaan wordt aan bepalingen die gelden voor dierlijke bijproducten en het voorkomen van de verspreiding van dierziekten.

0203 Afval van de bereiding en verwerking van fruit, groenten, granen, spijsolie, cacao, koffie, thee en tabak, de productie van conserven, de productie van gist en gistextract en de bereiding en fermentatie van melasse

\begin{tabular}{|c|c|c|}
\hline $\begin{array}{l}020301 \text { Slib van wassen, } \\
\text { schoonmaken, schillen, } \\
\text { centrifugeren en scheiden } \\
\text { scheidingsprocessen }\end{array}$ & $\begin{array}{l}\text { - slibvormig afval van } \\
\text { voedingsmiddelen } \\
\text { - zetmeelslib }\end{array}$ & $\begin{array}{l}\text { (voedselproductie) Uitsluitend te gebruiken zonder } \\
\text { afvalwater of afvalslib van andere herkomst. } \\
\text { Materialen kunnen, ook als bestanddeel van een } \\
\text { mengsel, op permanent grasland worden toegediend. }\end{array}$ \\
\hline $\begin{array}{l}020304 \text { Voor consumptie of } \\
\text { verwerking ongeschikt } \\
\text { materiaal }\end{array}$ & $\begin{array}{l}\text { - over datum voedings- } \\
\text { middelen } \\
\text { - resten bij de fabricatie van } \\
\text { conserven } \\
\text { - over datum genotsmiddelen } \\
\text { - tabakstof, tabakgruis, } \\
\text { tabaknerven en tabakslib } \\
\text { - sigarettenresten foute } \\
\text { productiecharges van } \\
\text { sigaretten } \\
\text { - resten uit de fabricatie van } \\
\text { koffie, thee en cacao } \\
\text { - resten van oliehoudende } \\
\text { zaden }\end{array}$ & $\begin{array}{l}\text { (voedselproductie) } \\
\text { Verwerking alleen mogelijk als voldaan wordt aan } \\
\text { bepalingen die gelden voor dierlijke bijproducten en } \\
\text { het voorkomen van de verspreiding van dierziekten. }\end{array}$ \\
\hline
\end{tabular}

020305 Slib van de afvalwaterbehandeling ter plaatse

020399 Niet elders genoemd afval
- slib van het fabriceren van eetbare vetten - slib van het fabriceren van spijsolie

- ontoliede bleekaarde

- kruidenresten

- melasseresten

- resten uit de productie van

aardappel-, maïs- of

rijstzetmeel

\section{(voedselproductie)}

Slib van de productie van spijsvetten en spijsoliën (vet en olie voor levensmiddelen), reststoffen van melasse en reststof van de productie van zetmeel van aardappel, maïs of rijst mogen ook als bestanddeel van een mengsel op permanent grasland worden uitgereden. Slib van spijsvet- en spijsolieproductie mogen uitsluitend door middel van anaërobe behandeling worden verwerkt.

0204 Afval van de suikerverwerking
020402 Afgekeurd
- resten van carbonatie
(Verwerking van suikerbieten)
calciumcarbonaat $(=$ Deze materialen mogen aan bioafval worden schuimaarde) toegediend welk op permanent grasland mag worden toegediend.

\begin{tabular}{ll}
\hline 020403 Slib van de afvalwaterbehandeling ter plaatse & Elders opgenomen in de Duitse lijst \\
\hline $\begin{array}{l}0205 \text { Afval van de } \\
\text { zuivelindustrie }\end{array}$ & \\
\hline 020501 Voor consumptie of $\quad$ - over datum levensmiddelen & $\begin{array}{l}\text { (verwerking van melk) } \\
\text { verwerking ongeschikt }\end{array}$ \\
$\begin{array}{l}\text { Verwerking alleen mogelijk als voldaan wordt aan } \\
\text { materiaal }\end{array}$ & $\begin{array}{l}\text { bepalingen die gelden voor dierlijke bijproducten en } \\
\text { het voorkomen van de verspreiding van dierziekten. }\end{array}$ \\
& Materialen kunnen, ook als bestanddeel van een \\
& mengsel, op permanent grasland worden toegediend. \\
\hline
\end{tabular}


Eural code Omschrijving Aanvullende informatie (indien nodig, de

herkomst van het afval wordt aangegeven

tussen haakjes aan het begin)

020502 Slib van de afvalwaterbehandeling ter plaatse

020599 Niet elders - wei (afval van verwerking van melk)

genoemd afval

Verwerking alleen mogelijk als voldaan wordt aan bepalingen die gelden voor dierlijke bijproducten en het voorkomen van de verspreiding van dierziekten.

Materialen kunnen, ook als bestanddeel van een mengsel, op permanent grasland worden toegediend.

0206 Afval van bakkerijen en de banketbakkersindustrie

$\begin{array}{ll}020601 \text { Voor consumptie of } & \text { - over datum } \\ \text { verwerking ongeschikt } & \text { - deegafval } \\ \text { materiaal } & \end{array}$

(Bakkerij- en zoetwarenindustrie)

materiaal

Verwerking alleen mogelijk als voldaan wordt aan bepalingen die gelden voor dierlijke bijproducten en het voorkomen van de verspreiding van dierziekten.

0207 Afval van de productie van alcoholische en niet-alcoholische dranken (exclusief koffie, thee en cacao)

\begin{tabular}{|c|c|}
\hline $\begin{array}{l}020701 \text { Afval van wassen, } \\
\text { schoonmaken en } \\
\text { mechanische bewerking van } \\
\text { de grondstoffen }\end{array}$ & $\begin{array}{l}\text { - gebruikte filters- en } \\
\text { absorptiematerialen } \\
\text { (kiezelgoer), actieve aarde, } \\
\text { actieve kool }\end{array}$ \\
\hline $\begin{array}{l}020702 \text { Afval van de } \\
\text { destillatie van alcoholische } \\
\text { dranken }\end{array}$ & $\begin{array}{l}\text { - fruit-, graan- en aardappel- } \\
\text { resten } \\
\text { - afval van destillatie (alcohol } \\
\text { destillatie) }\end{array}$ \\
\hline
\end{tabular}

020704 Voor consumptie of

verwerking ongeschikt

(Productie van alcoholische en niet- alcoholhoudende dranken)

Kieselgoer mag niet in gedroogde toestand uitgereden worden en dient direct daarop in de bodem ingewerkt te worden.

materiaal

Materialen kunnen, ook als bestanddeel van een

mengsel, op permanent grasland worden toegediend.

\section{Slib van}

afvalwaterbehandeling door

het eigen bedrijf 020305

020403

020502

020603

020705

020799 Niet elders

genoemd afval

\author{
- draf, kiemen en stof van \\ mout \\ - draf en slib uit \\ bierbrouwerijen \\ - slib van wijnbereiding \\ - slib van brouwerijen \\ - droesem en moer van wijn \\ (perskoek) \\ - gist en gistgelijkende \\ reststoffen
}

(Drankindustrie) bijvoorbeeld over-datum vruchtensap

Materialen kunnen, ook als bestanddeel van een mengsel, op permanent grasland worden toegediend. (Voedings- en genotsmiddelenindustrie) Toepassing alleen dan mits geen menging met afvalwater of slib mogelijk buiten het specifieke productieproces plaats heeft gevonden.

Materialen kunnen, ook als bestanddeel van een mengsel, op permanent grasland worden toegediend.

(Productie van alcoholische en niet-alcoholische dranken).

Met uitzondering van perskoek van druiven mogen andere materialen, ook als bestanddeel van een mengsel, op permanent grasland worden toegediend.

03 Afval van de houtverwerking en de productie van panelen en meubelen alsmede pulp, papier en karton

0301 Afval van de houtverwerking en de productie van panelen en meubelen

030101 Schors- en $\quad$ - schors
kurkafval (houtbe- en verwerking)

Gescheiden verzamelde boomschors, met uitzondering van bomen en struiken langs straten, zijn na paragraaf 10 aangewezen behandelingsmethoden en onderzoekverplichtingen hier opgenomen. Boomschors van bomen en struiken langs straten mogen slechts dan in een bewerkingsproces opgenomen worden als door onderzoek vastgesteld is dat de gehalten aan zware metalen niet normoverschrijdend zijn. Natuurlijke 
onbehandelde materialen mogen ook als bestanddeel van een mengsel op permanent grasland worden toegediend.

$\begin{array}{ll}030105 \text { Niet onder } 0301 & \text { - zaagsel en schaafsel } \\ 04 \text { vallend zaagsel, } & \text { - houtwol }\end{array}$
schaafsel, spaanders, hout, spaanplaat en fineer
(Houtbe- en verwerking, celstof- en meubelproductie)

Zaagsel, schaafsel, spaanders en houtwol uitsluitend afkomstig van onbehandeld hout. Zaagsel, schaafsel en spaanders uit natuurlijk onbehandeld hout mogen als grondstof bij compostering worden toegepast en vervolgens op permanent grasland worden uitgereden.

04 Afval van de leer-, bont- en textielindustrie 0402 Afval van de textielindustrie

$\begin{array}{ll}040221 \text { Afval van } & \text { - cellulose vezelafval } \\ \text { onverwerkte textielvezels } & \text { - afval van plantaardig } \\ & \text { weefsel } \\ & \text { - wolafval }\end{array}$

07 Afval van organische chemische processen

0705 Afval van BFLG van farmaceutische producten

070514 Niet onder $0705 \quad$ - perskoek van Mycelium van schimmel afkomstig van
13 vallende vaste geneeskrachtige gewassen afvalstoffen - mycelium - resten van schimmelsubstraat - afval van eiwitten

\section{(Textielindustrie)}

Stof van wol en korte wolvezels mogen uitsluitend worden gebruikt voorzover dit niet indruist tegen bepalingen voor de overdracht van dierziekten. geneesmiddelenproductie is slechts na individuele toetsing toepasbaar en als deze resten van geneesmiddelenproductie geen resten van geneesmiddelen bevatten.

19 Afval van installaties voor afvalbeheer, off-site waterzuiveringsinstallaties en de bereiding van voor menselijke consumptie bestemd water en water voor industrieel gebruik

1909 Afval van de bereiding van voor menselijke consumptie bestemd water en water voor industrieel gebruik

$\begin{array}{lll}190901 \text { Vast afval van } & \text { - resten van het afdreggen, } & \text { (Drinkwaterproductie en onderhoud waterlopen) } \\ \text { primaire filtratie en } & \text { maaien en harken } & \text { Alleen maaisel kan worden gebruikt. }\end{array}$

roostergoed

190903 Onthardingsslib - slib van waterontharding

(Waterbereiding)

Materialen mogen aan bioafval worden toegediend,

dat op permanent grasland mag worden uitgereden.

20 Stedelijk afval (huishoudelijk afval en soortgelijk bedrijfsafval, industrieel afval en afval van instellingen) inclusief gescheiden ingezamelde fracties.

2001 Gescheiden ingezamelde fracties (exclusief 15.01)

200101 Papier en karton - oud papier

Slechts in kleine hoeveelheden (ca. 10\%) aan gescheiden verzamelde bioafval toe te voegen of bij compostering te gebruiken. Gebruik van hoogglans papier en behangresten is verboden.

200108 Biologisch $\quad$ - keuken- en restaurantafval
afbreekbaar keuken- en
kantineafval

200108 Biologisch

kantineafval

200125 Spijsolie en vetten
Afval van kantines en grootkeukens volgt de Duitse verordening voorzover beantwoord wordt aan de bepalingen van de verordening voor dierlijke bijproducten. Materialen, ook als bestanddeel van een mengsel, mogen uitsluitend na een sanitatiestap $\left(70^{\circ} \mathrm{C}\right.$ gedurende minimaal 1 uur) op permanent grasland worden toegepast.

Afval van kantines en grootkeukens kunnen gebruikt worden mits beantwoord wordt aan de Duitse verordening en aan de verordening voor dierlijke bijproducten. Materialen mogen uitsluitend anaëroob bewerkt worden. Materialen, ook als bestanddeel van een mengsel, mogen uitsluitend na een sanitatiestap 


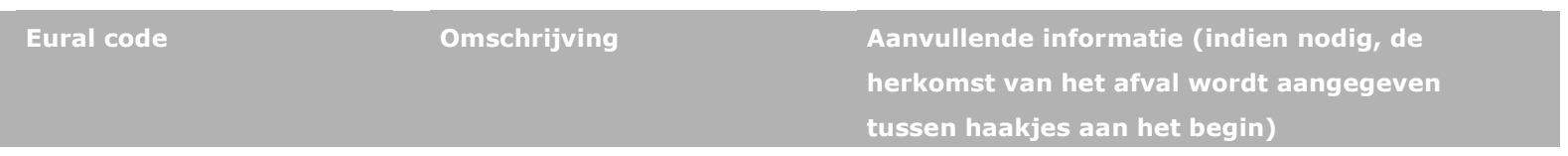

( $70^{\circ} \mathrm{C}$ gedurende minimaal 1 uur) op permanent grasland worden toegepast.

2002 Tuin- en plantsoenafval (inclusief afval van

begraafplaatsen)

200201 Biologisch - tuin- en plantsoen afval, Gescheiden verzamelde materialen met uitzondering

afbreekbaar afval plantaardig afval van

van groenafval en snoeisel van struiken van

onderhoud van het landelijk

straatkanten en locaties met industrie zijn vrijgesteld

gebied, afval van dunnen van

bossen en kreupelhout,

van de bepalingen van paragraaf 10 . Groenafval en

plantaardige drijflagen uit

snoeisel van struiken van straatkanten en

watergangen

plantaardige drijflagen uit watergangen dienen

kunnen alleen dan verwerkt worden als de

samenstellingseisen voor gehalten aan zware metalen

niet overschreden worden. Materialen kunnen, ook als

bestanddeel van een mengsel, op permanent grasland

worden toegediend.

2003 Overig stedelijk afval

200301 Gemengd stedelijk

- huisafval (afzonderlijk

(Huishoudelijk afval)

afval afgehaald bioafval)

In het bijzonder gescheiden afval van huishoudens en klein bedrijf

200302 Marktafval _ - marktafval

Voor verwerking is uitsluitend gescheiden

ingezamelde biologisch afbreekbare fractie geschikt.

Verwerking is uitsluitend toegestaan indien voldaan

wordt aan bepalingen voor dierlijke bijproducten en

bepalingen ter voorkoming van verspreiding van

dierziekten. Gescheiden ingezameld materiaal, ook als

bestanddeel van een mengsel, mag op permanent

grasland worden uitgereden.

\begin{tabular}{|c|c|c|}
\hline * & $\begin{array}{l}\text { - modder en heilaarde } \\
\text { (afkomstig van kuuroorden) }\end{array}$ & $\begin{array}{l}\text { Materialen kunnen, ook als bestanddeel van een } \\
\text { mengsel, op permanent grasland worden uitgereden. }\end{array}$ \\
\hline$*$ & $\begin{array}{l}\text { - biologisch afbreekbare } \\
\text { producten uit hernieuwbare } \\
\text { grondstoffen evenals afval uit } \\
\text { het be- en verwerkingsproces }\end{array}$ & $\begin{array}{l}\text { Afbreekbaarheid moet worden aangetoond op basis } \\
\text { van een technische norm. }\end{array}$ \\
\hline$*$ & - eierschalen & $\begin{array}{l}\text { Verwerking is uitsluitend toegestaan voorzover } \\
\text { beantwoord wordt aan bepalingen van de verordening } \\
\text { voor dierlijke bijproducten en bepalingen ter } \\
\text { voorkoming van de verspreiding van dierziekten. }\end{array}$ \\
\hline \multicolumn{3}{|c|}{ Minerale afvalstoffen, aanvul- toeslagstoffen } \\
\hline $\begin{array}{l}020402 \text { niet verplicht } \\
\text { gespecificeerd } \\
\text { calciumcarbonaatslib }\end{array}$ & - carbonatatieslib & $\begin{array}{l}\text { (Suikerbietenverwerking) } \\
\text { Materialen mogen aan bioafval worden toegediend, } \\
\text { dat op permanent grasland mag worden uitgereden. }\end{array}$ \\
\hline 190903 kalkonthardingsslib & $\begin{array}{l}\text { - Kalkslib van } \\
\text { waterontharding }\end{array}$ & $\begin{array}{l}\text { ((drink)waterbereiding) } \\
\text { Materialen mogen aan bioafval worden toegediend, } \\
\text { dat op permanent grasland mag worden uitgereden. }\end{array}$ \\
\hline * & $\begin{array}{l}\text { - kalk } \\
\text { - bentoniet } \\
\text { - stof en poeder van } \\
\text { gesteente, zand } \\
\text { - klei }\end{array}$ & $\begin{array}{l}\text { Materialen mogen aan bioafval worden toegediend, } \\
\text { dat op permanent grasland mag worden uitgereden. }\end{array}$ \\
\hline
\end{tabular}

Na oplevering van de definitieve studie maar voor het opheffen van het embargo door het ministerie van Economische Zaken, werd in Vlaarderen VLACO vervangen door VLAREMA. De lijst met secundaire grondstoffen werd daarbij aangepast. Deze aanpassingen zijn niet verwerkt in dit document. 


\section{Verschenen documenten in de reeks Technical reports van de Wettelijke Onderzoekstaken Natuur}

\& Milieu

WOt-technical reports zijn verkrijgbaar bij het secretariaat van Unit Wettelijke Onderzoekstaken Natuur \& Milieu te Wageningen. T 0317 - 4854 71; E info.wnm@wur.nl

WOt-technical reports zijn ook te downloaden via de website www.wageningenUR.nl/wotnatuurenmilieu

1 Arets, E.J.M.M., K.W. van der Hoek, H. Kramer, P.J. Kuikman \& J.-P. Lesschen (2013). Greenhouse gas reporting of the LULUCF sector for the UNFCCC and Kyoto Protocol. Background to the Dutch NIR 2013.

2 Kleunen, A. van, M. van Roomen, L. van den Bremer, A.J.J. Lemaire, J-W. Vergeer \& E. van Winden (2014). Ecologische gegevens van vogels voor Standaard Gegevensformulieren Vogelrichtlijngebieden.

3 Bruggen, C. van, A. Bannink, C.M. Groenestein, B.J. de Haan, J.F.M. Huijsmans, H.H. Luesink, S.M. van der Sluis, G.L. Velthof \& J. Vonk (2014). Emissies naar lucht uit de landbouw in 2012 Berekeningen van ammoniak, stikstofoxide, lachgas, methaan en fijn stof met het model NEMA

4 Verburg, R.W., T. Selnes \& M.J. Bogaardt (2014). Van denken naar doen; ecosysteemdiensten in de praktijk. Case studies uit Nederland, Vlaanderen en het Verenigd Koninkrijk.

5 Velthof, G.L. \& O. Oenema (2014). Commissie van Deskundigen Meststoffenwet. Taken en werkwijze; versie 2014

6 Berg, J. van den, V.J. Ingram, L.O. Judge \& E.J.M.M. Arets (2014). Integrating ecosystem services into tropical commodity chains- cocoa, soy and palm oil; Dutch policy options from an innovation system approach

7 Knegt de, B., T. van der Meij, S. Hennekens, J.A.M. Janssen \& W. Wamelink (2014). Status en trend van structuur- en functiekenmerken van Natura 2000- habitattypen op basis van het Landelijke Meetnet Flora (LMF) en de Landelijke Vegetatie Databank (LVD). Achtergronddocument voor de Artikel 17rapportage.

8 Janssen, J.A.M., E.J. Weeda, P.C. Schipper, R.J. Bijlsma, J.H.J. Schaminée, G.H.P. Arts, C.M. Deerenberg, O.G. Bos \& R.G. Jak (2014). Habitattypen in Natura 2000-gebieden. Beoordeling van oppervlakte representativiteit en behoudsstatus in de Standard Data Forms (SDFs)

9 Ottburg, F.G.W.A., J.A.M. Janssen (2014). Habitatrichtlijnsoorten in Natura 2000-gebieden. Beoordeling van populatie, leefgebied en isolatie in de Standard Data Forms (SDFs)

10 Arets, E.J.M.M. \& F.R. Veeneklaas (2014). Costs and benefits of a more sustainable production of tropical timber.

11 Vader, J. \& M.J. Bogaardt (2014). Natuurverkenning 2 jaar later; Over gebruik en doorwerking van Natuurverkenning 2010-2040.

12 Smits, M.J.W. \& C.M. van der Heide (2014). Hoe en waarom bedrijven bijdragen aan behoud van ecosysteemdiensten; en hoe de overheid dergelijke bijdragen kan stimuleren.

13 Knegt, B. de (ed.) (2014). Graadmeter Diensten van Natuur, Vraag, aanbod, gebruik en trend van goederen en diensten uit ecosystemen in Nederland.

14 Beltman, W.H.J., M.M.S. Ter Horst, P.I. Adriaanse, A. de Jong \& J. Deneer (2014). FOCUS TOXSWA manual 4.4.2; User's Guide version 4

15 Adriaanse, P.I., W.H.J. Beltman \& F. Van den Berg (2014). Metabolite formation in water and in sediment in the TOXSWA model. Theory and procedure for the upstream catchment of FOCUS streams.

16 Groenestein, K., C. van Bruggen en H. Luesink (2014) Harmonisatie diercategorieën
17 Kistenkas, F.H. (2014). Juridische aspecten van gebiedsgericht natuurbeleid (Natura 2000)

18 Koeijer, T.J. de, H.H. Luesink \& C.H.G. Daatselaar (2014). Synthese monitoring mestmarkt 2006 - 2012.

19 Schmidt, A.M., A. van Kleunen, L. Soldaat \& R. Bink (2014) Rapportages op grond van de Europese Vogelrichtlijn en Habitatrichtlijn. Evaluatie rapportageperiode 2007-2012 en aanbevelingen voor de periode 2013-2018

20 Fey F.E., N.M.A.J. Dankers, A. Meijboom, P.W. van Leeuwen, M. de Jong, E.M. Dijkman \& J.S.M. Cremer (2014). Ontwikkeling van enkele mosselbanken in de Nederlandse Waddenzee, situatie 2013.

21 Hendriks, C.M.A., D.A. Kamphorst en R.A.M. Schrijver (2014) Motieven van actoren voor verdere verduurzaming in de houtketen

22 Selnes, T.A. and D.A. Kamphorst (2014). International governance of biodiversity; searching for renewal

23 Dirkx, G.H.P, E. den Belder, I.M. Bouwma, A.L. Gerritsen, C.M.A Hendriks, D.J. van der Hoek, M. van Oorschot \& B.I. de Vos (2014). Achtergrondrapport bij beleidsstudie Natuurlijk kapitaal: toestand, trends en perspectief; Verantwoording casestudies

24 Wamelink, G.W.W., M. Van Adrichem, R. Jochem \& R.M.A. Wegman (2014). Aanpassing van het Model for Nature Policy (MNP) aan de typologie van het Subsidiestelsel Natuur en Landschap (SNL); Fase 1

25 Vos, C.C., C.J. Grashof-Bokdam \& P.F.M. Opdam (2014). Biodiversity and ecosystem services: does species diversity enhance effectiveness and reliability? A systematic literature review.

26 Arets, E.J.M.M., G.M. Hengeveld, J.P. Lesschen, H. Kramer, P.J. Kuikman \& J.W.H. van der Kolk (2014). Greenhouse gas reporting of the LULUCF sector for the UNFCCC and Kyoto Protocol. Background to the Dutch NIR 2014.

27 Roller, te J.A., F. van den Berg, P.I. Adriaanse, A. de Jong \& W.H.J. Beltman (2014). Surface WAter Scenario Help (SWASH) version 5.3. technical description

28 Schuiling, C., A.M. Schmidt \& M. Boss (2014). Beschermde gebiedenregister; Technische documentatie

29 Goossen, C.M., M.A. Kiers (2015). Mass mapping; State of the art en nieuwe ideeën om bezoekersaantallen in natuurgebieden te meten

30 Hennekens, S.M, M. Boss en A.M. Schmidt (2014). Landelijke Vegetatie Databank; Technische documentatie

31 Bijlsma, R.J., A. van Kleunen \& R. Pouwels (2014). Structuur- en functiekenmerken van leefgebieden van Vogelrichtlijn- en Habitatrichtlijnsoorten; Een concept en bouwstenen om leefgebieden op landelijk niveau en gebiedsniveau te beoordelen

32 Commissie Deskundigen Meststoffenwet (2015). Nut en risico's van covergisting. Syntheserapport.

33 Bijlsma, R.J. \& J.A.M. Janssen (2014). Structuur en functie van habitattypen; Onderdeel van de documentatie van de Habitatrichtlijn artikel 17-rapportage 2013

34 Fey F.E., N.M.J.A. Dankers, A. Meijboom, P.W. van Leeuwen, J. Cuperus, B.E. van der Weide, M. de Jong, E.M. Dijkman \& J.S.M. Cremer (2014). Ecologische ontwikkeling binnen een voor menselijke activiteiten gesloten gebied in de Nederlandse 
Waddenzee; Tussenrapportage achtste jaar na sluiting (najaar 2013).

35 Kuindersma, W., F.G. Boonstra, R.A. Arnouts, R. Folkert, R.J. Fontein, A. van Hinsberg \& D.A. Kamphorst (2015). Vernieuwingen in het provinciaal natuurbeleid; Vooronderzoek voor de evaluatie van het Natuurpact.

36 Berg van den, F., W.H.J. Beltman, P.I. Adriaanse, A. de Jong 8 J.A. te Roller (2015). SWASH Manual 5.3. User's Guide vs 5

37 Brouwer, F.M., A.B. Smit \& R.W. Verburg (2015). Economische prikkels voor vergroening in de landbouw

38 Verburg, R.W., R. Michels, L.F. Puister (2015). Aanpassing Instrumentarium Kosten Natuurbeleid (IKN) aan de typologie van het Subsidiestelsel Natuur en Landschap (SNL)

39 Commissie Deskundigen Meststoffenwet (2015). Actualisering methodiek en protocol om de fosfaattoestand van de bodem vast te stellen

40 Gies, T.J.A., J. van Os, R.A. Smidt, H.S.D. Naeff \& E.C. Vos (2015). Geografisch Informatiesysteem Agrarische Bedrijven (GIAB); Gebruikershandleiding 2010.

41 Kramer, H., J. Clement (2015). Basiskaart Natuur 2013. Een landsdekkend basisbestand voor de terrestrische natuur in Nederland

42 Kamphorst, D.A., T.A. Selnes, W. Nieuwenhuizen (2015) Vermaatschappelijking van natuurbeleid. Een verkennend onderzoek bij drie provincies

43 Commissie Deskundige Meststoffenwet (2015). Advies 'Mestverwerkingspercentages 2016

44 Meeuwsen, H.A.M. \& R. Jochem (2015). Openheid van het landschap; Berekeningen met het model ViewScape

45 Groenestein, C.M., J. de Wit, C. van Bruggen \& O. Oenema (2015). Stikstof- en fosfaatexcretie van gangbaar en biologisch gehouden landbouwhuisdieren. Herziening excretieforfaits Meststoffenwet 2015

46 Bruggen, C. van, A. Bannink, C.M. Groenestein, J.F.M. Huijsmans, H.H. Luesink, S.M. van der Sluis, G.L. Velthof \& J. Vonk (2015). Emissies naar lucht uit de landbouw, 1990-2013. Berekeningen van ammoniak, stikstofoxide, lachgas, methaan en fijn stof met het model NEMA.

47 Boonstra, F.G. \& A.L. Gerritsen (2015). Systeemverantwoordelijkheid in het natuurbeleid; Input voor agendavorming van de Balans van de Leefomgeving 2014

48 Overbeek, M.M.M., M-J. Bogaardt \& J.C. Dagevos (2015). Intermediairs die bijdragen van burgers en bedrijven aan natuur en landschap mobiliseren.

49 Os, J. van, R.A.M. Schrijver \& M.E.A. Broekmeyer (2015). Kan het Natuurbeleid tegen een stootje? Enkele botsproeven van de herijkte Ecologische Hoofdstructuur.

50 Hennekens, S.M., J.M. Hendriks, W.A. Ozinga, J.H.J. Schaminée \& L. Santini (2015). BioScore 2 - Plants \& Mammals. Background and pre-processing of distribution data

51 Koffijberg K., P. de Boer, F. Hustings, A. van Kleunen, K. Oosterbeek \& J.S.M. Cremer (2015). Broedsucces van kustbroedvogels in de Waddenzee in 2011-2013.

52 Arets, E.J.M.M., J.W.H van der Kolk, G.M. Hengeveld, J.P. Lesschen, H. Kramer, P.J. Kuikman \& M.J. Schelhaas (2015). Greenhouse gas reporting of the LULUCF sector in the Netherlands. Methodological background.

53 Vonk, J., A. Bannink, C. van Bruggen, C.M. Groenestein, J.F.M. Huijsmans, J.W.H. van der Kolk, H.H. Luesink, S.V. Oude Voshaar, S.M. van der Sluis \& G.L. Velthof (2016). Methodology for estimating emissions from agriculture in the Netherlands. Calculations of $\mathrm{CH}_{4}, \mathrm{NH}_{3}, \mathrm{~N}_{2} \mathrm{O}, \mathrm{NO}_{\mathrm{x}}, \mathrm{PM}_{10}, \mathrm{PM}_{2.5}$ and $\mathrm{CO}_{2}$ with the National Emission Model for Agriculture (NEMA)
54 Groenestein, K. \& J. Mosquera (2015). Evaluatie van methaanemissieberekeningen en -metingen in de veehouderij.

55 Schmidt, A.M. \& A.S. Adams (2015). Documentatie Habitatrichtlijn-rapportage artikel 17, 2007-2012

56 Schippers, P., A.M. Schmidt, A.L. van Kleunen \& L. van den Bremer (2015). Standard Data Form Natura 2000; bepaling van de belangrijkste drukfactoren in Natura 2000-gebieden.

57 Fey F.E., N.M.A.J. Dankers, A. Meijboom, C. Sonneveld, J.P. Verdaat, A.G. Bakker, E.M. Dijkman \& J.S.M. Cremer (2015). Ontwikkeling van enkele mosselbanken in de Nederlandse Waddenzee, situatie 2014

58 Blaeij, A.T. de, R. Michels, R.W. Verburg \& W.H.G.J. Hennen (2015). Recreatiemodule in Instrumentarium Kosten Natuurbeleid (IKN); Bepaling van de recreatiekosten

59 Bakker, E. de, H. Dagevos, R.J. Fontein \& H.J. Agricola (2015). De potentie van co-creatie voor natuurbeleid. Een conceptuele en empirische verkenning.

60 Bouwma, I.M., A.L. Gerritsen, D.A. Kamphorst \& F.H. Kistenkas (2015). Policy instruments and modes of governance in environmental policies of the European Union; Past, present and future

61 F. van den Berg, A. Tiktak, J.J.T.I. Boesten \& A.M.A. van der Linden (2016). PEARL model for pesticide behaviour and emissions in soil-plant systems; Description of processes

62 Kuiters, A.T., G.A. de Groot, D.R. Lammertsma, H.A.H. Jansman \& J. Bovenschen (2016). Genetische monitoring van de Nederlandse otterpopulatie; Ontwikkeling van populatieomvang en genetische status 2014/2015

63 Smits, M.J.W., C.M. van der Heide, H. Dagevos, T. Selnes \& C.M. Goossen (2016). Natuurinclusief ondernemen: van koplopers naar mainstreaming?

64 Pouwels, P. , M. van Eupen, M.H.C. van Adrichem, B. de Knegt \& J.G.M. van der Greft (2016). MetaNatuurplanner v2.0. Status $A$

65 Broekmeyer, M.E.A. \& M.E. Sanders (2016). Natuurwetgeving en het omgevingsrecht. Achtergrond-document bij Balans van de Leefomgeving, 2014

66 Os van, J. H.S.D. Naeff \& L.J.J. Jeurissen (2016).Geografisch informatiesysteem voor de emissieregistratie van landbouwbedrijven; GIABplus-bestand 2013 - Status $A$

67 Ingram, V.J., L.O. Judge, M. Luskova, S. van Berkum \& J. van den Berg (2016). Upscaling sustainability initiatives in international commodity chains; Examples from cocoa, coffee and soy value chains in the Netherlands.

68 Duin van W.E., H. Jongerius, A. Nicolai, J.J. Jongsma, A. Hendriks \& C. Sonneveld (2016). Friese en Groninger kwelderwerken: Monitoring en beheer 1960-2014.

69 Ehlert, P.A.I., T.A. van Dijk \& O. Oenema (2016). Opname van struviet als categorie in het Uitvoeringsbes/uit Meststoffenwet. Advies.

70 Ehlert, P.A.I., H.J. van Wijnen, J. Struijs, T.A. van Dijk, L. van Schöll, L.R.M. de Poorter (2016). Risicobeoordeling van contaminanten in afval- en reststoffen bestemd voor gebruik als covergistingsmateriaal

71 Commissie Deskundigen Meststoffenwet (2016). Protocol beoordeling stoffen Meststoffenwet. Versie 3.2 


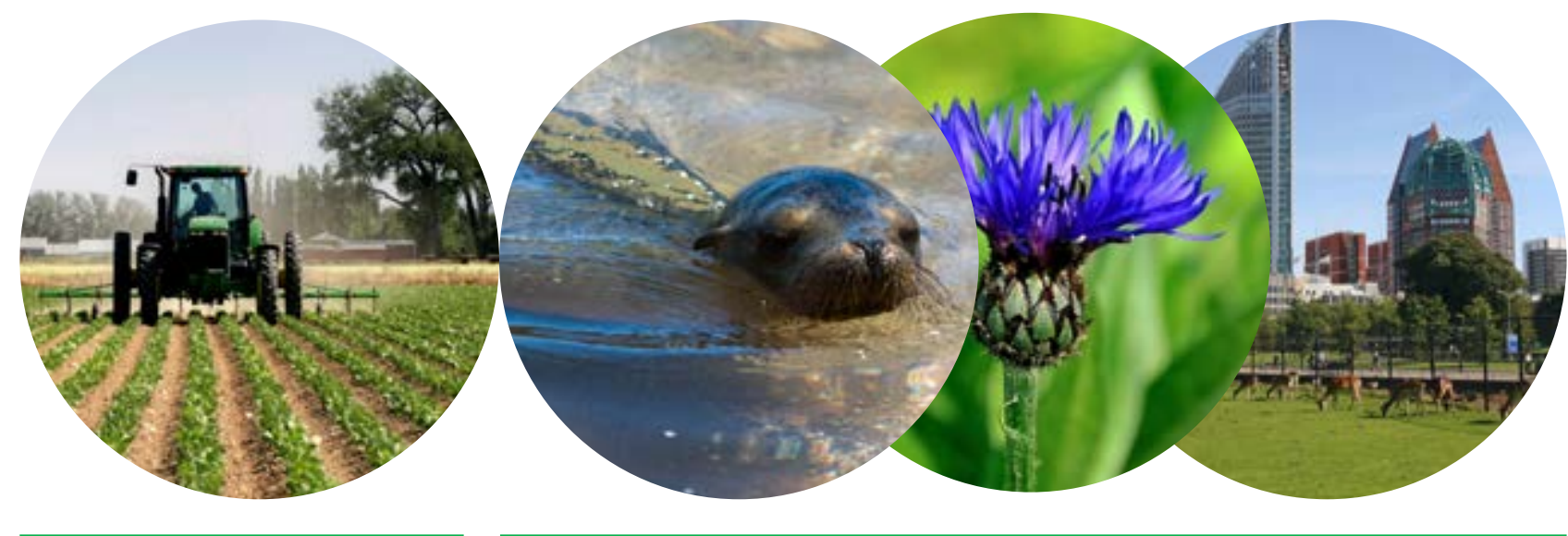

Thema Agromilieu

Wettelijke Onderzoekstaken Natuur \& Milieu

Postbus 47

6700 AA Wageningen

T (0317) 485471

E info.wnm@wur.nl

ISSN 2352-2739
De missie van Wageningen University \& Research is 'To explore the potential of nature to improve the quality of life'. Binnen Wageningen University \& Research bundelen 9 gespecialiseerde onderzoeksinstituten van Stichting Wageningen Research en Wageningen University hun krachten om bij te dragen aan de oplossing van belangrijke vragen in het domein van gezonde voeding en leefomgeving. Met ongeveer 30 vestigingen, 5.000 medewerkers en 10.000 studenten behoort Wageningen University \& Research wereldwijd tot de aansprekende kennisinstellingen binnen haar domein. De integrale benadering van de vraagstukken en de samenwerking tussen verschillende disciplines vormen het hart van de unieke Wageningen aanpak. 